\title{
O AGRONEGÓCIO NAS MACRORREGIÕES BRASILEIRAS: 1985 A 1995
}

\author{
JoSÉ LUIZ PARRÉ
}

Engenheiro Agrônomo

Orientador: Prof. Dr. JOAQUIM JOSÉ MARTINS GUILHOTO

Tese apresentada à Escola Superior de Agricultura "Luiz de Queiroz", Universidade de São Paulo, para obtenção do título de Doutor em Ciências, Área de Concentração: Economia Aplicada

PIRACICABA

Estado de São Paulo - Brasil

Janeiro - 2000 


\title{
Dados Internacionais de catalogação na Publicação (CIP) DIVISÃo DE BIBLIOTECA E DOCUMENTAÇÃO - Campus "Luiz de Queiroz"/USP
}

\author{
Parré, José Luiz \\ O agronegócio nas macrorregiōes brasileiras: 1985 a 1995 / José Luiz Parré. - \\ Piracicaba, 2000
}

$191 \mathrm{p}$.

Tese (doutorado) - Escola Superior de Agricultura Luiz de Queiroz, 2000.

Bibliografia.

1. Aspectos económicos 2. Desenvolvimento agricola 3. Economia agricola 4. Estabilização econômica 5 . Industria agricola 6. Pesquisa 7. Política comercial 8. Relação insumo-produto 1 . Título

CDD 338.13

"Permitida a cópia total ou parcial des $t$ documento, desde que citada a fonte - $\mathbf{O}$ autor" 
Este trabalho é dedicado à memória de Carlos Décio Parré, meu querido irmão, "obrigado pelo incentivo" 
Rosana, minha esposa, Renata, minha filha, Amo vocês.

Minha mãe, Leonor, Pela dedicação em minha formação. 


\section{AGRADECIMENTOS}

Ao meu orientador, Prof. Joaquim José Martins Guilhoto, pela dedicação e incentivo em todos os momentos desta pesquisa.

Ao Prof. Geraldo S.A. de Camargo Barros, que iniciou a orientação desta pesquisa e continuou acompanhando o seu desenvolvimento com valiosas sugestões.

Ao Prof. Joaquim Bento S. Ferreira Filho, pelo apoio e sugestões apresentadas.

Ao corpo docente do Departamento de Economia, Administração e Sociologia da ESALQ/USP, pelos conhecimentos transmitidos durante o curso, principalmente ao Prof. Paulo F.C. de Araújo.

Aos colegas do Departamento de Economia da Universidade Estadual de Maringá, pelo apoio recebido, principalmente aos Profs. Ricardo Lopes, Antônio C. Campos, Marina Cunha e Alexandre Alves.

À CAPES, que prestou auxílio financeiro à pesquisa.

Aos funcionários do DEAS/ESAL/USP, em especial à Luciane, Maielli, Helena, Cristiane, Elenice e Valdeci, pelo apoio e amizade.

Aos colegas Francisco Crócomo, Suely Silveira, Rossana Lott, e Antônio C. Moretto que, gentilmente, auxiliaram na obtenção de dados para esta pesquisa.

Aos colegas do curso, pelos inesquecíveis momentos que passamos juntos, em especial aos amigos Patrízia, Roberto, Montoya, Ricardo Martins, Warly e Armando.

$\mathrm{E}$, finalmente, a todas as pessoas e instituições que, direta ou indiretamente, colaboraram para a realização deste trabalho. 


\section{SUMÁRIO}

Página

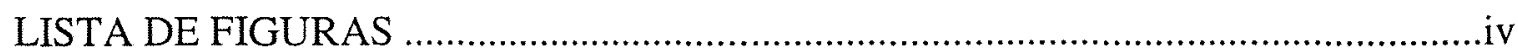

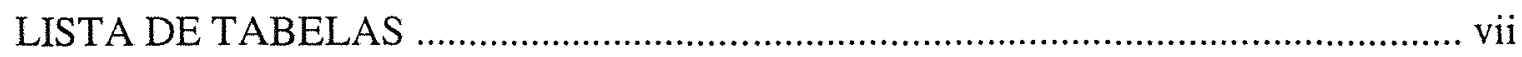

LISTA DE QUADROS ...................................................................................

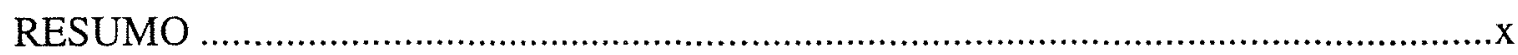

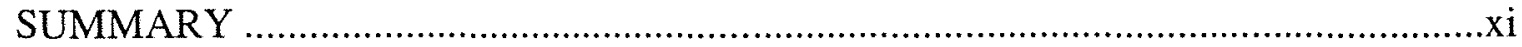

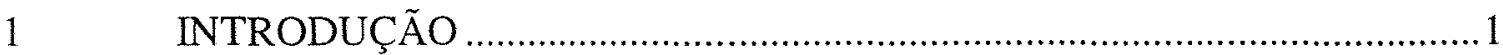

1.1 Identificação do problema e importância do estudo .....................................3

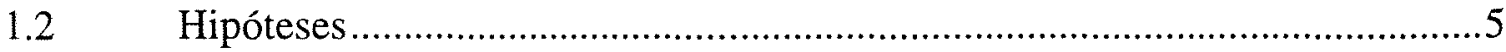

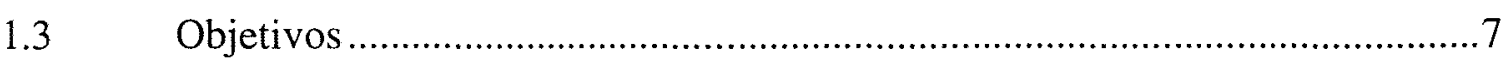

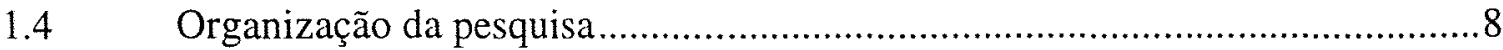

2 O DESENVOLVIMENTO DAS REGIÕES BRASILEIRAS:

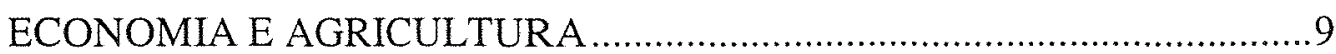

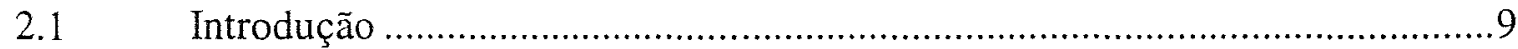

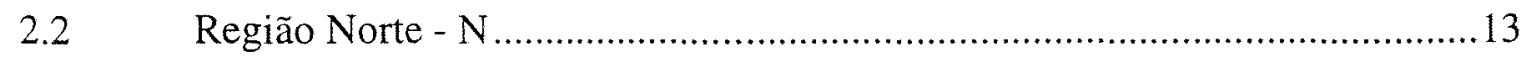

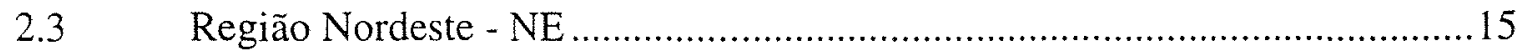

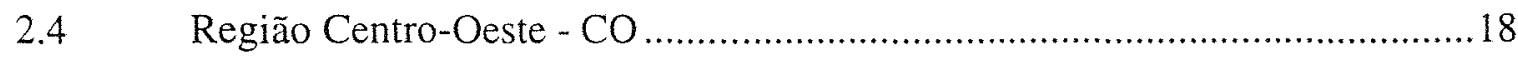

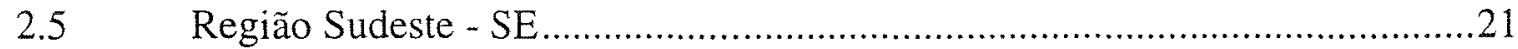

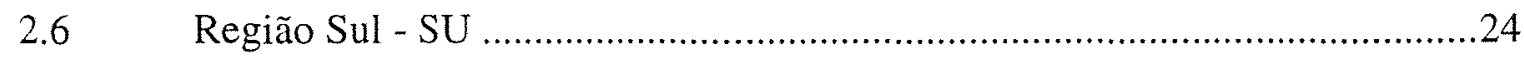

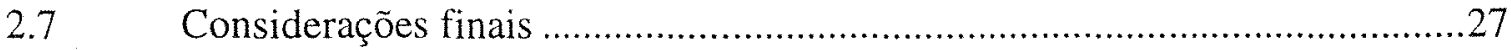

3 CARACTERIZAÇÃO DO AGRONEGÓCIO NO BRASIL ........................31

3.1 Breve histórico da indústria alimentar no Brasil.....................................31

3.2 O enfoque do agronegócio ...............................................................40

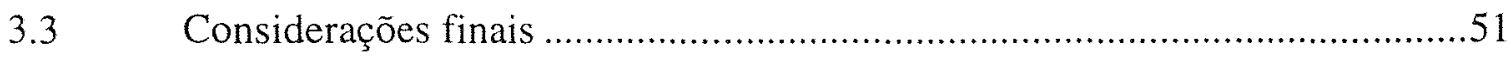




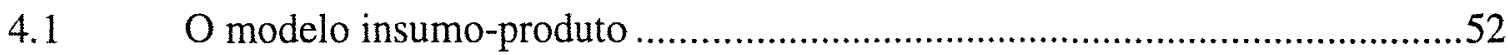

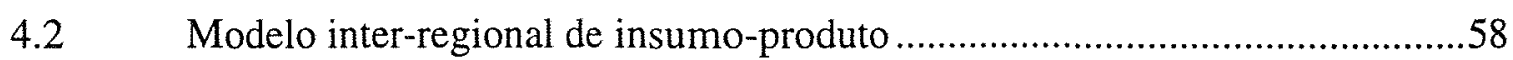

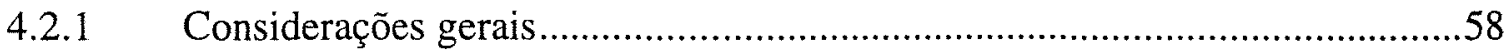

4.2.2 Enfoque inter-regional de insumo-produto .................................................. 61

4.2.3 Obtenção de coeficientes regionais ...............................................................65

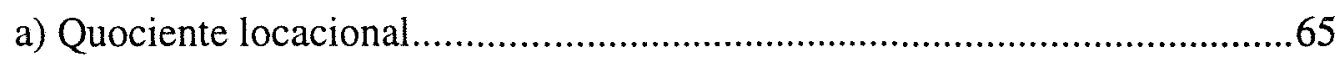

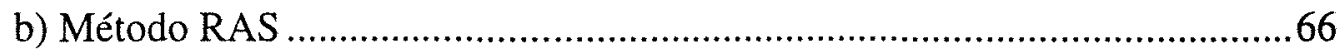

4.3 Obtenção dos dados e apresentação das matrizes ...........................................70

4.4 Dimensionamento do agronegócio para as regiões brasileiras ........................73

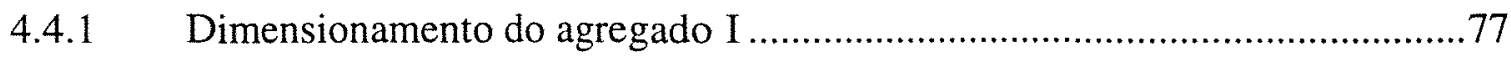

4.4.2 Dimensionamento do agregado II .............................................................

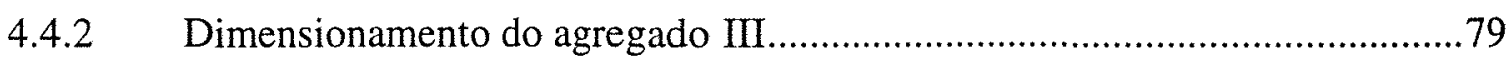

5 REGIONALIZAÇÃO DO AGRONEGÓCIO BRASILEIRO …......................85

5.1 A participação das regiões no agronegócio para o ano de 1985 ........................85

5.2 A participação das regiões no agronegócio para o ano de 1990 ........................90

5.3 A participação das regiões no agronegócio para o ano de 1995 .......................95

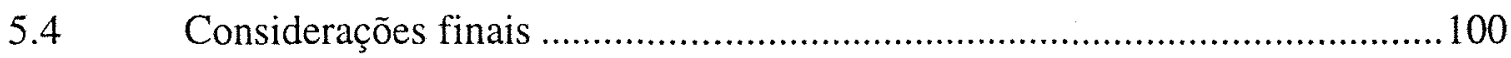

6 A COMPOSIÇÃO DO AGRONEGÓCIO DAS REGIÕES

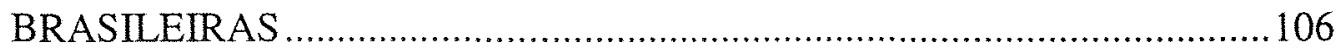

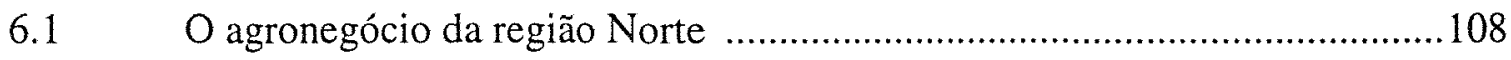

6.2 O agronegócio da região Nordeste ............................................................111

6.3 O agronegócio da região Centro-Oeste .......................................................113

$6.4 \quad$ O agronegócio da região Sudeste ..............................................................116

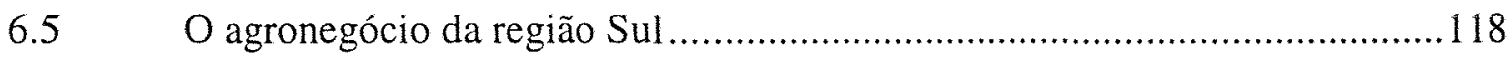

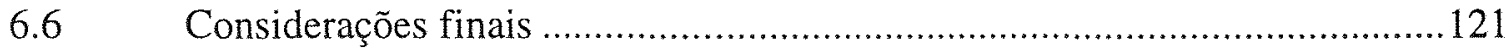


AS TRANSAÇÕES INTERREGIONAIS DO AGRONEGÓCIO

BRASILEIRO 126

7.1 Exportações e importações do agronegócio brasileiro 126

7.2 As transações interregionais da região Norte. 131

7.3 As transações interregionais da região Nordeste 134

7.4 As transações interregionais da região Centro-Oeste 137

7.5 As transações interregionais da região Sudeste 140

7.6 As transações interregionais da região Sul 143

7.7 Considerações finais 146

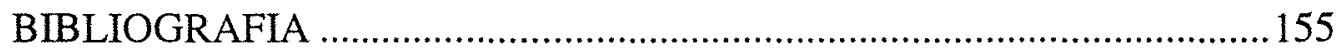

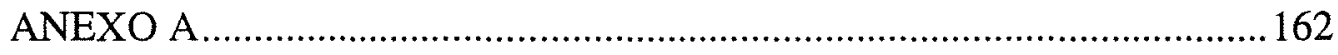

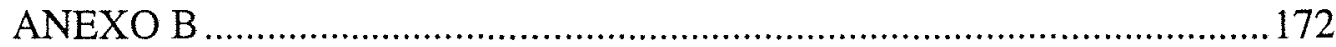

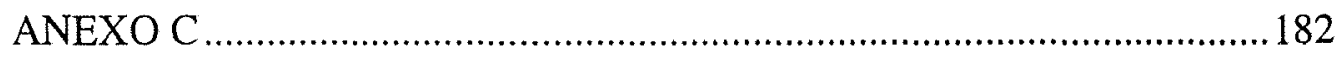




\section{LISTA DE FIGURAS}

Página

2.1: Participação da região Norte no PIB total e setorial do Brasil, 1985/96, em \%......15

2.2: Distribuição do PIB da região Norte por setores econômicos, 1985/95, em \% .......15

2.3: Participação da região Nordeste no PIB total e setorial do Brasil, 1985/96, em $\%$

2.4: Distribuição do PIB da região Nordeste por setores econômicos, 1985/95, em $\%$

2.5: Participação da região Centro-Oeste no PIB total e setorial do Brasil, 1985/96, em $\%$

2.6: Distribuição do PIB da região Centro-Oeste por setores econômicos, 1985/95, em $\%$

2.7: Participação da região Sudeste no PIB total e setorial do Brasil, 1985/96, em \% ...23

2.8: Distribuição do PIB da região Sudeste por setores econômicos, 1985/95, em \% ....24

2.9: Participação da região Sul no PIB total e setorial do Brasil, 1985/96, em \% .........26

2.10: Distribuição do PIB da região Sul por setores econômicos, 1985/95, em \% .........26

2.11: Participação das regiões no PIB agrícola brasileiro, 1985 a 1996, em \%

2.12: Participação dos setores no PIB do Brasil e das regiões para os anos de 1985, 1990 e 1995. Em \%

5.1: Participação das regiões no valor total do agronegócio do Brasil, em \%. 100

5.2: Participação das regiões no valor do agregado I (montante) do agronegócio brasileiro, em \%

5.3: Participação das regiões no valor do agregado II (produção agropecuária) do agronegócio brasileiro, em \%

5.4: Participação das regiões no valor da produção agroindustrial do Brasil, $\mathrm{em} \%$

5.5: Participação do agronegócio na composição do PIB das regiões e do Brasil, em \%

6.1: Participação do agronegócio na composição do PIB do Brasil, em \% 106 
6.2: Constituição do agronegócio do Brasil, segundo os seus agregados, em \% 107

6.3: Participação do agronegócio na composição do PIB da região Norte , em \% 109

6.4: Constituição do agronegócio da região Norte, segundo os seus agregados, em $\%$

6.5: Participação da região Norte no valor total do agronegócio do Brasil, e de seus agregados, em $\%$.

6.6: Participação do agronegócio na composição do PIB da região Nordeste , em \%

6.7: Constituição do agronegócio da região Nordeste, segundo os seus agregados, em $\%$

6.8: Participação da região Nordeste no valor total do agronegócio do Brasil, e de seus agregados, em \%

6.9: Participação do agronegócio na composição do PIB da região Centro-Oeste , em $\%$

6.10: Constituição do agronegócio da região Centro-Oeste, segundo os seus agregados, em \%.

6.11: Parcela da região Centro-Oeste no valor total do agronegócio do Brasil, e de seus agregados, em $\%$

6.12: Participação do agronegócio na composição do PIB da região Sudeste, em $\%$

6.13: Constituição do agronegócio da região Sudeste, segundo os seus agregados, em $\%$

6.14: Parcela da região Sudeste no valor total do agronegócio do Brasil, e de seus agregados, em $\%$

6.15: Participação do agronegócio na composição do PIB da região Sul , em \%

6.16: Constituição do agronegócio da região Sul, segundo os seus agregados, em \%

6.17: Parcela da região Sule no valor total do agronegócio do Brasil, e de seus agregados, em $\%$ 
6.18: Participação do agregado I (montante) no valor total do agronegócio do Brasil e das regiões, em \%

6.19: Participação do agregado II (produção agropecuária) no valor total do agronegócio do Brasil e das regiões, em \%.

6.20: Participação do agregado III (jusante) no valor total do agronegócio do Brasil e das regiões, em \%

6.21: Participação da produção agroindustrial no valor total do agronegócio do Brasil e das regiões, em \%

7.1: Participação das regiões no valor total exportado pela economia brasileira, 1985, 1990 e 1995, em percentagem.

7.2: Participação das regiões no valor total exportado pelo agronegócio brasileiro, 1985, 1990 e 1995, em percentagem

7.3: Parcela do valor total da produção do agronegócio que é exportado (para as demais regiões e para o exterior), 1985, 1990 e 1995, em \% 


\section{LISTA DE TABELAS}

Página

1.1: Alguns indicadores das desigualdades regionais do Brasil.....................................6

2.1: Distribuição do PIB por setores econômicos, 1985-1995 (em \%) .............................11

2.2: Brasil: participação das macrorregiões no PIB total e setorial, 1985-1995 $(\mathrm{em} \%)$

3.1: Indústria de transformação - Taxas de crescimento anual segundo períodos

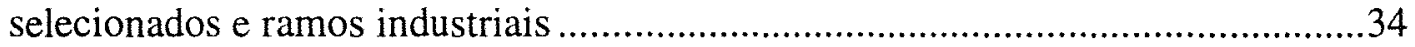

3.2: Índices do crescimento da produção industrial-Brasil, 1980/95 ……........................36

3.3: Mudanças na estrutura industrial-Brasil, 1949-92, (\%)...............................................38

3.4: Consumo de alimentos no Brasil, 1993=100. 1994/1997 …....................................39

3.5: Evolução do faturamento de segmentos selecionados da indústria brasileira de alimentos, em bilhões de dólares e percentagens, 1985 e 1995 39

3.6: PIB a custo de fatores do complexo agroindustrial. Brasil - 1980/1994.

(em porcentagem -\%)

3.7: Participação relativa e em dólares* do agronegócio no Produto

Interno Brasileiro. Período 1959 a 1995.

4.1: Matriz de insumo produto inter-regional, Brasil 1985, em bilhões de cruzeiros de 1985

4.2: Matriz de insumo-produto inter-regional para o Brasil, 1985. Em bilhões de

Cr\$ de 1985

4.3: Matriz de insumo-produto inter-regional para o Brasil, 1990. Em milhões de

Cr\$ de 1990 .

4.4: Matriz de insumo-produto inter-regional para o Brasil, 1995. Em mil R\$

5.1: A constituição do agronegócio das regiões brasileiras para o ano de 1985.

Total em Cr\$ Bilhões .86

5.2: A participação das regiões na composição do agronegócio do Brasil.

1985. Total em Cr\$ Bilhões 
5.3: A constituição do agronegócio das regiões brasileiras para o ano de 1990.

Total em Cr\$ Milhões

5.4: A participação das regiões na composição do agronegócio do Brasil.

1990. Total em Cr\$ Milhões

5.5: A constituição do agronegócio das regiões brasileiras para o ano de 1995.

Total em R $\$$ Mil

5.6: A participação das regiões na composição do agronegócio do Brasil.

1995. Total em R\$Mil

7.1: Exportações e importações segundo as regiões do Brasil. Em milhões

de dólares correntes, 1970 a 1995

7.2: Distribuição espacial das exportações por casses de produtos. Em \% ……............128

7.3: Participação das regiões nas exportações e importações para o exterior .................130

7.4: As transações comerciais do agronegócio da região Norte ....................................133

7.5: As transações comerciais do agronegócio da região Nordeste.................................136

7.6: As transações comerciais do agronegócio da região Centro-Oeste.........................139

7.7: As transações comerciais do agronegócio da região Sudeste...................................142

7.8: As transações comerciais do agronegócio da região Sul ........................................145

7.9: Brasil - Exportação - Principais produtos - 1995 ................................................... 147

A.1: Versão completa da matriz de insumo-produto inter-regional para o Brasil,

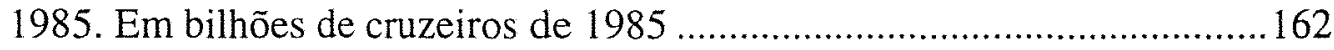

B.1: Versão completa da matriz de insumo-produto inter-regional para o Brasil,

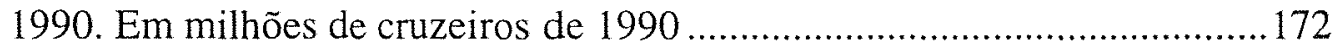

C.1: Versão completa da matriz de insumo-produto inter-regional para o Brasil,

1995. Em mil reais 


\section{LISTA DE QUADROS}

Página

4.1: Matriz de insumo-produto do tipo Leontief para três setores.....................................54

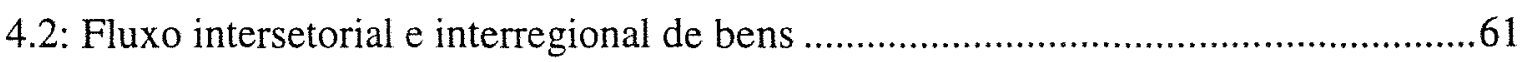

4.3: Matriz de insumo-produto simplificada para dimensionar o agronegócio da região Sudeste $(\mathrm{O})$ do Brasil .74 


\title{
O AGRONEGÓCIO NAS MACRORREGIÕES BRASILEIRAS: 1985 A 1995
}

\author{
Autor: José Luiz Parré \\ Orientador: Prof. Dr. Joaquim José Martins Guilhoto
}

\section{RESUMO:}

A meta principal desta tese é analisar o nível de desenvolvimento do agronegócio ou complexo agroindustrial das macrorregiões brasileiras para os anos de 1985, $1990 \mathrm{e}$ 1995, utilizando matrizes de insumo-produto inter-regionais. São apresentados resultados sobre a participação das macrorregiões na constituição do agronegócio brasileiro e a composição deste dentro das regiões, e sobre as principais características dos fluxos interregionais do agronegócio do Brasil. As principais conclusões da pesquisa são: a) houve desconcentração espacial no agronegócio total e em seus segmentos (agregados I ou montante, II ou produção agropecuária e III ou jusante) entre 1985 e 1995; essa desconcentração fica caracterizada pela diminuição da parcela da região Sudeste, que detinha $46 \%$ do valor do agronegócio do país em 1985, passando a concentrar $41,2 \%$ em 1995 ; b) houve diminuição generalizada da relação agronegócio/PIB, tanto no Brasil quanto em suas macrorregiões, entre 1985 e 1995, sendo que essa relação foi, para o Brasil, 38,6\% em 1985 contra 30,4\% em 1995; c) identifica-se uma grande heterogeneidade estrutural no agronegócio brasileiro, variando de região para região, principalmente quando se comparam os segmentos de processamento, armazenamento e distribuição final de produtos agropecuários (jusante do agronegócio); d) as exportações do agronegócio são menos concentradas quando comparadas com o padrão de distribuição espacial das exportações totais da economia brasileira; e e) dentro das regiões, as exportações do agronegócio são mais importantes para as periféricas. 


\title{
THE AGRIBUSINESS IN THE BRAZILIAN MACRO REGIONS: 1985 to 1995
}

\author{
Author: José Luiz Parré \\ Adviser: Prof. Dr. Joaquim José Martins Guilhoto
}

\section{SUMMARY:}

The main goal of this thesis is to analyze the level of development in the Agribusiness of the 5 Brazilian macro regions for the years of 1985, 1990 and 1995; using inter-regional input-output analysis. The results obtained show: a) how the macro regions contribute to the Brazilian Agribusiness; b) how the Agribusiness is structured inside the regions; and c) how the trade flows of the Agribusiness take place among the regions. The main findings of this work are: a) there was a decrease in the concentration in the Agribusiness and their components (aggregate I, II and III) between 1985 and 1995; with decrease in the share of the region Sudeste of $46 \%$ in 1985 to $41,2 \%$ in 1995; b) there was a decrease in the share of the Agribusiness in the Brazilian GNP as well as in the regions GRP, between 1985 and 1995, this share for the Brazil was 38,6\% in 1985 and $30,4 \%$ in $1995 ; \mathrm{c}$ ) the structure of the Agribusiness is particular to every region with different levels of development, mainly when the segments of processing, storage and distribution are considered; d) the exports of the Agribusiness are less concentrated when compared with the Brazilian spatial distribution of its exports; and e) the exports of the Agribusiness are much more important for the less developed regions. 


\section{INTRODUÇÃo}

Existe um consenso na literatura sobre o desenvolvimento regional brasileiro [por exemplo: IPEA (1997)] quanto ao comportamento da distribuição da atividade econômica no território nacional, sendo que, desde 1950 até os dias atuais, houve três diferentes momentos (com base nas estimativas do produto interno nas regiões brasileiras). O primeiro seria de concentração, englobando o período de $1950^{1}$ a 1975 ; o segundo, em que houve desconcentração da atividade econômica no país, aproximadamente, é caracterizado pelo período de 1975 a 1985; o terceiro seria o de estabilização da posição relativa das diferentes regiões brasileiras.

Entretanto, a desigualdade entre as regiões a respeito de crescimento e distribuição de renda tem sido uma característica da economia brasileira desde os tempos coloniais, e cada um dos ciclos de exportação de produtos primários do passado beneficiou uma ou outra região específica. Segundo Baer (1995), "a substituição histórica de regiões economicamente favorecidas chegou ao fim no século $X X$, com a região Sudeste do país, que era a área dinâmica de exportação no início do processo de industrialização, tornado-se a região líder da economia brasileira".

Guimarães Neto ${ }^{2}$, citado por Galvão \& Vasconcelos (1999), também analisa o desenvolvimento brasileiro sob uma perspectiva espacial, identificando três fases nesse processo:

\footnotetext{
${ }^{1}$ Certamente, o período de concentração existiu antes de 1950, mas pode ser caracterizado pelo período assinalado, pois é o mesmo em que se iniciou a industrialização da agricultura brasileira.

2 GUIMARĀES NETO, L. Dinâmica regional no Brasil. Brasília, DIPRU/IPEA, versão preliminar, fevereiro de 1997.
} 
a) fase do isolamento relativo ou do arquipélago regional representado pelos antigos complexos exportadores, que perdurou até o princípio deste século;

b) fase da articulação comercial, concomitante com a primeira etapa da industrialização brasileira, que perdurou até os anos 60; e

c) fase da integração produtiva, que alcançou os anos 80 .

Segundo esse autor, "A concentração quase secular esteve associada e foi determinada, em grande parte, pelos processos que ocorreram, na fase de isolamento relativo, e que deram lugar ao dinamismo diferenciado das regiões e complexos exportadores regionais, e à fase mais recente de formação do mercado interno, quando as demais economias regionais - não o Sudeste ajustam os seus espaços econômicos à concorrência da produção industrial sudestina, que avança sobre os mercados regionais, anteriormente isolados. Já o processo de desconcentração, a que se assiste a partir da segunda metade dos anos 70, tem uma relação muito clara, como se verá, com a integração produtiva. O esgotamento desse processo ocorre a partir da segunda metade dos anos 80 e tem, seguramente, estreita relação com o agravamento da crise econômica do país e com a crise fiscal e financeira do Estado brasileiro"(Guimarães Neto ${ }^{3}$, citado por Galvão \& Vasconcelos, 1999).

O período recente, iniciado na segunda metade da década de 80 , pode ser considerado uma quarta fase do desenvolvimento econômico espacial brasileiro, e é um período de "nem concentração, nem desconcentração" espacial, pela falta de uma definição mais clara de tendências (Galvão \& Vasconcelos, 1999).

No final da década de 60 , tomou vulto no país uma nova estratégia de modernização, cujos reflexos no setor agrícola traduziram-se na consolidação do modelo

\footnotetext{
${ }^{3}$ Op. cit.
} 
de complexos agroindustriais ou agronegócio, na reformulação da política agrícola e na criação de incentivos à verticalização da produção.

Esse processo refletiu-se de forma diferenciada nas regiões brasileiras, devido às desigualdades que existem entre estas. Neste sentido, a preocupação básica desta pesquisa é relacionar as diferenças preexistentes entre as regiões brasileiras e as que surgiram na consolidação e estruturação do agronegócio nestas regiões. Além disso, pretende-se analisar se a importância relativa das regiões na constituição do valor total dos bens e serviços produzidos no país se mantém quando o foco da análise se volta apenas para os complexos agroindustriais ou agronegócio das regiões brasileiras.

\subsection{Identificação do problema e importância do estudo}

Ao analisar o "novo padrão agrícola brasileiro", Hoffmann et al. (1985) observam que "Todas essas transformações ... apresentam uma característica comum..., que é a de terem se processado de forma desigual em dois sentidos: regionalmente, beneficiaram os estados do Centro-Sul, particularmente o estado de São Paulo; dentro de cada estado, atingiram preferencialmente os médios e grandes estabelecimentos agropecuários. É preciso enfatizar, porém, que, já em 1960, essas características regionais e entre estabelecimentos eram acentuadas, devido à própria evolução histórica de cada região...".

Associando estes aspectos da modernização da agricultura brasileira às características do surgimento e da expansão do complexo agroindustrial ou agronegócio brasileiro, ou seja, o aperfeiçoamento das relações agricultura-indústria, que não se deu de modo uniforme e simultâneo em todo o país, chega-se ao seguinte questionamento, que, de certa maneira, resume a essência desta pesquisa: de que forma o nível de desenvolvimento das regiões brasileiras determina a constituição e a influência do agronegócio nas regiões e entre estas, e como o agronegócio afeta o desenvolvimento 
regional e, particularmente, o desenvolvimento da agricultura regional. Neste sentido, são testados os parâmetros sugeridos por Malassis (1969), que relacionam o grau de desenvolvimento das regiões e a estrutura do agronegócio. Esses parâmetros são apresentados no item 4.4 desta tese.

Para exemplificar o problema em questão, observa-se o caso das regiões Sudeste e Norte. A região Sudeste é a que apresenta os melhores indicadores econômicos e sociais, funcionando como pólo de desenvolvimento para o país, como demonstrado por Crócomo (1998). Nessa região, encontravam-se, em 1996, 35,7\% da produção agropecuária, 62,3\% da industrial e 59,2\% da produção de serviços do Brasil (Tabela 1.1), sendo que, com essas participações, o sudeste configurou-se como líder destes três setores da economia nacional. Quando se analisa a importância destes para essa região, verifica-se que, apesar de sua agricultura ser "a mais moderna" (Hoffmann et al., 1985) e de ter o maior valor de produção entre todas as regiões do Brasil, nela, esse setor participou com apenas 7\% do Produto Interno Bruto (PIB) da região em 1995 (Tabela 2.1); e, no período 1985/95, a região apresentou diminuição da importância do setor agrícola. Por outro lado, a região Norte participou com $8,4 \%$ do total da produção agropecuária do Brasil (Tabela 1.1), enquanto a parcela desse setor no Produto Interno Bruto da região, em 1995, foi de $21 \%$ (Tabela 2.1).

Tendo esse panorama regional como pano de fundo, surgem as seguintes questões sobre o agronegócio das regiões do Brasil:

- Qual a importância do agronegócio para as regiões do país (sua dimensão econômica e seu impacto sobre os outros setores da região)?;

- Qual a importância do agronegócio da região em relação ao valor total do agronegócio brasileiro?;

- Qual o pólo do agronegócio (montante ou jusante) que possui maior influência sobre o setor de produção rural?; 
- Qual a importância da região como importadora e exportadora de insumos para o setor agrícola das demais regiões do país?;

- Qual a importância da região como importadora e exportadora de produtos agrícolas processados para os consumidores das demais regiões do país?;

- Qual a importância das exportações dentro do agronegócio regional (relação valor exportado/valor produzido pelo agronegócio da região)?;

- Quais as alterações no comportamento do agronegócio regional que aconteceram no período de 1985 a 1995 e, destas, quais podem ter sido causadas por políticas governamentais de desenvolvimento das regiões?.

Esta tese pressupõe que a tentativa de esclarecimento de questões desse tipo, para o agronegócio de todas as regiões do país, configura-se em uma proposta de grande importância para o desenvolvimento do agronegócio nas regiões brasileiras e, por consequiência, para o desenvolvimento econômico do Brasil.

Com a metodologia sugerida, pensa-se ser possível alcançar resultados que permitam responder a esses questionamentos e a outros que por ventura surjam no decorrer da execução desta pesquisa.

\subsection{Hipóteses}

O desenvolvimento desta pesquisa inicia-se a partir das seguintes hipóteses básicas:

- A dinâmica do setor agropecuário é cada vez mais influenciada pelo desempenho dos setores econômicos a ele relacionados. Deve-se privilegiar, portanto, a análise do complexo agroindustrial ou agronegócio como forma de compreender as transformações que acontecem na agricultura de uma região. 
- Ao longo do período de análise (1985 a 1995), houve uma desconcentração espacial do valor da produção do agronegócio brasileiro, acompanhando a desconcentração ocorrida na economia como um todo.

Tabela 1.1: Alguns indicadores das desigualdades regionais do Brasil

\begin{tabular}{lccccccc}
\hline \multicolumn{1}{c}{ Discriminação } & Ano & Norte & Nordeste & Sudeste & Sul & CO & Brasil \\
\hline \multicolumn{1}{c}{ PIB } & & & & & & & \\
- Total (\%) & 1996 & 5,22 & 13,54 & 58,12 & 15,83 & 7,29 & 100,00 \\
-Per capita (Brasil = 100) & 1994 & 68,06 & 48,38 & 132,87 & 117,85 & 108,01 & 100,00 \\
- Setorial & & & & & & & \\
Agropecuária (\%) & 1996 & 8,41 & 17,00 & 35,72 & 27,39 & 11,48 & 100,00 \\
Industrial (\%) & 1996 & 5,03 & 13,75 & 62,32 & 15,18 & 3,72 & 100,00 \\
Serviços (\%) & 1996 & 4,59 & 12,68 & 59,20 & 14,58 & 8,95 & 100,00 \\
\hline Indicadores demográficos & & & & & & & \\
População & & & & & & & \\
Total (\%) & 1997 & 7,27 & 28,40 & 42,64 & 14,95 & 6,75 & 100,00 \\
Urbana (\%) & 1991 & 5,34 & 23,22 & 49,76 & 14,78 & 6,90 & 100,00 \\
Rural (\%) & 1991 & 11,46 & 46,66 & 20,97 & 15,98 & 4,92 & 100,00 \\
\hline Indicadores de ocupação & 1995 & & & & & & \\
População ocupada (mil) & & 2.740 & 19.970 & 29.990 & 11.993 & 4.790 & 69.629 \\
\% sobre total do país & & 3,94 & 28,68 & 43,07 & 17,14 & 6,89 & 100,00 \\
\hline Índice desenv. humano & 1991 & & & & & & \\
Valor absoluto & & 0,706 & 0,548 & 0,838 & 0,844 & 0,826 & 0,797 \\
Relação (Brasil = 100) & & 88,58 & 68,76 & 105,14 & 105,90 & 103,64 & 100,00 \\
\hline
\end{tabular}

Fonte: IPEA (1997); Considera \& Medina (1998). (organizada pelo autor) 


\subsection{Objetivos}

Como objetivo geral, esta tese pretende analisar o nível de desenvolvimento do agronegócio ou complexo agroindustrial das macrorregiões da economia brasileira para os anos de 1985, 1990 e 1995; utilizando matrizes insumo-produto inter-regionais.

Para atingir esta meta, é necessário cumprir as seguintes etapas, que podem ser consideradas objetivos específicos da presente pesquisa:

a) devido ao fato de a matriz inter-regional disponível das macrorregiões brasileiras (desenvolvida por Crócomo e Guilhoto, 1998) apresentar como base o ano de 1985, é necessário, através da metodologia insumo-produto, obter a mesma matriz para 1990 e 1995 ;

b) desenvolver uma metodologia que permita analisar o agronegócio de cada região isoladamente e suas inter-relações com a economia e com o agronegócio das demais regiões do país;

c) calcular a dimensão do agronegócio nas regiões brasileiras, bem como a participação de cada região na composição do complexo agroindustrial brasileiro em 1985, 1990 e 1995, a fim de determinar a importância deste complexo dentro de cada uma (por exemplo: quais regiões são mais dependentes e quais as diferenças estruturais) e o nível de inserção de cada região no complexo agroindustrial brasileiro;

d) verificar a evolução do complexo agroindustrial das regiões do Brasil, por meio de uma análise comparativa dos resultados dos três períodos em estudo, o que permite determinar a resposta do setor e das regiões às políticas governamentais de desenvolvimento;

e) estudar o impacto do comércio inter-regional e internacional em que o agronegócio das regiões está inserido, ou seja, calcular o valor das 
exportações e importações referentes à atividade em cada região do país, e verificar suas relações com o Exterior e as demais regiões do Brasil.

\subsection{Organização da pesquisa}

Neste sentido, o trabalho divide-se em 8 capítulos. Inicia-se com este capítulo introdutório, que apresenta os objetivos da tese. Os capítulos 2 e 3 apresentam a revisão de literatura: no capítulo 2, analisa-se o desenvolvimento da economia e da agricultura nas regiões brasileiras; o 3 trata do desenvolvimento do agronegócio no país, identificando algumas linhas de estudos. No capítulo 4 , é apresentada a metodologia da pesquisa, dividida em quatro seções: a primeira mostra o modelo insumo-produto; a segunda apresenta o modelo inter-regional; a terceira apresenta a metodologia de atualização de matrizes (método RAS) e os dados utilizados na pesquisa; e a quarta seção trata do dimensionamento do agronegócio para as regiões brasileiras. Os capítulos 5, 6 e 7 apresentam os resultados obtidos para 1985, 1990 e 1995. O capítulo 5 apresenta uma análise comparativa entre o agronegócio das regiões do Brasil; o 6 aprofunda a análise, tratando cada região de modo isolado; e, no capítulo 7 , são discutidas as exportações e importações realizadas pelo agronegócio regional. Por fim, no capítulo 8, são apresentadas as conclusões da tese. 


\section{O DESENVOLVIMENTO DAS REGIÕES BRASILEIRAS: ECONOMIA E AGRICULTURA}

Este capítulo tem como meta principal discutir como surgiram algumas das desigualdades das regiões brasileiras, principalmente aquelas relacionadas com o setor agrícola e agroindustrial. O direcionamento da revisão busca informações que serão úteis na interpretação dos resultados que serão obtidos neste estudo.

\subsection{Introdução}

A ocupação e o povoamento do Brasil se deram por meio de surto de atividades exportadoras que, sucedendo-se ao longo do tempo, foram fixando populações em diferentes pontos do território nacional. E, conforme o sucesso ou insucesso da exploração econômica - em particular, a capacidade ou incapacidade de levar à diversificação e à industrialização - estabeleceram-se diferenciações nítidas entre esses focos isolados de civilização, bem retratadas nos indicadores econômicos e sociais, consagrando a herança regional do desenvolvimento do país.

Nesse sentido, o ciclo da cana-de-açúcar nos séculos XVI e XVII favoreceu o Nordeste; o de exploração de ouro (séculos XVII e XVIII) levou o dinamismo da economia para a área de Minas Gerais e do Sudeste do país; a expansão da exportação de café do século XIX favoreceu primeiro o interior do Rio de Janeiro e, posteriormente, o estado de São Paulo. No século XX, entretanto, segundo Baer (1995), a substituição histórica de regiões economicamente favorecidas chegou ao fim. O Sudeste do país, que 
era a área dinâmica de exportação no início do processo de industrialização, tornou-se também a região líder da economia brasileira e o principal beneficiário do crescimento econômico do país.

Pode-se concluir, então, que a história econômica das regiões brasileiras se confunde com a história da industrialização do País e da constituição e consolidação do mercado interno brasileiro. Nesses processos, foi tomando forma uma divisão interregional de trabalho e, em consequiência, foram se definindo estruturas produtivas e papéis diferenciados para cada região no interior da economia nacional, com repercussões sobre o desenvolvimento econômico e as condições de vida nas distintas regiões (BRASIL, 1993).

Baseado em critérios de homogeneidade e funcionalidade, ou seja, nos aspectos geo-econômicos, o IBGE admite a seguinte divisão regional do Brasil:

\section{Região Norte}

Sete Estados: Amazonas, Pará, Acre, Amapá, Roraima, Rondônia e Tocantins.

\section{Região Nordeste}

Nove Estados: Maranhão, Piauí, Ceará, Rio Grande do Norte, Paraíba, Pernambuco, Alagoas, Sergipe e Bahia.

\section{Região Centro-Oeste}

Três Estados: Mato Grosso, Mato Grosso do Sul e Goiás.

Distrito Federal: Brasília

\section{Região Sudeste}

Quatro Estados: Espírito Santo, Minas Gerais, Rio de Janeiro e São Paulo.

\section{Região Sul}

Três Estados: Paraná, Santa Catarina e Rio Grande do Sul. 


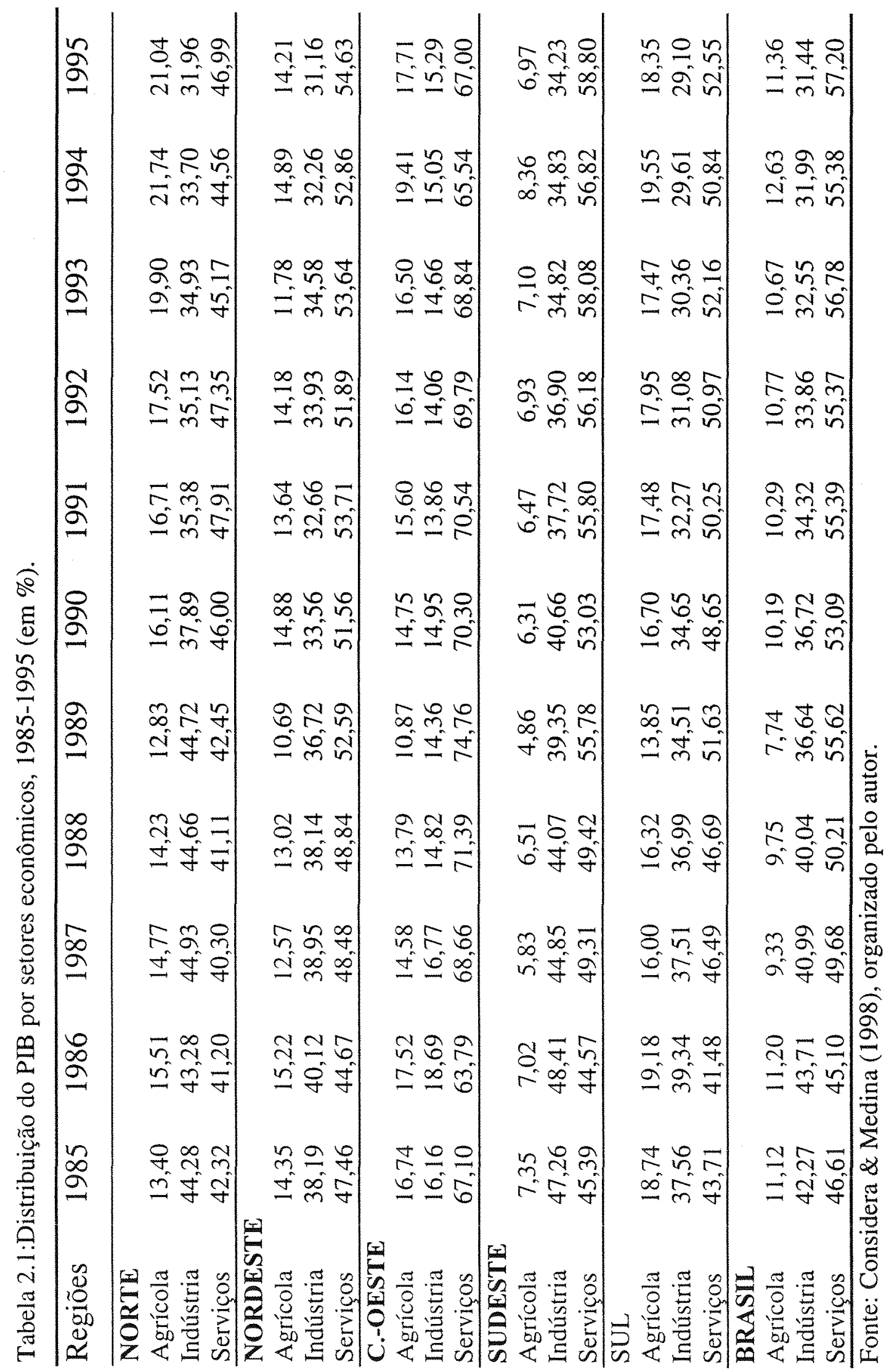




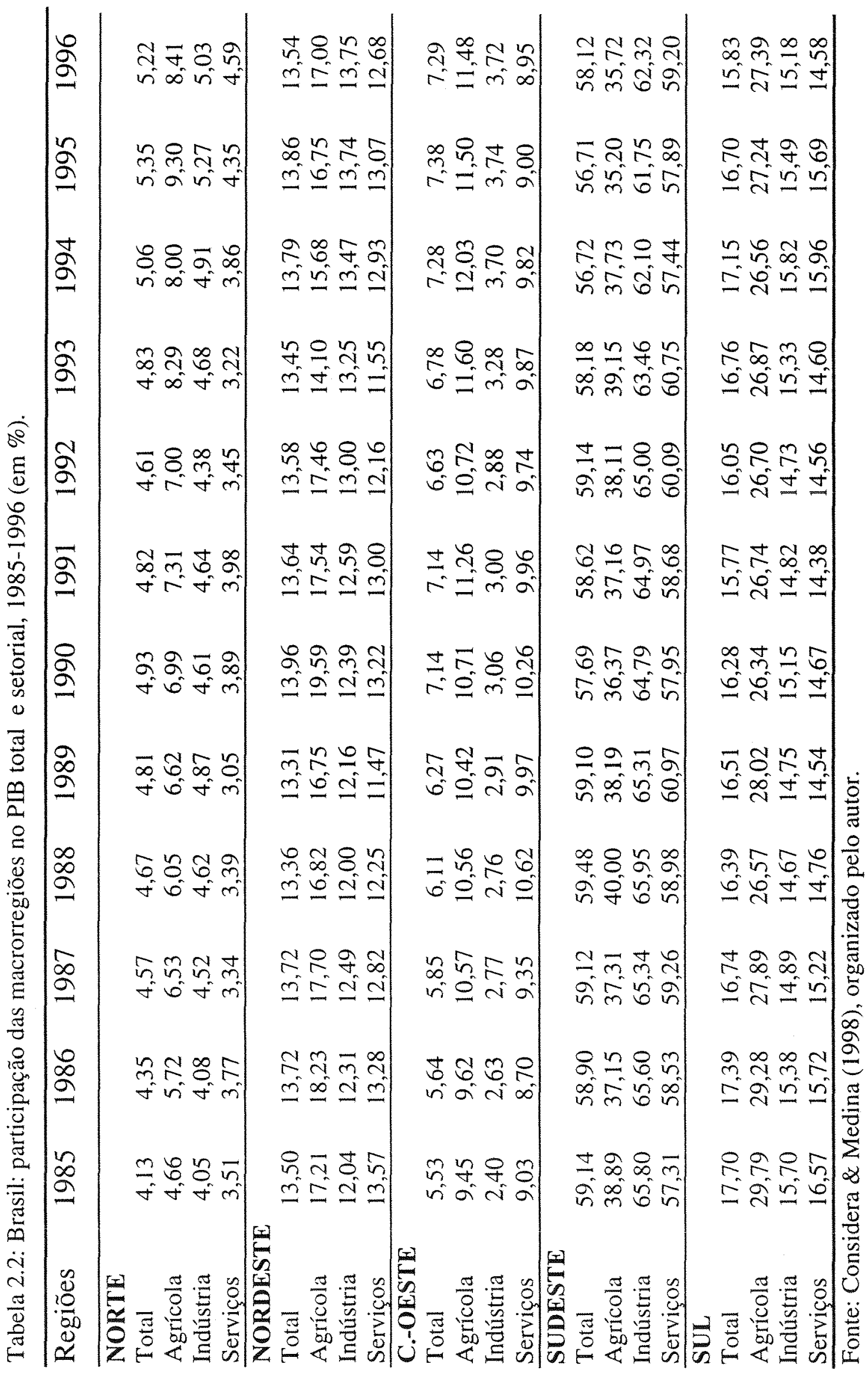




\subsection{Região Norte - N}

A Amazônia permanece até o início da Segunda metade do século XIX como uma economia de extrativismo, com quase nenhuma integração ao mercado nacional. A exportação de borracha propiciou uma grande expansão da região, no período de 1870 a 1912, porém este surto expansionista não conseguiu desenvolver na região uma economia dinâmica do ponto de vista capitalista. A região permaneceria estagnada até o início da década de 1940, quando então se vincularia ao mercado nacional através da produção de borracha, fibras (malva e juta) e pimenta-do-reino.(Cano, 1981 e Hoffmann et al, 1985)

Durante as décadas de 70 e 80 , a região Norte registrou crescimento do PIB mais intenso do que o país como um todo, na primeira metade dos anos 80 a taxa de crescimento regional foi cerca de cinco vezes superior ao do país. Ainda assim, o PIB da região Norte é muito inferior ao potencial da região, atingindo uma participação máxima de 5,3\% na composição do PIB nacional, obtido no ano de 1995 (tabela 2.2).

Em 1950, a agropecuária foi responsável por quase 1/3 do produto regional, diminuindo em importância relativa até 1985 e recuperando-se em 1995, produzindo, respectivamente, $13,4 \%$ e $21,0 \%$ do produto regional. O setor industrial apresentou comportamento inverso, participou com apenas $11,3 \%$ da produção, em 1950, chegando a 1985 com 44,3\% do produto regional, para perder importância em 1995 participando com apenas 32,0\%. Os serviços apresentam grande participação em 1985 e 1995, com $42,3 \%$ e 47,0\%, respectivamente, (tabela 2.1 e BRASIL,1993). A queda do setor industrial reflete uma crise na produção industrial na Zona Franca de Manaus.

A mudança na posição relativa entre os setores da indústria e dos serviços pode ser visualizado na figura 2.2, esta figura também demonstra o aumento na participação do setor agrícola no período 1985/1995. Um dos motivos do crescimento do setor de serviços, como observa Cano (1998), foi a elevada taxa de urbanização da região, que 
passou de 42,0\% em 1970, para 58,0\% em 1991; estimulando a criação e a diversificação de atividades ligadas ao setor de serviços.

A importância da região Norte para a composição do PIB setorial do Brasil pode ser analisada pela tabela 2.2 e pela figura 2.1. Pode-se perceber que a região Norte é a que menos participa do PIB nacional, tanto em nível agregado (PIB total) quanto desagregado (com exceção do setor industrial, que supera a participação da região Centro-Oeste); porém, entre os setores o que melhor se coloca é a agropecuária com uma participação de $8,4 \%$ em 1996, e o pior é o setor de serviços com participação de $4,6 \%$ no mesmo período.

A evolução do setor agropecuário caracteriza-se pelo crescimento de $407 \%$ na área dedicada à lavoura permanente, enquanto que a lavoura temporária registra aumento de $178 \%$ entre 1970 e 1985 . O padrão tecnológico da agricultura do norte também avançou, ocorrendo a tecnificação da atividade a taxas superiores às observadas para o país como um todo, ainda que as diferenças absolutas em relação ao Sudeste, Sul e Centro-Oeste sejam muito grandes. No reajuste resultante dessas transformações, as atividades do extrativismo vegetal e das culturas alimentares perderam espaço, enquanto o cultivo de produtos agrícolas para exportação cresceu (BRASIL, 1993).

Na Amazônia (principalmente em Rondônia e no Pará), a expansão do setor agropecuário se deve ao aumento dos efetivos de bovinos e aves, ao arroz, ao feijão, à mandioca e ao milho, lavouras típicas da pequena produção de "fronteira" (Cano, 1998).

O setor agropecuário da região Norte beneficiou-se de várias políticas empreendidas pelo Governo Federal no sentido de estimular o crescimento e desenvolvimento da região. Entre 674 projetos agropecuários e agroindustriais aprovados pela SUDAM (Superintendência do Desenvolvimento da Amazônia) até 1985, 94 foram tidos como implantados. Mas apenas três desses 94 projetos tinham alguma rentabilidade no período, sendo que um único aspecto da política de incentivos fiscais funcionou como o previsto: a concessão de recursos oficiais (BRASIL, 1993). 


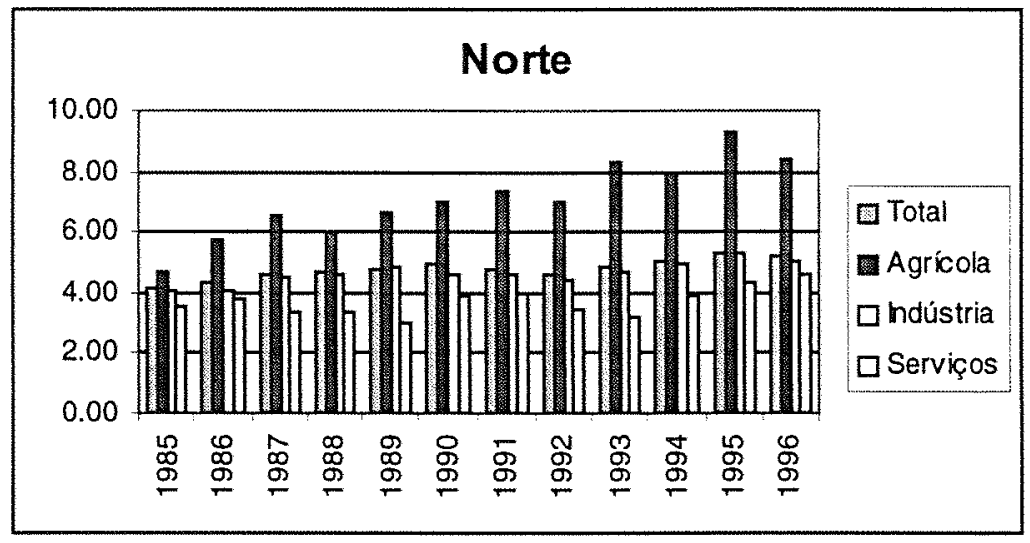

Fonte: Considera e Medina (1998), organizado pelo autor.

Figura 2.1: Participação da região Norte no PIB total e setorial do Brasil, 1985/96, em \%.

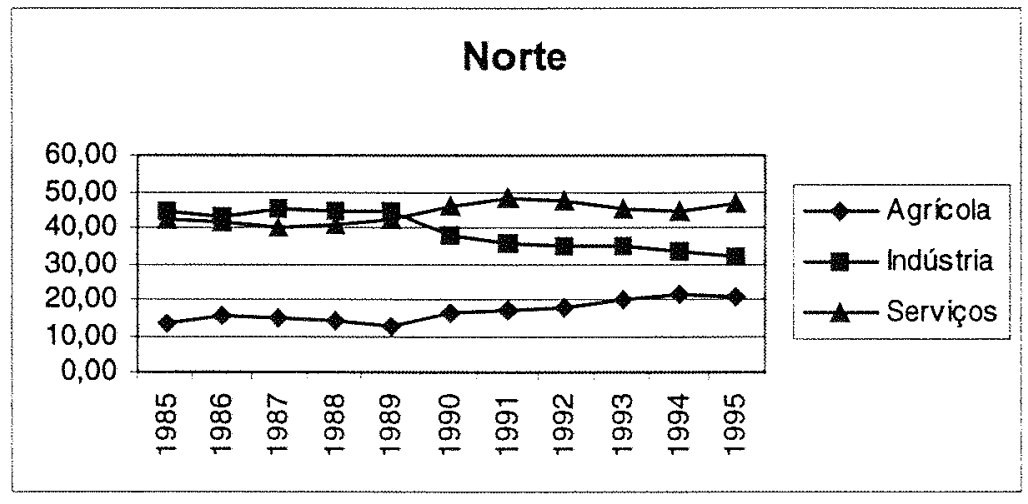

Fonte: Considera e Medina (1998), organizado pelo autor.

Figura 2.2: Distribuição do PIB da região Norte por setores econômicos, 1985/95, em \%.

\subsection{Região Nordeste - NE}

O Nordeste experimenta, já no século XIX, a decadência do açúcar e do algodão, que se tornam produtos marginais no mercado internacional, enquanto a pecuária, associada com a agricultura de subsistência, permitiria a manutenção e reprodução do "grande reservatório de mão-de-obra nacional". Depois de 1929, soma-se o fato de São Paulo também incrementar a produção de açúcar (passando a ser em 1955 o maior 
produtor individual) e algodão para o mercado interno, ficando cada vez mais difícil o desenvolvimento industrial do Nordeste (Hoffmann et al, 1985).

No período de 1970-75 a participação do Nordeste no PIB brasileiro caiu, significando que a região não se beneficiou significativamente da fase do "milagre". A partir de 1975 o crescimento ocorre e a região como um todo se beneficia dos maciços investimentos que são realizados, contudo, o crescimento é muito variado e diferenciado.

A região NE tem se integrado com as regiões mais dinâmicas do país, principalmente através dos pólos químico e petroquímico. Entretanto, apesar do impacto positivo nas taxas de crescimento da economia nordestina, o processo de integração interregional não tem apresentado fortes encadeamentos intrarregionais que se manifestem sob a forma de estímulos a todos os setores e atividades econômicas do Nordeste (BRASL, 1993).

Nas décadas de 70 e 80 ocorreram algumas transformações pontuais e localizadas na agricultura nordestina. Estas transformações decorreram do incremento de algumas culturas não tradicionais do Nordeste, que, pelo valor de mercado relativamente alto, passaram a ter participação maior no valor da produção agrícola do NE. O aumento da produção de frutas (mamão, manga, melancia e uva) deveu-se à expansão da agricultura irrigada na área do submédio São Francisco; o aumento da produção de cacau e abacaxi respondeu à expansão do cultivo em manchas climáticas favoráveis do sertão e do agreste. Também ocorreu aumento da participação relativa do tomate, do café, da soja e da borracha. Esses produtos que, conjuntamente, representavam, em 1970, 3,1\% do valor da produção agrícola do NE, elevaram sua participação para 13,5\%, em 1989 (BRASI, 1993).

Ao analisar, pela tabela 2.1 e figura 2.4 , a composição do PIB regional do Nordeste verifica-se que a agricultura manteve uma participação média de 14,0\% no período 1985/1995, atingindo o valor máximo de 14,9\% em 1990. O setor industrial apresentou um decréscimo em sua participação no período analisado, caindo de $38,2 \%$ 
em 1985 para $31,2 \%$ em 1995. E o setor de serviços apresentou um aumento de $47,5 \%$ em 1985 para $54,6 \%$ em 1995, mantendo-se como o setor mais importante da região.

A participação da região Nordeste na composição do PIB setorial do Brasil pode ser analisada pela tabela 2.2 e pela figura 2.3. Percebe-se que a região Nordeste contribui em média com aproximadamente $13,5 \%$ do PIB nacional total, porém, entre os setores o que melhor se coloca é a agropecuária com uma participação média de 17,0\% no período 1985/1995, enquanto os setores industrial e de serviços participam, em média, com $12,7 \%$.

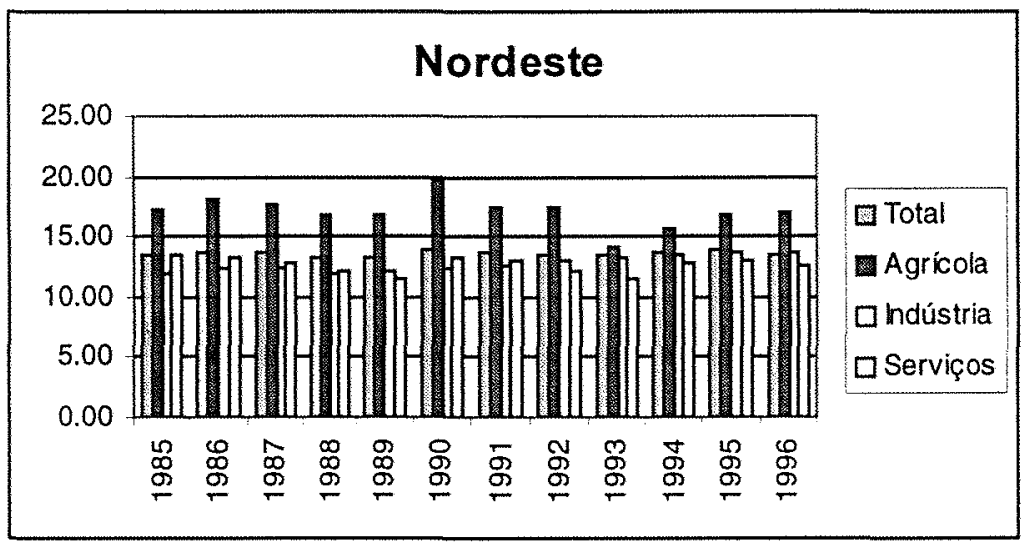

Fonte: Considera e Medina (1998), organizado pelo autor.

Figura 2.3: Participação da região Nordeste no PIB total e setorial do Brasil, 1985/96, em \%.

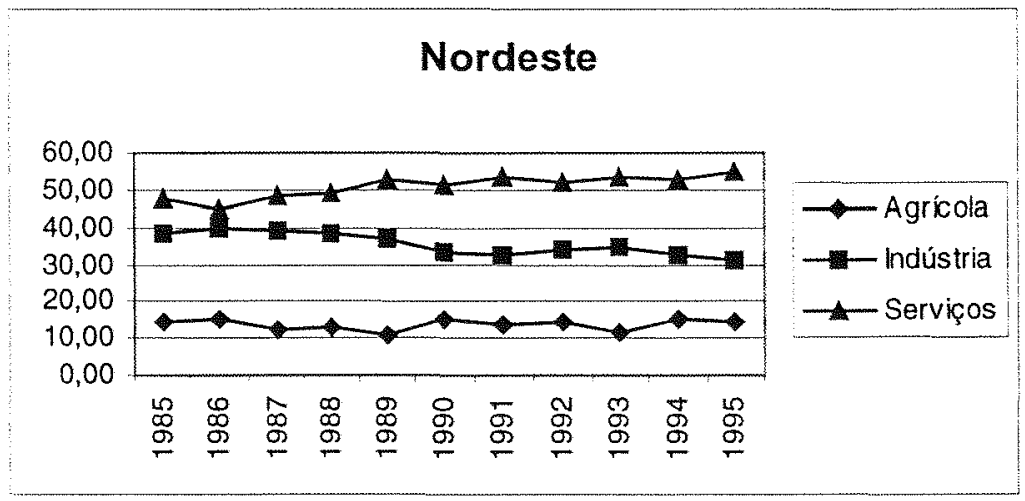

Fonte: Considera e Medina (1998), organizado pelo autor.

Figura 2.4: Distribuição do PIB da região Nordeste por setores econômicos, 1985/95, em \%. 


\subsection{Região Centro-Oeste - CO}

Junto com a região Norte, a região Centro-Oeste era até pouco tempo considerada um dos grandes "vazios" nacionais. Do ponto de vista da produção agrícola, a região Centro-Oeste estava nos anos 40 e 50 deste século apenas no início da abertura de sua fronteira, apresentando nessas décadas taxas de crescimento bastante elevadas para os principais produtos agropecuários. O processo de ocupação da fronteira (e especialmente o incremento demográfico) na região se intensifica na década de 60 , em função principalmente da construção de Brasília e da construção da rede viária a ela relacionada (Hoffmann et al, 1985).

A modernização da agricultura da região ocorreu durante o processo de integração do mercado nacional sob o comando da economia paulista, as áreas vazias e próximas a São Paulo foram as mais predispostas a receber impactos positivos dessa integração, funcionando como uma espécie de "frente avançada do capitalismo paulista", preponderantemente através de seu setor agrícola (Cano, 1981).

A existência de áreas que possibilitavam a expansão da fronteira agrícola, associada a incentivos oficiais às atividades exportadoras, levou à dinamização das culturas processáveis industrialmente e passíveis de serem colocadas no mercado internacional em condições competitivas. Estes movimentos levaram a maior concentração fundiária na região, na década de 70 e, principalmente, a consolidação da agroindústria como atividade dinâmica e integradora da região. Esta ampliação das atividades agroindustriais também levou à incorporação de progresso técnico na agricultura da região, para atender às exigências de produtividade e homogeneidade do produto destinado ao processamento industrial e à exportação (BRASIL, 1993).

A análise da evolução da agroindústria no período de 1970 a 1990 aponta para um crescimento acelerado e ganhos de produtividade de um grupo de produtos considerados "modernos", como o milho, importante insumo para a avicultura e a suinocultura, o arroz e a soja, que receberam intensivo apoio governamental, em 
detrimento do grupo de lavouras "tradicionais", como o feijão e a mandioca, que ficaram à margem dos incentivos. Para citar um exemplo, a produção de soja da região CentroOeste, que representava $0,5 \%$ da produção nacional em 1970, passou a representar $40,0 \%$ em 1995.

Sobre a pecuária deve-se salientar que essa atividade beneficiou-se de uma conjunção de ações levadas a efeito pelo Estado, como o acesso ao crédito rural, programas especiais como abertura de grandes eixos viários e incentivos fiscais, dando assim, condições para que a atividade criatória se elevasse satisfatoriamente (BRASIL, 1993).

A região Centro-Oeste cresceu, no período 1970-1985, a taxas mais aceleradas que o Brasil. Entretanto, o Brasil teve sua fase de maior crescimento nos primeiros 5 anos da década de 70, impulsionado pelo "milagre", enquanto que a dinâmica do $\mathrm{CO}$ toma impulso a partir da Segunda metade dos anos 70, chegando a atingir uma taxa de crescimento de $14,2 \%$ ao ano. Em termos setoriais, o maior dinamismo foi do segmento industrial, fortemente estimulado pelas atividades agropecuárias e minerais da região, quando cresceu em torno de $30 \%$ ao ano entre 1975 e 1980. Tal crescimento, contudo, não resultou em impactos importantes na economia da região, dado o pequeno peso desse setor na sua estrutura produtiva (BRASIL, 1993).

São as atividades agropecuárias que, por sua magnitude e dinamismo, vão proporcionar à região Centro-Oeste crescimento expressivo. De fato, observa-se que, em 1975, o PIB agropecuário do CO correspondia a 7,4\% do PIB primário brasileiro, alcançando em 1985 a marca de 9,5\% e em 1996, esta região participou com 11,5\% do valor da produção agropecuária nacional (BRASIL, 1993; tabela 2.2 e figura 2.5). Esse crescimento é reflexo, como já foi comentado, da expansão da fronteira agrícola da região. Essa expansão da produção agropecuária da região teve reflexos, também, na composição do PIB regional como pode ser visto pela tabela 2.1. O setor primário, que em 1985 participava com 16,7\% do PIB da região, aumentou sua participação para 
17,7\% em 1995. O setor industrial apresentou pequena diminuição em sua participação, caindo de 16,2\% em 1985 para 15,3\%em 1995.

Pela figura 2.6, percebe-se um comportamento peculiar da região Centro-Oeste com relação à grande diferença entre os setores de serviços e industrial na participação do PIB da região. Sem dúvida este comportamento diferenciado é causado pelo Distrito Federal, que apresenta significativo peso do setor terciário na geração da renda.

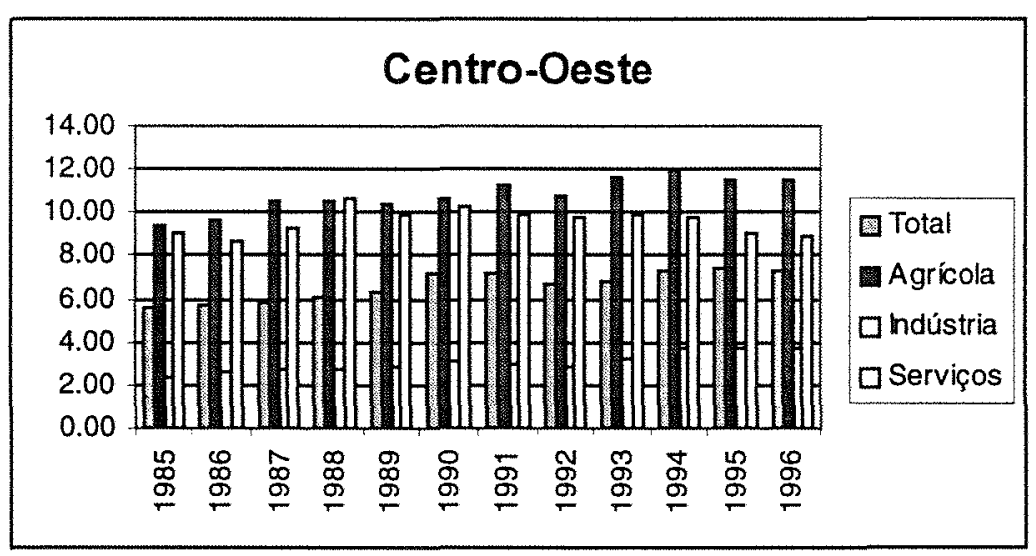

Fonte: Considera e Medina (1998), organizado pelo autor.

Figura 2.5: Participação da região Centro-Oeste no PIB total e setorial do Brasil, 1985/96, em $\%$.

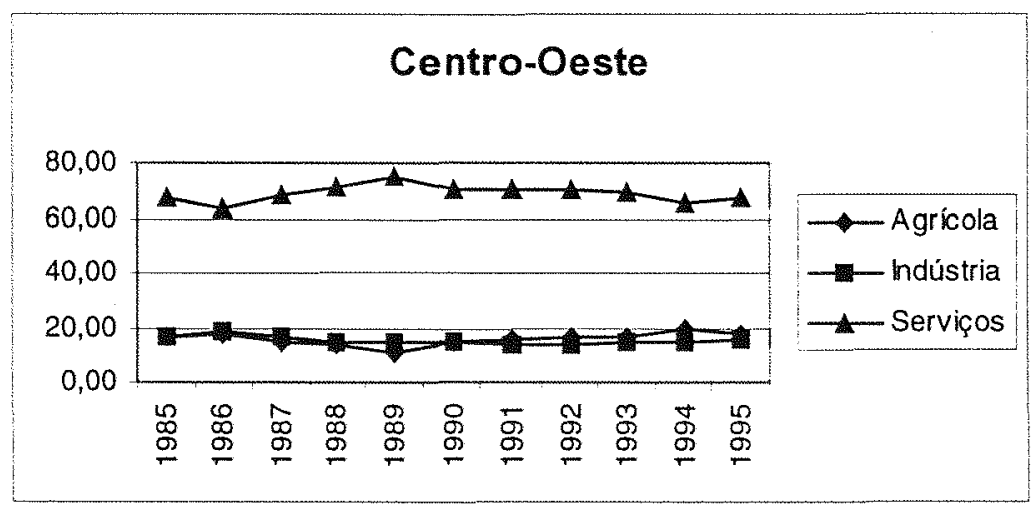

Fonte: Considera e Medina (1998), organizado pelo autor.

Figura 2.6: Distribuição do PIB da região Nordeste por setores econômicos, 1985/95, em \%. 


\subsection{Região Sudeste - SE}

A formação econômica recente da região Sudeste está estreitamente ligada à história da cultura do café e da industrialização no Brasil, apesar das diversidades entre os seus quatro estados componentes. Grande parte da região, abrangendo o Rio de Janeiro (exceto a baixada fluminense e a área de Campos, onde se desenvolve a atividade canavieira), o Espírito Santo, a Zona da Mata de Minas Gerais e o Vale do Paraíba, apresenta a característica comum de ter sido a primeira a ser ocupada pela cultura do café. Além dessas áreas, no entanto, a região Sudeste ainda possui outras áreas que dispõem de condições naturais favoráveis, especialmente no interior do estado de São Paulo. É na região Sudeste que se encontra a agricultura mais capitalizada do país, bem como se concentra a atividade industrial, notadamente no estado de São Paulo (Hoffmann et al, 1985).

O estado de São Paulo, devido à diversificação e ao dinamismo de sua agricultura pode ser tratado à parte. Além de contar com importante produção pecuária e de outros animais (avicultura cresce fortemente na década de 70), o estado de São Paulo concentra parcela significativa das culturas "modernas" como cana-de-açúcar, laranja, amendoim, soja e algodão. Nos outros estados a agricultura predomina nas seguintes áreas: zonas litorâneas e áreas do interior (encosta e planalto) onde se concentram o café, o arroz, a cana-de açúcar e o fumo. O café distribui-se basicamente no sul de Minas. Também no sul de Minas está concentrada a produção de arroz. A cana-de-açúcar concentra-se na região de Campos (RJ) (Hoffmann et al, 1985).

Ainda a respeito da agricultura, sobretudo nos anos 70, é importante ressaltar a expansão das atividades agroindustriais e a modernização ocorrida no setor, com redução significativa das culturas tradicionais e a expansão das exportáveis e processáveis industrialmente. A mecanização, expressa na relação pessoal ocupado/trator ou área de lavoura/trator, registrou aumento significativo de 1970 a 1980, com moderada evolução nos anos 80 (1980-85), em toda a região (BRASL, 1993). 
Após atingir baixas participações na produção agrícola nacional em 1980/1985 o estado de São Paulo reestrutura e diversifica seu setor agrícola, aumentando a produção de culturas exportáveis, pastagens, álcool e açúcar, laranja, carnes e frutas. Para essa reestruturação e expansão da produção foram usados, em termos adicionais líquidos, menos de um milhão de novos hectares (cerca de 5\% a mais do que utilizava-se em 1970). Os estados de Minas Gerais, Espírito Santo e Rio de Janeiro também realizaram substituição de áreas de cultivos e pastagens naturais (Cano, 1998).

Pela sua posição de concentrar grande parcela do PIB nacional (tabela 2.2), e o fato de possuir grande parte dos segmentos mais dinâmicos do país, a economia da região Sudeste apresentou um movimento, ao longo das décadas de 70 e 80 , bastante similar àquele observado para o Brasil como um todo; isto é, crescimento nos anos 70 de 9,7\% ao ano e quase estagnação entre 1980-85 com diminuição em sua participação relativa frente às demais regiões brasileiras em termos do nível de atividade econômica de $65,0 \%$ em 1970 para $59,0 \%$ em 1985.

A análise sumária dos determinantes do dinamismo do crescimento regional verificados nos anos 70, aponta, em primeiro lugar, para expansão do setor industrial. Parte da explicação deve ser procurada no segmento de bens intermediários, em particular na química, papel e papelão, minerais não metálicos e madeira. No segmento de bens de consumo duráveis e de capital, é importante destacar o papel da indústria de material de transporte, não só pelo seu crescimento relativo como pela geração de efeitos multiplicadores junto a um complexo conjunto de ramos industriais e de outros setores produtivos. Relativamente aos anos 80 , as informações revelam a estagnação de todas as Unidades da Federação do Sudeste. Em termos setoriais, a desaceleração alcançou de fato a economia urbana da região, com a indústria expandindo-se a apenas $1 \%$ e o conjunto das atividades terciárias não chegando a esta marca (BRASIL, 1993).

A evolução, caracterizada por grande dinamismo nos anos 70, e a estagnação nos anos 80 repercutiram na estrutura produtiva da região e de cada Estado em particular. Esse movimento ocorreu desigualmente, no interior da região, no que se refere tanto à 
indústria, na qual Rio e São Paulo perdem posição relativa, como à agricultura, uma vez que a redução relativa do setor no produto total não se deu de forma homogênea.

Nesta região encontram-se, para o ano de 1996, 35,7\% da produção agropecuária; $62,3 \%$ da produção industrial e $59,2 \%$ da produção de serviços no Brasil (tabela 2.2). Sendo que, com estas participações, o Sudeste lidera estes três setores da economia nacional. Quando analisa-se a importância destes setores para a região Sudeste (tabela 2.1) verifica-se que, apesar da agricultura na região Sudeste ser a mais moderna e com o maior valor de produção entre todas as regiões do Brasil, este setor participa com apenas 7,0\% do Produto Interno Bruto da região em 1995; e no período 1985/1995 a região apresentou uma diminuição da importância do setor agrícola.

O setor industrial teve sua importância diminuída na composição da produção regional caindo de $47,3 \%$, em 1985, para $34,2 \%$ no ano de 1995 . Este decréscimo da indústria foi compensado pelo setor de serviços, o qual aumentou sua participação na composição do PIB regional de $45,4 \%$ para $58,8 \%$, neste mesmo período considerado (tabela 2.1 e figura 2.8). Interessante notar que, além da indústria ter perdido participação regional na composição do PIB, pela figura 2.7 verifica-se que o setor industrial da região sudeste também diminuiu sua participação na produção industrial brasileira de 65,8\% em 1985 para 62,3\% no ano de 1996.

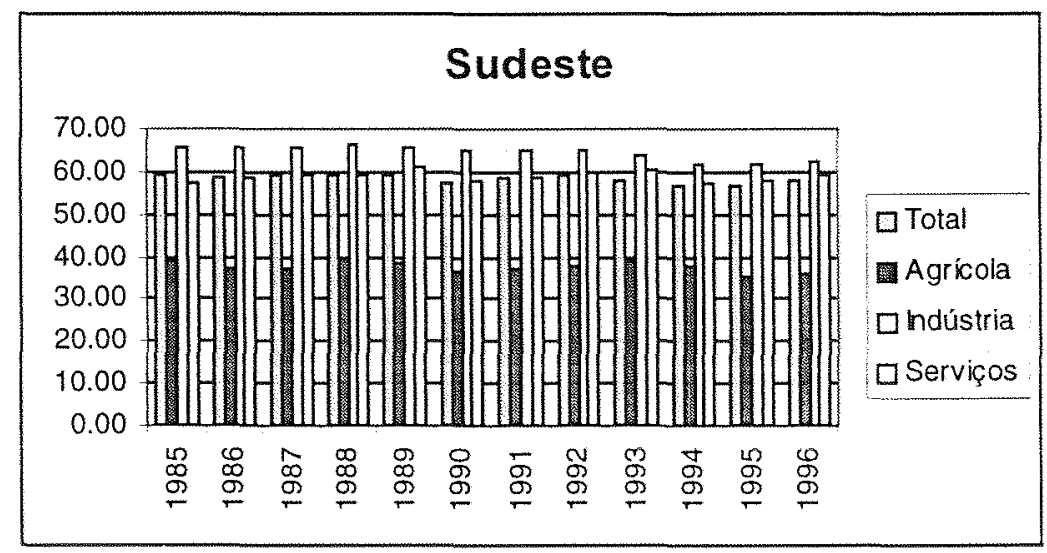

Fonte: Considera e Medina (1998), organizado pelo autor.

Figura 2.7: Participação da região Sudeste no PIB total e setorial do Brasil, 1985/96, em \%. 


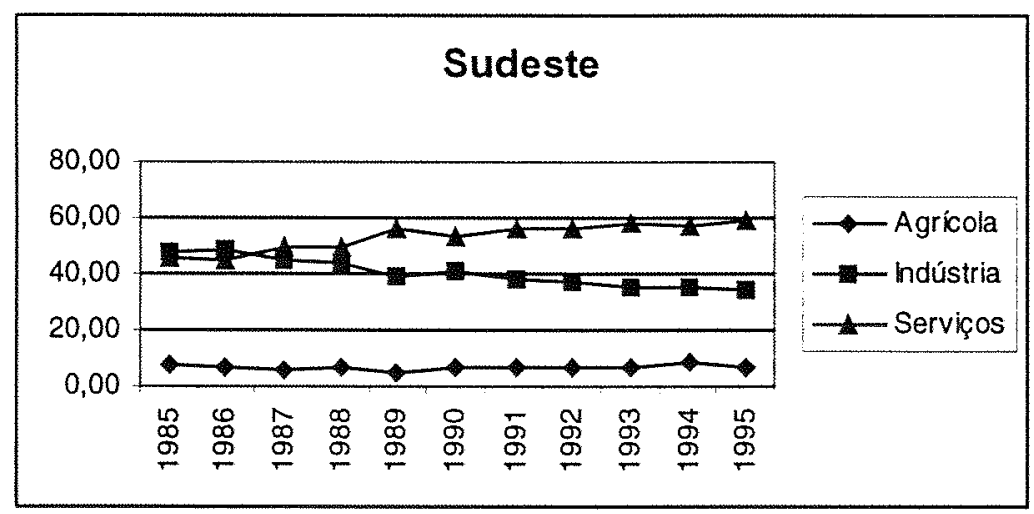

Fonte: Considera e Medina (1998), organizado pelo autor.

Figura 2.8: Distribuição do PIB da região Sudeste por setores econômicos, 1985/95, em \%.

\subsection{Região Sul - SU}

Os estados que compõem a região Sul apresentam particularidades bastante visíveis, em função principalmente de sua história econômica e sua formação social. O Paraná tem muitas de suas atuais características originadas da colonização influenciada pela economia cafeeira paulista, o que as torna muitos distintas, por exemplo, da baixa integração interna e do predomínio da pequena propriedade familiar que se observa em Santa Catarina. Já o Rio Grande do Sul, pela forma original de sua ocupação (basicamente para defesa da fronteira e para o fornecimento de animais à zona mineradora) e seu posterior desenvolvimento, tem hoje três tipos diferentes de agricultura: a pecuária extensiva tradicional, as áreas de lavoura empresarial (arroz, trigo, soja) e a agricultura colonial (policultura, fumo, uva) (Hoffmann et al, 1985).

Analisando de forma conjunta, a região caracterizava-se por possuir tanto uma agricultura como uma indústria tipificadas pela pequena e média propriedade, excetuando a pecuária no Rio Grande do Sul.

O processo de capitalização da agricultura sulina, assentado na produção de trigo, soja, arroz (irrigado) e pecuária extensiva, no período mais recente, provocou uma 
concentração fundiária na agricultura da região. Neste processo dois elementos foram importantes: de um lado, a expansão das agroindústrias ligadas ao complexo da soja (óleo, farelo, rações, etc.), no Paraná e Rio Grande do Sul, e as ligadas ao processamento de carnes suínas e de aves, em Santa Catarina; de outro lado, a reorientação do aparato político-institucional no sentido de dar suporte ao novo estilo de desenvolvimento agrícola. No caso específico da região sul, cabe destacar o papel das cooperativas, largamente difundidas nos três estados, no apoio à comercialização agrícola e na prestação de serviços (Hoffmann et al, 1985).

Pode-se esperar que o tipo de agroindústria que se desenvolveu na região Sul levou a uma diminuição na produção de alimentos básicos e também conduziu à mecanização da produção e à introdução de insumos modernos, proporcionando transferência dos estímulos dinâmicos da agricultura para segmentos da indústria. As mudanças implicam a introdução de novos produtos, novos tipos de organização da produção e novos processos tecnológicos.

Sem minimizar a intensidade das mudanças por que passou a agropecuária, o seu declínio relativo chama a atenção. Representando $25 \%$ do produto interno de 1970 , o setor apresentou uma queda expressiva, participando com 16,7\% do PIB em 1990. Em 1995 ocorreu uma recuperação chegando a participar com 18,3\%. O mesmo comportamento apresentou em relação ao PIB agrícola nacional, em 1985 a região Sul participava com $29,8 \%$ do valor da produção agrícola nacional, diminuindo essa participação para 26,3\% em 1990 e recuperando-se para chegar, em 1996, com 27,4\% do PIB agrícola do Brasil (tabelas 2.1 e 2.2 e figura 2.9).

A região Sul, apesar de perder peso relativo, continua dominando o setor de avicultura e de arroz irrigado com aproximadamente $70,0 \%$ da produção nacional; a região mantém suas participações na produção de feijão e milho e perde participação em bovinos, suínos, cebola, batata, tomate, soja, trigo e no algodão, segundo Cano (1998).

O setor industrial respondia, em 1970, por 20,0\% do PIB regional do Sul. Esta participação cresceu no início dos anos 80 chegando a representar 37,6\% em 1985, 
porém o setor também sentiu a crise do final da década de 80 e sua participação caiu para $34,6 \%$ do produto regional em 1990 e $29,1 \%$ em 1995 (figura 2.10). Sendo que o setor de serviços apresentou comportamento inverso no período, crescendo sua participação de $43,7 \%$ em 1985 para 52,5\% em 1995 (figura 2.10).

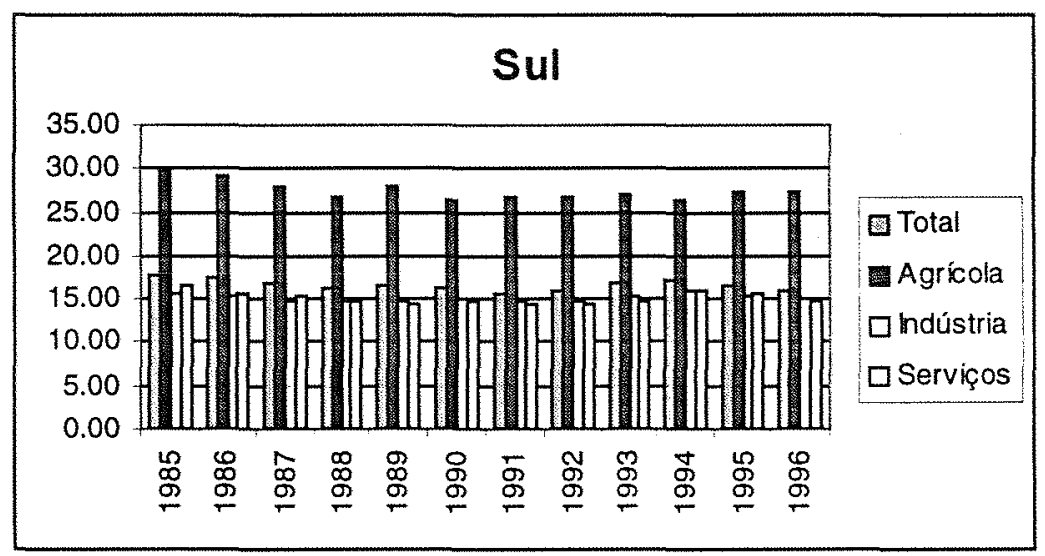

Fonte: Considera e Medina (1998), organizado pelo autor.

Figura 2.9: Participação da região Sul no PIB total e setorial do Brasil, 1985/96, em \%.

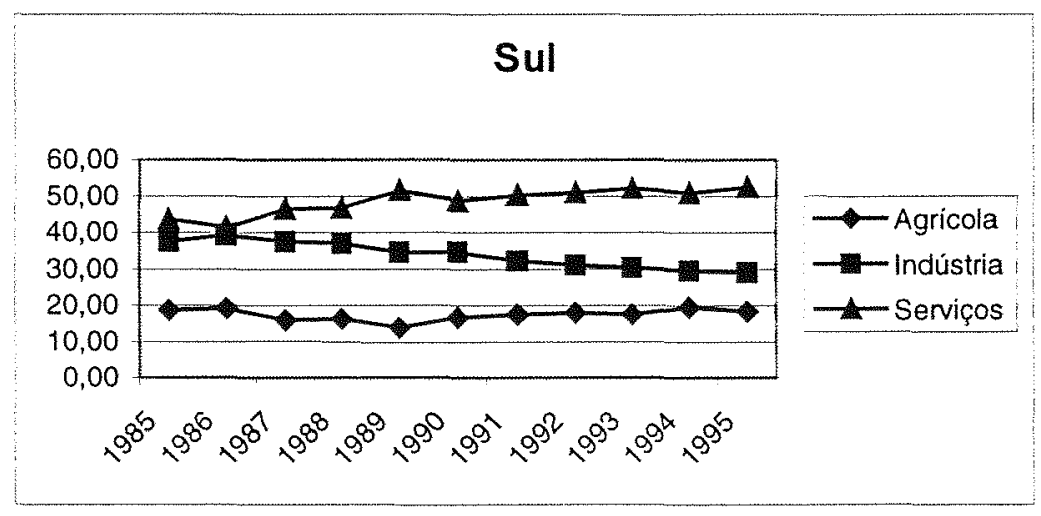

Fonte: Considera e Medina (1998), organizado pelo autor.

Figura 2.10: Distribuição do PIB da região Sul por setores econômicos, 1985/95, em \%. 


\subsection{Considerações finais}

Do exposto nas seções anteriores desse capítulo, pode-se observar uma certa alteração relativa na participação das regiões na composição do Produto Interno Bruto setorial do Brasil. Com relação à participação das regiões na composição do PIB da agricultura brasileira, a figura 2.11 demonstra que as posições foram mantidas no período de 1985 a 1996, com liderança da região Sudeste, seguida pelas regiões Sul, Nordeste, Centro-Oeste e Norte. Entretanto as diferenças entre as regiões diminuíram durante o período analisado, ou seja, os dados indicam uma pequena tendência à desconcentração na produção agrícola brasileira, no período de 1985 a 1996.

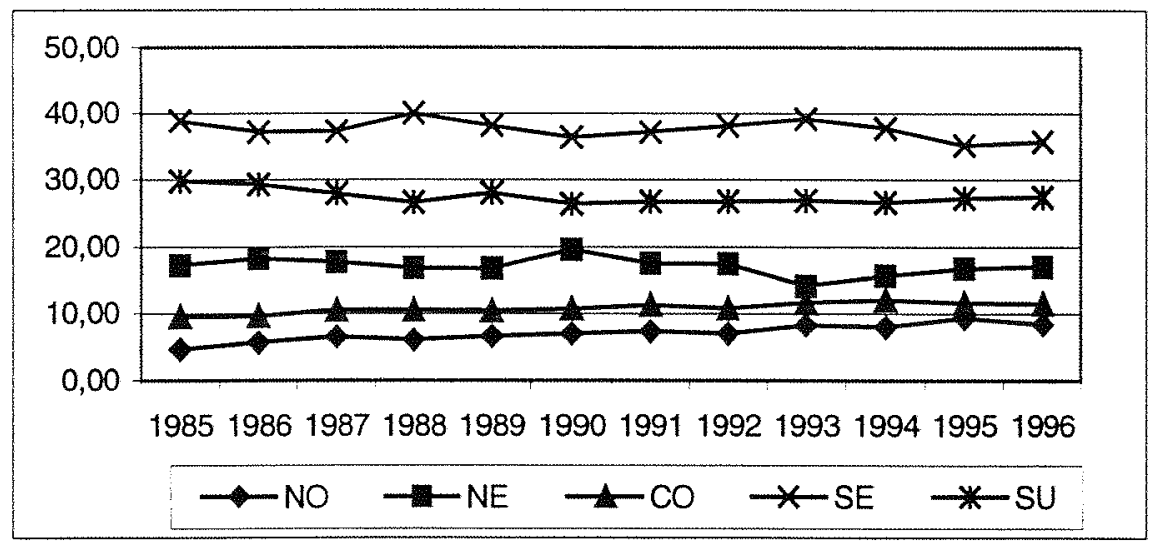

Fonte: Considera e Medina (1998), organizado pelo autor.

Figura 2.11: Participação das regiões no PIB agrícola brasileiro, 1985 a 1996, em \%.

Esta pequena tendência à desconcentração também é observada com relação ao PIB total das regiões (tabela 2.2), onde a Região Norte aumenta sua participação no PIB do Brasil de 4,1\% em 1985 para 5,2\% em 1996; o mesmo ocorrendo com a região Centro-Oeste (5,5\% em 1985 e 7,3\% em 1996). A participação da região Nordeste se mantém em $13,5 \%$ no período e as regiões Sudeste e Sul perdem participação relativa 
sendo que o Sudeste cai de $59,1 \%$ em 1985 para $58,1 \%$ em 1996 e a região Sul diminui sua participação de 17,7\% em 1985 para 15,8\% em 1996.

Esses resultados diferem um pouco daqueles obtidos por Cano(1998); que, ao analisar o processo de concentração e desconcentração da economia brasileira chega à seguinte conclusão: "O período 1970/95 envolve dois movimentos: o da acentuada desconcentração produtiva que se dá entre 1970 e 1985 e o seguinte, em que há uma inflexão nesse processo e até mesmo uma aparente reconcentração".

O motivo para essas diferenças na participação das regiões no PIB do Brasil provavelmente é o fato de que o IPEA (Instituto de Pesquisa Econômica Aplicada) realizou alterações no cálculo do PIB das regiões para o período 1990/1996, o que foi chamado de Novo Sistema de Contas Nacionais, sendo que esses novos dados foram publicados no final de 1998 (Considera \& Medina, 1998). Isto permite concluir que o Prof. Cano utilizou dados do Antigo Sistema de Contas Nacionais (1985/1995) ao contrário da presente pesquisa que utilizou, para o período 1990/1996, as informações contidas no Novo Sistema de Contas Nacionais.

Entretanto, obviamente, como as diferenças dos resultados são pequenas e como o Prof. Cano utilizou uma série de outras informações para sustentar suas conclusões; elas não devem ser totalmente refutadas. Mesmo porque, elas são defendidas por outros autores como Guimarães Neto (1993), Martine e Diniz (1991) e Guimarães Neto (1995) que diz: "Por fim, vale lembrar que indicadores mais atuais, referentes ao final dos anos 80 e início dos 90 , assinalam a perda de fôlego do processo de desconcentração em favor das regiões menos industrializadas". Além disso, a própria tabela 2.2 demonstra, em sua última coluna, que entre 1995 e 1996 ocorreu um considerável aumento da parcela da região Sudeste no PIB brasileiro, passando de 56,7\% em 1995 para 58,1\% em 1996, contra uma diminuição na parcela de todas as outras regiões do país.

Resta lembrar que o IBGE divulgou, ao final de 1999, as contas regionais do Brasil 1985-1997. Entretanto essas informações não foram utilizadas nessa Tese 
(principalmente as referentes ao ano de 1997) pelo fato das análises já estarem concluídas na época de divulgação dos resultados pelo IBGE.

Outra tendência verificada pelas informações do período 1985/1995 é a alteração na estrutura produtiva do Brasil e de suas economias regionais. A figura $2.12(\mathrm{~b}) \mathrm{e}$ 2.12(c) demonstra a diminuição da participação do setor industrial no Brasil e nas regiões em favor das atividades do setor terciário. Pode-se concluir também que, no período 1985/1995 não ocorreu redução da importância relativa da atividade agrícola em favor das atividades predominantemente urbanas, tendo, inclusive, o setor agrícola voltado a ganhar posição relativa em algumas regiões (figura 2.12(a)).

Sem dúvida, essas transformações ocorridas nos três grandes agregados setorias (agricultura, indústria e serviços) repercutem nos outros subsetores da economia das regiões e do país. Resta saber, portanto, qual o comportamento do setor de agronegócios, o qual engloba partes desses três grandes agregados. Esta é uma das questões tratadas nessa pesquisa. 

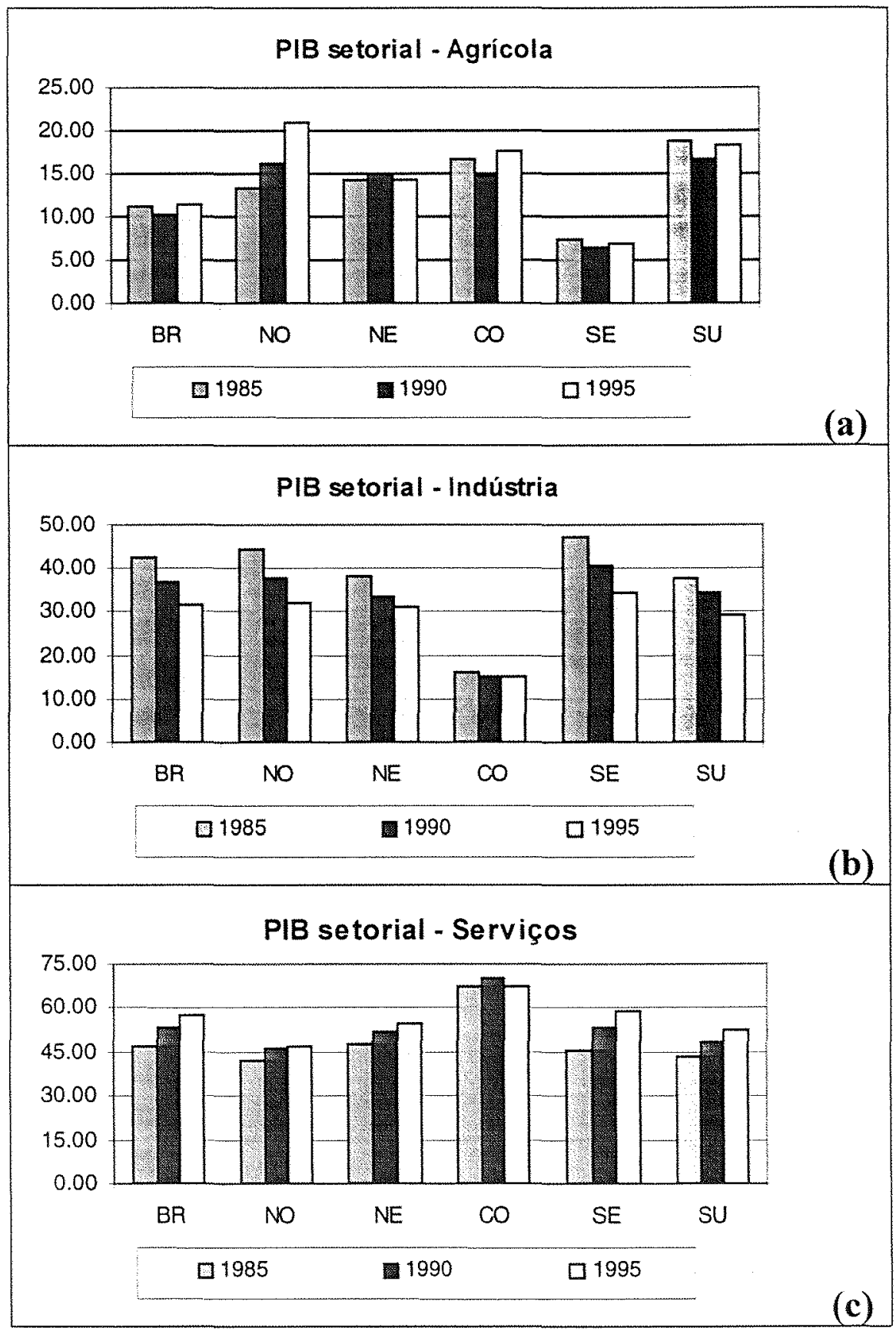

Fonte: Considera e Medina (1998), organizado pelo autor.

Figura 2.12: Participação dos setores no PIB do Brasil e das regióes para os anos de 1985, 1990 e 1995. Em \%. 


\section{CARACTERIZAÇÃO DO AGRONEGÓCIO NO BRASIL}

Este capítulo objetiva principalmente apresentar uma revisão dos trabalhos que analisam a modernização da agricultura brasileira em seus aspectos teóricos e estruturais, ou seja, pretende-se caracterizar o agronegócio brasileiro, com destaque ao setor de processamento de produtos agropecuários. Também será feita uma revisão de alguns conceitos relevantes ao presente estudo O direcionamento da revisão busca informações que serão úteis na interpretação dos resultados que serão obtidos neste estudo.

\subsection{Breve histórico da indústria alimentar no Brasil ${ }^{4}$}

Inicialmente, é importante fazer uma breve recordação do processo de industrialização no Brasil, entretanto, com a atenção voltada principalmente para o comportamento de alguns setores que utilizam, no seu processo produtivo, considerável quantidade de matéria-prima agrícola, e que podem ser considerados como componentes do Agronegócio ou Complexo Agroindustrial Brasileiro.

As primeiras análises sobre o comportamento da indústria de transformação no Brasil, nos remetem até meados do século XIX, sendo que os investimentos eram muito limitados antes desta época; e as necessidades do país atendidas através de importações, principalmente da Grã-Bretanha. Outro fator prejudicial à diversificação das atividades

\footnotetext{
${ }^{4}$ Algumas informações desse tópico foram retirados de PARRÉ, J.L. Proposta da utilização de um modelo de dois setores para análise da geração de excedentes na agroindústria brasileira. Texto para discussão n.10/98, 24p. FEA/CEA/Universidade de Passo Fundo.
} 
econômicas era o próprio processo de desenvolvimento do país, baseado no Modelo Primário Exportador.

Suzigan (1986) é quem melhor caracteriza o desenvolvimento da indústria brasileira durante este período. Para este autor, existem quatro interpretações que relacionam o desenvolvimento industrial brasileiro a partir de uma base agrícolaexportadora:

1) a teoria dos choques adversos: de acordo com esta teoria a industrialização começou como uma resposta às dificuldades impostas às importações pelos choques da Primeira Guerra Mundial, da Grande Depressão da década de 1930 e da Segunda Guerra Mundial.

2) a ótica da industrialização liderada pela expansão das exportações: esta teoria pressupõe a existência linear entre a expansão do setor exportador (principalmente café) e a industrialização.

3) a interpretação baseada no desenvolvimento do capitalismo no Brasil: também chamada de "capitalismo tardio", esta teoria propõe que o crescimento industrial deu-se como parte do processo de desenvolvimento do capitalismo no Brasil.

4) a ótica da industrialização intencionalmente promovida por políticas de governo: esta teoria enfatiza o papel de políticas deliberadas do governo para promover o desenvolvimento industrial, especialmente proteção aduaneira e concessão de incentivos e subsídios à indústria.

Aprofundar-se nesta questão não faz parte dos objetivos deste ítem, entretanto, deve-se destacar o importante papel desempenhado pela indústria de alimentos durante o início da industrialização no país.

Suzigan (1986) cita algumas indústrias que já estavam plenamente estabelecidas no Brasil na década de 1930 ou que estavam recebendo grandes investimentos; em face do aumento da demanda interna. Entre as indústrias que recebiam investimentos nesta 
época destacam-se as que substituíam importações, como as indústrias de cimento, metal-mecânicas, ferro e aço, papel e celulose; produtos de borracha, produtos químicos, farmacêuticos e de perfumaria, óleo de caroço de algodão e têxteis. Haviam indústrias já estabelecidas e que aumentaram seus investimentos, entre elas destacam-se: moagem de trigo, frigoríficos e industrialização de carnes e cervejarias. Pode-se dizer, que a substituição por produção interna, de alguns produtos anteriormente importados, que ocorreu na década de 30 , referiu-se principalmente aos bens de consumo não-duráveis.

Entretanto, a industrialização tornou-se especialmente importante após a Segunda Guerra, quando começou a abranger as faixas de produção de bens de consumo duráveis intermediários e de capital (Viceconti, 1977). Este autor também demonstra que houve uma tendência de concentração setorial da produção; num número menor de empresas, com tamanho médio maior; além de uma certa concentração regional, principalmente no eixo São Paulo - Rio. Percebe-se que a industrialização brasileira apresentou um padrão de baixa absorção de mão-de-obra e uma crescente participação do capital estrangeiro no processo.

Durante as décadas de 50 e 60 ocorreram profundas mudanças estruturais na indústria brasileira, sendo que as indústrias "tradicionais" perderam espaço para setores mais "dinâmicos". Os setores têxtil e de produtos alimentares que em 1949 representavam $40 \%$ da indústria brasileira, tanto em termos do valor adicionado quanto do emprego, tiveram sua participação reduzida pela metade em 1972. (Viceconti, 1977).

A Tabela 3.1 apresenta a taxa de crescimento de alguns ramos da indústria brasileira. Pode-se notar o fraco desempenho do setor de produtos alimentares, bebidas, fumo e têxtil quando comparados à média da indústria nacional.

Rattner (1978) analisa aspectos da concentração, segundo as vendas, na indústria brasileira. De acordo com o autor “... o grau de concentração em alguns dos setoreschave da economia brasileira tem avançado inexoravelmente, constituindo hoje motivo de séria preocupação de empresários nacionais e da opinião pública,...”. Analisando 33 setores industriais no ano de 1977; o autor identificou forte concentração em dez setores 
e relativa concentração em outros dez. O setor de alimentos apresentou relativa concentração, com uma participação das três maiores nas vendas das vinte maiores empresas do setor ficando em $32 \%$.

Ao analisar a estrutura da produção, Rattner (1978) observa que o caráter oligopolista do setor de alimentos deve-se à necessidade de elevado investimento inicial para ter acesso à tecnologia sofisticada e capital-intensiva, da perecibilidade das matérias-primas, do seu alto custo unitário de transporte e, devido à urbanização contínua, o distanciamento cada vez maior das áreas produtoras em direção à fronteira agrícola.

Tabela 3.1: Indústria de transformação - Taxas de crescimento anual segundo período selecionados e ramos industriais (em \%)

\begin{tabular}{lccccc}
\hline \multirow{2}{*}{ Ramos } & \multicolumn{5}{c}{ Períodos } \\
\cline { 2 - 6 } & $1949-52$ & $1952-57$ & $1957-62$ & $1962-67$ & $1967-72$ \\
\hline Minerais não metálicos & 15,0 & 3,0 & 5,9 & 0,3 & 13,9 \\
Metalúrgica & 19,3 & 2,5 & 15,6 & 6,2 & 12,5 \\
Mecânica & 11,6 & 9,9 & 16,5 & 1,4 & 20,5 \\
Material elétrico & 25,1 & 17,7 & 27,0 & 8,1 & 15,4 \\
Material de transporte & 24,5 & 15,3 & 27,0 & 0,0 & 19,3 \\
Papel e papelão & 17,9 & 5,2 & 9,1 & 6,3 & 7,1 \\
Borracha & 19,8 & 6,0 & 15,0 & 6,2 & 13,7 \\
Química & 11,6 & 13,2 & 17,7 & 6,0 & 15,2 \\
Têxtil & 12,4 & $-2,1$ & 8,8 & $-5,0$ & 6,3 \\
Produtos alimentares & 4,4 & 3,2 & 7,5 & 1,8 & 8,7 \\
Bebidas & 9,4 & 6,0 & 4,1 & 0,9 & 7,9 \\
Fumo & 7,1 & 6,2 & 6,6 & $-1,0$ & 5,5 \\
& & & & & \\
Total da indústria & $\mathbf{1 0 , 3}$ & $\mathbf{4 , 4}$ & $\mathbf{1 1 , 9}$ & $\mathbf{2 , 7}$ & $\mathbf{1 2 , 1}$ \\
\end{tabular}

Fonte: Viceconti, 1977.

Obs: 1949 a 1957 - dados obtidos a partir do registro industrial dos anos 1952 e 1957 e do censo industrial de 1950; 1957 a 1972 - Suzigan, W et al. Crescimento industrial recente. Relatório de pesquisa do IPEA, n.26.

Observando dados do Censo Industrial de 1970 para o Brasil, o mesmo autor observou que as empresas médias, que empregam entre 50 e 500 pessoas, embora 
representassem $6 \%$ do número de estabelecimentos, absorviam $46 \%$ dos empregados e geravam 54\% do valor da transformação industrial (VTI); sendo o segmento mais significativo do ramo alimentar. E empresas com mais de 500 empregados $(0,31 \%$ do número de estabelecimentos) geravam $12 \%$ do VTI. Levando à seguinte conclusão: "existe grande número de pequenas empresas sem maior importância econômica; há o predomínio econômico e social das empresas médias e, finalmente, são raras as grandes empresas, sendo, porém, seu significado na economia não desprezível".

No que se refere à demanda, ainda segundo Rattner (1978) os produtos alimentícios industrializados podem ser divididos em dois grupos: a) produtos populares, com demanda inelástica em relação a renda, tais como produtos beneficiados, pães, massas e biscoitos, óleos e gorduras; cujo mercado depende basicamente do crescimento do nível de emprego. b) produtos consumidos pelas famílias de maior nível de renda, tais como produtos conservados, doces, geléias e produtos derivados de cacau, legumes em conserva, pescado industrializado e laticínios; cujo mercado depende do crescimento do emprego e da renda, bem como da distribuição desta.

Ao final dos anos 70 a indústria de processamento de alimentos no Brasil apresentava as seguintes características, segundo Bertero(1978):

- a grande maioria da população consome alimentos com um mínimo de processamento e que são entregues ao consumo in natura.

- a indústria de alimentos apresentou na década de 70 uma taxa de crescimento moderada, mas segura, com poucas oscilações. Isto manteve constante as taxas de retorno e a lucratividade.

- a indústria de alimentos apresenta baixa densidade tecnológica, quando comparada a outros setores, com poucas despesas em pesquisa e desenvolvimento.

- os sub-setores de processamento de carne, massas e biscoitos, frutas e legumes e óleos vegetais, realizaram inovações que buscavam introduzir novos produtos, o aumento da 
produção, da produtividade, a melhoria dos padrões de higiene e o aprimoramento da qualidade dos produtos.

Com relação às mudanças recentes na estrutura industrial brasileira, algumas informações são apresentadas nas tabelas 3.2 e 3.3. A primeira tabela apresenta índices de crescimento da produção industrial do Brasil para o período 1980/95. O crescimento médio entre $1980 / 95$ foi de $8,6 \%$, sendo que na primeira metade da década de 80 (1980/85) houve uma queda de 3,1\% na produção industrial do Brasil; entre 1985/89 houve um crescimento de $11,7 \%$; e entre 1989/95 observa-se um pequeno crescimento de $0,4 \%$. Ocorreu, portanto, um fraco desempenho do total de indústrias do país.

Tabela 3.2: Índices do crescimento da produção industrial - Brasil, 1980/95.

\begin{tabular}{|c|c|c|c|c|}
\hline & $1980 / 95$ & $1980 / 85$ & $1985 / 89$ & $1989 / 95$ \\
\hline \multicolumn{5}{|l|}{ Bens de consumo não-durável } \\
\hline Farmacêuticos & 124,1 & 109,2 & 113,0 & 101,0 \\
\hline Perfumes, sabonetes, velas & 190,9 & 122,0 & 138,4 & 113,0 \\
\hline Produtos plásticos & 100,9 & 90,1 & 121,5 & 92,2 \\
\hline Têxteis & 81,0 & 88,6 & 106,5 & 85,8 \\
\hline Vestuário e calçados & 60,3 & 96,7 & 92,1 & 67,7 \\
\hline Produtos alimentícios & 131,2 & 106,9 & 106,0 & 115,8 \\
\hline Bebidas & 188,8 & 94,6 & 139,7 & 142,8 \\
\hline Fumo & 150,8 & 123,0 & 116,4 & 105,3 \\
\hline \multicolumn{5}{|l|}{ Bens intermediários } \\
\hline Minerais não-metálicos & 92,2 & 83,1 & 119,4 & 93,0 \\
\hline Metalúrgica & 104,3 & 95,1 & 114,2 & 96,0 \\
\hline Papel & 122,1 & 115,5 & 119,0 & 105,8 \\
\hline Borracha & 119,1 & 97,5 & 117,9 & 106,2 \\
\hline Química & 124,1 & 122,4 & 103,6 & 94,0 \\
\hline \multicolumn{5}{|c|}{ Consumo durável e bens de capital } \\
\hline Mecânica & 84,4 & 75,5 & 121,8 & 91,8 \\
\hline Material elétrico & 137,3 & 93,9 & 121,0 & 120,8 \\
\hline Material de transporte & 99,6 & 81,6 & 107,2 & 113,9 \\
\hline Total Ind. de transformação & 108,6 & 96,9 & 111,7 & 100,4 \\
\hline
\end{tabular}

Fonte: Cano (1998); dados obtidos de FIBGE: Contas Nacionais e Produção Industrial Física. 
A tabela 3.2, apresenta, também, informações sobre o crescimento de alguns ramos industriais do Brasil, entre eles, estão os ligados ao agronegócio os quais apresentaram comportamento variado durante o período 1980/95. A indústria têxtil apresentou uma queda de crescimento médio de 19,0\% no período, vestuário e calçados caíram quase $40,0 \%$, a maior queda entre todos os ramos analisados por Cano. Por outro lado, as industrias de alimentação, de bebidas e do fumo apresentaram boas taxas de crescimento no período, respectivamente, $31,2 \%, 88,8 \%$ e $50,8 \%$.

As explicações apresentadas por Cano (1998) para o comportamento das taxas de crescimento desses ramos industriais vão desde o aumento do processo de urbanização em algumas regiões do país, o que causou um crescimento da indústria de alimentos até os incentivos fiscais e financeiros fornecidos por alguns estados para a indústria do fumo. A queda no crescimento das indústrias têxtil e vestuário e calçados é comentada pelo autor: "em que pese o fato de que a forte (e inexplicada) redução de seus índices de crescimento (...) possa ocultar alta informalização e provável sonegação, ainda que tenham sido muito afetados pelas importações. Neste caso, portanto, o fenômeno poderia ser muito mais de caráter estatístico do que efetivo".

Baer (1995) apresenta informações sobre as mudanças na estrutura industrial do Brasil (tabela 3.3), onde pode-se observar que alguns setores industriais ligados ao agronegócio perderam importância entre os anos de 1949 a 1980 (produtos alimentícios, por exemplo, caiu de 19,7\% para 10,0\%); entretanto, ocorreu uma recuperação na participação desses produtos entre 1980 e 1992. De certa forma, os resultados de Baer confirmam as taxas de crescimento obtidas por Cano.

Nesse sentido, os produtos que apresentaram taxas de crescimento positivas no período 1980/95, aumentaram sua participação no valor total da produção industrial brasileira entre 1980 e 1992, como é o caso das industrias de alimentos, de bebidas e de fumo; e as que apresentaram diminuição em suas taxas de crescimento, diminuíram sua participação no valor da produção industrial, como ocorreu com as industrias têxtil e de vestuário e calçados. 
Tabela 3.3: Mudanças na estrutura industrial - Brasil, 1949-92: valor bruto agregado $(\%)$.

\begin{tabular}{lccccc}
\hline & 1949 & 1963 & 1975 & 1980 & 1992 \\
\hline Minerais não metálicos & 7,4 & 5,2 & 6,2 & 5,8 & 4,7 \\
Produtos de metal & 9,4 & 12,0 & 12,6 & 11,5 & 11,9 \\
Maquinário & 2,2 & 3,2 & 10,3 & 10,1 & 12,5 \\
Equipamento elétrico & 1,7 & 6,1 & 5,8 & 6,3 & 6,8 \\
Equipamento de transporte & 2,3 & 10,5 & 6,3 & 7,6 & 7,1 \\
Produtos de madeira & 6,1 & 4,0 & 2,9 & 2,7 & 1,2 \\
Móveis & - & - & 2,0 & 1,8 & 0,9 \\
Produtos de papel & 2,1 & 2,9 & 2,5 & 3,0 & 3,7 \\
Produtos de borracha & 2,0 & 1,9 & 1,7 & 1,3 & 1,4 \\
Produtos de couro & 1,3 & 0,7 & 0,5 & 0,6 & 0,5 \\
Produtos químicos & - & - & 12,0 & 14,7 & 13,0 \\
Farmacêuticos & 9,4 & 15,5 & 2,5 & 1,6 & 2,3 \\
Perfumes, sabonetes, velas & - & - & 1,2 & 0,9 & 1,1 \\
Produtos plásticos & - & - & 2,2 & 2,4 & 2,2 \\
Têxteis & 20,1 & 11,6 & 6,1 & 6,4 & 4,6 \\
Vestuário e calçados & 4,3 & 3,6 & 3,8 & 4,8 & 3,2 \\
Produtos alimentícios & 19,7 & 14,1 & 11,3 & 10,0 & 13,6 \\
Bebidas & 4,3 & 3,2 & 1,8 & 1,2 & 2,1 \\
Fumo & 1,6 & 1,6 & 1,0 & 0,7 & 1,4 \\
Impressão e material gráfico & 4,2 & 2,5 & 3,6 & 2,6 & 2,6 \\
Diversos & 1,9 & 1,4 & 3,7 & 4,0 & 3,2 \\
& & & & & \\
Total & 100,0 & 100,0 & 100,0 & 100,0 & 100,0 \\
\hline Fonte: Bar
\end{tabular}

Fonte: Baer (1995); dados obtidos em IBGE, Censos Industriais e Perspectivas da economia brasileira 1993, R.J.-IPEA, 1993, p.709.

Torna-se importante analisar as tendências recentes do consumo de alimentos no Brasil, que sofreu um aumento em certos segmentos influenciado pelo Plano Real. A tabela 3.4 apresenta o dinamismo do setor nos últimos anos. Pode-se notar que, os alimentos industrializados e com maior valor agregado, como chocolates e iogurtes têm apresentado aumento do consumo. Por outro lado, o consumo de arroz, produto considerado básico, apresenta-se estável e com uma pequena queda no ano de 1996. De modo geral, o aumento de consumo reflete-se em todos os produtos listados. 
Este dinamismo também reflete-se no faturamento da indústria brasileira de alimentos, que passou de US\$ 28 bilhões em 1985 para US $\$ 53$ bilhões em 1995, um crescimento de quase 90\% na década; estes dados são apresentados na tabela 3.5. Esta tabela também confirma o grande crescimento do segmento de laticínios, que cresceu quase 2,5 vezes no período. A indústria de carnes apresenta uma taxa de crescimento do faturamento de $29 \%$, bem abaixo da média total. Este comportamento provocou uma perda de importância do segmento em relação ao faturamento global da indústria de alimentos brasileira.

Tabela 3.4: Consumo de alimentos no Brasil, 1993=100. 1994/1997.

\begin{tabular}{lcccc}
\hline & 1994 & 1995 & 1996 & $1997^{*}$ \\
\cline { 2 - 5 } Massas & 108 & 118 & 124 & 142 \\
Trigo & 105 & 109 & 104 & 113 \\
Óleo de soja & 105 & 111 & 114 & 119 \\
Margarina & 106 & 113 & 119 & 123 \\
Arroz em casca & 101 & 102 & 95 & - \\
Chocolates & 115 & 141 & 143 & - \\
Iogurtes & 139 & 242 & 265 & 273 \\
$*$ previsão & & & & \\
\hline
\end{tabular}

Fonte: Cebrap (1997).

Tabela 3.5: Evolução do faturamento de segmentos selecionados da indústria brasileira de alimentos, em bilhões de dólares e percentagens, 1985 e 1995.

Laticínios

Café, chá e cereais benef.

Óleos e gorduras

Derivados de trigo

Derivados de carnes

Outros

Açucares

Derivados de frutas e veget.

Chocolate, cacau e balas

Conservas de pescados

Total

Fonte: Cebrap 5 .

\begin{tabular}{ccccc}
\hline \multicolumn{1}{c}{1985} & \multicolumn{3}{c}{1995} & $95 / 85$ \\
\hline US\$ bi & $\%$ & US\$ bi & $\%$ & $\%$ \\
\hline 2,85 & 10,1 & 9,92 & 18,7 & 248 \\
4,73 & 16,8 & 8,32 & 15,7 & 76 \\
4,86 & 17,2 & 6,87 & 13,0 & 41 \\
2,29 & 8,1 & 6,66 & 12,6 & 191 \\
4,88 & 17,3 & 6,3 & 11,9 & 29 \\
1,73 & 6,1 & 4,53 & 8,6 & 162 \\
2,66 & 9,4 & 4,18 & 7,9 & 57 \\
2,53 & 9,0 & 3,95 & 7,5 & 56 \\
1,29 & 4,6 & 1,81 & 3,4 & 40 \\
0,36 & 1,3 & 0,44 & 0,8 & 22 \\
$\mathbf{2 8 , 1 8}$ & $\mathbf{1 0 0 , 0}$ & $\mathbf{5 2 , 9 8}$ & $\mathbf{1 0 0 , 0}$ & $\mathbf{8 8}$ \\
\hline
\end{tabular}

\footnotetext{
${ }^{5} \mathrm{Na}$ composição das tabelas 3.4 e 3.5 , os pesquisadores do Cebrap utilizaram as seguintes fontes: Abima, Abitrigo, Abiove, ABM, Abicab e Abrini na tabela 3.4; e ABIA e Agroanalysis na tabela 3.5.
} 


\subsection{O enfoque do agronegócio}

Os trabalhos revistos na seção anterior, baseados principalmente em informações do Censo Industrial, analisam os setores industriais, inclusive a indústria de alimentos, de forma isolada, não dando a devida importância às suas ligações com outros setores da economia.

Nesta seção, a análise passa a envolver trabalhos que, não apenas utilizam uma nova nomenclatura, mas, principalmente, analisam o setor de produção de fibras e alimentos de forma diferenciada, dando-lhe maior importância econômica e estratégica e tornando-o um setor específico da economia, chamado de Complexo Agroindustrial ou Agronegócio Brasileiro. Em virtude disto, e para harmonizar a nomenclatura utilizada nesta pesquisa, alguns conceitos devem ser expostos.

Vários autores, no Brasil e no exterior, realizaram estudos e apresentaram seus conceitos sobre o agronegócio, como por exemplo Davis e Golberg (1957); Malassis (1969); Hoffmann et al. (1985); Delgado (1985); Farina (1988); Müller (1989); Araújo et al. (1990); Fundação Seade (1990); Kageyama et al. (1990); Streeter et al. (1991); Barry et al. (1992); Lauschner (1995); Wilkinson (1995); Kageyama \& Graziano da Silva (1996); Furtuoso (1998); Furtuoso, Barros e Guilhoto (1998); Montoya \& Guilhoto (1999). A maioria desses autores serão revisados a seguir.

O primeiro estudo utilizando o termo agribusiness foi desenvolvido na Universidade de Harvard em 1957; resultando no livro "Concept of Agribusiness" de autoria dos professores John Davis e Ray Golberg. Neste livro, o conceito de Agribusiness é:

"... a soma total das operações associadas à produção e distribuição de insumos agrícolas, das operações de produção nas unidades agrícolas, do armazenamento, processamento e distribuição dos produtos agricolas, e também dos itens derivados". 
Sem dúvida, esta definição é bastante adequada à realidade vivida pelo setor agroalimentar e de produção de fibras vegetais no Brasil, onde as atividades são diferenciadas e interligadas apresentando um setor que produz insumos, máquinas e equipamentos agrícolas ("antes da porteira"); um setor de produção agropecuária ("dentro da porteira"); e um setor que atua "depois da porteira" que envolve o processamento e o acondicionamento (agroindústria), a armazenagem e a distribuição. Fazem parte deste complexo, além dos agentes já citados, o governo, os mercados, as entidades comerciais, financeiras e de serviços; que exercem influência no fluxo dos produtos.

Existe uma interdependência muito forte entre todos os agentes que atuam no agronegócio, levando a um enfoque sistêmico. A visão sistêmica ajuda na tomada de decisão; pois todas as operações envolvidas no sistema produtivo influenciam a eficiência do processo e, portanto, afetam a eficiência de cada atividade isolada.

Nesse sentido, a agroindústria faz parte do Complexo Agroindustrial e, basicamente, é o setor que transforma ou processa matérias-primas agropecuárias em produtos elaborados, adicionando valor ao produto. Neste trabalho, agroindústria também será denominado de setor de processamento de alimentos.

Vale destacar, a essa altura, que o termo agroindústria tem sido definido de diversas maneiras, ou seja, compreendendo diferentes ramos industriais; o que acaba por definir diversos graus de abrangência para o conceito.

Segundo Hoffmann et al. (1985) para ser caracterizado como agroindústria, o estabelecimento comercial deve, evidentemente, utilizar matéria-prima de origem agrícola. Porém, surge um problema quanto ao grau de beneficiamento desta matériaprima. "Por exemplo, será considerada como agroindústria apenas aquela que efetua a primeira transformação da matéria-prima (como a secagem, ou a limpeza, ou o beneficiamento), ou se incluirá também aquela que, utilizando a matéria-prima já preparada, efetua a sua transformação em algum produto acabado ou semi-acabado?". Os autores citam alguns exemplos como: beneficiamento do café $\times$ torrefação e 
moagem; a produção de óleos vegetais em bruto $\times$ refinação de óleos; produção de celulose $\times$ produção de papel; obtenção de madeira serrada $\times$ produção de artefatos de madeira; beneficiamento de fibras vegetais e animais $\times$ fiação; etc.

Os autores concluem que, apesar de teoricamente ser mais adequado considerar apenas a primeira transformação sofrida pelo produto agrícola; deve ser considerado que é comum o caso de um mesmo estabelecimento industrial efetuar as duas fases de transformação, ou seja, "pode existir um certo grau de integração na indústria que não permite isolar, na prática, somente a primeira fase de beneficiamento da matéria-prima agricola”. Portanto, segundo Hoffmann et al. (1985) “...a formulação de um conceito puro de agroindústria pode ser factivel apenas num plano teórico, porém sem possibilidade de operacionalização no estudo de casos concretos, especialmente quando se trata de um estudo abrangente baseado em dados secundários".

Um estudo que utiliza a definição de agroindústria considerando apenas o beneficiamento dos produtos agrícolas em sua primeira etapa foi realizado pela Fundação Seade (1990), numa pesquisa sobre as causas do desenvolvimento da agroindústria no Estado de São Paulo.

O termo agroindústria é definido por Lauschner (1995), de dois modos:

- em sentido amplo, é “ a unidade produtiva que transforma o produto agropecuário natural ou manufaturado para a sua utilização intermediária ou final ";

- em sentido restrito, é " a unidade produtiva que transforma para a utilização intermediária ou final o produto agropecuário e seus subprodutos não manufaturados, com aquisição direta do produtor rural de um mínimo de $25 \%$ do valor total dos insumos utilizados".

Essa separação feita por Lauschner entre agroindústria ampla e restrita leva ao mesmo problema discutido por Hoffmann et al., ou seja, na prática a definição de agroindústria em sentido restrito proposta por Lauschner sofre o impacto dos preços 
relativos e pode não refletir a real importância da matéria-prima agrícola dentro do processo produtivo da agroindústria.

Representando uma linha de estudos com forte enfoque teórico-conceitualmetodológico sobre o relacionamento agricultura-indústria no Brasil estão os trabalhos de Delgado (1985); Farina (1988) ; Müller (1989); Kageyama et al. (1990); e Kageyama \& Graziano da Silva (1996).

Delgado (1985), ao analisar o padrão de desenvolvimento da agricultura brasileira a partir da metade da década de 60 , identifica um conceito-chave que caracteriza esse padrão; a saber, a integração de capitais; entendida como um processo de "centralização de capitais industriais, bancários, agrários, etc., que por sua vez fundir-se-iam em sociedades anônimas, condomínios, cooperativas rurais e, ainda, empresas de responsabilidade limitada, integradas verticalmente (agroindustriais ou agro-comerciais)". Nesse sentido, segundo o autor, o sistema financeiro converte-se num elo relacionando a agricultura e a economia num sentido mais amplo, fazendo com que a primeira movimente-se de acordo com a segunda.

A pesquisa desenvolvida por Farina (1988) incorpora os elementos teóricos da Organização Industrial, como as teorias de crescimento da firma e os tipos de estruturas de mercado, no estudo do sistema agroindustrial de alimentos (SAA). O SAA é definido pela autora como "a cadeia que se inicia na produção agrícola, passa por um processo de transformação industrial e, através de uma rede de distribuição, chega ao consumidor final". A autora parte da hipótese de que é o segmento industrial, particularmente as grandes empresas nacionais e estrangeiras, que definem a dinâmica do SAA. E que o crescimento da indústria alimentar está condicionado ao crescimento da renda e do emprego; sendo que o consumo cresce com a renda até um nível de saturação. Estes aspectos determinam um limite ao crescimento da indústria alimentar, dado pelo crescimento vegetativo da população e da renda. As alternativas seriam, então,

\footnotetext{
${ }^{6}$ Apesar de os trabalhos de Müller; de Kageyama et al.; e de Kageyama \& Graziano revisados nesta pesquisa apresentarem datas posteriores ao de Farina, estes trabalhos tiveram publicações anteriores; por essa razão Farina já faz citações das idéias desses autores.
} 
criar novas formas de consumo e novos consumidores, levando à diversificação e diferenciação da linha de produtos.

Para Müller (1989) é importante contextualizar historicamente o processo de surgimento do complexo agroindustrial (CAI) no Brasil, o qual seria o principal vetor da "modernização agrária" ocorrida no país. Para o autor, ao abandonar-se o enfoque setorial dado à agricultura, valorizando-se a interdependência entre agricultura e indústria, determina-se o fim do caráter autônomo da agricultura e a diminuição da capacidade decisória dos grupos sociais rurais. Ou seja, considerar o CAI como unidade de análise significa incluir a agricultura na dinâmica industrial e financeira, porém preservando-se suas peculiaridades.

A idéia central de Müller (1989) é de que "a constituição do complexo agroindustrial é produto da modernização" (da agricultura) “... e sua manutenção $e$ expansão constitui o principal vetor da modernização". Ou seja, a constituição do CAI requer a integração da agricultura com a indústria situada à montante, que é chamado de industrialização da agricultura, e com a indústria situada à jusante, que seria a agroindustrialização. E essa integração representaria, na visão do autor, a modernização (tecnico-econômica) da agricultura, ou seja, a passagem do predomínio do tradicional para o predomínio do moderno. A partir daí (da constituição do CAI), a manutenção e expansão do CAI passam a constituir o principal vetor da modernização da agricultura. Tem-se então, uma dinâmica conjunta da indústria para a agricultura-agriculturaagroindustria.

Na opinião de Kageyama \& Graziano da Silva (1996) "não se deve confundir os conceitos de modernização, industrialização da agricultura e constituição dos complexos agroindustriais, que são distintos e temporalmente identificáveis". A princípio parece haver grandes diferenças conceituais entre esses autores e Müller (1989), porém, ao analisar-se os trabalhos, percebe-se que a diferença está na ênfase dada ao assunto. Müller (1989) chama a atenção para a integração contemporânea que ocorre no processo de constituição do CAI; por outro lado, Kageyama et al. enfatiza que 
existe uma sucessão de etapas, determinadas por períodos de tempo, que levarão à constituição dos CAI's. A principal diferença está no fato de que Müller afirma que o processo levará à constituição de um CAI, enquanto Kageyama \& Graziano da Silva afirmam que "A constituição dos CAI's e a industrialização da agricultura passam a ser os novos determinantes da dinâmica da agricultura"

Nesse sentido Kageyama et al. (1990) propõem uma classificação dos CAI's em quatro categorias: CAI's completos, CAI's incompletos, agricultura modernizada e agricultura tradicional.

Os CAI's completos são os segmentos mais modernos e industrializados, apresentando relações consolidadas tanto "para trás" quanto "para frente" do setor de produção agropecuária.

Os CAI's incompletos apresentam forte integração "para frente" da produção agrícola (com as agroindústrias), mas não apresentam a mesma especificidade de vínculos com a indústria para a agricultura.

A agricultura modernizada não apresenta status de complexos por carecer de relações específicas tanto "para frente" quanto "para trás". Entretanto, utilizam e dependem dos meios de produção de origem industrial.

A agricultura tradicional ou artesanal inclui as atividades agrícolas não modernizadas e que apresentam fracas ou inexistentes relações com a indústria.

As idéias de Kageyama et al. (1990) podem ser resumidas na frase: "Não existe apenas uma agricultura, mas vários complexos agroindustriais e a dinâmica desses segmentos da agricultura é a dos complexos. Em todos eles existe um elemento aglutinador administrador, que são as políticas do Estado."

Representando uma linha de estudos preocupados em desenvolver uma teoria para dimensionar o agronegócio no Brasil ou apresentar resultados sobre a evolução desse setor, em termos de concentração e competitividade estão os trabalhos de Araújo 
et. al. (1990); Wilkinson (1995); Lauschner (1995); Furtuoso (1998); Furtuoso, Barros e Guilhoto (1998); Montoya \& Guilhoto (1999).

Araújo et. al. (1990) publicaram um trabalho que reúne uma considerável quantidade de dados e informações sobre o Complexo Agroindustrial Brasileiro. Os autores apresentam uma classificação dos elementos que constituem o agronegócio, sendo que, para esta revisão, é importante destacar a constituição do setor de processamento e transformação. As indústrias que constituem este setor são as seguintes:

- "Alimentos; têxteis; vestuário, calçado e madeira; bebidas; álcool; papel e papelão; fumo; óleos e essências".

Através da análise da matriz insumo-produto brasileira, os autores demonstraram a importância do Complexo Agroindustrial na economia do país, principalmente no que se refere à geração de empregos e nas relações "para frente" e "para trás" com os outros setores da economia. Araújo et. al. (1990) também determinaram a dimensão econômica do "agribusiness" brasileiro para o ano de 1980, decompostos em seus agregados, chegando às seguintes participações no total do agronegócio: os insumos e bens de produção para a agricultura participaram com 11,4\% do total do agronegócio; o valor da produção do setor agropecuário representou $27,8 \%$; o setor de processamento participou com 30,5\%; e o setor de distribuição participou com 30,3\%. O total do "agribusiness" brasileiro, para esses autores, em 1980, representou 32,0\% do PIB brasileiro.

Ao analisar o setor de processamento, os autores observam que o seu desempenho " está estreitamente relacionado com o grau de articulação mantido com o setor agropecuário. Para operar com economia de escala, as empresas requerem matérias-primas e produtos em quantidade, qualidade e custo compatível ". Isto faz com que a agricultura sofra uma pressão para se modernizar tecnologicamente.

Araújo et. al. (1990) também comentam o processo de concentração que é verificado nos mercados do setor de transformação dos produtos agropecuários, o qual, segundo eles, é decorrente da grande necessidade de capitais e capacidade gerencial para 
administrar o processo; tornando-se barreiras à participação das empresas no ramo agroindustrial.

Destaque especial é dado às indústrias de alimentos, que " trata-se de um setor estratégico para a viabilização do desenvolvimento econômico e social do País ", segundo Araújo et al (1990). Observa-se que existe uma concentração regional desta indústria, com 43,4\% das unidades instaladas localizando-se na região Sudeste, seguida da região Norte/Nordeste com $28,8 \%$ e da região Sul com $19 \%$, restando $8,8 \%$ das unidades que ficam na região Centro-Oeste. Os setores que apresentam maior expressão na composição da indústria de alimentos (1982-84) são os de abate de animais e preparação de carnes (16\%), fabricação e refino de açucar (13\%), laticínios (12\%), panificação e fabricação de massas alimentícias (8\%), óleos e gorduras vegetais para alimentação (8\%), conservas de frutas e legumes $(8 \%)$ e beneficiamento e industrialização de café (6\%). Finalmente, deve-se considerar que a indústria alimentícia brasileira apresenta relativa defasagem tecnológica, que se constitui num dos motivos que prejudicam o crescimento das exportações.

Wilkinson (1995) realizou amplo estudo para determinar a competitividade do complexo agroindustrial brasileiro "no contexto dos novos padrões de concorrência em nível internacional com a finalidade de identificar os indicadores relevantes de competitividade e propor um conjunto de políticas para o setor".

A análise realizada pelo autor baseou-se numa série de estudos que abordaram os setores de café, suco de laranja, óleos (com ênfase no de soja), carnes e produtos lácteos. Segundo Wilkinson, a modernização da agroindústria brasileira foi condicionada por fatores internacionais como a crise do petróleo, e por políticas internas do país como : "a) a busca de maiores niveis de auto-suficiência em recursos estratégicos e de poupança de divisas; b) aumento das receitas provenientes de exportação; e c) controle da inflação". Estas prioridades macroeconômicas do Brasil no início dos anos 70 resultaram no surgimento do novo complexo sucro-alcooleiro, na rápida expansão do complexo trigo e no estímulo a produtos de clima temperado (maçã, olericultura). A 
preocupação em exportar levou ao aumento da produção de suco de laranja e na evolução das cadeias de soja e carnes brancas.

Wilkinson (1995) conclui que "a manutenção da competitividade dos principais complexos alimentares brasileiros exige novos padrões de (auto) regulação dos atores. No caso dos setores anteriormente tutelados pelo Estado - café e leite - o desafio é maior. Mas, mesmo nos setores de sucos e carnes, as pressões de competitividade em mercados adversos acirram os conflitos entre fornecedores de matéria-prima $e$ indústrias". O autor também demonstra preocupação com a realocação geográfica da agroindústria do país, no sentido de que há uma "necessidade de ajudar a dinâmica da agroindústria a uma realocação geográfica da fronteira que coloca em questão padrões anteriores de gestão...".

A obra de Lauschner (1995) apresenta importantes reflexões sobre os conceitos que envolvem o agronegócio ou, como o próprio autor define, complexo rural. As principais contribuições desse autor foram: a diferenciação de agroindústria em sentido amplo e em sentido restrito (já comentado nesse tópico); a interpretação das tendências da evolução dos complexos rurais para os países em desenvolvimento; e, talvez o principal, a apresentação de um método científico para calcular o complexo rural no Brasil (adotando parcialmente a metodologia de Malassis, 1969).

Com relação às tendências do complexo rural (ou agronegócio), o autor destaca "três características, que parecem ser estruturais e, portanto, generalizáveis para países desenvolvidos e, como tendência, para os países em desenvolvimento"; as quais resumidamente são: $1^{\text {a }}$ tendência: Participação crescente dos insumos rurais - $\mathrm{O}$ agregado I ou montante do complexo rural tende a ser sempre mais representativo no valor da produção vendida pelos produtores rurais, por causa do desenvolvimento tecnológico e da divisão do trabalho; $2^{a}$ tendência: Diminuição relativa de renda dos agricultores - A tendência histórica da evolução do complexo rural (dos EUA, baseado em dados de Davis \& Goldberg, 1957 e Goldberg, 1968) mostra que a montante (agregado I) do complexo aumentou o valor da produção 32,0 vezes entre 1910 e 1965; a 
jusante (agregado III) incrementou sua renda 32,9 vezes entre 1910 e 1965, mas a renda dos produtores rurais (agregado II) cresceu, nesse período, somente 3,3 vezes. "Uma das prováveis causas ... é a exploração dos produtores rurais nos países desenvolvidos ... provocada pela estrutura de mercado dos diversos agregados do complexo"; $3^{\mathrm{a}}$ tendência: Importância crescente da agroindústria - O agregado III ou jusante do complexo rural reflete a mudança radical ocorrida na estrutura de consumo da população que exige sempre maior industrialização e diversificação de alimentos, além do fato de ocorrer um crescimento da população urbana. "assim, a agroindústria passa a ser sempre mais importante na medida em que se moderniza o complexo rural". A metodologia apresentada por Lauschner (1995) para o dimensionamento do agronegócio será discutida no capítulo 4 desta tese.

As pesquisas de Furtuoso (1998) e de Furtuoso, Barros e Guilhoto (1998) tiveram como principal objetivo dimensionar o produto interno bruto do complexo agroindustrial brasileiro, tendo como base as matrizes insumo-produto do Brasil para os anos de 1980a 1994. Um resumo dos resultados obtidos por esses autores é apresentado na tabela 3.6, que apresenta a participação do CAI na composição do PIB do Brasil.

Tabela 3.6: Produto interno bruto a custo de fatores do complexo agroindustrial. Brasil 1980-1994. (em porcentagem - \%).

\begin{tabular}{llllllll}
\hline & 1980 & 1985 & 1990 & 1991 & 1992 & 1993 & 1994 \\
\hline Versão 1 & 27,14 & 29,46 & 23,51 & 22,71 & 24,75 & 25,55 & 26,35 \\
Versão 2 & 30,48 & 33,37 & 27,45 & 26,65 & 28,93 & 30,22 & 30,30 \\
Versão 3 & 33,13 & 36,15 & 29,70 & 28,46 & 30,73 & 31,98 & 31,71 \\
& & & & & & & \\
PIB & 100,00 & 100,00 & 100,00 & 100,00 & 100,00 & 100,00 & 100,00 \\
\hline
\end{tabular}

Fonte: Furtuoso, Barros e Guilhoto (1998).

Uma contribuição importante dos autores foi a utilização do instrumental de insumo-produto para determinar as principais interligações da atividade agropecuária com os demais setores produtivos do país, quanto à compra de produtos e insumos (os efeitos diretos e indiretos para trás na atividade agrícola). Isso possibilitou que fossem 
adotadas três versões de indústria de base agrícola, gerando, portanto, três versões ou composições para o CAI. A versão 1 engloba as atividades correspondentes aos setores: fabricação de elementos químicos, indústria do café, beneficiamento de produtos vegetais, abate de animais, indústria de laticínios, fabricação de açúcar e fabricação de óleos vegetais; a versão 2 adiciona à versão 1 os segmentos madeira e mobiliário e fabricação de outros produtos alimentares; e a versão 3 adiciona à versão 2 o setor de indústria têxtil.

Montoya \& Guilhoto (1999) interessados em "compreender melhor o contexto econômico global que está presente para o agricultor familiar", mensuraram a estrutura do agronegócio brasileiro utilizando-se das matrizes insumo-produto para o Brasil dos anos de 1959 a 1995. Um resumo dos resultados obtidos por esses autores é apresentado na tabela 3.7 .

Tabela 3.7: Participação relativa e em dólares* do agronegócio no Produto Interno Brasileiro. Período 1959 a 1995.

\begin{tabular}{lcccc}
\hline & \multicolumn{2}{c}{ Agronegócio } & \multicolumn{2}{c}{ PIB brasileiro } \\
\cline { 2 - 5 } Anos & US\$ Milhões & Percentual & US\$ Milhões & Percentual \\
\hline 1959 & 6805 & 52,76 & 12899 & 100,00 \\
1970 & 13985 & 42,80 & 32673 & 100,00 \\
1975 & 39921 & 39,44 & 101207 & 100,00 \\
1980 & 77297 & 36,41 & 212309 & 100,00 \\
1985 & 77479 & 38,89 & 199249 & 100,00 \\
1990 & 143894 & 36,47 & 394562 & 100,00 \\
1995 & 197881 & 33,29 & 594391 & 100,00 \\
\hline
\end{tabular}

Fonte: Montoya \& Guilhoto (1999). * calculado pela taxa média de câmbio.

Pode-se observar, através dos resultados obtidos pelos autores, que a participação relativa do agronegócio no PIB brasileiro apresenta uma tendência gradativa à diminuição, "em virtude da expansão do setor de serviços e de outros complexos industriais do pais". Entretanto, esses resultados também indicam que houve um aumento da renda total do agronegócio brasileiro, passando de US\$ 6.850 milhões em 1959 para US\$ 197.881 milhões em 1995. 


\subsection{Considerações finais}

Esse capítulo mostrou que existem diferentes maneiras de se analisar as questões referentes ao agronegócio no Brasil. Diversos tipos de enfoque e várias formas de caracterizar o complexo agroindustrial, principalmente o segmento de agroindústria e distribuição final (ou agregado II).

A forma como foi elaborada a revisão, procurando agrupar linhas de pesquisa semelhantes, possibilitou determinar 3 tipos de análises as quais, a meu ver, são complementares e apresentam uma sequiência no tempo: Inicia-se com os estudos que analisam tanto a agricultura quanto a indústria de alimentos como setores isolados e autônomos, com dinâmica própria; a seguir surge uma linha de estudos com forte enfoque teórico-conceitual-metodológico sobre o relacionamento agricultura-indústria no Brasil; e mais recentemente, surge uma linha de estudos preocupados em desenvolver uma teoria para dimensionar o agronegócio no Brasil ou apresentar resultados sobre a evolução desse setor.

Percebe-se, então, que a linha de pesquisa desenvolvida nessa tese, enquadra-se nesse último grupo. Porém, assume uma característica própria ao procurar analisar o agronegócio das regiões do Brasil, tema, até aqui, pouco comentado dentro da literatura referente ao assunto; como essa revisão demonstrou. 


\section{METODOLOGIA}

O referencial metodológico dessa pesquisa, para atender aos objetivos propostos, está dividido em duas partes: uma apresentando a teoria das matrizes de insumo-produto interregionais, sua obtenção e atualização e a outra parte deste capítulo tratará do método de dimensionamento do agronegócio para o Brasil e suas macrorregiões e os impactos que este setor pode causar na economia das macrorregiões.

\subsection{O Modelo insumo-produto}

Wassily Leontief foi o pesquisador que publicou a primeira tabela de relações intersetoriais para uma economia nacional. Os trabalhos de Leontief nessa área inciaram-se em Harvard, em 1931. Cinco anos depois, foram apresentadas, pela primeira vez, suas idéias básicas, no artigo Quantitative input-output relations in the economic system of the United States (Leontief,1936). Em 1941 foi publicado o primeiro livro de Leontief, contendo a matriz de insumo-produto da economia americana, para os anos de 1919-1929 (Leontief,1941); sendo que uma versão ampliada desse livro, abrangendo o período 1919-1939 foi publicada em 1951.

As matrizes de relações interindustriais de Leontief correspondem, na realidade, a uma simplificação do modelo walrasiano. Leontief simplificou os modelos de equações simultâneas desenvolvidas no final do século XIX, de tal modo que pudessem ser estimadas empiricamente as inter-relações observadas dentro do aparelho de produção das economias nacionais. Expressando essas inter-relações em sua forma linear mais simples, a matriz de Leontief pode ser considerada como uma desagregação, 
das contas básicas de um sistema tradicional de contabilidade social; como explica Dorfman (1954).

A matriz dá ênfase às transações intra e interindustriais, revelando as conexões estabelecidas para o processamento da produção e, para isto, apóia-se nos seguintes elementos:

1. desagregação do total da demanda final, segundo as categorias de transações que a compõem, para cada um dos ramos (setores) de atividade produtiva considerados;

2. desagregação do valor agregado pelos diversos setores considerados quando do processamento da produção;

3. desagregação da demanda intermediária, representada pelos fornecimentos e aquisições de cada setor em relação a si próprio e aos demais (núcleo principal e de maior interesse da matriz).

A partir das estimativas da demanda intermediária, em nível de transações interindustriais, pode-se então definir a matriz de coeficientes técnicos, que indica em termos relativos a procedência dos insumos necessários a cada setor, para que ele realize sua produção. Complementarmente, pode-se ainda definir a matriz dos requisitos diretos $e$ indiretos por unidade de demanda final, que mostra as repercussões, em todo o aparelho de produção da economia, decorrentes de uma alteração quantitativa em qualquer um dos componentes da demanda final. É intuitivo que, em decorrência de uma modificação (aumento ou redução) na demanda final do produto de determinado setor, haverá repercussões (ou impactos) em todo o aparelho de produção da economia (Miller\&Blair, 1985).

O setor afetado alterará a quantidade adquirida de insumos, afetando os setores que lhe fornecem, nas proporções definidas pela matriz dos coeficientes técnicos. A partir daí, o setores afetados também irão alterar as quantidades de suas compras, propagando-se, assim, em todo o sistema a alteração inicial observada. 
Para concluir esta breve introdução, pode-se recorrer ao próprio Leontief:

"A análise de insumo-produto é uma extensão prática da teoria clássica de interdependência geral, que vê a economia inteira de uma região, de um país ou inclusive do mundo como um só sistema e se propõe interpretar todas as suas funções em termos das propriedades específicas mensuráveis de sua estrutura" (Leontief ,1983).

Para melhor compreensão das relações intersetoriais, pode-se observar o quadro de insumo-produto simplificado (quadro 4.1).

Quadro 4.1: Matriz de insumo-produto do tipo Leontief para três setores.

\begin{tabular}{|c|c|c|c|c|c|c|c|c|c|c|c|}
\hline \multirow{3}{*}{\multicolumn{2}{|c|}{ Setores }} & \multicolumn{9}{|c|}{ Compras $(j)$} & \multirow{3}{*}{$\begin{array}{l}\text { Valor } \\
\text { bruto } \\
\text { da } \\
\text { produ- } \\
\text { ção } \\
\end{array}$} \\
\hline & & \multicolumn{4}{|c|}{ Demanda intermediária } & \multicolumn{5}{|c|}{ Demanda final } & \\
\hline & & $\begin{array}{c}\text { Setor } \\
1 \\
\end{array}$ & $\begin{array}{c}\text { Setor } \\
2 \\
\end{array}$ & $\begin{array}{c}\text { Setor } \\
3 \\
\end{array}$ & $\begin{array}{l}\text { Sub- } \\
\text { total }\end{array}$ & $\mathrm{C}$ & I & G & $\mathbf{E}$ & $\begin{array}{l}\text { Sub- } \\
\text { total }\end{array}$ & \\
\hline \multirow{3}{*}{ 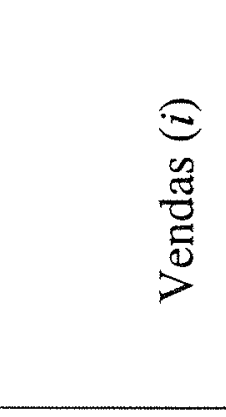 } & $\begin{array}{c}\text { Setor } \\
1\end{array}$ & $Z_{11}$ & $Z_{12}$ & $\mathrm{Z}_{13}$ & $\sum_{j=1}^{3} z_{1 j}$ & $\mathrm{C}_{1}$ & $\mathrm{I}_{1}$ & $\mathrm{G}_{1}$ & $\mathrm{E}_{1}$ & $\mathrm{Y}_{1}$ & $\mathrm{X}_{1}$ \\
\hline & $\begin{array}{c}\text { Setor } \\
2 \\
\end{array}$ & $\mathrm{Z}_{21}$ & $\mathrm{Z}_{22}$ & $\mathrm{Z}_{23}$ & $\sum_{j=1}^{3} z_{2 j}$ & $\mathrm{C}_{2}$ & $\mathrm{I}_{2}$ & $\mathrm{G}_{2}$ & $\mathrm{E}_{2}$ & $\mathrm{Y}_{2}$ & $\mathrm{X}_{2}$ \\
\hline & $\begin{array}{c}\text { Setor } \\
3\end{array}$ & $\mathrm{Z}_{31}$ & $\mathrm{Z}_{32}$ & $\mathrm{Z}_{33}$ & $\sum_{j=1}^{3} z_{3 j}$ & $\mathrm{C}_{3}$ & $\mathrm{I}_{3}$ & $\mathrm{G}_{3}$ & $E_{3}$ & $\mathrm{Y}_{3}$ & $\mathrm{X}_{3}$ \\
\hline \multicolumn{2}{|c|}{ Subtotal } & $\sum_{i=1}^{3} z_{i 1}$ & $\sum_{i=1}^{3} z_{i 2}$ & $\sum_{i=1}^{3} z_{i 3}$ & $\sum_{i, j=1}^{3} z_{i j}$ & $\sum_{i=1}^{3} C_{i}$ & $\sum_{i=1}^{3} I_{i}$ & $\sum_{i=1}^{3} G_{i}$ & $\sum_{i=1}^{3} E_{i}$ & $\sum_{i=1}^{3} Y_{i}$ & $\sum_{i=1}^{3} X_{i}$ \\
\hline \multicolumn{2}{|c|}{ Importações } & $\mathrm{M}_{1}$ & $\mathrm{M}_{2}$ & $\mathrm{M}_{3}$ & $\sum_{j=1}^{3} M_{j}$ & & & & & & \\
\hline \multicolumn{2}{|c|}{ Tributos indiretos líq. } & $\mathrm{T}_{1}$ & $\mathrm{~T}_{2}$ & $\mathrm{~T}_{3}$ & $\sum_{j=1}^{3} T_{j}$ & & & & & & \\
\hline \multicolumn{2}{|c|}{ Valor Adicionado } & $\mathrm{VA}_{1}$ & $\mathrm{VA}_{2}$ & $\mathrm{VA}_{3}$ & $\sum_{j=1}^{3} V A_{j}$ & & & & & & \\
\hline \multicolumn{2}{|c|}{$\begin{array}{l}\text { Valor bruto da } \\
\text { produção }\end{array}$} & $X_{1}$ & $\mathrm{X}_{2}$ & $\mathrm{X}_{3}$ & $\sum_{j=1}^{3} X_{j}$ & & & & & & \\
\hline
\end{tabular}

Fonte: adaptado de Miller \& Blair (1985). 
Considerando o modelo apresentado no quadro 4.1 , são as seguintes as definições fundamentais de suas variáveis e das transações representadas:

\section{Vetores-linha}

$z_{i j} \quad$ fornecimento de insumos do setor $i$ para o setor $j$;

$\mathrm{C}_{\mathrm{i}}$ fornecimento do setor $i$ destinado ao consumo final privado;

$\mathrm{I}_{\mathrm{i}} \quad$ fornecimento do setor $i$ destinado ao investimento privado;

$\mathrm{G}_{\mathrm{i}}$ fornecimento do setor $i$ destinado ao governo (consumo e investimento);

$\mathrm{E}_{\mathrm{i}}$ fornecimento do setor $i$ destinado às exportações para o resto do mundo;

$\mathrm{Y}_{\mathrm{i}}$ total da demanda final atendida pelo setor $i\left(C_{i}+I_{i}+G_{i}+E_{i}\right)$;

$\mathrm{X}_{\mathrm{i}} \quad$ valor bruto da produção do setor $i$ (ou oferta total de $i$ ).

Igualdade básica: $\quad X_{i}=\sum_{j=1}^{3} z_{i j}+Y_{i} \quad(i=1,2,3$,

\section{$\underline{\text { Vetores-coluna }}$}

$\mathrm{M}_{\mathrm{j}} \quad$ importações feitas pelo setor $j$;

$\mathrm{T}_{\mathrm{j}} \quad$ total dos tributos indiretos líquidos recolhidos pelo setor $j$;

$\mathrm{VA}_{j}$ total do valor adicionado bruto do setor $j$ (produto bruto a preços de mercado gerado pelo setor $j$ );

$\mathrm{X}_{\mathbf{j}}$ custo de produção total do setor $j$.

Igualdade básica: $\quad X_{j}=\sum_{i=1}^{3} z_{i j}+M_{j}+T_{j}+V A_{j} \quad(j=1,2,3)$

A partir da equação (1) define-se um sistema de equações lineares simultâneas, cujos parâmetros podem ser estimados empiricamente:

$$
X_{i}=z_{i 1}+z_{i 2}+z_{i 3}+Y_{i} \quad(i=1,2,3)
$$


Deve-se, então, definir o que Leontief chamou de coeficientes técnicos de produção, que são representados, usualmente. por $a_{i j}$ :

$$
a_{i j}=\frac{z_{i j}}{X_{j}}
$$

onde $a_{i j}$ representa quanto o setor $j$ compra do setor $i$, para cada unidade de produção total do setor $j$, sendo $a_{i j}<1 \mathrm{e}\left(1-a_{i j}\right)>0$.

O conjunto de coeficientes $a_{i j}$ constitui a matriz de coeficientes técnicos (matriz A). Cada coluna dessa matriz representa a estrutura tecnológica do setor correspondente. Deve-se salientar que o sistema opera considerando retornos constantes à escala e que os setores utilizam insumos em proporções fixas.

Substituindo a equação (4) na equação (3):

$$
X_{i}=a_{i 1} X_{1}+a_{i 2} X_{2}+a_{i 3} X_{3}+Y_{i} \quad(i=1,2,3)
$$

Tem-se, então, os coeficientes técnicos de produção como parâmetros das equações do sistema.

A equação (5) pode ser escrita em forma matricial:

$$
X=A X+Y
$$

onde:

A é a matriz de coeficientes técnicos diretos, de ordem $(n \times n)$, (ou $3 \times 3$, no exemplo)

$\mathrm{X}$ é o vetor de valor bruto da produção, de ordem $(\mathrm{n} \times 1)$, (ou $3 \times 1$, no exemplo)

Y é o vetor da demanda final total, de ordem $(\mathrm{n} \times 1)$, (ou $3 \times 1$, no exemplo)

Assumindo que a demanda final, $\mathrm{Y}$, é determinada exogenamente, pode-se obter a produção total ,X, necessária para satisfazer essa demanda:

$$
X=(I-A)^{-1} Y
$$


onde $(I-A)^{-I}$ é a matriz de requisitos totais ou matriz de requisitos diretos e indiretos ou, ainda, matriz inversa de Leontief. Sendo que, em $B=(I-A)^{-I}$, cada elemento $b_{i j}$ da matriz inversa de Leontief deve ser interpretado como os requisitos totais da produção do setor $i$, que são necessários para produzir uma unidade de demanda final do setor $j$.

Deve-se notar que as variáveis utilizadas no modelo são originalmente expressas em termos de relações físicas entre insumos e produto, porém, empiricamente, para viabilizar sua utilização, a construção do quadro insumo-produto que serve para estimar as matrizes $A$ e $B$ está baseada em fluxos monetários (Leontief, 1983).

Este fato, das matrizes serem estimadas a partir de fluxos monetários pode afetar os valores dos coeficientes técnicos caso ocorram mudanças nos preços relativos (Nações Unidas, 1966). Para resolver este problema, em termos analíticos, assume-se que os preços são constantes (Miller \& Blair, 1985). 


\subsection{Modelo inter-regional de insumo-produto}

\subsubsection{Considerações gerais}

Geralmente, os estudos de insumo-produto regional buscam quantificar os impactos sobre os setores localizados em uma determinada região que são causados pelas alterações nas demandas finais por produtos da região. Os primeiros estudos regionais que utilizaram modelos de insumo-produto - Isard \& Kuenne (1953); Miller, (1957) - utilizaram uma matriz nacional de coeficientes técnicos em conjugação com um processo de ajustamento, que permitiram estimar características de algumas economias regionais, visto que não existiam coeficientes específicos para as regiões analisadas. Este processo de ajustamento consiste em estimar porcentagens de oferta para cada setor em uma determinada região. (Miller \& Blair, 1985). Desde então, vários autores desenvolveram técnicas para analisar as relações inter-regionais e internacionais partindo da teoria básica de insumo-produto.

Segundo Miller \& Blair (1985), há duas questões básicas de uma economia regional que influenciam as características de um estudo insumo-produto regional. A primeira diz que, apesar das informações de uma matriz insumo-produto nacional serem um tipo de média dos dados de produtores individuais que estão localizados em regiões específicas da nação, a estrutura de produção numa região particular pode ser idêntica ou pode diferir notavelmente daquela apresentada na matriz nacional. A segunda questão diz que, quanto menor uma área econômica, sua economia é mais dependente do comércio com o exterior (para vendas de produtos regionais e compras de insumos necessários para a produção); sendo assim, a importância relativa dos vetores de exportação e de importação sofrerá alterações.

O modelo de Leontief, inicialmente elaborado para estudos das relações internas da economia de uma nação, vem sendo adaptado para investigações de determinada região e para estudos de sua relação com outras. Uma classificação dos 
modelos insumo-produto inter-regionais e sua extensão para modelos de insumo-produto internacionais pode ser encontrada em Montoya (1998, item 4.2); sendo que o mesmo autor desenvolveu uma matriz insumo-produto internacional do Mercosul para o ano de 1990 (idem).

Com relação aos modelos de uma única região desenvolvidos para a economia brasileira, destacam-se as matrizes para a Região Norte e para a região Nordeste, ambas para os anos de 1980 e 1985 e elaboradas, respectivamente, por Silva et al (1994) e Silva et al (1992).

Outra importante experiência na construção de matrizes para grandes regiões no Brasil, refere-se aos trabalhos de Crocomo (1998) e Crocomo \& Guilhoto (1998), que obtiveram a matriz insumo-produto inter-regional do Brasil, via desagregação da matriz nacional de insumo-produto do IBGE para 1985, em 5 regiões, conforme critério do IBGE (Norte, Nordeste, Centro-Oeste, Sudeste, Sul). Entretanto, a composição das regiões utilizada por Crocomo (1998) difere da base de regionalização do IBGE pela inclusão do estado de Mato Grosso na região Norte, ao invés da região Centro-Oeste. A base metodológica adotada por Crocomo segue o modelo inter-regional desenvolvido por Isard (1951), bem como as técnicas de obtenção de coeficientes inter-regionais.

A matriz desenvolvida por Crocomo (1998) servirá como banco de dados básico para a presente pesquisa sobre o agronegócio nas regiões brasileiras e está apresentada, resumidamente, na tabela 4.1 . 


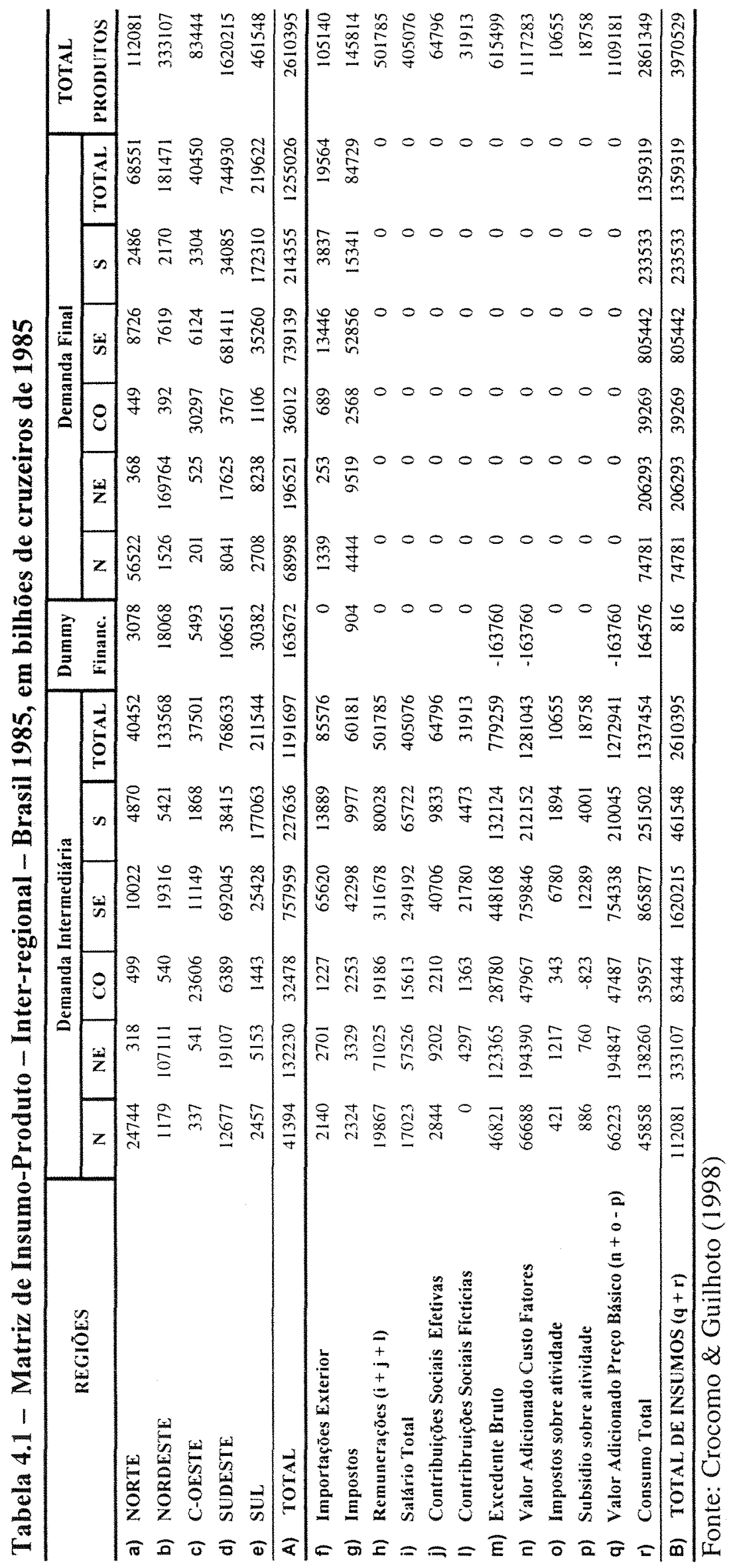




\subsubsection{Enfoque Inter-regional de insumo-produto}

Existem dois tipos principais de modelos de insumo-produto para mais de uma região: modelo inter-regional de insumo-produto (IRIO) e modelo multi-regional de insumo-produto (MRIO). Para os propósitos dessa pesquisa será explicado apenas o funcionamento do modelo inter-regional ou "modelo de Isard", pois sua primeira aplicação ocorreu em Isard (1951).

Segundo o desenvolvimento proposto por Miller \& Blair (1985) e Miller (1998), a formulação do modelo parte de um esquema hipotético do fluxo intersetorial e inter-regional de bens para a região $L$ e para a região $M$, ambas com 2 setores, representado no quadro 4.2 .

Quadro 4.2: Fluxo intersetorial e inter-regional de bens.

\begin{tabular}{|c|c|c|c|c|c|c|}
\hline & & & \multicolumn{4}{|c|}{ Setores compradores } \\
\hline & & & \multicolumn{2}{|c|}{ Região L } & \multicolumn{2}{|c|}{ Região M } \\
\hline & & & 1 & 2 & 1 & 2 \\
\hline \multirow{4}{*}{ 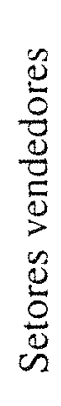 } & $\vec{\rho}$ & 1 & $z_{11}^{L L}$ & $z_{12}^{L L}$ & $z_{11}^{L M}$ & $z_{12}^{L M}$ \\
\hline & 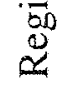 & 2 & $z_{21}^{L L}$ & $z_{22}^{L L}$ & $z_{21}^{L M}$ & $z_{22}^{L M}$ \\
\hline & $\sum_{\substack{0 \\
0}}$ & 1 & $z_{11}^{M L}$ & $z_{12}^{M L}$ & $z_{11}^{M M}$ & $z_{12}^{M M}$ \\
\hline & $\begin{array}{l}\overrightarrow{D D} \\
\stackrel{\otimes}{\simeq}\end{array}$ & 2 & $z_{21}^{M L}$ & $z_{22}^{M L}$ & $z_{21}^{M M}$ & $z_{22}^{M M}$ \\
\hline
\end{tabular}

Fonte: Miller \& Blair (1985), adaptado pelo autor. 
Pode-se apresentar o modelo, a partir do exemplo hipotético dos fluxos, intersetoriais e inter-regionais de bens para as regiões $\mathrm{L}$ e $\mathrm{M}$, com 2 setores, como se segue:

$z_{i j}^{L L}$ - fluxo monetário do setor $i$ para o setor $j$ na região L;

$z_{i j}^{M M}$ - fluxo monetário do setor $i$ para o setor $j$ na região $\mathrm{M}$;

$z_{i j}^{L M}$ - fluxo monetário do setor $i$ da região $\mathrm{L}$, para o setor $j$ da região $\mathrm{M}$;

$z_{i j}^{M L}$ - fluxo monetário do setor $i$ da região $\mathrm{M}$, para o setor $j$ da região $\mathrm{L}$

A matriz completa pode ser representada por:

$$
\mathrm{Z}=\left[\begin{array}{ll}
Z^{L L} & Z^{L M} \\
Z^{M L} & Z^{M M}
\end{array}\right]
$$

onde:

$Z^{L L}$ e $Z^{M M}$, representam matrizes dos fluxo monetários intraregionais, e

$Z^{L M}$ e $Z^{M L}$, representam matrizes dos fluxo monetários inter-regionais.

Apesar de todas as matrizes apresentadas neste exemplo hipotético apresentarem dimensões $2 \times 2$, Miller \& Blair (1985) explicam que as matrizes $Z^{L M} \mathrm{e}$ $Z^{M L}$ ("fora da diagonal") não necessitam ser quadradas, enquanto as matrizes $Z^{L L}$ e $Z^{M M}$ ("na diagonal") são sempre quadradas.

Considerando a equação básica do modelo geral de insumo-produto ou equação de Leontief, (1983):

$$
X_{i}=z_{i 1}+z_{i 2}+\ldots+z_{i i}+\ldots+z_{i n}+Y_{i}
$$

onde, $X_{i}$ indica o total da produção do setor $i, z_{\text {in }}$ o fluxo monetário do setor $i$ para o setor $\mathrm{n}$, e $Y_{i}$ é demanda final do setor $i$. 
Considerando a produção do setor 1 na região $\mathrm{L}\left(X_{I}^{L}\right)$, chega-se à seguinte equação:

$$
X_{1}^{L}=z_{11}^{L L}+z_{12}^{L L}+z_{11}^{L M}+z_{12}^{L M}+Y_{1}^{L}
$$

Os dois primeiros termos do lado direito representam as vendas do setor 1 dentro da região $L$, os próximos 2 termos são os fluxos de comércio interregional do setor 1 na região $L$ para os dois setores que estão na região $M$. O último termo, $Y_{1}^{L}$, representa as vendas para a demanda final na região L. Pode-se construir equações similares para $X_{2}^{L}, X_{1}^{M}$ e $X_{2}^{M}$.

Considerando os coeficientes de insumo regional para $\mathrm{L}$ e $\mathrm{M}$, tem-se:

\section{Os coeficientes intra-regionais:}

$$
a_{i j}^{L L}=\frac{z_{i j}^{L L}}{X_{j}^{L}} \Rightarrow z_{i j}^{L L}=a_{i j}^{L L} X_{j}^{L}
$$

onde define-se:

$a_{i j}^{L L}$, como coeficientes técnicos de produção, e que representam quanto o setor $j$ da região $L$ compra do setor $i$ da região $L$, por unidade produzida do setor $j$.

$$
a_{i j}^{M M}=\frac{z_{i j}^{M M}}{X_{j}^{M}} \Rightarrow z_{i j}^{M M}=a_{i j}^{M M} X_{j}^{M}
$$

onde define-se:

$a_{i j}^{h M}$, como coeficientes técnicos de produção, que representam quanto o setor $j$ da região $\mathrm{M}$, compra do setor $i$, da região $\mathrm{M}$, por unidade produzida do setor $j$. 


\section{Os coeficientes inter-regionais:}

$$
a_{i j}^{M L}=\frac{z_{i j}^{M L}}{X_{j}^{L}} \Rightarrow z_{i j}^{M L}=a_{i j}^{M L} X_{j}^{L}
$$

onde define-se:

$a_{i j}^{M L}$, como coeficientes técnicos de produção, que representam quanto, o setor $j$ da região $M$ compra do setor $i$ da região $L$, por unidade produzida do setor $j$.

$$
a_{i j}^{L M}=\frac{z_{i j}^{L M}}{X_{j}^{M}} \Rightarrow z_{i j}^{L M}=a_{i j}^{L M} X_{j}^{M}
$$

onde define-se:

$a_{i j}^{L M}$, como coeficientes técnicos de produção, que representam quanto o setor $j$ da região $L$ compra do setor $i$ da região $M$, por unidade produzida do setor $j$.

Estes coeficientes podem ser substituídos em (8), obtendo:

$$
X_{1}^{L}=a_{11}^{L L} X_{1}^{L}+a_{12}^{L L} X_{2}^{L}+a_{11}^{L M} X_{1}^{M}+a_{12}^{L M} X_{2}^{M}+Y_{1}^{L}
$$

As produções para os demais setores são obtidas de forma similar.

Isolando, $Y_{1}$ e colocando em evidência, $X_{1}$, tem-se:

$$
\left(1-a_{11}^{L L}\right) X_{1}^{L}-a_{12}^{L L} X_{2}^{L}-a_{11}^{L M} X_{1}^{M}-a_{12}^{L M} X_{2}^{M}=Y_{1}^{L}
$$

As demais demandas finais podem ser obtidas similarmente.

Portanto, de acordo com (em forma matricial):

$$
A^{L L}=Z^{L L}\left(\hat{X}^{L}\right)^{-1} \text {, constroi-se a matriz } A^{L L} \text {, para os } 2 \text { setores: }
$$

Onde, $A^{L L}$, representa a matriz de coeficientes técnicos, intraregionais, de produção.

Da mesma forma para : $\mathrm{A}^{\mathrm{LM}}, \mathrm{A}^{\mathrm{MM}}, \mathrm{A}^{\mathrm{ML}}$. 
Definem-se, agora, as seguintes matrizes:

$$
A=\left[\begin{array}{ccc}
A^{L L} & \vdots & A^{L M} \\
\cdots & \cdots & \cdots \\
A^{M L} & \vdots & A^{M M}
\end{array}\right] \quad X=\left[\begin{array}{c}
X^{L} \\
\cdots \\
X^{M}
\end{array}\right] \quad Y=\left[\begin{array}{c}
Y^{L} \\
\cdots \\
Y^{M}
\end{array}\right]
$$

O sistema inter-regional completo de insumo produto é representado por:

$$
(I-A) X=Y, \quad \text { ou } \quad X=(I-A)^{-1} Y
$$

e as matrizes podem ser dispostas da seguinte forma:

$$
\left\{\left[\begin{array}{ccc}
I & \vdots & 0 \\
\cdots & \cdots & \cdots \\
0 & \vdots & I
\end{array}\right]-\left[\begin{array}{ccc}
A^{L L} & \vdots & A^{L M} \\
\dddot{M} L & \because & \dddot{M} M \\
A^{M L} & \vdots & A^{M M}
\end{array}\right]\right\}\left[\begin{array}{c}
X^{L} \\
\cdots \\
X^{M}
\end{array}\right]=\left[\begin{array}{c}
Y^{L} \\
\cdots \\
Y^{M}
\end{array}\right]
$$

Efetuando estas operações, obtem-se os modelos básicos, necessários à análise inter-regional proposta por Isard, isto é:

$$
\begin{aligned}
& \left(I-A^{L L}\right) X^{L}-A^{L M} X^{M}=Y^{L} \\
& -A^{M L} X^{L}+\left(I-A^{M M}\right) X^{M}=Y^{M}
\end{aligned}
$$

\subsubsection{Obtenção de coeficientes regionais}

\section{a) Quociente locacional}

Segundo Miller \& Blair (1985), o quociente locacional simples para o setor i na região $\mathrm{R}$ é definido por:

$$
L Q_{i}{ }^{R}=\left[\frac{X_{i}^{R} / X^{R}}{X_{i}^{N} / X^{N}}\right]
$$


onde:

$X_{i}^{R} \quad$ representa o produto total do setor $i$ na região $R$;

$X_{i}^{N} \quad$ representa o produto total do setor $i$ na nação $N$;

$X^{R} \quad$ representa a produção total da região $R$;

$X^{N} \quad$ representa a produção total da nação $N$.

Esse quociente é interpretado da seguinte maneira: o numerador representa a participação do setor $i$ (da região $R$ ) na produção total da região $R$; o denominador demonstra a parcela do setor $i$ (da nação $N$ ) no produto total nacional. Ou seja, a razão $L Q_{i}{ }^{R}$ é uma comparação entre a importância do setor $i$ para uma dada região e a importância desse mesmo setor para o total da nação.

Nesse sentido, segundo Miller \& Blair (1985), se $L Q_{i}^{R} \geq 1$ diz-se que o setor $i$ é mais localizado, ou concentrado, na região $R$ do que na nação como um todo, portanto este setor, nesta região, pode estar orientado para exportação. Por outro lado, quando $L Q_{i}^{R}<1$, o setor $i$ é menos concentrado na região $R$ do que nacionalmente, sendo, portanto, nesta região, um importador em potencial.

\section{b) Método RAS}

A técnica denominada método RAS permite, no caso de um problema de regionalização, gerar uma matriz de coefícientes para uma região em particular, $A(R)$, conhecidas informações sobre algumas atividades econômicas regionais como, a produção total dos setores da região, $X(R)$; as vendas interindustriais totais, $U(R)$; e as compras interindustriais totais, $\mathrm{V}(\mathrm{R})$. Tendo como ponto de partida a matriz insumoproduto nacional, $A(N)$. Considerando o fato de que $A(N)$ reflete uma média das relações insumo-produto de todas as regiōes da nação. 
O método RAS surgiu como uma técnica utilizada para a atualização da matriz insumo-produto, elaborada por Richard Stone em $1963^{7}$ (Teixeira \& Silva, 1978 e Silveira, 1993). Esse método é também conhecido como método biproporcional; esta terminologia foi introduzida por Bacharach (1970) e não representa uma tentativa de substituir seu nome mas, apenas, ajudar a abstrair as características matemáticas da interpretação econômica (Teixeira \& Silva, 1978).

Percebe-se então, que o método RAS permite estimar matrizes de insumoproduto tanto em sua dimensão temporal quanto na dimensão espacial. Será exposta, a seguir, a versão tradicional do método RAS para projetar estrutura tecnológica (atualizar matrizes) apresentada em Miller \& Blair (1985).

O problema básico consiste em, partindo de uma matriz insumo-produto conhecida para um dado ano no passado, chamada de $\mathrm{A}(0)$; obter, através de sua atualização, a estimativa dos coeficientes de insumo-produto para um ano recente ou ano 1, chamada de $\tilde{A}(1)$.

Portanto, são conhecidos os coeficientes técnicos $a_{i j}=\frac{z_{i j}}{X_{j}}$ para o ano zero e pretende-se obter as estimativas desses mesmos coeficientes para o ano 1.

$$
A(0)=\left[\begin{array}{ccc}
a_{11}(0) & \cdots & a_{1 n}(0) \\
\vdots & \ddots & \vdots \\
a_{n 1}(0) & \cdots & a_{n n}(0)
\end{array}\right]
$$

Para atingir essa meta, o modelo necessita de 3 vetores de informações referentes ao ano 1:

$X_{j} \quad$ - a produção total de cada setor $j ;$

\footnotetext{
${ }^{7}$ Stone, R., ed. Input-output relationships, 1954-1966. London: Chapman and Hall, 1963 (A programme for growth).
} 
$\sum_{j=1}^{n} z_{i j}$ - as vendas interindustriais totais realizadas pelo setor $i$. Refere-se à soma das colunas da matriz $\mathrm{Z}$ e é representada por $U_{i}$ na literatura RAS;

$\sum_{i=1}^{n} z_{i j}$ - as compras interindustriais totais realizadas pelo setor $j$. Refere-se à soma das linhas da matriz Z e é representada por $V_{i}$ na literatura RAS;

Sendo que $z_{i j}$ refere-se às vendas do setor $i$ para cada setor $j$ (ou, alternativamente, às compras do setor $j$ de cada setor $i$ ).

Definem-se, então, três vetores referentes ao ano 1; os quais, juntamente com a matriz $\mathrm{A}(0)$ serão utilizado para estimar $\tilde{A}(1)$ :

$$
X(1)=\left[\begin{array}{c}
X_{1}(1) \\
\vdots \\
X_{n}(1)
\end{array}\right] ; \quad U(1)=\left[\begin{array}{c}
U_{1}(1) \\
\vdots \\
U_{n}(1)
\end{array}\right] \quad \text { e } \quad V(1)=\left[\begin{array}{llll}
V_{1}(1) & \cdots & V_{n}(1)
\end{array}\right]
$$

Inicialmente, supõe-se que os coeficientes técnicos permanecem estáveis no tempo, ou seja, $\mathrm{A}(0)=\widetilde{A}(1)$. Para testar esta hipótese, deve-se investigar se as informações obtidas para o ano 1 são consistentes. Uma vez que os vetores de compras e vendas referem-se a somas das linhas e das colunas da matriz de transações, será necessário converter os coeficientes $a_{i j}$, em transações, $z_{i j}$, através da relação $z_{i j}=a_{i j} X_{j}$.

Em termos matriciais, desde que $A=Z(\hat{X})^{-1}$, tem-se que $Z=A(\hat{X})$. Porém a hipótese $\mathrm{A}(0)=\tilde{A}(1)$ implica que $Z=A(0) \hat{X}(1)$.

Deve-se, então, verificar se o somatório de linhas e colunas de $Z$ são consistentes com $U(1)$ e $V(1)$, respectivamente.

Pós-multiplicando $Z$ pelo vetor $i$, definido como um vetor coluna de valores unitários, obtem-se o total estimado das linhas de $Z$, denominado de $U^{l}$ (estimativa das vendas, por setor) ou seja:

$$
\lfloor A(0) \hat{X}(1)\rfloor i=U^{1}
$$


Pré-multiplicando $Z$ pelo vetor $i^{\prime}$ (uma linha de valores unitários), obtém-se o total estimado das colunas de $Z$, denominado de $V^{l}$, ou seja:

$$
\left.i^{\prime} \mid A(0) \hat{X}(1)\right\rfloor=V^{1}
$$

Se $U^{I}=U(1)$ e $V^{l}=V(1)$, as estimativas para os elementos de $\tilde{A}(1)$ estão de acordo com a hipótese inicial e o trabalho encerra-se com o cálculo:

$$
\tilde{A}(1)=Z(1)[\hat{X}(1)]^{-1}
$$

Entretanto, segundo Miller \& Blair (1985), o mais provável é que a hipótese de não haver mudança falhe, ocorrendo o seguinte:

$$
U^{I} \neq U(1) \quad \quad \quad V^{I} \neq V(1)
$$

Sendo assim, os elementos de $Z$ deverão ser corrigidos pelas seguintes proporções:

$$
r_{i}^{1}=\frac{U_{i}(1)}{U_{i}^{1}} \quad \text { e } \quad s_{i}^{1}=\frac{V_{i}(1)}{V_{i}^{1}}
$$

Em forma de matrizes:

$$
R^{1}=\left[\begin{array}{ccc}
r_{1}^{1} & \cdots & 0 \\
\vdots & \ddots & \vdots \\
0 & \cdots & r_{n}^{1}
\end{array}\right] \quad \text { e } \quad S^{1}=\left[\begin{array}{ccc}
s_{1}^{1} & \cdots & 0 \\
\vdots & \ddots & \vdots \\
0 & \cdots & s_{n}^{1}
\end{array}\right]
$$

A correção ocorre simultaneamente, de acordo com:

$$
\widetilde{A}(1)=R^{1} A(0) S^{\mathrm{l}}
$$

O lado direito da equação indica o nome do método "RAS".

Esse processo deve ser repetido até convergir para uma estimativa que esteja dentro de um desvio mínimo aceitável.

Aplicações do método RAS para matrizes insumo-produto do Brasil podem ser consultadas em Crócomo (1998) e Bêrni (1998). 


\subsection{Obtenção dos dados e apresentação das matrizes}

Os dados básicos para esta pesquisa foram obtidos da matriz inter-regional para o Brasil desenvolvida por Crócomo \& Guilhoto (1998), para o ano de 1985 (foram realizados alguns ajustes nessa matriz). Para a construção das matrizes inter-regionais referentes aos anos de 1990 e 1995 foram necessários, também, utilizar as matrizes de insumo-produto do Brasil para os anos de 1985, 1990 e 1995, publicadas pelo IBGE (Instituto Brasileiro de Geografia e Estatísitca), respectivamente IBGE (1995), IBGE (1996) e IBGE (1997).

A obtenção das informaçães referentes ao valor total da atividade dos setores industriais das regiões do Brasil foi baseada na metodologia de Haguenauer et al (1998). O método para desagregação do valor da produção industrial parte do Censo Industrial de 1985 (IBGE, 1991); desagrega as informações segundo a classificação das matrizes de insumo-produto; utiliza os dados (índices de quantum) da Pesquisa Industrial MensalProdução Física (PIM-PF) dos anos de 1990 e 1995 e, finalmente, utiliza os índices mensais de preços atacadistas (IPA-OG) para atualização nominal dos valores.

As tabelas 4.2, 4.3 e 4.4 apresentam, de forma resumida, as matrizes de insumoproduto inter-regionais obtidas para o Brasil, respectivamente, para os anos de 1985, 1990 e 1995. Essas matrizes serão utilizadas para os cálculos referentes ao agronegócio das regiões brasileiras. As versões completas dessas matrizes são apresentadas nos anexos ao final da Tese. 


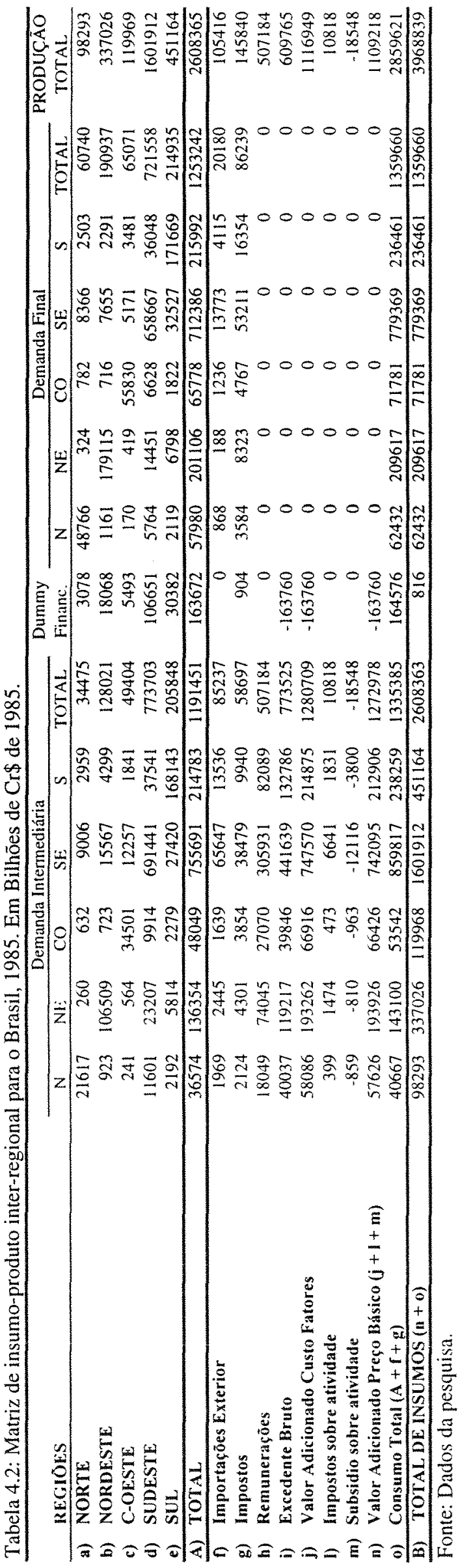



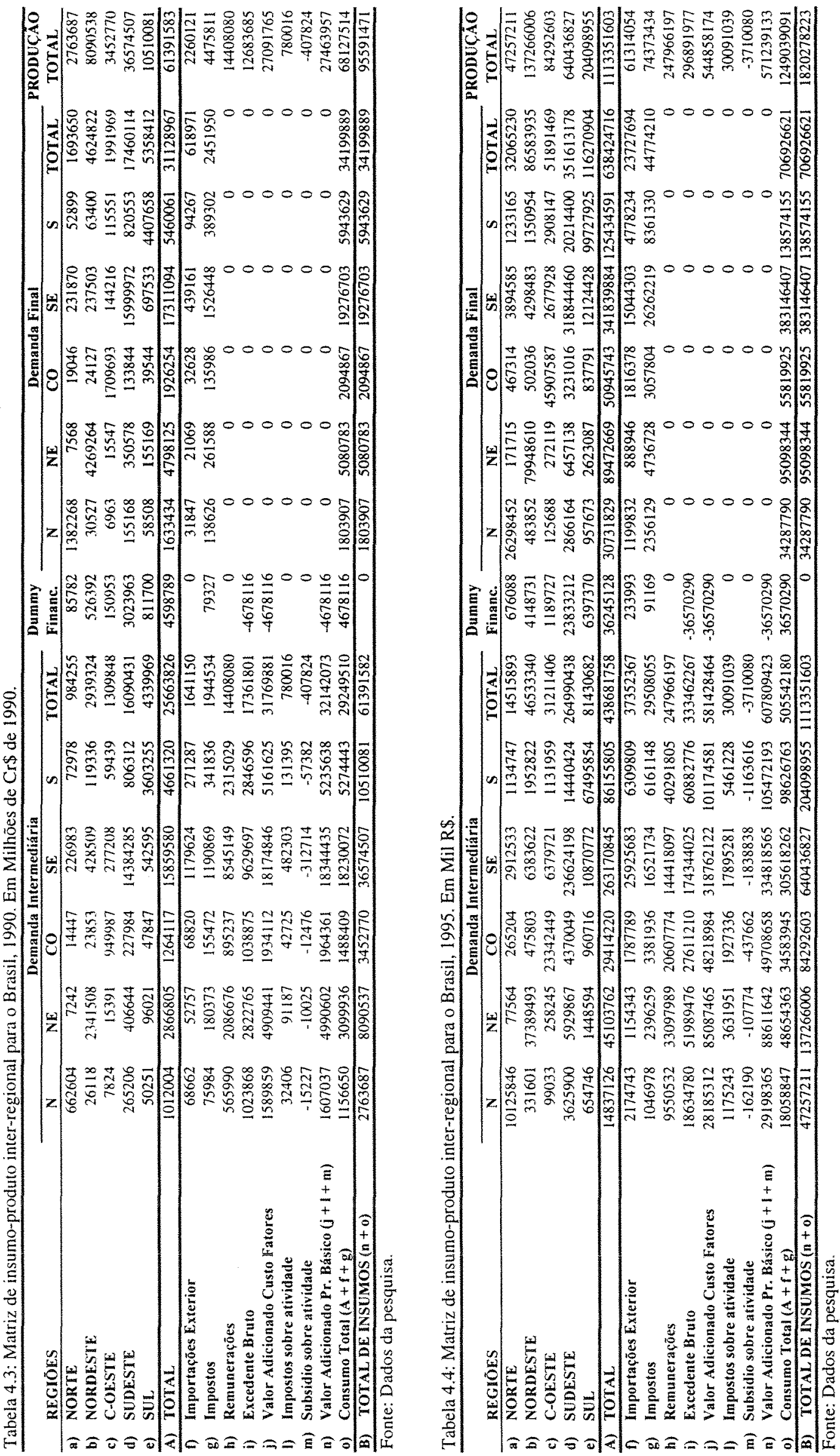


\subsection{Dimensionamento do agronegócio para as regiões brasileiras}

Diversos autores preocuparam-se em "medir" a importância do complexo agroindustrial ou agronegócio na economia brasileira, entre os trabalhos que se destacaram nesta tarefa pode-se citar Araújo et al. (1990); Lauscher (1995); Furtuoso (1998) e Montoya \& Guilhoto (1999).

Basicamente, os autores dessas pesquisas mensuraram o agronegócio partindo de uma visão sistêmica, utilizando-se de matrizes insumo-produto nacionais, para considerar os fluxos e transferências de insumos e de produtos entre os setores. Outro ponto em comum entre as pesquisas foi a utilização dos trabalhos de Davis \& Goldberg (1957) e Malassis (1969) como referencial teórico para a metodologia de mensuração do agronegócio.

A metodologia de mensuração do agronegócio proposta na presente tese toma como referencial metodológico básico os trabalhos de Lauscher (1995); Furtuoso (1998) e Montoya \& Guilhoto (1999). Entretanto, pelo fato desses autores analisar o agronegócio brasileiro de forma agregada e a proposta da tese é a de mensurar o agronegócio das regiões brasileiras, bem como as relações de dependência que existem entre estas regiões, deve-se desenvolver uma metodologia de mensuração que considere esses objetivos.

O quadro 4.3 apresenta a matriz insumo-produto inter-regional simplificada para a região Sudeste do Brasil, sendo que as relações intra-regionais da demanda intermediária da região Sudeste apresentam-se desagregadas em 17 setores produtivos, os quais estão especificados no quadro. Esta forma de apresentação da matriz interregional - destacando o setor agroindústria - permite que se dimensione o agronegócio para a região - Sudeste, no caso - bem como as inter-relações com as outras regiões. 


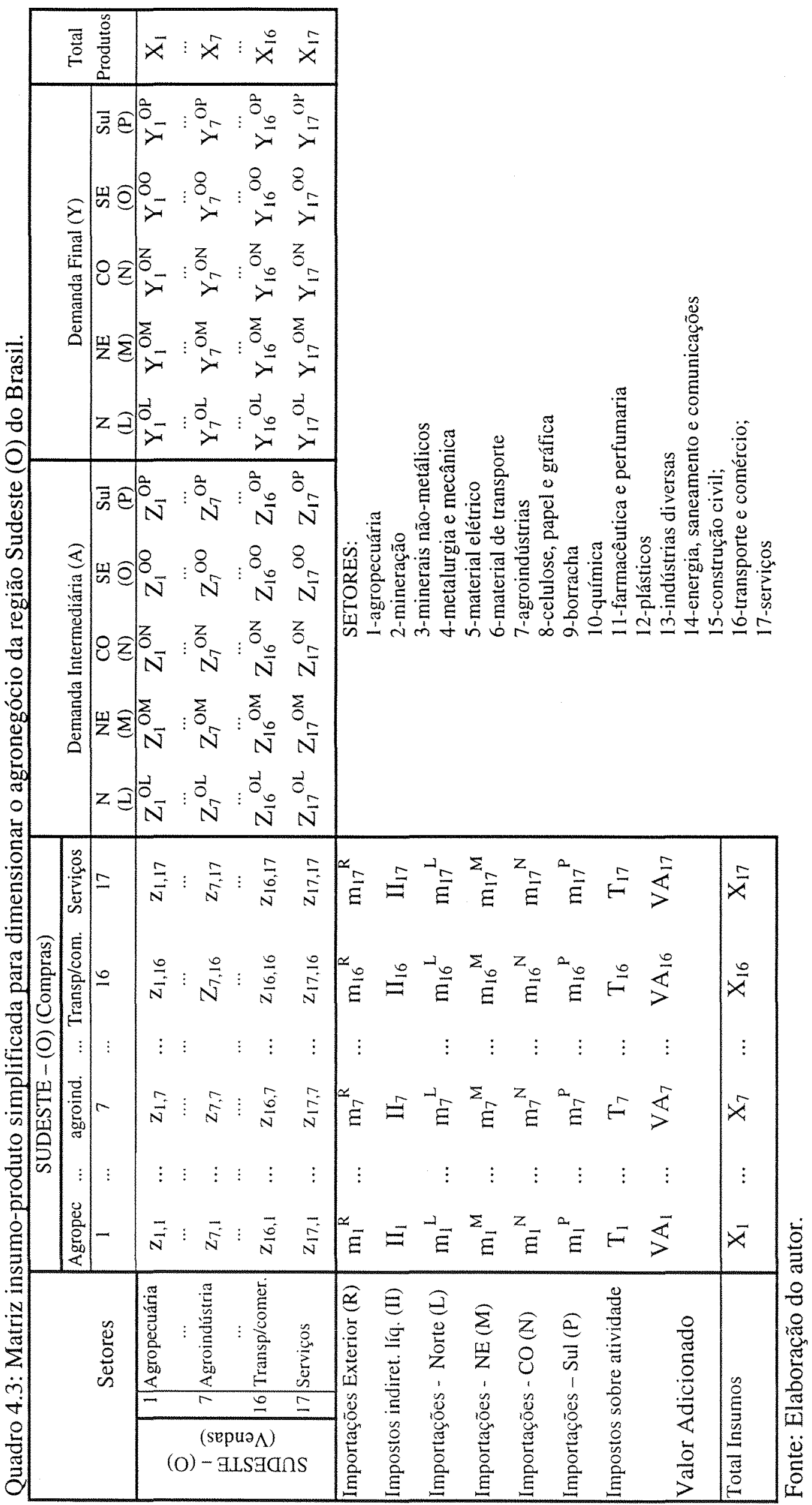


A maioria das variáveis e relações apresentadas no Quadro 4.3, foram, de certa forma, explicadas nos itens anteriores deste capítulo sobre a metodologia da pesquisa. Sendo assim, os comentários apresentados neste tópico apenas abordarão questões que ainda não foram discutidas.

As colunas do Quadro 4.3 representam os setores da demanda, divididos em demanda intermediária (A) e demanda final (F). No caso, a demanda intermediária da região Sudeste $(\mathrm{O})$ é apresentada desagregada em 17 setores, enquanto a demanda intermediária das outras regiões que compram dos setores da região Sudeste é apresentada de forma agregada. Por exemplo, $z_{1,7}$ representa quanto o setor da agroindústria compra do setor agropecuário, sendo que ambos os setores são pertencentes à região Sudeste; e $Z_{l}^{O L}$ mostra quanto os setores em conjunto da região Norte (L) compram do setor agropecuário da região Sudeste $(\mathrm{O})$, esses fluxos interregionais podem ser considerados exportações para demanda intermediária ou exportações DI ${ }^{8}$

Vale lembrar que as compras realizadas na demanda intermediária servem como insumos no processo produtivo das regiões, ou seja, representam o consumo intermediário das regiões.

As colunas da demanda final (Y) no quadro 4.3 referem-se às compras das regiões feitas aos setores da região Sudeste que serão destinadas ao consumo final. Estas transações podem ser consideradas exportações para demanda final ou exportações DF.

Os setores da demanda final são subdivididos em consumo das famílias (C), consumo do governo $(\mathrm{G})$, investimento $(\mathrm{I})$ e exportações $(\mathrm{X})$; entretanto, no quadro 3 , eles estão apresentados de maneira agregada.

Um aspecto importante da construção da matriz inter-regional do Brasil deve ser destacado: as exportações $(\mathrm{X})$ representam as vendas para o exterior $(\mathrm{R})$ ou resto do mundo; e, como a matriz trata da região Sudeste $(O)$ esses valores estão representados

\footnotetext{
${ }^{8}$ Note que $\mathrm{Z}_{\mathrm{i}}{ }^{00}$ representa a soma das compras de todos os setores da região Sudeste em relação ao setor agropecuário da própria região.
} 
apenas na coluna da demanda final SE $(\mathrm{O})$, para as outras regiões o valor das exportações é zero. Por exemplo, $Y_{l}^{O L}$ mostra quanto a região Norte (L) compra do setor agropecuário da região Sudeste, sendo que essas compras são destinadas a C, G ou I; e $Y_{I}^{O O}$ representa as compras ao setor agropecuário dentro da região Sudeste destinadas a C, G, I ou X.

Com relação às compras dos setores da região Sudeste feitas aos setores das outras regiões a matriz destaca apenas as compras de suprimentos, pois as compras para consumo final estarão representadas na demanda final das matrizes das outras regiões em estudo. Por exemplo, na matriz da região Norte haverá uma coluna de demanda final para a região sudeste, indicando as compras feitas por esta região de produtos originários da região Norte, para consumo final

Nesse sentido, por exemplo, $\mathrm{z}_{7,1}$ representa quanto o setor agropecuário compra do setor agroindústria, ambos da região Sudeste; $\mathrm{m}_{1}{ }^{\mathrm{R}}$ indica quanto o setor agropecuário da região Sudeste compra (importa) do exterior ou resto do mundo; $\mathrm{m}_{1}{ }^{\mathrm{L}}$ mostra quanto o setor agropecuário da região Sudeste compra (importa) do conjunto de setores da região Norte (L).

Com base nas informações, pode-se desenvolver o método para o cálculo do agronegócio nas regiões Sudeste do Brasil. Inicialmente, deve-se considerar que a estrutura do agronegócio está dividida em três partes:

a) uma parte que precede a produção rural, que engloba o conjunto de setores fornecedores de insumos e fatores de produção para as propriedades rurais, denominado de agregado I ou montante do agronegócio, ou ainda, indústria para a agricultura;

b) o setor de produção rural ou, apenas, setor agropecuário, denominado de agregado II;

c) os setores que recebem a produção agropecuária para agregar valor através do armazenamento, processamento e distribuição para o consumidor final, chamado de agregado III ou jusante do agronegócio. 


\subsubsection{Dimensionamento do agregado I}

Para dimensionar o agregado I ou montante do agronegócio utiliza-se informações referentes ao valor total dos insumos adquiridos pelo agregado II (agropecuária), ou seja, o valor do montante é estimado indiretamente baseado na estrutura da demanda intermediária da agropecuária, considerando as compras feitas na região em análise, nas demais regiões do país e no exterior. Esta sistemática é utilizada devido a indisponibilidade de estatísticas que apontem a parcela do valor adicionado das indústrias ofertantes de insumos absorvida pelo setor rural. A hipótese implícita neste método de cálculo é de que os setores industriais, exceto os setores agroindustriais, fornecedores de insumos e bens de capital para o setor rural apresentam um consumo intermediário de produtos agrícolas praticamente nulo. Esta hipótese foi confirmada para o Brasil por Furtuoso (1998, p.68).

Sendo assim, o valor do agregado I para a região Sudeste é calculado da seguinte maneira:

$$
\text { Agregado } \mathrm{I}=z_{11}+z_{21}+\cdots+z_{17,1}+m_{1}^{R}+m_{1}^{L}+m_{1}^{M}+m_{1}^{N}+m_{1}^{p}
$$

onde:

$z_{11}$ a $z_{17,1}$ representam os insumos consumidos pelo setor agropecuário originados na região Sudeste;

$m_{l}{ }^{k}$ com $k=R, L, M, N, P$ representam as importações de insumos feitas pelo setor agropecuário do exterior $(R)$ e às demais regiões do país $(L, M, N, P)$.

Deve-se salientar que, para os propósitos desta pesquisa, o conhecimento dessas importações é importante não só para o dimensionamento do agregado I, mas também pelo fato delas indicarem possíveis dependências da região com relação aos insumos necessários para o setor de produção rural. 


\subsubsection{Dimensionamento do agregado II}

Para o dimensionamento do agregado II (agropecuária) considera-se a renda ou o valor adicionado gerado pelo setor agropecuário e extrativo vegetal:

$$
\text { Agregado } \mathrm{II}=V A_{1}-T_{1}
$$

onde

$V A_{1}$ representa o valor adicionado a preços de mercado gerado pelo setor agropecuário;

$T_{l}$ representa o valor dos impostos líquidos sobre atividade (impostos sobre atividade menos subsídios sobre atividade)

Esta forma de cálculo permite que se obtenha o valor adicionado do setor de produção rural ao custo de fatores.

Pelo fato da matriz utilizada apresentar as relações inter-regionais, pode-se analisar a interdependência da região Sudeste em relação às outras regiões do país. Para isso, calcula-se as exportações da demanda intermediária $(D I)$ e as exportações da demanda final $(D F)$ realizadas pelo setor agropecuário da região Sudeste para as outras regiões do Brasil.

Essas exportações podem ser obtidas da seguinte maneira:

$$
\begin{array}{ll}
\text { Exportações } D I=\frac{V A_{1}}{X_{1}} Z_{1}^{O K} & (K=L, M, N, P) \\
\text { Exportações } D F=\frac{V A_{1}}{X_{1}} Y_{1}^{O K} & (K=L, M, N, P)
\end{array}
$$

onde

$V A_{1} / X_{1}$ é a participação do valor adicionado do setor agropecuário no valor bruto da produção do mesmo setor na região Sudeste.

$Z_{i}^{O K}$ representa os valores da demanda intermediária $(D I)$ para o setor agropecuário da região Sudeste nas demais regiões do país. 
$Y_{I}^{O K}$ representa os valores da demanda final $(D F)$ para o setor agropecuário da região Sudeste nas demais regiões do país.

\subsubsection{Dimensionamento do agregado III}

Aderindo à metodologia utilizada por Lauschner (1995) e Montoya \& Guilhoto (1999), o agregado III ou jusante do agronegócio é dividido em duas partes, produção agroindustrial $(P A D)$ e distribuição final $(D I F)$, sendo necessário, portanto, duas etapas no processo de cálculo ${ }^{9}$.

Inicialmente, deve-se calcular o valor da produção agroindustrial, tomando-se o valor adicionado gerado pelas indústrias de base agrícola que compõem o setor agroindustrial da região Sudeste.

Pelo fato dessa pesquisa analisar diversas regiões do Brasil simultaneamente, deve-se utilizar um conceito uniforme de agroindústria, o qual possa ser aplicado nas matrizes insumo-produto das diferentes regiões brasileiras.

Em virtude disso, será adotado, nessa pesquisa, os critérios da Classificação Industrial Internacional Uniforme (CIIU - versão2) de todas as atividades econômicas. Segundo essa classificação o setor agroindustrial de base agrícola é definido pelos produtos dos seguintes setores:

$\begin{array}{ll}\mathrm{n}^{\underline{0}} & \text { Setor } \\ 14 & \text { madeira e mobiliário } \\ 22 & \text { indústria têxtil } \\ 23 & \text { artigos de vestuário } \\ 24 & \text { produtos de couro e calçados } \\ 25 & \text { produtos do café }\end{array}$

\footnotetext{
${ }^{9}$ Furtuoso (1998) interpreta de forma diferente a composição do agronegócio e prefere dividi-lo em 4 agregados - agregado III (indústria de base agrícola) e agregado IV (distribuição final) - entretanto, a autora admite que ambos os agregados compõem o setor a jusante do agronegócio.
} 
beneficiamento de produtos vegetais

27

abate de animais

28

indústria de laticínios

29

fabricação de açúcar

30

fabricação de óleos vegetais, tortas e farelos

31

fabricação de produtos alimentares e bebidas

Nota-se que essa classificação não engloba o setor de química, utilizado por Furtuoso (1998) em suas três versões de agroindústria. A justificativa é a seguinte: Furtuoso utilizou a matriz de insumo-produto para o Brasil elaborada pelo IBGE; essa matriz possui um bom nível de desagregação, permitindo que a autora realizasse seus testes utilizando-se de 43 setores. Isso permitiu que o setor químico fosse desagregado em 3 sub-setores, 17 - fabricação de elementos químicos (constituído basicamente por álcool de cana e de cereais); 18 - refino de petróleo; e 19 - fabricação de produtos químicos diversos. A autora considerou o sub-setor 17 (fabricação de elementos químicos) no cálculo do agronegócio. No caso das matrizes inter-regionais calculadas nessa Tese, os setores aparecem de forma mais agregada, pelo fato de não haver dados disponíveis. Sendo assim, optou-se por não incluir o setor química no cálculo da Produção Agroindustrial, pois o setor de álcool aparece agregado com o refino do petróleo, o que levaria a um erro nos cálculos. Por outro lado, pode-se esperar que o valor obtido para o agronegócio fique subestimado pela exclusão do setor de álcool; pois Guilhoto et al (1999) calcularam que o setor de fabricação de elementos químicos representa $3,7 \%$ do valor total do agronegócio brasileiro para 1995, considerando a distribuição final.

Outro setor que não fez parte do cálculo para o agronegócio nessa Tese é o setor de celulose, papel e gráfica. A justificativa também encontra-se na pesquisa de Furtuoso (1998). Os testes realizados pela autora demonstraram que esse setor utilizou, para os anos de 1980, 1985 e 1990, respectivamente, 2,08\%, 2,24\% e 2,51\% de insumos adquiridos do setor agropecuário no total de insumos utilizados pelo setor em seu 
processo produtivo; portanto, um valor bastante reduzido. A autora também não considerou esse setor como um dos componentes do agronegócio em sua pesquisa.

O valor da produção agroindustrial $(P A I)$ da região Sudeste é obtido pela seguinte expressão:

$$
P A I=V A_{7}-T_{7}
$$

Em que

$V A_{7}$ representa o valor adicionado a preço básico gerado pelo setor agroindustrial $T_{7}$ representa o valor dos impostos líquidos sobre atividade desembolsados pelo setor agroindustrial (impostos sobre atividade menos subsídios sobre atividade).

Da mesma forma que o agregado II, o setor de produção agroindustrial da região Sudeste também realiza exportações para a demanda intermediária $(D I)$ e para a demanda final $(D F)$ das outras regiões.

Essas exportações podem ser obtidas da seguinte maneira:

$$
\begin{array}{ll}
\text { Exportações } D I=\frac{V A_{7}}{X_{7}} Z_{7}^{O K} & (K=L, M, N, P) \\
\text { Exportações } D F=\frac{V A_{7}}{X_{7}} Y_{7}^{O K} & (K=L, M, N, P)
\end{array}
$$

onde

$V A_{7} / X_{7}$ representa a participação do valor adicionado do setor agroindustrial no valor bruto da produção do mesmo setor na região Sudeste.

$Z_{7}^{O K}$ representa os valores da demanda intermediária $(D I)$ para o setor agroindustrial da região Sudeste nas demais regiões do país.

$\mathrm{Y}_{7}^{\mathrm{OK}}$ representa os valores da demanda final $(D F)$ para o setor agroindustrial da região Sudeste nas demais regiões do país. 
Finalmente, calcula-se o valor referente à Distribuição Final $(D I F)$ do agronegócio da região Sudeste. Considera-se para este cálculo o valor agregado dos setores relativos ao "Transporte e Comércio" e do setor "Serviços".

Como o valor adicionado desses dois setores englobam todos os produtos do sistema econômico da região, deve-se fazer uma ponderação (ou rateio), destinando-se ao agronegócio apenas a parcela que corresponde à participação dos produtos agropecuários e produtos agroindustriais na demanda final de produtos da região.

Dessa forma, para estabelecer o valor da distribuição final $(D I F)$, deve-se partir do cálculo da produção interna $(P I)$ da região Sudeste:

$$
P I=D F G P-I I L-T P I
$$

onde

$D F G P$ é a demanda final global de produtos da região Sudeste;

IIL é o valor total dos impostos indiretos líquidos relacionados com a demanda final da região Sudeste

TPI é o valor total de produtos importados para a demanda final da região Sudeste originados das outras regiões do Brasil e do exterior.

O segundo passo envolve o cálculo da margem de comercialização $(M C)$ ou total da distribuição da região Sudeste:

$$
M C=V A_{16}-T_{16}+V A_{17}-T_{17}
$$

em que

$V A_{16}$ é o valor adicionado a preços básicos gerado pelo setor Transporte e comércio

$V A_{17}$ é o valor adicionado a preços básicos gerado pelo setor Serviços

$T_{16} \quad$ é o valor dos impostos líquidos sobre atividade pagos pelo setor Transporte $\mathrm{e}$ Comércio (impostos sobre atividade menos subsídios sobre atividade).

$T_{I 7}$ é o valor dos impostos líquidos sobre atividade pagos pelo setor Serviços (impostos sobre atividade menos subsídios sobre atividade). 
A seguir, estima-se a demanda final de produtos agropecuários (DFPA) e a demanda final de produtos do setor agroindustrial $(D F P A I)$ da região Sudeste:

$$
\begin{aligned}
& D F P A=Y_{1}^{O L}+Y_{1}^{O M}+Y_{1}^{O N}+Y_{l}^{O O}+Y_{1}^{O P} \\
& D F P A I=Y_{7}^{O L}+Y_{7}^{O M}+Y_{7}^{O N}+Y_{7}^{O O}+Y_{7}^{O P}
\end{aligned}
$$

O próximo passo é estimar o valor da Distribuição Final (DFI) correspondente às atividades dos setores agropecuário e agroindustrial da região Sudeste:

$$
D F I=\left(\frac{D F P A+D F P A I}{P I}\right) M C
$$

Finalmente, somando-se o valor da Produção Agroindustrial $(P A I)$ e o valor da Distribuição Final (DFI), chega-se ao total do agregado III ou jusante do agronegócio da região Sudeste:

Agregado $I I I=P A I+D F I$

onde

PAI é o valor da produção agroindustrial da região Sudeste;

DFI é o valor da distribuição final da agropecuária e agroindústria da região Sudeste Pode-se, então, representar a dimensão econômica do agronegócio da região Sudeste matematicamente, utilizando-se das equações (12), (13) e (24); através da seguinte expressão:

Agronegócio = Agregado I + Agregado II + Agregado III

ou

Agronegócio $=$ Montante + Produção rural + Jusante

Para encerrar este tópico, resta afirmar que a metodologia desenvolvida para o dimensionamento do agronegócio da região Sudeste do Brasil é, facilmente, adaptada para as demais regiões do país. Portanto, apesar da metodologia haver sido desenvolvida 
utilizando a região Sudeste como exemplo (para facilitar o desenvolvimento), serão apresentados resultados referentes a todas as regiões do Brasil.

Uma maneira de comparar o grau de desenvolvimento das regiões através da estrutura do agronegócio foi proposta por Malassis (1969). A avaliação proposta pelo autor considera a participação do agregado II (produção rural) no valor total e, consequentemente, a participação do agregado II e III (montante e jusante). Malassis classifica uma economia alimentar de pré-industrial ou agrícola nos casos em que o agregado I (montante) do agronegócio representa 5\% do valor do mesmo, o agregado III (jusante) representa $20 \%$ e o agregado II (produção rural) participa com $75 \%$. Uma economia atinge, segundo o autor, o nível de economia alimentar industrializada quando, por exemplo, o montante representa $17 \%$, a produção rural participa com $32 \%$ e, a jusante participa com $51 \%$ do valor total do agronegócio. Nesse sentido, quando o agregado II ou produção rural começa a participar com menos de um terço do valor total do agronegócio, a economia se eleva de um nível pré-industrial para uma economia industrializada. 


\section{A REGIONALIZAÇÃO DO AGRONEGÓCIO BRASILEIRO}

Neste capítulo, serão realizadas análises sobre as diferenças e semelhanças que existem entre as regiões brasileiras, no que se refere ao agronegócio; ou seja, será feita uma análise comparativa. Será determinada a participação de cada região na composição do agronegócio do Brasil para os anos de 1985, 1990 e 1995.

\subsection{A participação das regiões no agronegócio para o ano de 1985}

A primeira característica importante observada nos resultados obtidos é a diferença na constituição do agronegócio nas regiões brasileiras, bem como as grandes diferenças observadas na participação do agronegócio no Produto Interno Bruto (PIB) da região, que assume valores de $30,1 \%$ no Sudeste e de $67,2 \%$ na região Sul, para citar alguns exemplos; esses resultados podem ser observados na tabela 5.1. Essa tabela também apresenta a constituição do agronegócio para o Brasil, obtida da mesma matriz inter-regional das regiões brasileiras, através de sua agregação. Portanto, os resultados obtidos para o Brasil representam uma média ponderada dos resultados das regiões.

O agronegócio para o Brasil para o ano de 1985 assume, segundo os dados da pesquisa, um total de Cr $\$ 494.987$ bilhões em valores de 1985. Esse total representa uma participação de 38,6\% no PIB do país para aquele ano. Essa participação é confirmada pelo estudo de Furtuoso (1998), que chegou a um valor de 36,15\% (versão 3); e pelo 
estudo de Montoya \& Guilhoto (1999) que chegaram a uma participação do agronegócio de $38,89 \%$ para o ano de 1985 .

Desse total - na tabela 5.1, última linha - 16,48\% representam o agregado I ou montante do agronegócio, ou seja, as compras de insumos feitas pelos produtores rurais do país; $25,85 \%$ é constituído pelo agregado II ou produção rural e 57,66\% representam o agregado III ou jusante do agronegócio nacional; sendo que a jusante é dividida em produção agroindustrial (PAI), que representa 21,30\% do agronegócio, e distribuição final (DIF) que participa com $36,37 \%$.

Tabela 5.1: A constituição do agronegócio nas regiões brasileiras para o ano de 1985. Total em Cr\$ Bilhões.

\begin{tabular}{|c|c|c|c|c|c|c|c|c|c|}
\hline & & \multirow[t]{2}{*}{$\begin{array}{c}\text { Agregado } \\
\text { I }\end{array}$} & \multirow[t]{2}{*}{$\begin{array}{l}\text { Agregado } \\
\text { II }\end{array}$} & \multicolumn{3}{|c|}{$\begin{array}{l}\text { Agregado } \\
\text { III }\end{array}$} & \multirow[t]{2}{*}{$\begin{array}{l}\text { Agrone- } \\
\text { gócio }\end{array}$} & \multirow[t]{2}{*}{$\begin{array}{c}\text { PIB } \\
\text { regional }\end{array}$} & \multirow{2}{*}{$\begin{array}{c}\text { Agron/ } \\
\text { PIB } \\
(\%)\end{array}$} \\
\hline & & & & PAI & DIF & Total & & & \\
\hline Região & Total & 2804 & 6843 & 3390 & 4446 & 7836 & 17482 & 58086 & 30,10 \\
\hline Norte & $\%$ & 16,04 & 39,14 & 19,39 & 25,43 & 44,82 & 100,00 & & \\
\hline Região & Total & 9180 & 26419 & 13514 & 24085 & 37599 & 73197 & 193262 & 37,87 \\
\hline Nordeste & $\%$ & 12,54 & 36,09 & 18,46 & 32,90 & 51,37 & 100,00 & & \\
\hline Região & Total & 8404 & 11448 & 2640 & 10006 & 12646 & 32497 & 66916 & 48,56 \\
\hline C-Oeste & $\%$ & 25,86 & 35,23 & 8,12 & 30,79 & 38,91 & 100,00 & & \\
\hline Região & Total & 34378 & 47149 & 55483 & 90469 & 145951 & 227478 & 747570 & 30,43 \\
\hline Sudeste & $\%$ & 15,11 & 20,73 & 24,39 & 39,77 & 64,16 & 100,00 & & \\
\hline Região & Total & 26823 & 36113 & 30393 & 51003 & 81396 & 144332 & 214875 & 67,17 \\
\hline Sul & $\%$ & 18,58 & 25,02 & 21,06 & 35,34 & 56,39 & 100,00 & & \\
\hline BRASIL & Total & 81588 & 127971 & 105420 & 180008 & 285428 & 494987 & 1280709 & 38,65 \\
\hline & $\%$ & 16,48 & 25,85 & 21,30 & 36,37 & 57,66 & 100,00 & & \\
\hline
\end{tabular}

Fonte: Dados da pesquisa.

A tabela 5.1 permite comparar a importância de cada agregado na composição do agronegócio para as regiões do país. Nesse sentido, o agregado I assume maior importância para a região Centro-Oeste (CO) representando $25,86 \%$ do agronegócio dessa região e menor importância para a região Nordeste (NE) com 12,54\%. O agregado 
II (produção rural) assume grande importância na região Norte $(\mathrm{N})$ participando com $39,14 \%$ do agronegócio daquela região, ou seja, é uma região que apresenta pouco desenvolvimento dos setores a montante e a jusante do agronegócio, ao contrário da região Sudeste (SE), na qual a produção rural participa com $20,73 \%$, sendo a menor participação entre todas as regiões do país. Com relação ao agregado III a situação se inverte, na região SE ele representa $64,16 \%$ do agronegócio, sendo essa a maior participação entre as regiões do Brasil para o ano de 1985.

Quando analisa-se os componentes do agregado III, percebe-se a grande importância da agroindústria (PAI) para as regiões Sudeste e Sul, participando, respectivamente, com $24,39 \%$ e $21,06 \%$ do agronegócio regional, e também a importância do setor de comercialização ou distribuição final (DIF) com uma participação de $39,77 \%$ na região Sudeste e $35,34 \%$ na região Sul. A região CentroOeste apresenta uma agroindústria relativamente pequena, com uma participação da produção agroindustrial na composição do agronegócio para o ano de 1985 de 8,12\%, a menor entre as regiões do Brasil.

Com relação à participação do valor total do agronegócio no Produto Interno Bruto (PIB) das regiões deve-se destacar a região Sul do Brasil, na qual o agronegócio representa $67,17 \%$ do total de bens e serviços produzidos na região, esta participação deve-se, principalmente, ao agregado III que representa 56,39\% do agronegócio regional. A seguir aparece a região Centro-Oeste, com o agronegócio representando $48,56 \%$ do PIB da região, o destaque nessa região fica por conta do agregado I. Na região Nordeste, o agronegócio participa com $37,87 \%$ do PIB regional, e a produção rural assume um papel de grande importância nessa região. Finalmente, nas regiões Sudeste e Norte o agronegócio representa, respectivamente, $30,43 \%$ e $30,10 \%$ do total de bens e serviços produzidos, para o ano de 1985. Sendo essas as regiões em que o agronegócio assume menor importância para a economia regional.

A tabela 5.2 permite analisar a importância de cada região na composição do agronegócio do Brasil. Como se percebe, a região Sudeste é a mais importante em todos os agregados, tornando o agronegócio brasileiro extremamente concentrado nessa área 
do país. A importância econômica dessa região para o país é demonstrada no Capítulo 2 desta tese.

Vale destacar, entretanto, que apesar da região Sudeste apresentar grande importância na composição do agronegócio do país, essa importância não acompanha a importância econômica da região para o Brasil considerando todos os bens e serviços produzidos. As três últimas colunas da tabela 5.2 confirmam essa afirmativa, pois, enquanto a região participa com $45,96 \%$ do agronegócio do país, a sua participação na constituição do PIB brasileiro é de $58,37 \%$, ou seja, a importância do agronegócio eqüivale a $78,73 \%$ da importância da produção de bens e serviços da região em relação ao Brasil. A região Norte apresenta um comportamento semelhante, com o indicador da importância do agronegócio com relação à importância do PIB assinalando 77,87\%; entretanto, as proporções são bem inferiores àquelas apresentadas pela região Sudeste. Na região Nordeste, a importância, tanto do agronegócio regional quanto do PIB regional para a composição dos respectivos totais nacionais são equivalentes. Para as regiões Centro-Oeste e Sul a situação se inverte; pois a dimensão econômica do agronegócio das regiões para o Brasil é maior do que a participação do PIB regional no PIB total do país. Nesse sentido, o destaque fica com a região Sul, que participa com 29,16\% do agronegócio do Brasil, contra uma participação no PIB nacional de 16,78\%. A região Centro-Oeste participa com 6,57\% na composição do agronegócio do país, contra uma participação no PIB nacional de 5,22\% para o ano de 1985.

Analisando os agregados, observa-se que o consumo de insumos para a agricultura é maior nas regiões Sudeste, 42,14\%; e Sul, 32,88\%; conferindo a essas regiões uma participação de $75,0 \%$ no agregado I ou montante do agronegócio brasileiro. A participação das regiões no total da produção rural (agregado II) é mais bem distribuída, com destaque para o SE $(36,84 \%)$, o Sul $(28,22 \%)$ e para o Nordeste $(20,64 \%)$, sendo que os resultados obtidos são bem próximos àqueles apresentados na figura 11. O agregado III ou jusante do agronegócio brasileiro é o mais concentrado, com a região Sudeste participando com $51,13 \%$ do agregado e com mais da metade $(52,63 \%)$ da produção agroindustrial do país. A região Sul apresenta uma boa 
participação nesse agregado com $28,52 \%$. A região Norte participa com apenas $2,75 \%$ da jusante da agronegócio do país e a região Centro-Oeste colabora com apenas 2,50\% da produção agroindustrial brasileira.

Tabela 5.2: A participação das regiões na composição do agronegócio do Brasil. Ano de 1985. Total em Cr\$ Bilhões.

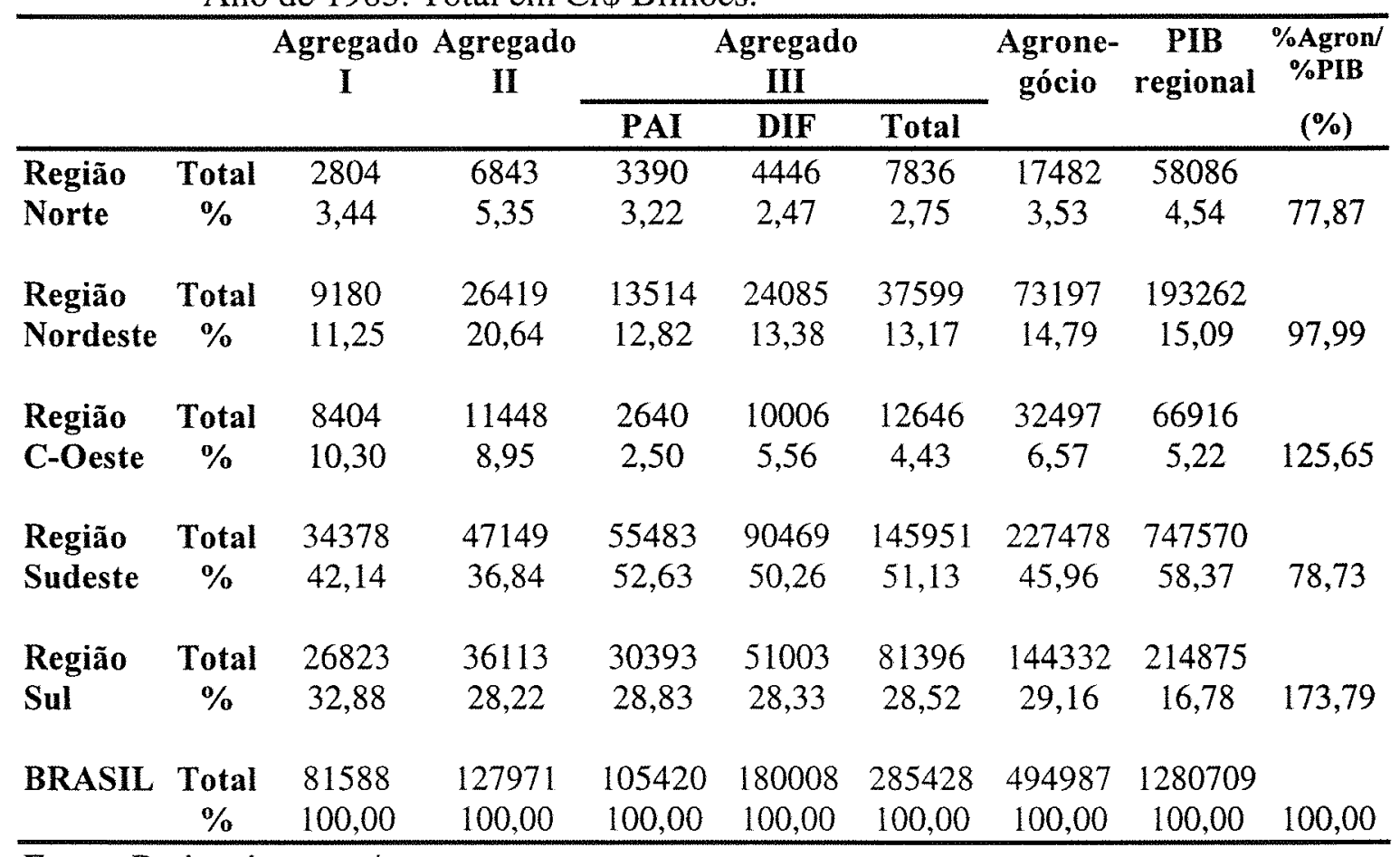

Fonte: Dados da pesquisa. 


\subsection{A participação das regiões no agronegócio para o ano de 1990}

Os resultados paro o ano de 1990 indicam que, comparando com 1985, ocorreram mudanças importantes na participação do agronegócio na composição do Produto Interno Bruto das regiões brasileiras e também na participação das regiões na composição do agronegócio do Brasil.

A constituição do agronegócio das regiões brasileiras paro o ano de 1990 está apresentada na tabela 5.3. Essa tabela também apresenta a constituição do agronegócio paro o Brasil, obtida da mesma matriz interregional das regiões do país, através de sua agregação.

O valor total do agronegócio brasileiro para o ano de 1990, segundo os dados da pesquisa, é de Cr\$ 9.842.607 milhões em valores daquele ano. Este valor é próximo do obtido por Montoya \& Guilhoto (1999) que foi de Cr\$9.827.931 milhões para o mesmo ano. Entretanto, a participação do agronegócio no PIB do país difere daquela obtida pelos autores citados. Enquanto nessa pesquisa chegou-se a uma participação de $30,98 \%$, Montoya \& Guilhoto (1999) chegaram numa participação de $36,47 \%$ para o ano de 1990. Obviamente, a diferença está no valor do PIB que foi utilizado para o cálculo, pois o valor total do agronegócio, como vimos, é praticamente o mesmo.

Quando comparado com o estudo de Furtuoso (1998), os resultados obtidos para a participação do agronegócio no PIB do Brasil são mais parecidos. Pois essa autora chegou a uma participação de $29,70 \%$ (versão 3) paro o ano de 1990, bem próximo aos $30,98 \%$ obtidos na presente pesquisa.

Analisando a tabela 5.3, percebe-se que ocorreram alterações nos componentes do agronegócio pois, comparando com 1985, houve uma diminuição na importância dos agregados I e II em favor do agregado III, que em 1990 representava 60,89\% do agronegócio do Brasil (última linha, tabela 5.3) contra uma participação de $57,66 \%$ em 1985. Interessante notar, que este aumento deve-se totalmente ao setor de distribuição final (DIF) (que aumentou sua participação de $36,37 \%$ para $41,00 \%$ ), pois o 
outro componente do agregado III, a produção agroindustrial, teve sua participação diminuída entre 1985 e 1990.

Este comportamento pode ser explicado pelo aumento da participação do setor de serviços na economia brasileira, o qual participava com 46,61\% do PIB nacional em 1985 e aumentou sua participação para 53,095 em 1990 (tabela 2.2, capítulo 2); pois o setor de distribuição final é fortemente relacionado com o setor de serviços pois envolve as atividades de transporte e comércio.

A última coluna da tabela 5.3, apresenta a participação do valor do agronegócio no PIB das regiões. Percebe-se que a mesma tendência de diminuição da importância do agronegócio na economia vista para o Brasil reflete-se em suas regiões, com exceção da região Norte que apresentou um pequeno aumento de $30,10 \%$ para $31,18 \%$ entre 1985 e 1990.

Tabela 5.3: A constituição do agronegócio nas regiões brasileiras para o ano de 1990. Total em Cr\$ Milhões.

\begin{tabular}{|c|c|c|c|c|c|c|c|c|c|}
\hline & & $\begin{array}{c}\text { Agregado } \\
\text { I }\end{array}$ & $\begin{array}{l}\text { Agregado } \\
\text { II }\end{array}$ & & $\begin{array}{c}\text { Agregado } \\
\text { III }\end{array}$ & & $\begin{array}{l}\text { Agrone- } \\
\text { gócio }\end{array}$ & $\begin{array}{l}\text { PIB } \\
\text { regional }\end{array}$ & $\begin{array}{c}\text { Agron } \\
\text { PIB }\end{array}$ \\
\hline & & & & PAI & DIF & Total & & & $(\%)$ \\
\hline Região & Total & 89553 & 179639 & 96467 & 130051 & 226518 & 495710 & 1589859 & 31,18 \\
\hline Norte & $\%$ & 18,07 & 36,24 & 19,46 & 26,24 & 45,70 & 100,00 & & \\
\hline Região & Total & 213372 & 532214 & 226579 & 548678 & 775257 & 1520843 & 4909441 & 30,98 \\
\hline Nordeste & $\%$ & 14,03 & 34,99 & 14,90 & 36,08 & 50,98 & 100,00 & & \\
\hline Região & Total & 174547 & 233820 & 68204 & 231273 & 299478 & 707845 & 1934112 & 36,60 \\
\hline C-Oeste & $\%$ & 24,66 & 33,03 & 9,64 & 32,67 & 42,31 & 100,00 & & \\
\hline Região & Total & 628827 & 782936 & 965160 & 1969147 & 2934308 & 4346070 & 18174846 & 23,91 \\
\hline Sudeste & $\%$ & 14,47 & 18,01 & 22,21 & 45,31 & 67,52 & 100,00 & & \\
\hline Região & Total & 442901 & 571822 & 601142 & 1156273 & 1757416 & 2772139 & 5161625 & 53,71 \\
\hline Sul & $\%$ & 15,98 & 20,63 & 21,69 & 41,71 & 63,40 & 100,00 & & \\
\hline BRASIL & Total & 1549200 & 2300430 & 1957553 & 4035423 & 5992976 & 9842607 & 31769881 & 30,98 \\
\hline & $\%$ & 15,74 & 23,37 & 19,89 & 41,00 & 60,89 & 100,00 & & \\
\hline
\end{tabular}

Fonte: Dados da pesquisa. 
As demais regiões apresentaram grande diminuição da importância do agronegócio entre os dois períodos, com destaque para as regiões Sul e Centro-Oeste que apresentaram as maiores variações, caindo de $67,17 \%$ e $48,56 \%$, respectivamente, para $53,71 \%$ e $36,60 \%$. Outro destaque deve ser feito para a região Sudeste que, para o ano de 1990, apresenta a menor participação do agronegócio no PIB regional com apenas $23,91 \%$.

A tabela 5.3 permite, ainda, comparar a importância de cada agregado na composição do agronegócio nas regiões do Brasil para 1990. Assim, O agregado I assume maior importância para a região Centro-Oeste representando $24,66 \%$ do agronegócio dessa região, confirmando o resultado obtido para 1985. O agregado II continua sendo de grande importância para a região Norte participando com $36,24 \%$ do agronegócio daquela região, confirmando ser esta a região que apresenta o menor desenvolvimento dos setores à montante e à jusante do agronegócio. No agregado III as regiões Sudeste e Sul com, respectivamente, 67,52\% e 63,40\% do agronegócio são as que apresentam as maiores participações.

A análise dos componentes do agregado III mostra a importância da produção agroindustrial para as regiões Sudeste, Sul e Norte, e também a importância da distribuição final para as regiões Sudeste e Sul. Novamente, como ocorreu em 1985, a agroindústria da região Centro-Oeste apresenta pouca importância na constituição do agronegócio regional, com uma participação de 9,64\% no agronegócio para o ano de 1990, continuando a menor entre as regiões do Brasil.

A tabela 5.4 apresenta a importância de cada região na composição do agronegócio brasileiro para o ano de 1990. A região Sudeste continua apresentando uma maior participação em todos os agregados, entretanto, quando se compara com os resultados obtidos para 1985, percebe-se uma diminuição da participação dessa região em todos os agregados. Ou seja, ocorreu um processo de desconcentração do agronegócio brasileiro entre 1985 e 1990.

A região Sudeste participa em $1990 \mathrm{com} 44,16 \%$ do valor total do agronegócio brasileiro, contra uma participação de 45,96\% em 1985. Outra região que 
apresentou diminuição de sua importância foi a região Sul, 29,16\% em 1985 contra $28,16 \%$ em 1990. As demais regiões apresentaram um aumento da participação entre os dois períodos; a região Norte aumentou sua parcela de 3,53\% para 5,04\%; a região Nordeste aumentou sua participação de $14,79 \%$ para $15,45 \%$ e a parcela da região Centro-Oeste foi de $6,57 \%$ para $7,19 \%$.

Quando se analisa o comportamento dos agregados, percebe-se que no agregado I ou montante do agronegócio ocorreu aumento da participação das regiões Norte, Nordeste e Centro-Oeste e diminuição das parcelas das regiões Sudeste e Sul. Sendo assim, a participação dessas duas últimas regiões nesse agregado, que em 1985 era de $75,0 \%$, representa $69,2 \%$ para o ano de 1990 . Este comportamento repete-se no agregado II, sendo que em 1985 a parcela das regiões Sudeste e Sul representava 65,0\% e diminuiu para 59,0\% em 1990.

O comportamento do agregado III é um pouco diferente, ocorreu desconcentração através da diminuição da parcela da região Sudeste de 51,13\% em 1985 para 48,96\% em 1990. Porém, nesse agregado, todas as regiões aumentaram sua participação inclusive a região Sul. Vale destacar que, apesar das alterações ocorridas, a participação da região Norte continua reduzida, com apenas 3,78\% do agregado III e a região Centro-Oeste contribui com 3,48\% da produção agroindustrial do Brasil.

Ao analisar-se, através das últimas colunas da tabela 5.4, a relação entre a importância do agronegócio regional e a importância do PIB regional para o país verifica-se que, para o ano de 1990, os comportamentos são semelhantes àqueles obtidos para o ano de 1985. Ocorrendo uma significativa alteração apenas na região Norte, onde a dimensão econômica do agronegócio da região para o país atingiu a mesma importância PIB da região para o país, ao redor de 5,0\%. 
Tabela 5.4: A participação das regiões na composição do agronegócio do Brasil. Ano de 1990. Total em Cr\$ Milhões.

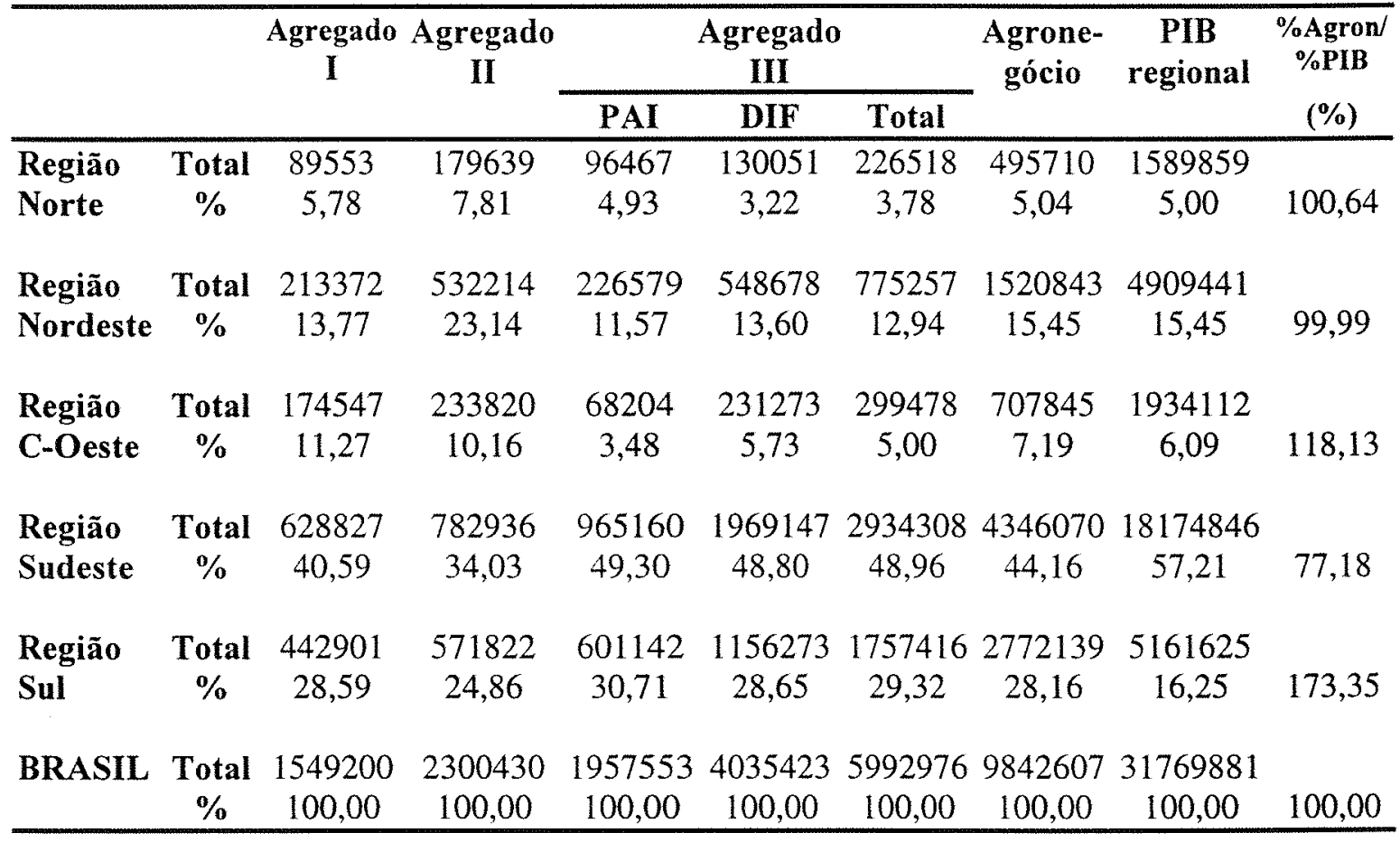

Fonte: Dados da pesquisa. 


\subsection{A participação das regiões no agronegócio para o ano de 1995}

Os resultados obtidos para o ano de 1995 apontam para a continuidade do processo de desconcentração regional do agronegócio brasileiro. Outra tendência que se mantém é a da diminuição da participação do agronegócio na composição do Produto Interno Bruto da regiões do país.

A tabela 5.5 apresenta a constituição do agronegócio das regiões brasileiras paro o ano de 1995. Essa tabela também apresenta a constituição do agronegócio paro o Brasil, obtida da mesma matriz interregional das regiões do país, através de sua agregação.

Essa tabela indica que o valor total do agronegócio brasileiro para o ano de 1995 , segundo os dados da pesquisa, é de $\mathrm{R} \$ 176.956 .569 .000 \mathrm{em}$ valores correntes. $\mathrm{Na}$ última coluna da tabela está indicada a participação do agronegócio no Produto Interno Bruto do país, que foi de 30,43\% em 1995.

Montoya \& Guilhoto (1999) obtiveram um valor de R $\$ 181.655 .020 .000$ para o agronegócio brasileiro em 1995, com uma participação no PIB de 33,29\%. Assim como ocorreu em 1990, supõe-se que a diferença entre os resultados obtidos pelos autores e os resultados obtidos na presente pesquisa está no valor do PIB que foi utilizado para o cálculo, pois o valor do agronegócio é bem próximo em ambas as pesquisas.

Furtuoso (1998) apresenta um resultado indicando que a participação do agronegócio no PIB brasileiro, para o ano de1994, foi de 31,71\% (versão 3).

A análise dos componentes do agronegócio mostra uma inversão na tendência de aumento da participação do agregado III na composição do agronegócio brasileiro. Em 1995 esse agregado representava 52,85\% do agronegócio última linha, tabela 5.5) contra uma participação de $60,89 \%$ em 1990. Por outro lado, os agregados I e II apresentam um aumento de importância de um período para o outro.

Novamente, esses resultados são confirmados pelas pesquisas que analisam o agronegócio do Brasil. Para Montoya \& Guilhoto (1999), o agregado III (jusante) 
representava 60,13\% em 1990 diminuindo sua participação para 54,15\% em 1995 . Furtuoso (1998) também detecta essa mudança para o ano de 1994 (a autora não possui resultados para além desse ano). Sobre esse fato, a autora argumenta: "Contudo, cabe assinalar que o ano de 1994 traz uma perspectiva nova para a evolução do CAI. A agropecuária registra um aumento de participação no PIB, em torno de 8 pontos percentuais....Em contrapartida, o segmento a jusante apresenta redução da participação no PIB, passando de $66,1 \%$ para $58,1 \%$ (versão 3 )....Trata-se de uma reação importante da agropecuária às mudanças no contexto nacional. Contudo, os fatores explicativos desse fenômeno devem ainda ser melhor estudados....".

A última coluna da tabela 5.5, apresenta a participação do valor do agronegócio no PIB das regiões. Percebe-se que a tendência de diminuição da importância do agronegócio na economia vista para o período 1985/1990 continua acontecendo no período 1990/1995, com exceção da região Centro-Oeste que apresentou um aumento de 36,60\% para 38,14\% entre 1990 e 1995.

As outras regiões continuaram apresentando diminuição da importância do agronegócio entre os dois períodos de análise, com destaque para as regiões Norte e Nordeste, nas quais a parcela do agronegócio no PIB regional fica abaixo de $30 \%$, juntamente com a região Sudeste na qual essa parcela é de $23,19 \%$, a menor entre todas as regiões do país.

Ao analisar-se a importância de cada agregado na composição do agronegócio nas regiões do Brasil para 1995, percebe-se que a diminuição da importância do agregado III vista para o Brasil, também ocorre em todas as regiões do país. Sendo que as maiores quedas ocorreram nas regiões Centro-Oeste, Sudeste e Sul. Na região CentroOeste a parcela do agregado III caiu de $42,31 \%$ para $32,31 \%$ entre os anos de 1990 e 1995, na região Sudeste a queda foi de $67,52 \%$ para 61,345 e na região Sul foi de $63,40 \%$ para $50,24 \%$, respectivamente, entre 1990 e 1995 . O segmento mais favorecido com essa diminuição foi o agregado II, atingindo importante participação em algumas regiões com destaque para a regiões Norte, Nordeste e Centro-Oeste. Na região Norte, 
por exemplo, a produção agropecuária (agregado II) atinge uma parcela de $40,14 \%$ do agronegócio para o ano de 1995.

A análise dos componentes do agregado III apresenta a produção agroindustrial com destaque nas regiões Sul, Sudeste e Norte, e também a importância da distribuição final para as regiões Sudeste e Nordeste. Novamente, como ocorreu em 1985 e 1990, a agroindústria da região Centro-Oeste apresenta pouca importância na constituição do agronegócio da região, participando com $7,24 \%$ no agronegócio para o ano de 1995, a menor entre as regiões do Brasil.

Tabela 5.5: A constituição do agronegócio nas regiões brasileiras para o ano de 1995. Total em R\$ Mil.

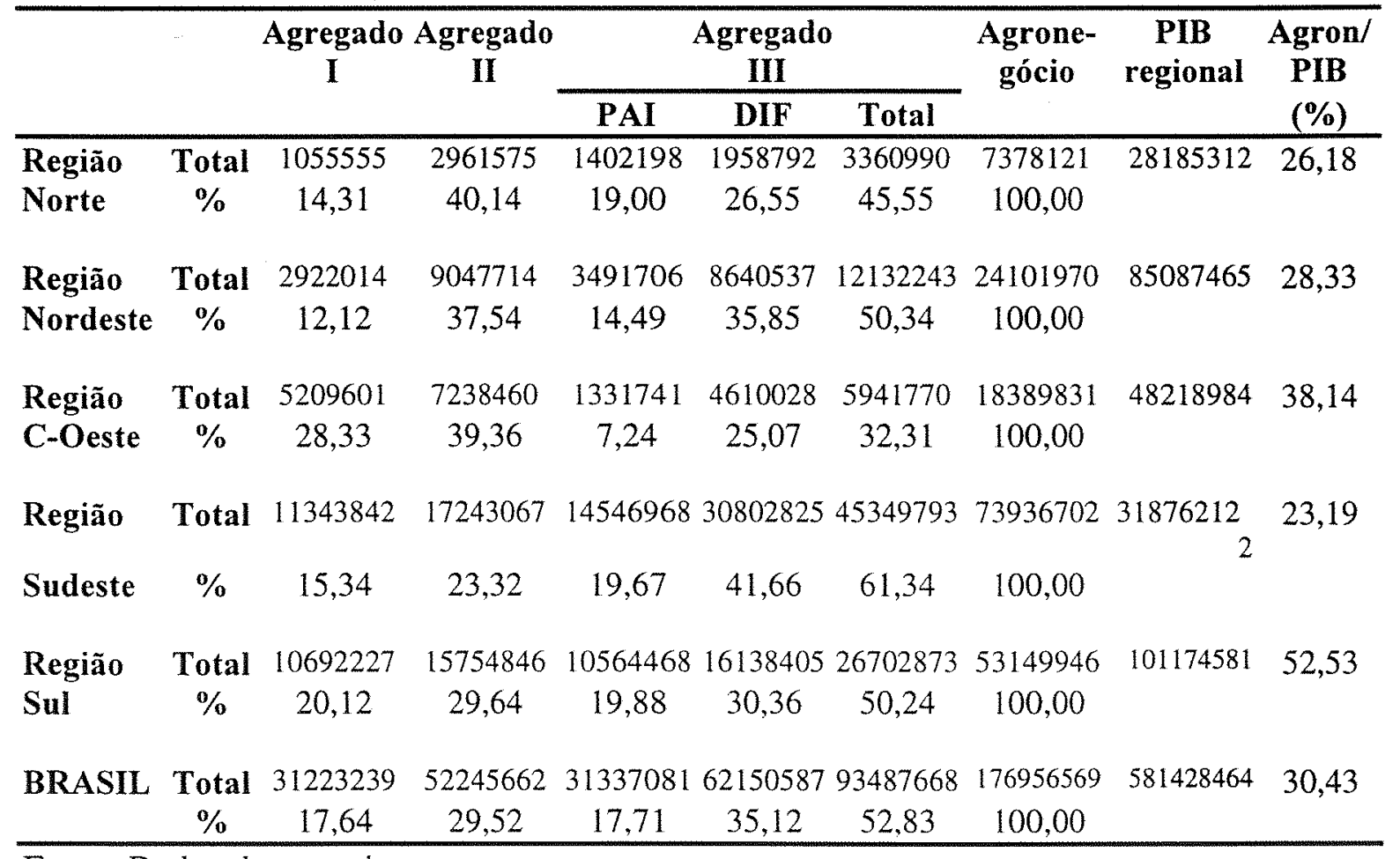

Fonte: Dados da pesquisa.

A tabela 5.6 apresenta a parcela de cada região na composição do agronegócio brasileiro para o ano de 1995. O processo de desconcentração continua atuando no setor, com a região Sudeste perdendo participação. Entretanto, quando comparado com os resultados obtidos para 1990, percebe-se que em 1995 não foram todas as regiões que se 
beneficiaram do processo, ocorrendo um direcionamento em favor das regiões Sul e Centro-Oeste e uma diminuição das parcelas das regiões Norte e Nordeste.

A região Sudeste participa em 1995 com $41,78 \%$ do valor total do agronegócio brasileiro, contra uma participação de 44,16\% em 1990. Também apresentaram diminuição de sua importância as regiões Norte, 5,04\% em 1990 contra 4,17\% em 1995 e a região Nordeste, caindo de 15,45\% em 1990 para 13,62\% em 1995. As demais regiões apresentaram um aumento da participação entre os dois períodos; a região Sul aumentou sua parcela de $28,16 \%$ para $30,04 \%$ e a parcela da região CentroOeste foi de 7,19\% para $10.39 \%$ entre 1990 e 1995.

A análise dos segmentos mostra que no agregado I (montante) do agronegócio ocorreu um grande aumento da parcela das regiões Centro-Oeste e Sul e uma diminuição da participação das demais regiões. Ainda assim, a parcela das regiões Sudeste e Sul atinge 70,57\% desse agregado para 1995, superior ao alcançado no período de 1990 que foi de 69,2\%. O mesmo ocorreu no agregado II (produção agrícola), sendo que em 1990 a parcela das regiões Sudeste e Sul representava 59,0\% e aumentou para 63,2\% em 1995. O que se verifica é que o crescimento da região Sul foi superior à queda da região Sudeste, diminuindo a diferença entre as duas regiões na composição desses segmentos do agronegócio brasileiro.

O agregado III apresentou uma diminuição da parcela das regiões Sudeste e Sul e um aumento da participação das demais regiões do país. Entretanto, as regiões Sudeste e Sul continuam dominando $77,1 \%$ desse segmento (agregado III) do agronegócio do país e $80,1 \%$ da produção agroindustrial brasileira.

Ao comparar-se a importância do agronegócio e do PIB da região na constituição dos respectivos agregados nacionais, verifica-se, para 1995, que as únicas regiões onde a importância do agronegócio é superior à importância do PIB para o país são as regiões Sul e Centro-Oeste. Esta conclusão pode ser verificada pelas últimas colunas da tabela 5.6, onde percebe-se que a região Sul participa com 30,04\% do agronegócio do Brasil, contra uma parcela no PIB nacional de $17,4 \%$. A região Centro- 
Oeste colabora com 10,39\% do valor total do agronegócio brasileiro, contra uma participação no PIB nacional de 8,29\% para o ano de 1995.

Tabela 5.6: A participação das regiões na composição do agronegócio do Brasil. Ano de 1995. Total em R\$ Mil.

\begin{tabular}{|c|c|c|c|c|c|c|c|c|c|}
\hline & & \multirow{2}{*}{\multicolumn{2}{|c|}{$\begin{array}{c}\text { Agregado Agregado } \\
\text { I }\end{array}$}} & \multicolumn{3}{|c|}{ Agregado III } & \multirow{2}{*}{$\begin{array}{l}\text { Agrone- } \\
\text { gócio }\end{array}$} & \multirow{2}{*}{$\begin{array}{c}\mathrm{PIB} \\
\text { regional }\end{array}$} & \multirow{2}{*}{$\begin{array}{c}\text { \%Agro/ } \\
\text { \%PIB } \\
(\%)\end{array}$} \\
\hline & & & & PAI & DIF & Total & & & \\
\hline Região & Total & 1055555 & 2961575 & 1402198 & 1958792 & 3360990 & 7378121 & 28185312 & \\
\hline Norte & $\%$ & 3,38 & 5,67 & 4,47 & 3,15 & 3,60 & 4,17 & 4,85 & 86,01 \\
\hline Região & Total & 2922014 & 9047714 & 3491706 & 8640537 & 12132243 & 24101970 & 85087465 & \\
\hline Nordeste & $\%$ & 9,36 & 17,32 & 11,14 & 13,90 & 12,98 & 13,62 & 14,63 & 93,07 \\
\hline Regiãa & Total & 5209601 & 7238460 & 1331741 & 4610028 & 5941770 & 18389831 & 48218984 & \\
\hline C-Oeste & $\%$ & 16,69 & 13,85 & 4,25 & 7,42 & 6,36 & 10,39 & 8,29 & 125,31 \\
\hline Regi & Total & 11343842 & 17243067 & 14546968 & 30802825 & 45349793 & 73936702 & 318762122 & \\
\hline Sudeste & $\%$ & 36,33 & 33,00 & 46,42 & 49,56 & 48,51 & 41,78 & 54,82 & 76,21 \\
\hline Regi & Total & 10692227 & 15754846 & 10564468 & 16138405 & 26702873 & 53149946 & 101174581 & \\
\hline Sul & $\%$ & 34,24 & 30,16 & 33,71 & 25,97 & 28,56 & 30,04 & 17,40 & 172,61 \\
\hline BRASIL & $\begin{array}{c}\text { Total } \\
\%\end{array}$ & $\begin{array}{c}31223239 \\
100,00\end{array}$ & $\begin{array}{c}52245662 \\
100,00 \\
\end{array}$ & $\begin{array}{c}31337081 \\
100,00\end{array}$ & $\begin{array}{c}62150587 \\
100,00\end{array}$ & $\begin{array}{c}93487668 \\
100,00\end{array}$ & $\begin{array}{c}176956569 \\
100,00\end{array}$ & $\begin{array}{c}581428464 \\
100,00 \\
\end{array}$ & 100,00 \\
\hline
\end{tabular}

Fonte: Dados da pesquisa. 


\subsection{Considerações finais}

A partir das informações sobre a participação das macrorregiões na constituição do agronegócio brasileiro e da composição do agronegócio dentro das regiões, apresentadas nas seções anteriores desse capítulo, pode-se levantar algumas observações sobre as alterações que ocorreram no período compreendido na análise, ou seja, 1985, 1990 e 1995. As conclusões mais importantes são:

a) Ocorreu uma desconcentração no agronegócio total e em seus segmentos (agregado I, II e III) entre 1985 e 1995.

b) Ocorreu uma diminuição generalizada da relação agronegócio/PIB, tanto para o Brasil quanto para suas macrorregiões, entre 1985 e 1995.

c) Observa-se grandes diferenças na composição do agronegócio entre as regiões do Brasil.

A figura 5.1 apresenta o processo de desconcentração interregional que ocorreu no agronegócio brasileiro no período de 1985 a 1995. A região Sudeste, que detinha 46,0\% do agronegócio em 1985, passou a concentrar 44,2\% em 1990 e 41,2\% em 1995; já na região Sul, essas mesmas participações eram, respectivamente, 29,2\%, 28,2\% e 30,0\%; no Nordeste, $14,8 \%, 15,4 \%$ e 13,6\%; na região Centro-Oeste, 6,6\%, 7,2\% e $10,4 \%$; e na região Norte, $3,5 \%, 5,0 \%$ e $4,2 \%$.

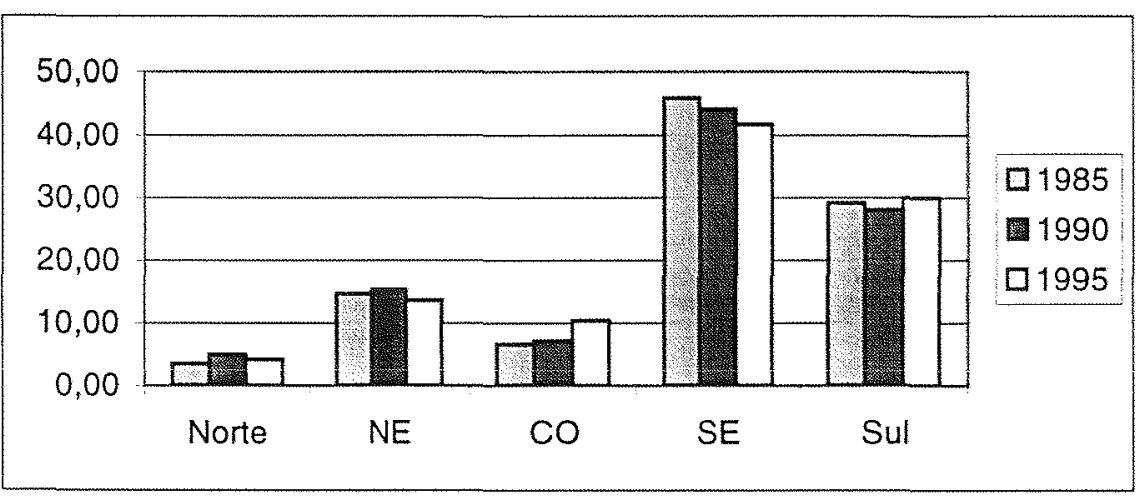

Fonte: Dados da pesquisa.

Figura 5.1: Participação das regiões no valor total do agronegócio do Brasil, em \%. 
Percebe-se uma contínua diminuição na parcela da região Sudeste no valor total do agronegócio do país a favor de um aumento nas participações das regiões Norte, Sul e Centro-Oeste, principalmente dessa última. A região Nordeste apresentou aumento de sua parcela no período 1985/1990 e diminuição no período 1990/1995; sendo que o resultado final (1985/1995) acabou indicando uma diminuição em sua participação.

Outra conclusão possível, analisando a figura 5.1 , é de que, apesar de estar ocorrendo um processo de desconcentração, o agronegócio brasileiro é extremamente concentrado nas regiões Sudeste e Sul do país. Juntas, essas regiões concentram, para os anos de 1985,1990 e 1995 , respectivamente, $75,1 \%, 72,3 \%$ e $71,8 \%$ do valor total do agronegócio do país.

As alterações ocorridas no total do agronegócio refletem-se nos seus agregados, ou seja, verifica-se que ocorre um processo de desconcentração nos segmentos do agronegócio brasileiro, porém, com magnitude diferentes. Pode-se dizer que as maiores alterações deram-se no agregado I ou montante e no agregado II ou produção agropecuária; enquanto o agregado III ou jusante do agronegócio pouco se alterou no período 1985/1995. Entretanto a produção agroindustrial, um dos componentes do agregado III, apresentou tendência à desconcentração no período da análise.

Estes comentários são confirmados pelas figuras 5.2, 5.3 e 5.4. A primeira dessas figuras apresenta as alterações nas participações das regiões na composição do agregado I; a região Sudeste que concentrava $42,1 \%$ desse segmento em 1985, teve sua parcela diminuída para 40,6\% em 1990 e para 36,3\% em 1995; enquanto na região Sul, essas mesmas participações foram, respectivamente, $32,9 \%, 28,6 \%$ e 34,2\%; na região Centro-Oeste, $10,3 \%, 11,3 \%$ e $16,7 \%$; na região Nordeste, $11,2 \%, 13,8 \%$ e $9,36 \%$; e na região Norte, $3,4 \%, 5,8 \%$ e $3,4 \%$.

Pode-se dizer, segundo a figura 5.2, que o consumo de insumos para a agropecuária brasileira apresentou uma tendência em deslocar-se da região Sudeste para as regiões Sul e Centro-Oeste, porém, o Sudeste continua com a maior parcela do segmento em 1995 (36,3\%), seguido de perto pela região Sul $(34,2 \%)$. 


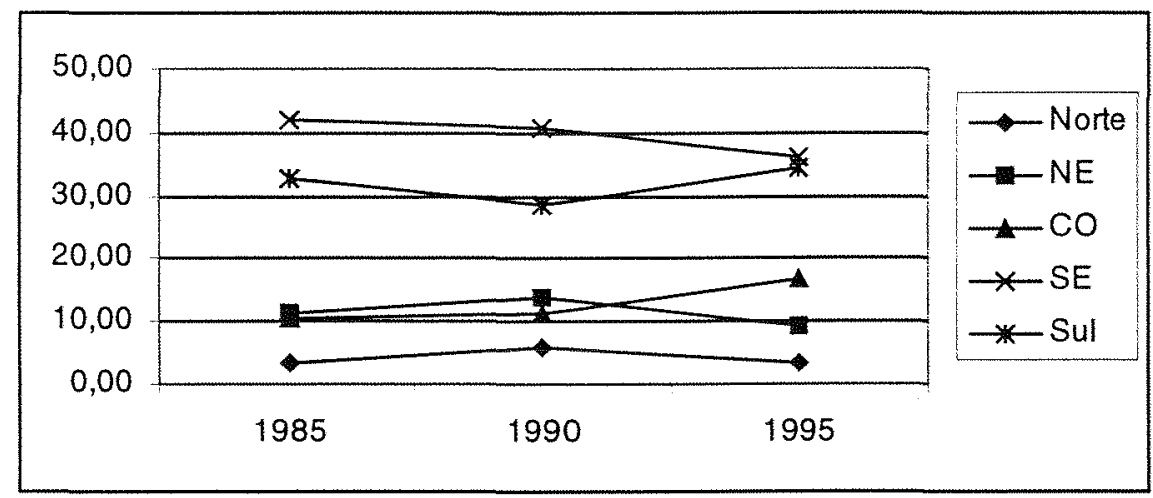

Fonte: Dados da pesquisa.

Figura 5.2: Participação das regiões no valor do agregado I (montante) do agronegócio brasileiro, em \%.

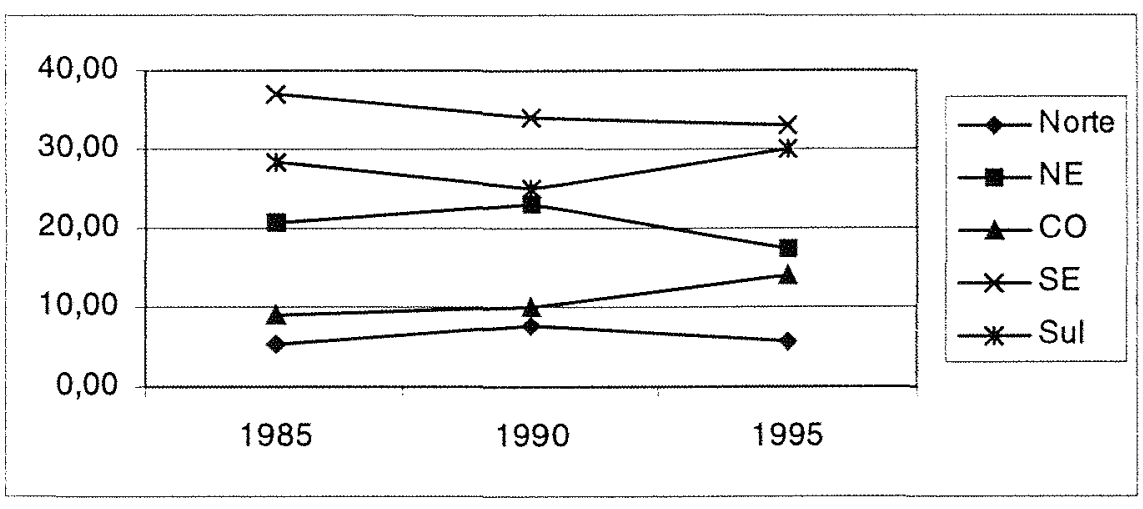

Fonte: Dados da pesquisa.

Figura 5.3: Participação das regiões no valor do agregado II (produção agropecuária) do agronegócio brasileiro, em \%.

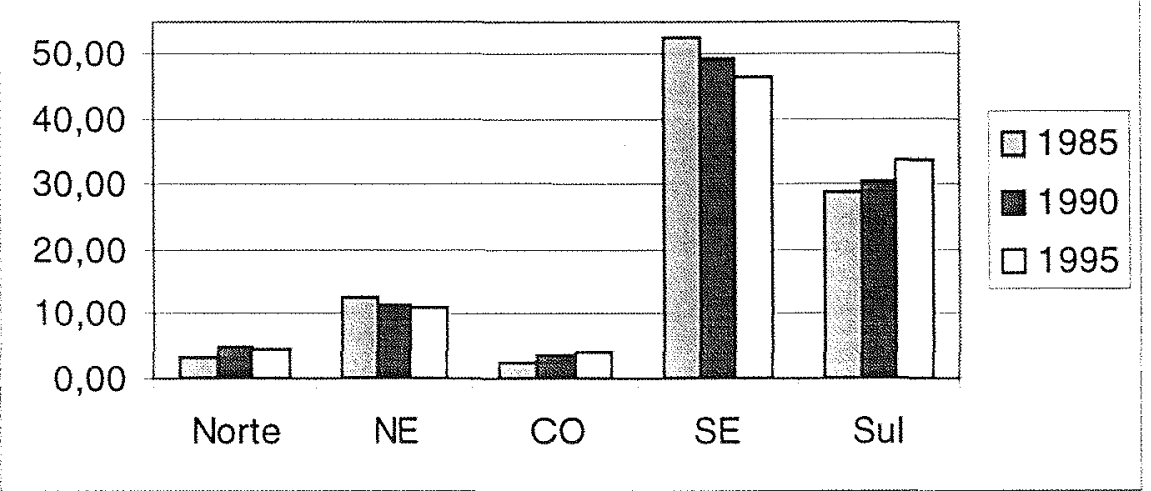

Fonte: Dados da pesquisa.

Figura 5.4: Participação das regiões no valor da produção agroindustrial (PAI) do Brasil, em $\%$. 
Outro resultado importante observado na figura 5.2 é o fato da região Nordeste apresentar uma participação superior à região Centro-Oeste no agregado I para os anos de 1985 e 1990, ou seja, houve um maior consumo de insumos pela região Nordeste nesse período. Esse resultado é, em parte, confirmado pelos dados dos Censos Agropecuários. Segundo o Censo Agropecuário de 1985 (IBGE, 1991a), a região Nordeste teve um parcela de $14,54 \%$ nas despesas totais da agropecuária brasileira, enquanto a região Centro-Oeste participou com 13,2\% (tabela 96, página 307 do Censo). O Censo Agropecuário de 1995-96 (IBGE, 1998), demonstra que houve uma inversão no posicionamento das regiões; o Centro-Oeste participou com $14,9 \%$ do total de despesas da agropecuária brasileira, contra uma participação de 12,1\% do Nordeste.

A figura 5.3 apresenta as alterações ocorridas no agregado II entre os anos de 1985 e 1995. Percebe-se que a magnitude do processo de concentração é diferente do observado para o segmento anterior. Isso deve-se ao fato das atividades agropecuárias apresentarem-se mais dispersas no território nacional, já antes de 1985. E o processo de desconcentração nesse segmento prossegue até 1995, com a região Sudeste perdendo quase 4 por cento de participação, 36,8\% em 1985 contra 33,0\% em 1995. Este comportamento também pode ser observado na figura 11 do capítulo 2.

A produção agroindustrial brasileira também apresentou alteração na distribuição no valor de sua produção entre as regiões brasileiras, como pode ser observado na figura 5.4. A tendência indica uma diminuição da parcela da região Sudeste em favor das regiões Norte, Centro-Oeste e Sul. Sendo que a participação do Nordeste pouco se altera no período analisado.

A região Sudeste contribuía com $52,6 \%$ da produção agroindustrial em 1985, sua parcela diminuiu para 49,3\% em 1990 e para 46,4\% em 1995; enquanto na região Sul, essas mesmas participações foram, respectivamente, $28,8 \%, 30,7 \%$ e $33,7 \%$; na região Nordeste, $12,8 \%, 11,6 \%$ e $11,1 \%$; na região Norte, $3,2 \%, 4,9 \%$ e $4,5 \%$; e na região Centro-Oeste, $2,5 \%, 3,5 \%$ e $4,2 \%$.

Percebe-se, portanto, uma desconcentração da produção agroindustrial brasileira. Porém o segmento continua situado nas regiões Sudeste e Sul sendo que, em 
1995, 80,0\% do valor da produção agroindustrial ainda estava nessas duas regiões do Brasil. O fato é que, apesar das regiões Centro-Oeste e Norte terem aumentado suas participações no total do agronegócio e também nos agregados I e II, o impacto sobre o desenvolvimento do setor agroindustrial foi proporcionalmente menor.

Outro aspecto importante observado nos resultados obtidos é quanto às alterações que ocorreram na participação do agronegócio na composição do Produto Interno Bruto das regiões brasileiras e também do Brasil no período 1985/1990.

É fácil verificar, através da figura 5.5, que ocorreu uma diminuição da importância do valor do agronegócio na constituição do valor total de bens e serviços produzidos no território brasileiro e nas regiões do país.

A maior diminuição ocorreu na região Sul, que apresentava uma relação agronegócio/PIB de 67,2\% em 1985, essa relação diminuiu para 53,7\% em 1990 e para 52,5\% em 1995; enquanto na região Centro-Oeste, essas mesmas relações foram, respectivamente, $48,6 \%, 36,6 \%$ e $38,1 \%$; na região Nordeste, $37,9 \%, 31,0 \%$ e $28,3 \%$; na região Norte, $30,1 \%, 31,2 \%$ e $26,2 \%$; e na região Sudeste, $30,4 \%, 23,9 \%$ e $23,2 \%$. O total para o Brasil também seguiu a mesma tendência de diminuição da relação agronegócio/PIB, apresentando uma participação de 38,6\% em 1985, 31,0\% em 1990 e 30,4\% em 1995.

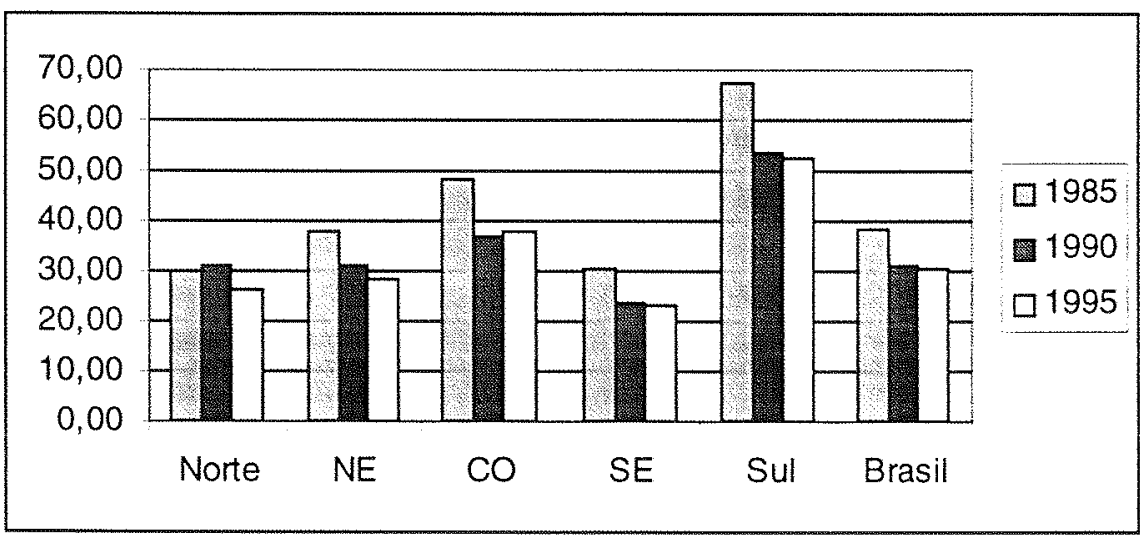

Fonte: Dados da pesquisa.

Figura 5.5: Participação do agronegócio na composição do PIB das regiões e do Brasil, em $\%$. 
Deve-se salientar que, apesar da participação do agronegócio no PIB estar diminuindo, o valor absoluto do agronegócio está aumentando, como demonstraram, para o Brasil, Montoya \& Guilhoto (1999). O que ocorre é que o valor absoluto do PIB está crescendo a uma taxa maior que a taxa de crescimento do agronegócio, devido à dinâmica dos outros complexos industriais como o metalúrgico, o automobilístico, etc.; e também às mudanças estruturais originadas do processo de abertura comercial do início da década de 90 .

A análise das diferenças na composição do agronegócio entre as regiões do país (tópico c) exige uma análise mais detalhada, que será feita no próximo capítulo. 


\section{A COMPOSIÇÃO DO AGRONEGÓCIO DAS REGIÕES BRASILEIRAS}

Neste capítulo pretende-se aprofundar a análise sobre o agronegócio das regiões brasileiras, tratando-as de modo isolado. A atenção será voltada para a análise da constituição do agronegócio das regiões, ou seja, qual a participação de cada agregado na constituição do agronegócio regional.

Inicialmente, será realizada uma análise do comportamento do agronegócio do Brasil pois, algumas alterações que ocorrem em nível nacional também são verificadas nas regiões do país. A principal dessas variações é a diminuição da participação do valor total do agronegócio na composição do Produto Interno Bruto (PIB), como pode ser verificado na figura 6.1 .

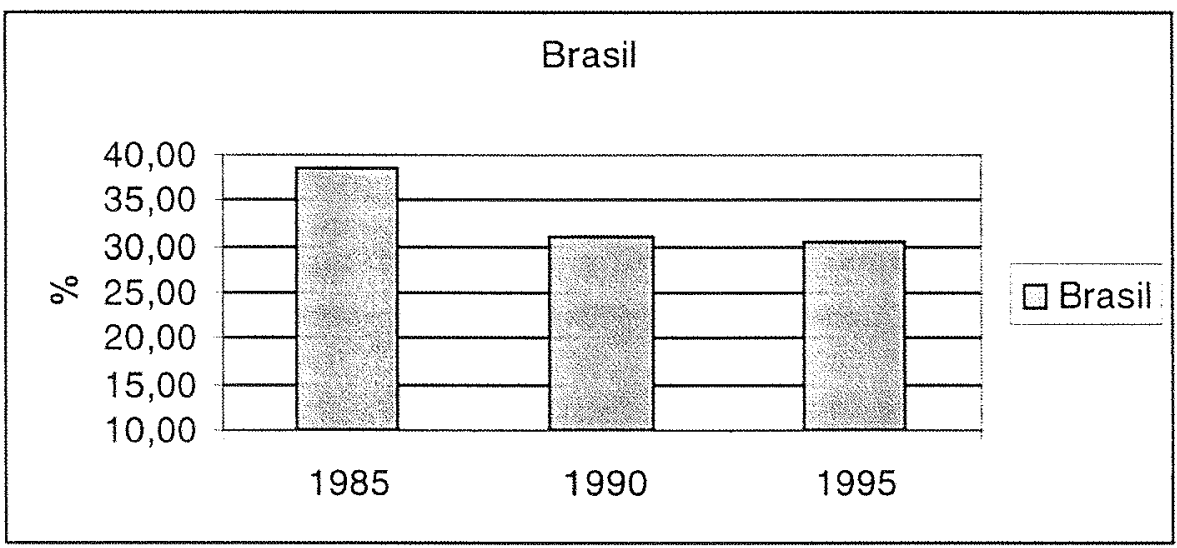

Fonte: Dados da pesquisa.

Figura 6.1: Participação do agronegócio na composição do PIB do Brasil, em \%. 
Esse fato deve-se, provavelmente, a mudanças estruturais ocorridas na economia brasileira desde o início da década de 90 . Além disso, o período é marcado pela instabilidade econômica, pelo processo inflacionário e pelas tentativas de articulação da economia brasileira com a economia mundial.

As alterações ocorridas na constituição do agronegócio brasileiro no período 1985/1995 podem ser verificadas pela figura 6.2. Essa figura apresenta o agronegócio dividido em 3 agregados: agregado I ou montante do agronegócio; agregado II ou produção agropecuária; e agregado III ou jusante do agronegócio; sendo que esse último agregado pode ser dividido em produção agroindustrial (PAI) e distribuição final (DIF).

Observando-se a figura 6.2 percebe-se uma diminuição da parcela do agregado III em favor dos agregados I e II, principalmente desse último. A parcela do agregado III era $57,7 \%$ em 1985, aumentou para 60,9\% em 1990 e diminuiu para 52,9\% em 1995; para o agregado I, essas parcelas eram, respectivamente, 16,5\%, 15,7\% e $17,6 \%$; e para o agregado II, 25,8\%, 23,4\% e 29,5\%. Acompanhando a diminuição do agregado III, seus componentes, PAI e DIF, também reduzem sua participação no valor total dos bens e serviços produzidos no país.

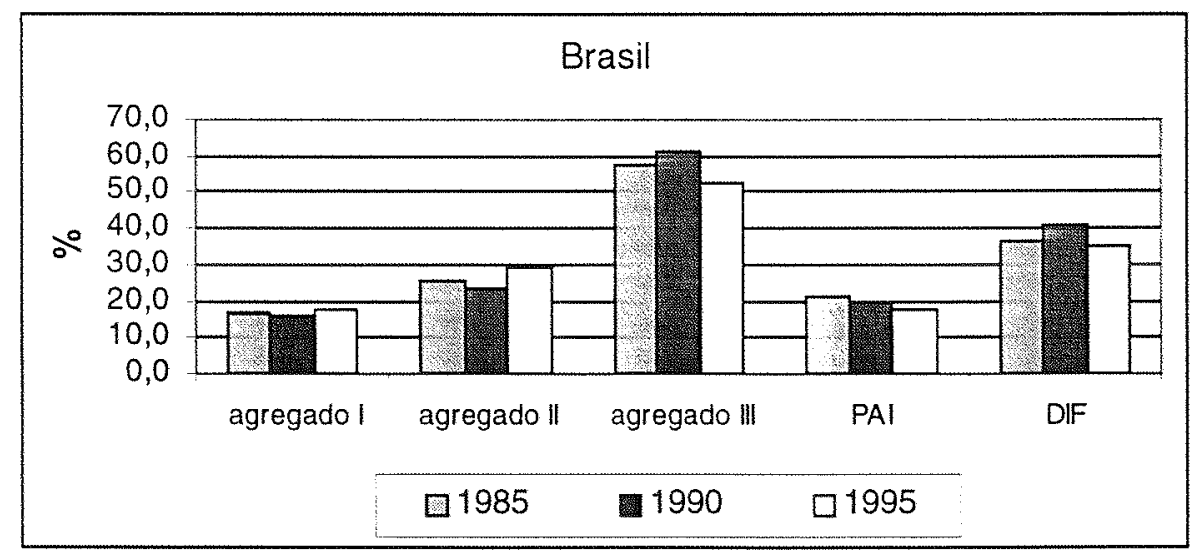

Fonte: Dados da pesquisa.

Figura 6.2: Constituição do agronegócio do Brasil, segundo os seus agregados, em \%, (Obs.: PAI - Produção Agroindustrial, DIF - Distribuição Final). 
A configuração do agronegócio brasileiro para o período da análise , nos parâmetros de Malassis (1969), é de uma economia alimentar industrializada, sendo que o agregado II ou produção agropecuária situou-se entre 1/3 e 1/4 de participação no valor total gerado pelo agronegócio do país.

Deve-se salientar que, apesar das alterações, todos os segmentos do agronegócio apresentaram crescimento absoluto no valor de sua produção. O bom desempenho do setor agropecuário, com aumentos na produção e na produtividade no período 1990/1995, foi o responsável pelo aumento da parcela do agregado II na constituição do agronegócio do país entre 1990 e 1995. Sobre o desempenho recente da agropecuária brasileira e paulista tem-se os trabalhos de Bacha \& Rocha (1999), para o Brasil; e Parré \& Araújo (1997) para São Paulo.

\subsection{Região Norte:}

O desenvolvimento da região Norte do Brasil caracterizou-se, nas décadas de 70 e 80 , por apresentar taxas de crescimento do produto mais elevadas do que a média nacional, apesar de sua participação na produção brasileira de bens e serviços apresentar uma importância reduzida.

A década de 90 indica que o processo de migração para a região encerrou-se. Com o fim de alguns incentivos do Governo para a agricultura da região ocorre um processo de urbanização acelerada em algumas cidades devido ao excedente migratório, como explica Martine (1995): "Assim, a rápida expansão do garimpo, das atividades madeireiras, do comércio, do setor de serviços de todas as espécies e até do narcotráfico serviu para multiplicar o assentamento urbano...".

Paralelo a este processo de aumento do setor de serviços da região ocorre o crescimento da atividade extrativa mineral e metalúrgica, vinculada, principalmente, ao alumínio do Pará. Este processo levou a uma diminuição da parcela do agronegócio na constituição do produto regional. Como pode ser observado na figura 6.3. 
A análise da constituição do agronegócio da região Norte no período 1985/1995 indica um aumento da participação do jusante e da produção agropecuária contra uma diminuição da parcela do montante (figura 6.4). Entretanto, comparando os dados para 1985 e 1990, percebe-se um aumento do agregado I e uma diminuição do agregado II, para, no período seguinte (1990/1995), ocorrer uma inversão nesse comportamento. Ou seja, entre 1990 e 1995 pode-se supor que houve um ganho tecnológico na agropecuária da região Norte pois, utilizando-se de menos insumos, o valor de sua produção aumentou. Entretanto, como a atividade de extrativismo é importante na região, não há condições de afirmar com certeza, baseando-se apenas nos resultados disponíveis, que esse ganho tecnológico realmente ocorreu.

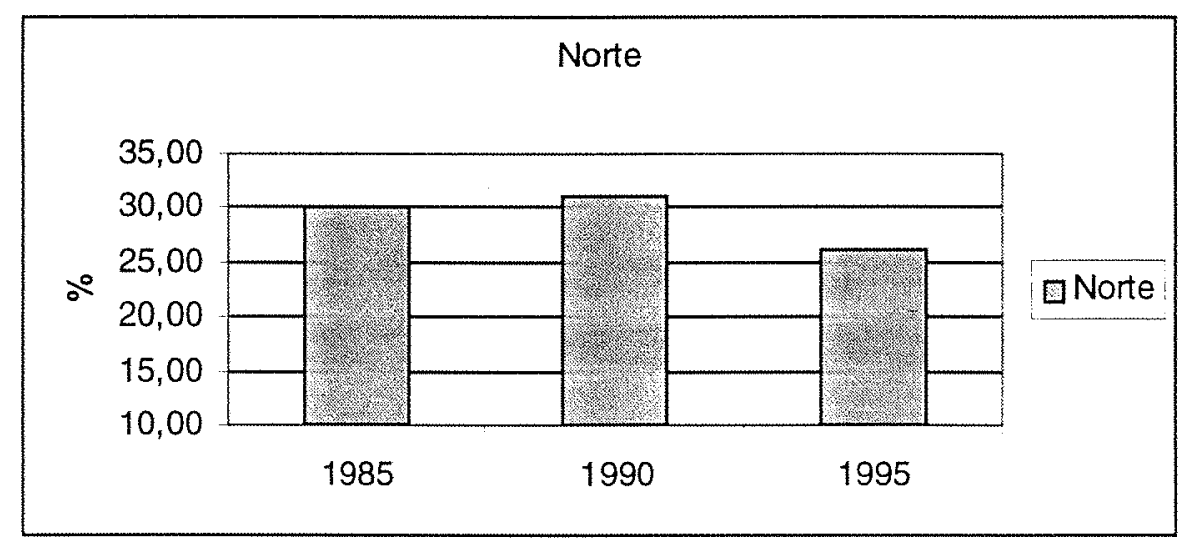

Fonte: Dados da pesquisa.

Figura 6.3: Participação do agronegócio na composição do PIB da região Norte, em \%.

A distribuição do agronegócio da região Norte entre seus agregados, na concepção de Malassis (1969), classifica a economia da região como pré-industrial pois, o agregado II participa com 40,1\% e o agregado III participa com 45,5\% do agronegócio para 1995. Sendo que as perspectivas de alterações nessa participação mostraram-se insignificantes no período de análise, com a produção rural atingindo uma parcela mínima de 36,2\% em 1990.

A contribuição da região Norte para a formação do agronegócio brasileiro e de seus agregados pode ser observada na figura 6.5 . Percebe-se que a contribuição maior 
ocorre no agregado II e deve-se destacar o crescimento da produção agroindustrial da região em relação ao país. Entretanto, as parcelas dessa região são as menores do Brasil. O resultado final, porém, é um aumento da participação do agronegócio da região Norte na formação do valor total do agronegócio brasileiro.

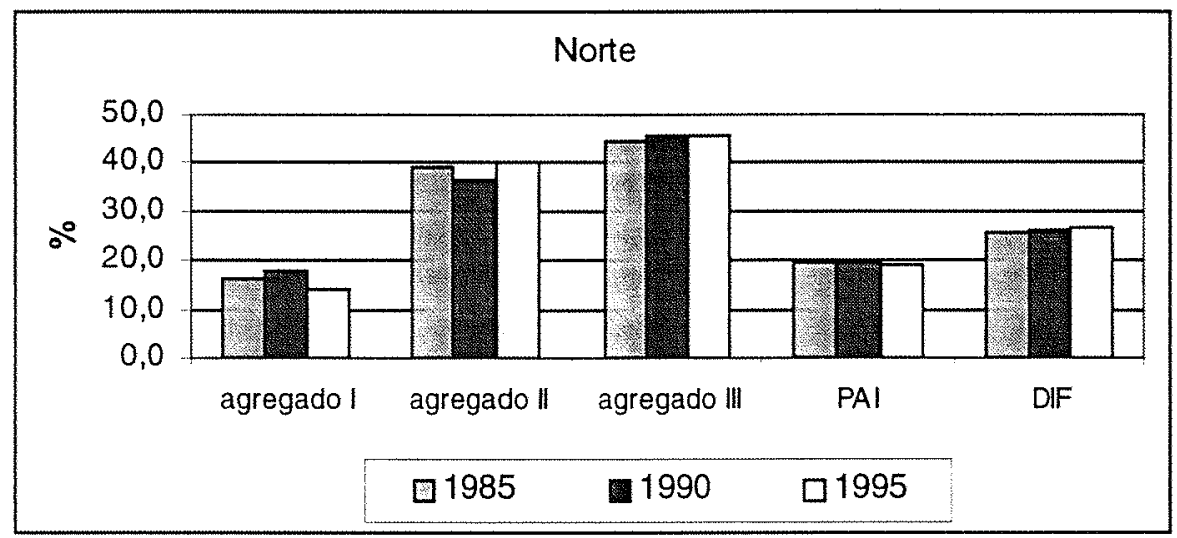

Fonte: Dados da pesquisa.

Figura 6.4: Constituição do agronegócio da região Norte, segundo os seus agregados, em \%. (Obs.: PAI - Produção Agroindustrial, DIF - Distribuição Final)

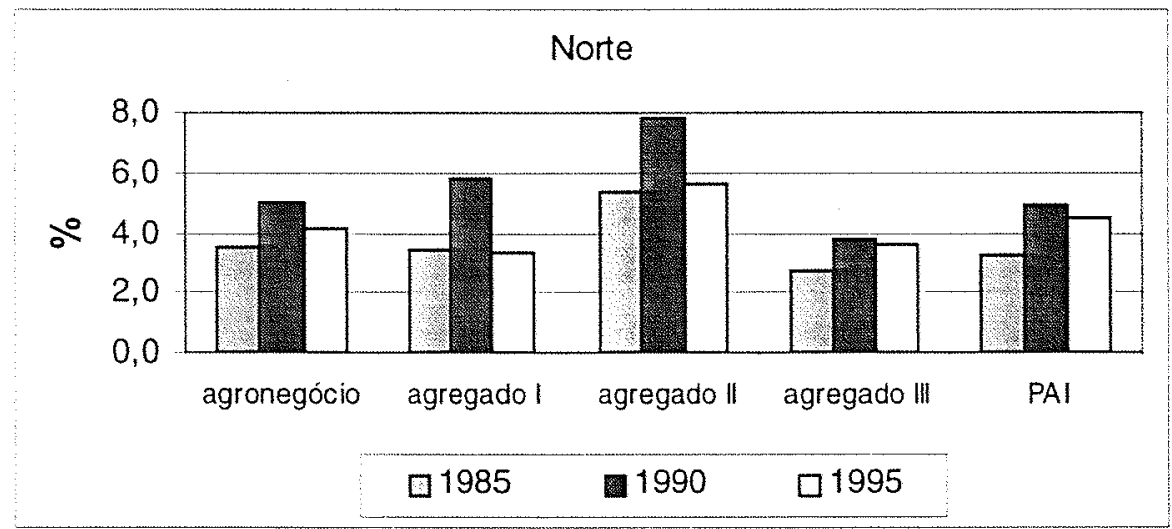

Fonte: Dados da pesquisa.

Figura 6.5: Parcela da região Norte no valor total do agronegócio do Brasil, e de seus agregados, em \%. (Obs.: PAI - Produção Agroindustrial) 


\subsection{Região Nordeste:}

A participação do agronegócio da região Nordeste na composição do PIB regional apresentou uma queda de quase dez pontos percentuais no período 1985/1995 pois, em 1985 essa participação correspondia a 37,8\% e em 1995 foi de $28,3 \%$, como pode ser observado pela figura 6.6.

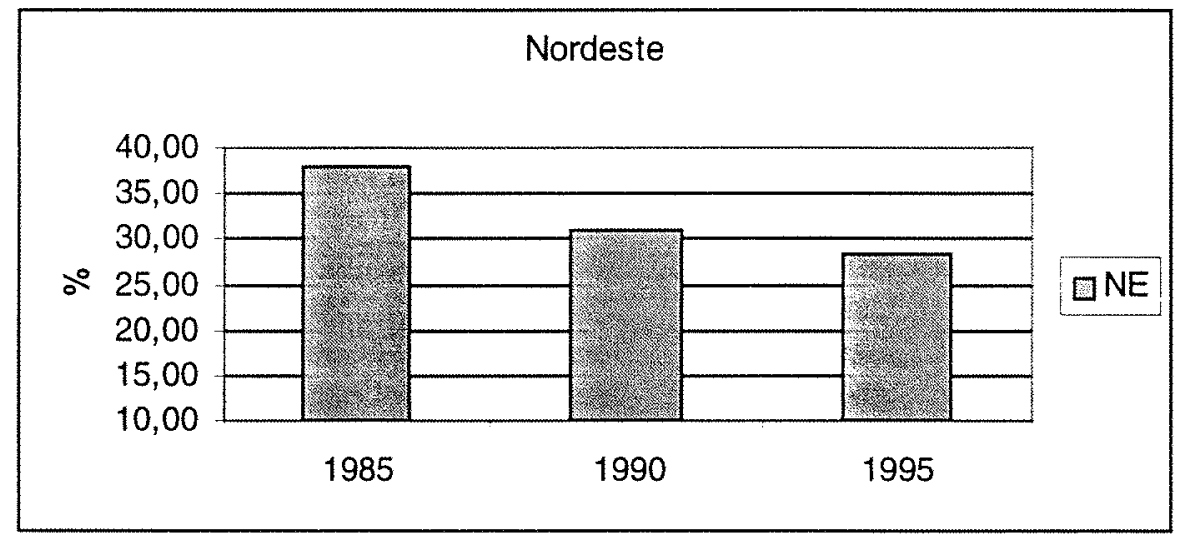

Fonte: Dados da pesquisa.

Figura 6.6: Participação do agronegócio na composição do PIB da região Nordeste, em $\%$.

As transformações ocorridas na economia Nordestina nas décadas de 70 e 80 geraram essa diminuição da parcela do agronegócio no PIB da região, como explica Guimarães Neto (1995): "No Nordeste, ocorreu um avanço da indústria de bens intermediários em detrimento da posição relativa que o segmento produtor de bens de consumo não-duráveis tradicionalmente teve na indústria de transformação regional, sobretudo os setores alimentício e têxtil."

Essa diminuição relativa do setor alimentício na economia do Nordeste pode ser confirmada pela figura 6.7; esse setor, que representava $18,5 \%$ do agronegócio da região em 1985, teve sua parcela diminuída para 14,9\% em 1990 e para 14,5\% em 1995 . O reflexo dessa alteração foi uma diminuição na parcela do agregado III, porém com menor intensidade pois o componente distribuição final aumentou no período 
compensando a diminuição relativa da produção agroindustrial. Entretanto, deve ficar claro que essa análise refere-se à região de maneira agregada, pois a literatura destaca a evolução e modernização de complexos agro-industriais em algumas áreas do Nordeste e a própria modernização de algumas unidades do setor têxtil (Araújo, 1994).

Percebe-se, também, um certo aumento da parcela da produção agropecuária entre 1990 e 1995 e uma diminuição da parcela do setor de insumos para a agricultura (agregado I). Entretanto, comparando-se com as outras regiões do país, pode-se dizer que o agronegócio da região Nordeste foi o que menos sofreu alterações em sua composição no período 1985/1995.

A distribuição do agronegócio da região Nordeste entre seus agregados, nos parâmetros de Malassis (1969), classifica a região como tendo uma economia alimentar em vias de industrialização, ou seja, deixou de ser uma economia pré-industrial, porém ainda não atingiu o nível estrutural de uma economia industrial.

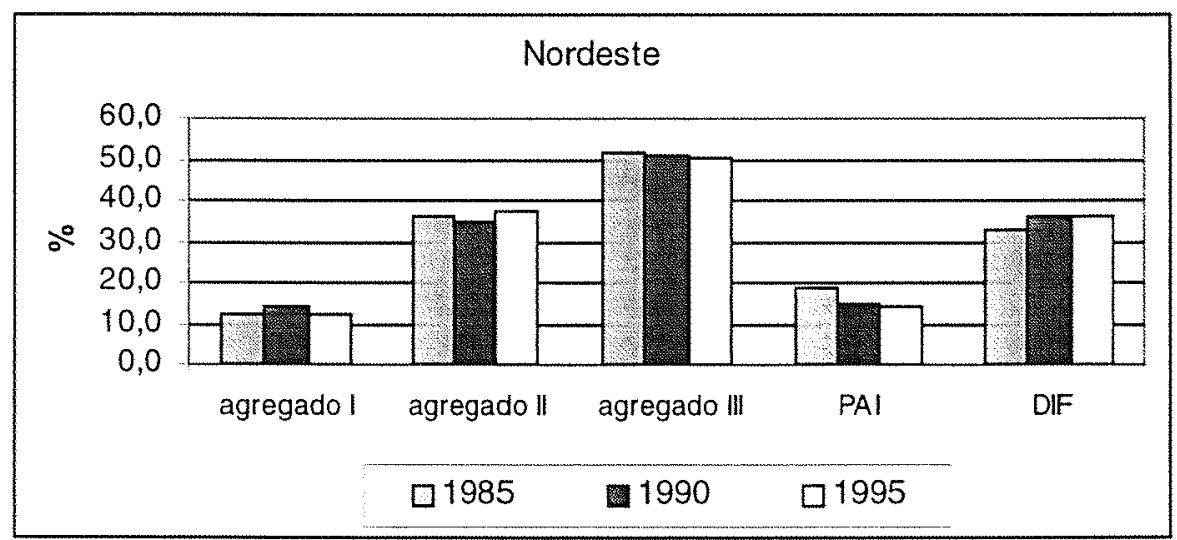

Fonte: Dados da pesquisa.

Figura 6.7: Constituição do agronegócio da região Nordeste, segundo os seus agregados, em \%. (Obs.: PAI - Produção Agroindustrial, DIF - Distribuição Final)

Da mesma forma que diminuiu a importância do agronegócio dentro da região Nordeste, também diminuiu a importância relativa do agronegócio nordestino em relação ao Brasil. Em 1985 a parcela do Nordeste era de 14,8\%, passando para 15,4\% em 1990 e 13,6\% em 1995. O mesmo comportamento ocorreu nos agregados I e II e na 
produção agroindustrial nordestina. Apenas o setor jusante manteve sua parcela em relação ao Brasil no período de análise.

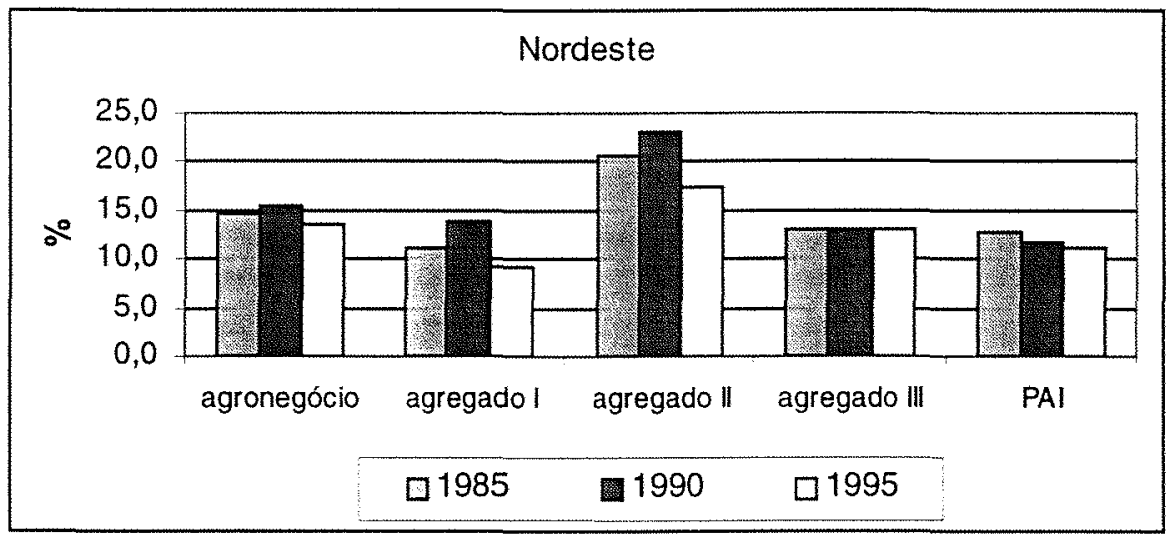

Fonte: Dados da pesquisa.

Figura 6.8: Parcela da região Nordeste no valor total do agronegócio do Brasil, e de seus agregados, em \%. (Obs.: PAI - Produção Agroindustrial)

\subsection{Região Centro-Oeste:}

Quando analisar a economia da região Centro-Oeste deve-se considerar uma peculiaridade importante que é o fato do setor de serviços concentrar mais de $2 / 3$ do produto interno bruto da região, em virtude da grande importância desse setor na economia da capital federal Brasília, como foi demonstrado no capítulo 2 dessa tese. Portanto, a sensibilidade dos setores primário e secundário a alterações no setor terciário é muito maior nessa região do país.

Esse é um dos fatores que levou à grande diminuição da parcela do agronegócio no PIB da região Centro-Oeste entre 1985 e 1990 como pode ser observado na figura 6.9. Nesse mesmo período o PIB dos serviços aumentou sua participação de 67,1\% em 1985 para 70,3\% em 1990, dados da tabela 2.2 (capítulo 2). Entretanto, o dinamismo da agropecuária da região faz com que no período 1990/1995 essa tendência mude de direção, ocasionando um aumento na participação do agronegócio na economia 
regional de quase dois pontos percentuais. A parcela da agropecuária no PIB da região foi de $14,7 \%$ em 1990 para $17,7 \%$ em 1995 (tabela 2.2).

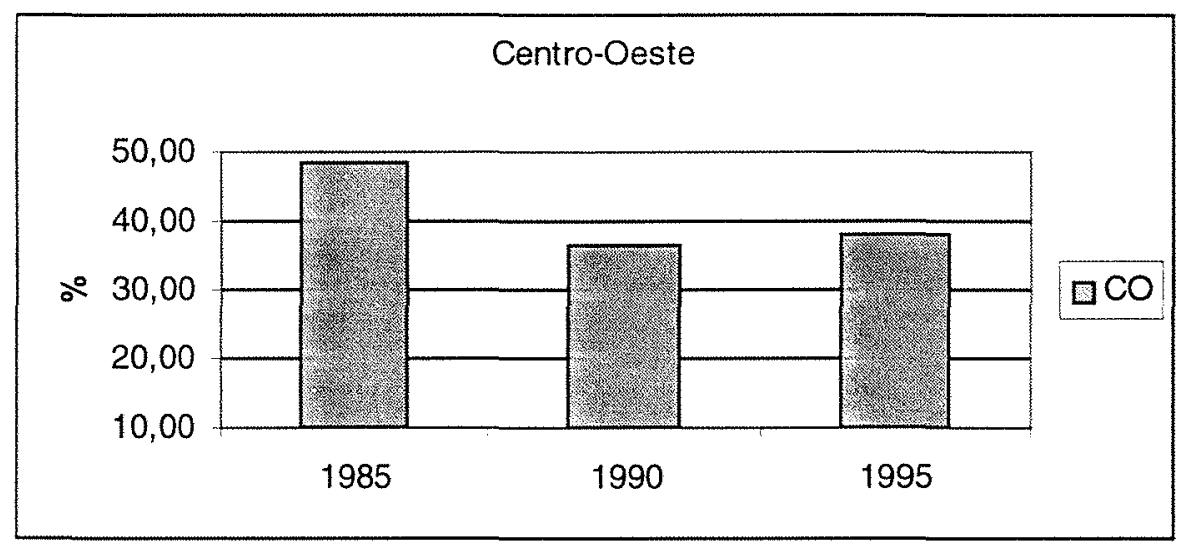

Fonte: Dados da pesquisa.

Figura 6.9: Participação do agronegócio na composição do PIB da região Centro-Oeste, em \%.

A principal característica da constituição do agronegócio da região CentroOeste é a pequena participação relativa do agregado III em sua composição, bem como a reduzida presença da agroindústria na formação do complexo agroindustrial da região, participando com menos de $10 \%$ do mesmo, a menor participação entre todas as regiões do país.

Por outro lado, deve-se destacar a participação do agregado I, atingindo 28,3\% do agronegócio regional em 1995 (a maior do país); e da produção agropecuária, com uma parcela de 39,4\% do agronegócio para 1995. Essas características indicam que o agronegócio da região Centro-Oeste é um grande consumidor de insumos para a agricultura e que não agrega valor à sua produção agropecuária, comparado com as demais regiões brasileiras.

A composição do agronegócio da região Centro-Oeste, na classificação de Malassis (1969), classifica a região como tendo uma economia alimentar pré-industrial. A principal razão é a baixa parcela referente ao agregado III ou jusante do agronegócio, que atingiu uma participação máxima de 42,3\% em 1990, caindo para 32,3\% em 1995. 
Nesses termos, existe a necessidade da região passar a processar seus produtos primários, ao invés de produzi-los e enviá-los para o processamento em outras regiões do país, para que a região melhore na classificação de Malassis.

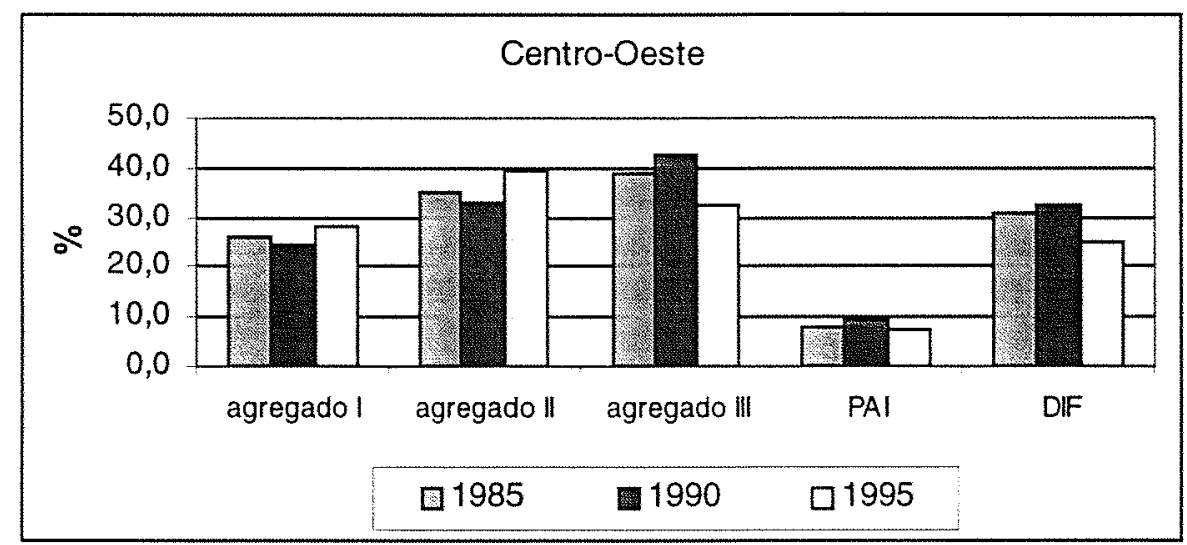

Fonte: Dados da pesquisa.

Figura 6.10: Constituição do agronegócio da região Centro-Oeste, segundo os seus agregados, em \%. (Obs.: PAI - Produção Agroindustrial, DIF - Distribuição Final)

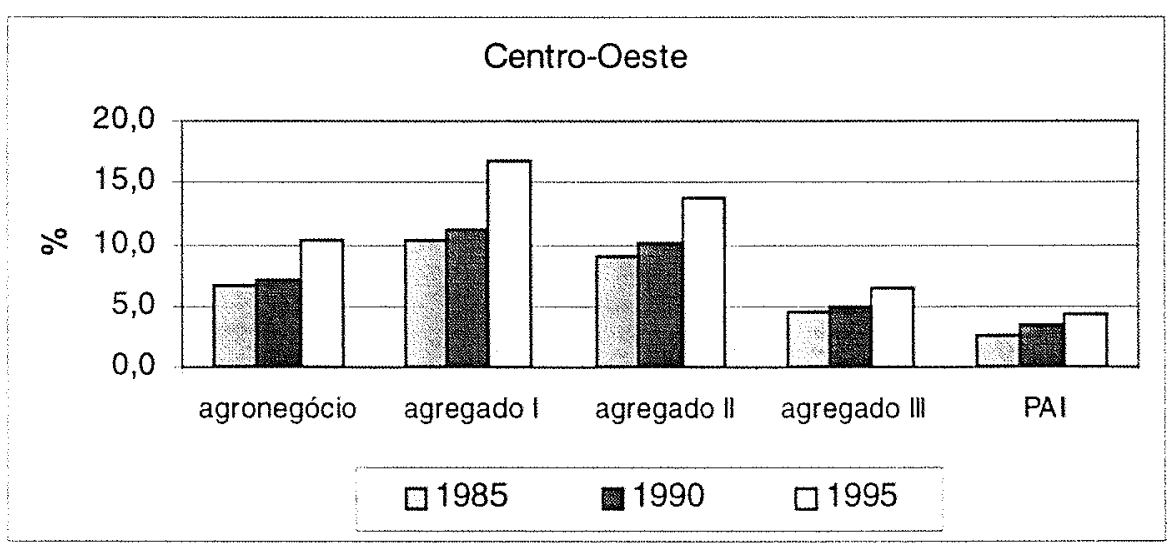

Fonte: Dados da pesquisa.

Figura 6.11: Parcela da região Centro-Oeste no valor total do agronegócio do Brasil, e de seus agregados, em \%. (Obs.: PAI - Produção Agroindustrial)

A participação da região Centro-Oeste na composição do agronegócio brasileiro tem crescido durante todo o período da análise, sendo que esse aumento também é observado para os agregados e seus componentes (figura 6.11). No total, a parcela da região aumentou de 6,6\% em 1985 para 10,4\% em 1995. 
A região Centro-Oeste assumiu com esses aumentos uma posição de importância no complexo agroindustrial brasileiro, principalmente como consumidora de insumos para a agropecuária e na produção agropecuária propriamente dita. Entretanto, sua participação no agregado III é relativamente baixa e sua parcela na produção agroindustrial brasileira é a menor do país.

\subsection{Região Sudeste:}

O dinamismo da economia da região Sudeste, na qual localiza-se uma estrutura produtiva que abrange quase todos os segmentos produtivos estratégicos da economia brasileira, faz com que essa região assuma posição de liderança na produção de bens e serviços no país. O reflexo dessa diversidade da estrutura produtiva sobre o agronegócio regional é torná-lo cada vez menos importante ao longo do período que vai de 1985 e 1995, como vê-se pela figura 6.12. Junte-se a esse aspecto o fato do setor de serviços ter aumentado sua participação no PIB da região de 45,4\% em 1985 para 58,8\% em 1995, dados da tabela 2.2 .

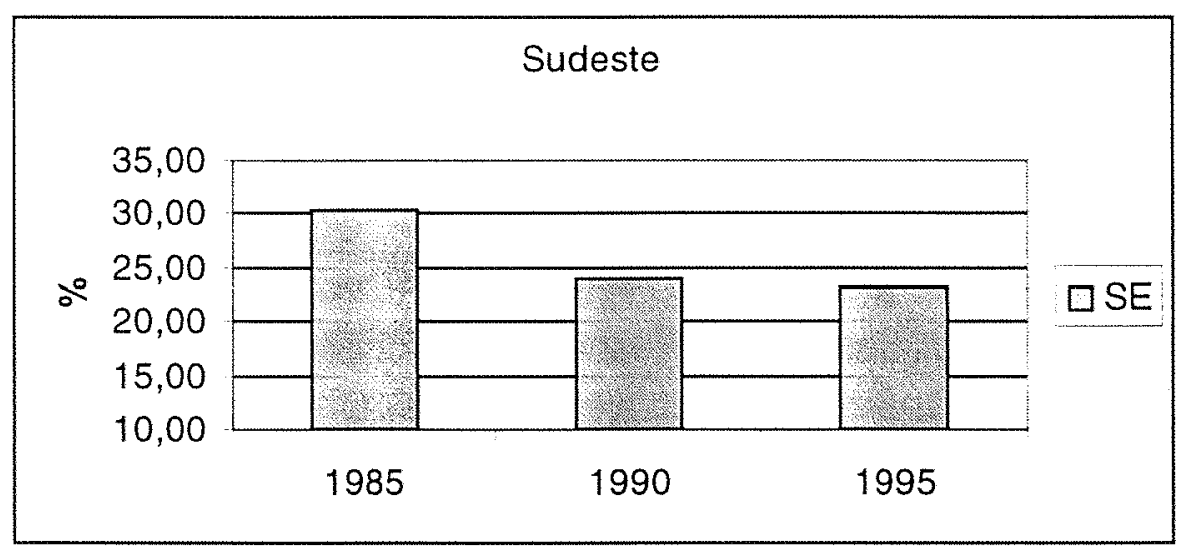

Fonte: Dados da pesquisa.

Figura 6.12: Participação do agronegócio na composição do PIB da região Sudeste, em \%. 
A análise da constituição do agronegócio da região Sudeste mostra todo o poder de agregação de valor característico dos sistemas produtivos desenvolvidos. Do valor total produzido pelo complexo agroindustrial da região em 1995, 15,3\% ficou com o segmento produtor de insumos (agregado I), 23,3\% foi para a produção agropecuária, ou seja, ficou com os agricultores; e $61,3 \%$ foi absorvido pelo segmento de processamento e distribuição final (agregado III), como pode ser observado analisandose a figura 6.13 .

Ao longo do período 1985/1995, nota-se que o agregado I manteve sua participação ao redor de $15,0 \%$, enquanto o agregado II diminuiu sua parcela em 1990 para apresentar um aumento de 5,0\% entre 1990 e 1995 . Movimento inverso ocorreu com o agregado III perdendo $6,0 \%$ de participação no mesmo período.

O agronegócio da região Sudeste apresenta uma configuração para o período da análise , nos parâmetros de Malassis (1969), com características de uma economia alimentar industrializada, sendo que o agregado II ou produção agropecuária participa com menos de $1 / 4$ no valor total gerado pelo agronegócio da região.

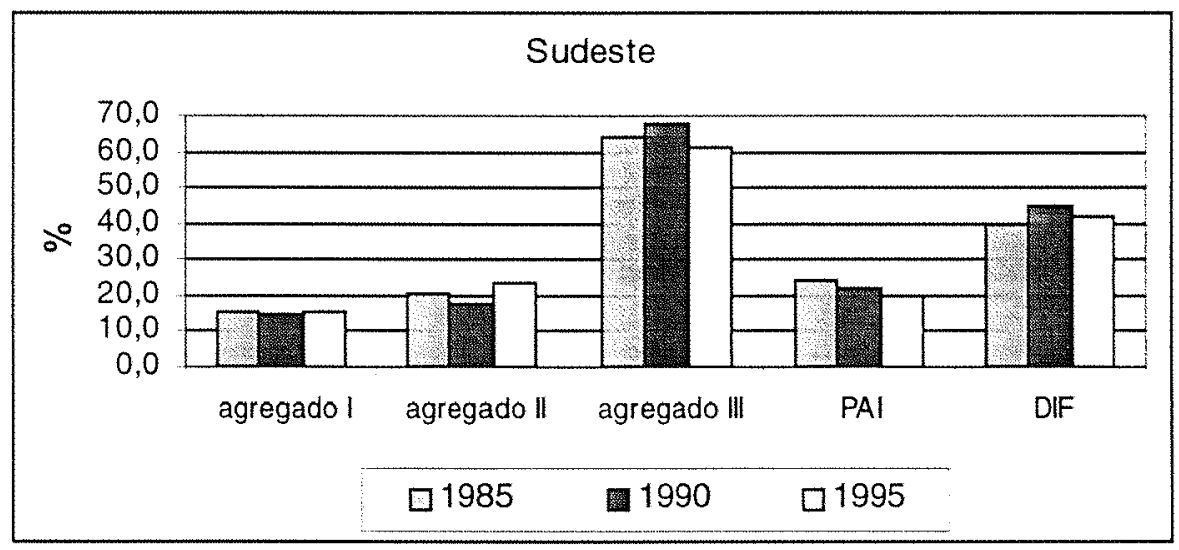

Fonte: Dados da pesquisa.

Figura 6.13: Constituição do agronegócio da região Sudeste, segundo os seus agregados, em \%. (Obs.: PAI - Produção Agroindustrial, DIF - Distribuição Final)

A figura 6.14 permite que se chegue à conclusão que está ocorrendo uma desconcentração do agronegócio brasileiro. Ela mostra uma diminuição da parcela da 
região Sudeste no valor total do agronegócio e, também, em todos os agregados que o compõem. Apesar da região continuar mantendo posição de liderança em todos os agregados e, consequentemente, no agronegócio.

Essa tendência reflete um processo maior de desconcentração regional da economia brasileira; o qual foi descrito no capítulo 2 dessa tese. Os fatores explicativos para a ocorrência desse processo de desconcentração na economia do país são múltiplos e complexos. Especificamente relacionado ao agronegócio, seria um melhor aproveitamento e incorporação de fontes de recursos naturais, possibilitado pela criação de infra-estrutura de transporte e comunicação, principalmente nas regiões Centro-Oeste e Sul, principais beneficiárias do processo de desconcentração do agronegócio brasileiro.

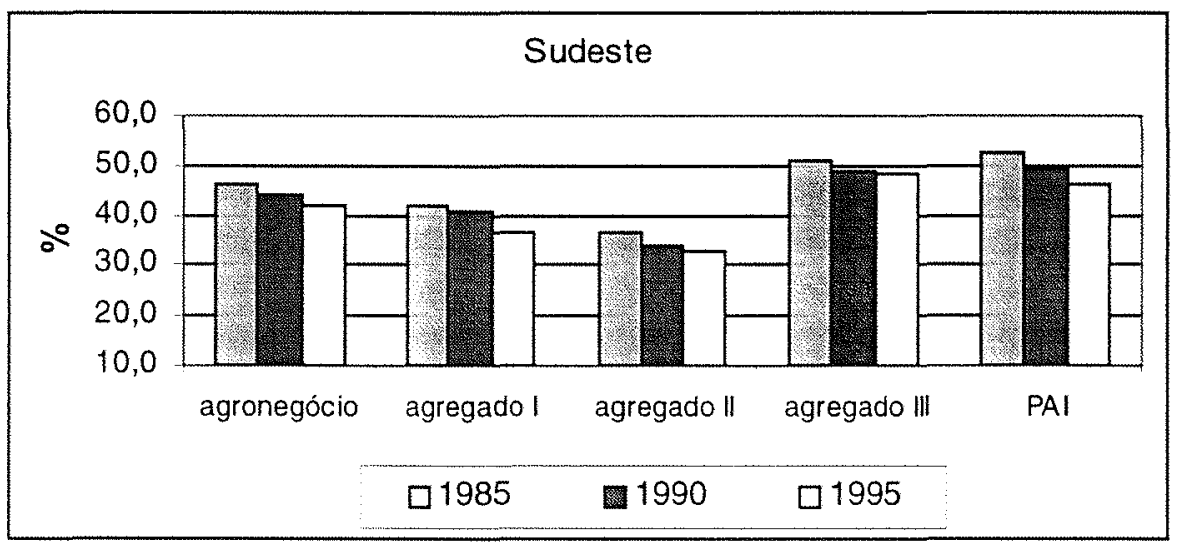

Fonte: Dados da pesquisa.

Figura 6.14: Parcela da região Sudeste no valor total do agronegócio do Brasil, e de seus agregados, em \%. (Obs.: PAI - Produção Agroindustrial)

\subsection{Região Sul:}

A principal característica do agronegócio da região Sul é sua elevada importância dentro da economia da região, como pode ser observado na figura 6.15. Em 1985 o agronegócio correspondia a 67,2\% do PIB da região Sul; em 1990 essa parcela diminuiu para 53,7\%; e em 1995 houve outra pequena queda chegando a 52,5\%. 
A revisão feita sobre a economia da região, apresentada no capítulo 2 , mostra a importância dos segmentos ligados ao agronegócio para a produção de bens e serviços da região. Com destaque para as agroindústrias ligadas ao complexo da soja (óleo, farelo, rações, etc.) no Paraná e Rio Grande do Sul, e as ligadas ao processamento de carnes suínas e de aves, em Santa Catarina. Além do importante papel das cooperativas, que se espalham pelos três estados, apoiando a comercialização agrícola e prestando serviços aos produtores.

Deve-se destacar, também, que as atividades industriais da região, no período analisado, são associadas a produção agrícola como o pólo de couro e calçados; a indústria de bens de capital (máquinas, equipamentos e implementos agrícolas); a indústria de bens de consumo não-duráveis (ligadas à produção de carnes e grãos); e o segmento associado à indústria da madeira.

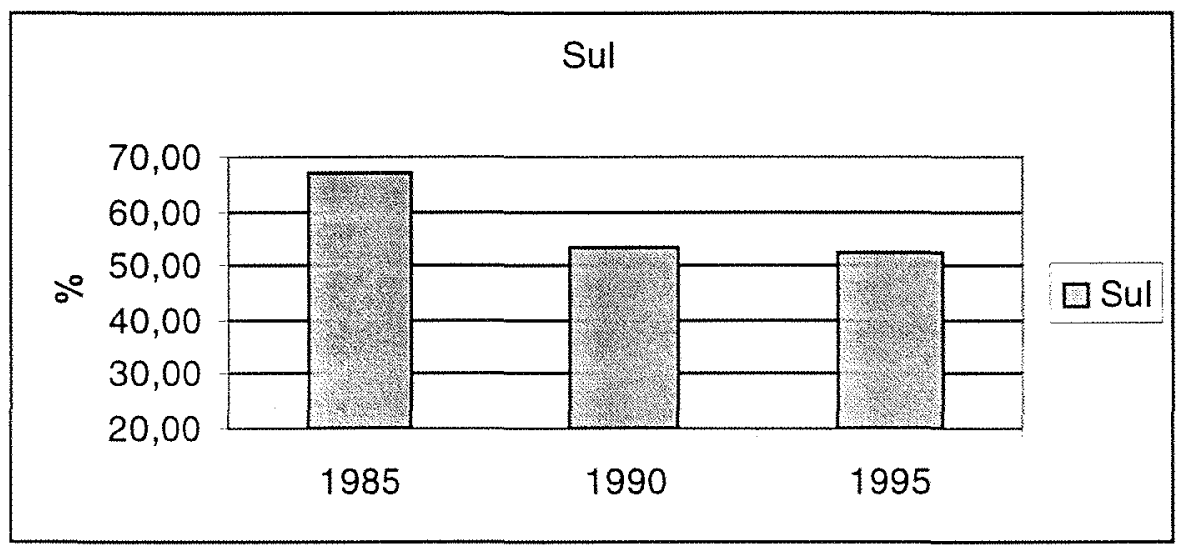

Fonte: Dados da pesquisa.

Figura 6.15: Participação do agronegócio na composição do PIB da região Sul, em \%.

Com relação à grande queda na parcela do agronegócio no PIB da região ocorrida entre 1985 e 1990, deve-se lembrar que a mesma ocorreu para todas as outras regiōes do país; a queda na participação no Centro-Oeste, por exemplo, foi, de $48,6 \%$ para 36,6\% para o mesmo período. Analisando-se a tabela 2.2 (capítulo 2) vemos que entre 1985 e 1990 ocorreu uma queda na participação da agropecuária e um grande aumento na participação dos serviços na formação do PIB da região. 
A constituição do agronegócio da região Sul pode ser observada na figura 6.16. Para o ano de 1995 a configuração indica uma parcela de 20,1\% para o agregado I, $29,6 \%$ para o agregado II e 50,2\% para o agregado III. Uma configuração diferente da observada em 1990 que indicava, respectivamente, 16,0\%,20,6\% e 63,4\%. O fato é que em 1995 a agricultura aumentou o valor de sua produção, através, possivelmente, de uma elevação na produção e na produtividade; consumindo, assim, mais insumos; o que levou a um aumento da participação do agregado I.

Segundo a classificação de Malassis (1969), a composição do agronegócio da região Sul a classifica como uma economia alimentar industrializada, com o segmento de produção agropecuária participando com menos de $1 / 3$ do valor total da produção do agronegócio regional.

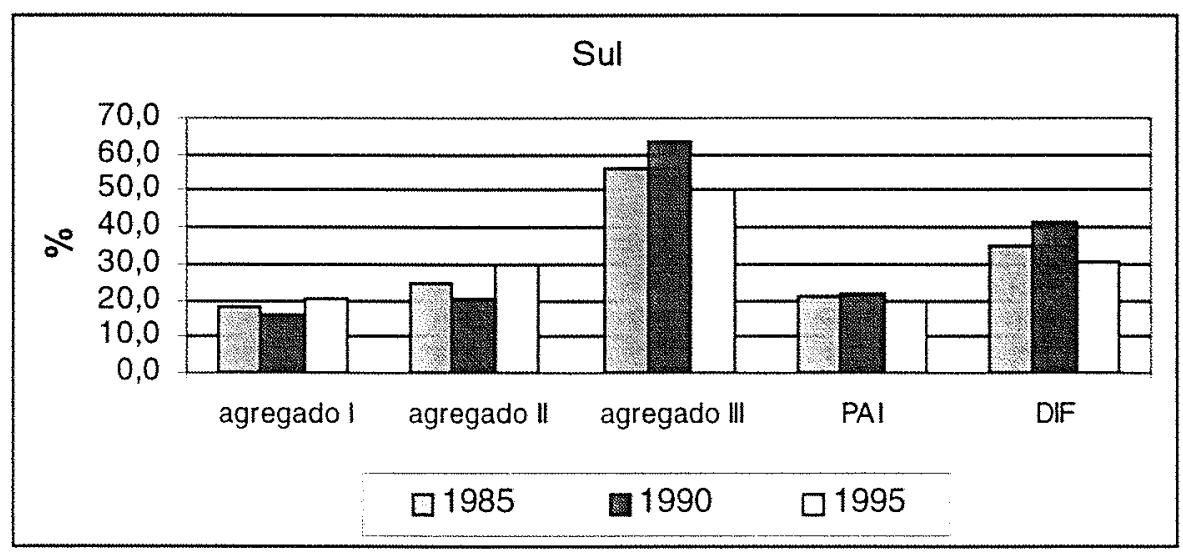

Fonte: Dados da pesquisa.

Figura 6.16: Constituição do agronegócio da região Sul, segundo os seus agregados, em \%. (Obs.: PAI - Produção Agroindustrial, DIF - Distribuição Final)

A parcela do agronegócio brasileiro que é apropriada pela região Sul aumentou no período de análise, como pode ser observado na figura 6.17. O ganho no total do agronegócio foi relativamente baixo, 29,2\% em 1985 para 30,0\% em 1995. Entretanto, alguns dos segmentos alcançaram posição de destaque, como o agregado I que possui uma parcela de $34,2 \%$ do total do país; e a produção agroindustrial da região Sul, que passa a concentrar 33,7\% do total nacional para esse segmento no ano de 1995. 
A região Sul, portanto, passa a ser uma das beneficiárias do processo de desconcentração do agronegócio brasileiro, graças ao crescimento relativo de sua produção agropecuária, a qual passou a consumir mais insumos; e graças à capacidade de sua agroindústria em agregar valor aos produtos agropecuários da região.

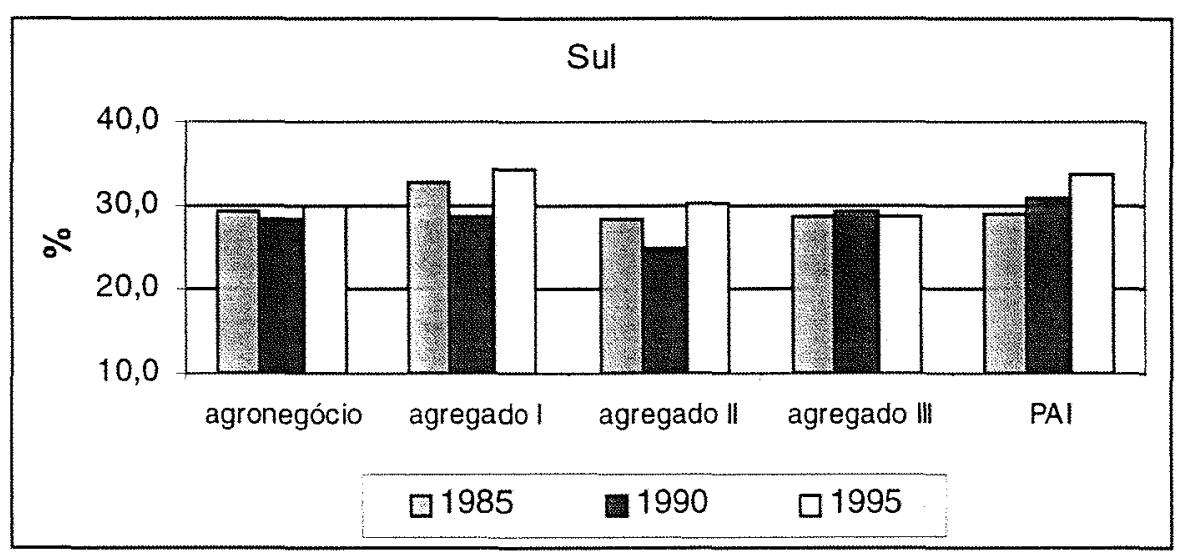

Fonte: Dados da pesquisa.

Figura 6.17: Parcela da região Sul no valor total do agronegócio do Brasil, e de seus agregados, em \%. (Obs.: PAI - Produção Agroindustrial)

\subsection{Considerações finais}

Nesse capítulo, discutiu-se com mais detalhes a constituição do agronegócio das regiões brasileiras. Procurou-se identificar o nível de importância de cada segmento no processo de agregação de valor realizado pelo complexo agroindustrial ou agronegócio nas regiões.

Para um melhor "fechamento" da discussão, será realizada uma análise comparativa dos principais resultados obtidos para o agronegócio de cada região. Nesse sentido, as informações apresentadas no capítulo possibilitam caracterizar a estrutura interna do agronegócio das regiões e comparar seu comportamento no período de 1985 a 1995. As principais observações são: 
a) Percebe-se uma grande heterogeneidade estrutural no agronegócio brasileiro, variando de região para região;

b) Convivem níveis diferentes de desenvolvimento inter e intrarregional no agronegócio do país; principalmente quando compara-se o segmento de processamento, armazenamento e distribuição final de produtos agropecuários (jusante do agronegócio).

A figura 6.18 apresenta a parcela do segmento da montante na formação do valor total a custos de fatores do agronegócio do Brasil e de suas regiões no período de 1985 a 1995. Para a região Centro-Oeste este segmento é o mais representativo para os três períodos da análise, com uma participação de pouco mais de $1 / 4$ na composição do agronegócio da região.

Tomando como base o ano de 1995, tem-se as seguintes parcelas, em ordem decrescente: região Centro-Oeste, 28,3\%; região Sul, 20,1\%; região Sudeste, 15,3\%; região Norte, $14,3 \%$; e região Nordeste $12,1 \%$. Para o Brasil essa participação ficou em $17,6 \%$ para 1995. Percebe-se, também, que não existe uma tendência no comportamento dessa parcela, para algumas regiões ocorreu um aumento durante o período 1985/1990, enquanto para outras ocorreu uma diminuição.

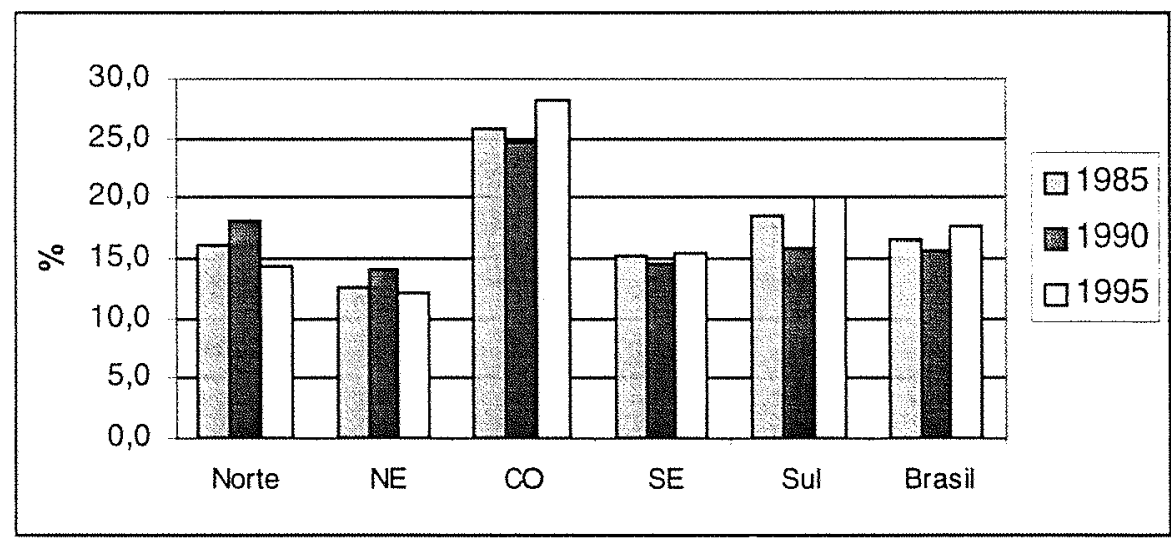

Fonte: Dados da pesquisa.

Figura 6.18: Participação do agregado I (montante) no valor total do agronegócio do Brasil e das regiões, em \%. 
O valor ideal para essa participação é bastante relativo. Sabe-se que a diferença entre a participação do agregado I e a participação do agregado II serve como um indicador da capacidade de agregar valor pelo setor agropecuário do agronegócio. Portanto, quanto maior a parcela do agregado I, maior haverá de ser a parcela do agregado II e, consequentemente, menor a parcela do agregado III. Sendo assim, parcelas menores do agregado I seriam mais indicadas para uma economia alimentar industrializada.

A participação da produção agropecuária no processo de agregação de valor pelo agronegócio do Brasil e das regiões é apresentado na figura 6.19. As participações são as seguintes, para os anos de 1990 e 1995, respectivamente: Brasil, 23,4\% e 29,5\%; região Norte, $36,2 \%$ e $40,1 \%$; região Nordeste $35,0 \%$ e 37,5\%; região Centro-Oeste, $33,0 \%$ e $39,4 \%$; região Sudeste, $18,0 \%$ e $23,3 \%$; e região Sul, $20,6 \%$ e $29,6 \%$.

Apesar da alteração ocorrida entre 1990 e 1995, quebrando uma tendência de diminuição da importância da agricultura na composição do agronegócio das regiões que ocorreu entre 1985 e 1990, a diferença entre as regiões é tão significativa que pode-se dividi-las em dois grupos. O primeiro composto pelas regiões Norte, Nordeste e CentroOeste; onde a agropecuária participa com mais de 1/3 no agronegócio; e o segundo formado pelas regiões Sudeste e Sul; onde essa participação fica abaixo de 30,0\%.

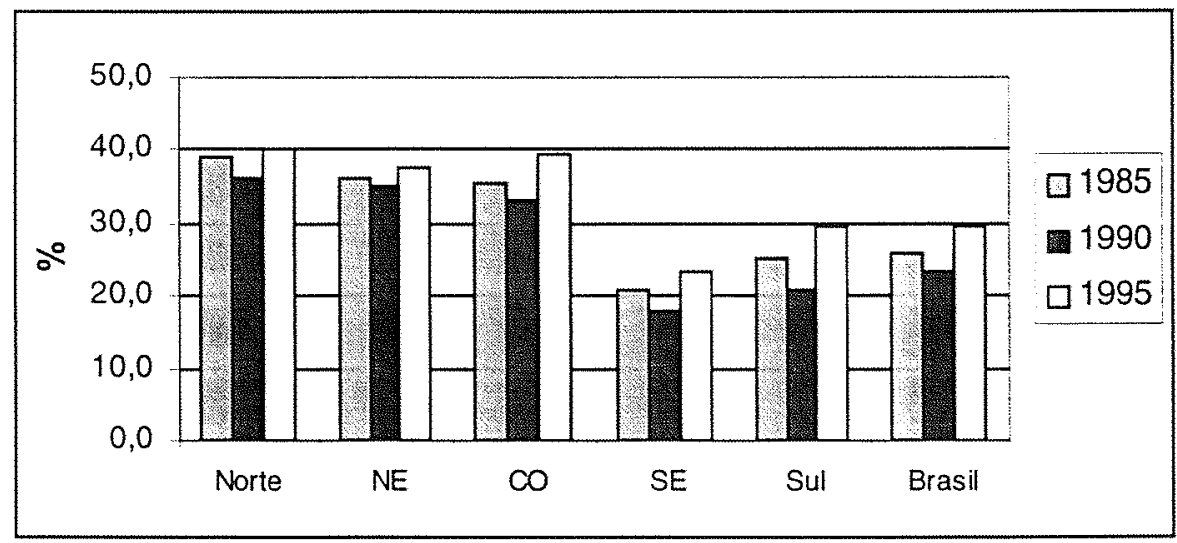

Fonte: Dados da pesquisa.

Figura 6.19: Participação do agregado II (produção agropecuária) no valor total do agronegócio do Brasil e das regiões, em \%. 
A figura 6.20 apresenta a parcela do agregado III ou jusante no valor total do agronegócio do Brasil e das regiões do país. Percebe-se que houve uma inversão nas posições dos grupos comentados anteriormente, principalmente se for considerado o ano de 1990. As participações desse agregado são as seguintes, para os anos de 1990 e 1995, respectivamente: Brasil, $60,9 \%$ e 52,8\%; região Norte, 45,7\% e 45,5\%; região Nordeste $51,0 \%$ e $50,3 \%$; região Centro-Oeste, $42,3 \%$ e $32,3 \%$; região Sudeste, $67,5 \%$ e $61,3 \%$; e região Sul, $63,4 \%$ e $50,2 \%$.

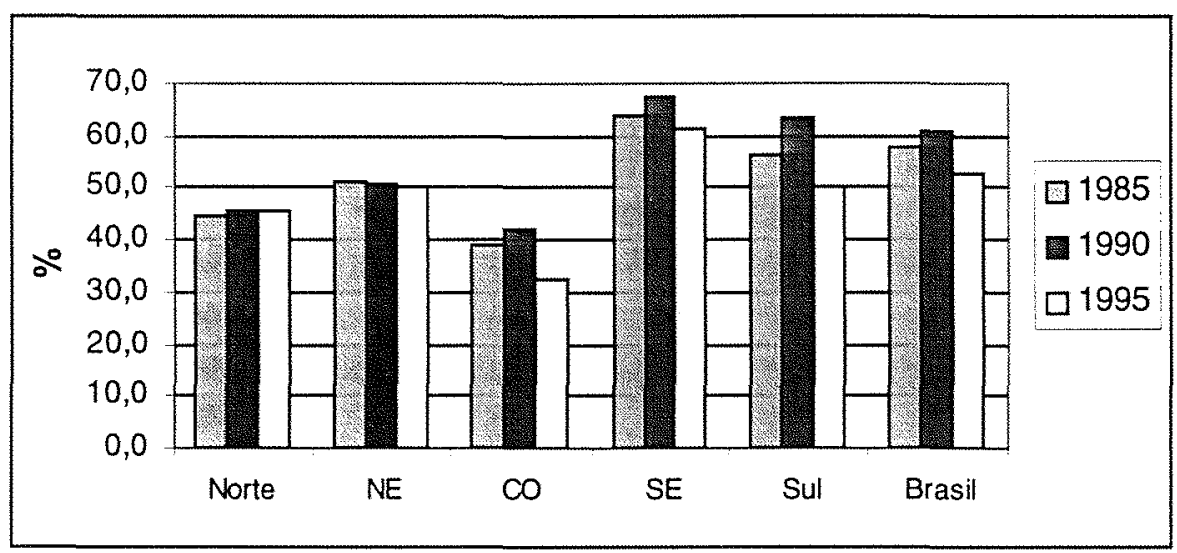

Fonte: Dados da pesquisa.

Figura 6.20: Participação do agregado III (jusante) no valor total do agronegócio do Brasil e das regiões, em \%.

A região Sudeste destaca-se nesse segmento, tanto na agroindústria quanto na distribuição final dos produtos. A importância da agroindústria na constituição do agronegócio das regiões pode ser observada na figura 6.21 . O destaque negativo é a região Centro-Oeste que possui um agregado III e uma agroindústria de pouca importância na formação do agronegócio. A região Norte apresenta uma característica interessante, uma baixa parcela do agregado III e uma parcela da agroindústria relativamente elevada; ou seja, o segmento de distribuição final da região participa pouco da composição do agronegócio, talvez, devido às grandes distâncias entre os centros consumidores da região. 


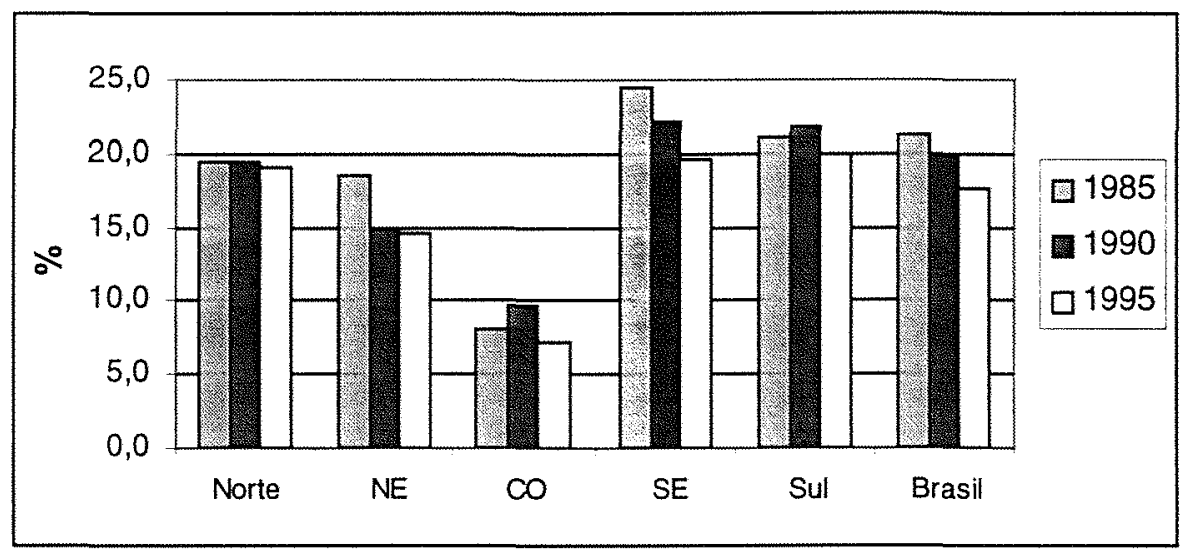

Fonte: Dados da pesquisa.

Figura 6.21: Participação da produção agroindustrial no valor total do agronegócio do Brasil e das regiões, em \%.

Para finalizar, deve-se comparar como as regiões classificaram-se, de acordo com os parâmetros de Malassis (1969). Utilizando-se desse parâmetros, o agronegócio das regiões Sudeste e Sul apresentam uma configuração com características de uma economia alimentar industrializada; já para a região Centro-Oeste e Norte, a classificação seria de uma economia pré-industrial; e a região Nordeste teria uma economia alimentar em vias de industrialização. 


\section{AS TRANSAÇÕES INTERREGIONAIS DO AGRONEGÓCIO BRASILEIRO}

Após analisar o agronegócio de cada região do país, resta saber as relações interregionais que existem entre os mesmos; ou seja, as relações de compra e venda que ocorrem entre as regiões relativas ao agronegócio. A obtenção dessas informações permitirá saber quais os maiores "parceiros econômicos" por vias internas com relação ao agronegócio de cada região. Também será possível determinar qual a importância do mercado internacional para o agronegócio das regiões e os maiores exportadores e importadores do agronegócio nacional.

\subsection{Exportações e importações do agronegócio brasileiro para o exterior.}

Inicialmente, será realizada uma análise comparativa entre as regiões, somente com as transações para o exterior do país, realizadas pelos segmentos do agronegócio das regiões do Brasil, antes, entretanto, é necessário verificar o comportamento das regiões considerando todos os setores da economia.

Nesse sentido, a tabela 7.1 demonstra que todas as regiões do país aumentaram seu comércio com outros países, ou seja, ocorreu um aumento do valor das exportações regionalizadas desde a década de 70. Como explica Guimarães Neto (1995), esse desempenho foi devido aos grandes estímulos fiscais e financeiros oferecidos pelo Governo na década de 70 e, nos anos 80, a crise, a instabilidade da economia e a retração do mercado interno e a necessidade de gerar divisas para o pagamento da dívida 
externa, induziram grande parcela da atividade econômica do país a voltar-se para o exterior. As importações apresentaram grande crescimento entre 1970 e 1980; com uma queda entre 1980 e 1985; voltando a crescer a partir da segunda metade da década de 80.

Dentro dessa perspectiva, a região Norte, através principalmente da venda de minérios e produtos metalúrgicos provenientes do complexo Carajás, aumentou suas exportações de US\$ 87 milhões em 1970, para US\$ 2,4 bilhões em 1995; um crescimento maior que a média nacional. A região Nordeste apresentou um acrescimento menos intenso, porém significativo, principalmente nos Estados da Bahia e do Maranhão; essa região aumentou suas vendas para o exterior de US\$ 407 milhões em 1970 para US\$ 3,0 bilhões em 1990 e US\$ 4,2 bilhões em 1995. A região Centro-Oeste é a que menos participa do comércio exterior do Brasil, porém, também apresentou aumento de suas exportações, principalmente na segunda metade da década de 80 .

Tabela 7.1: Exportações e importações segundo as regiões do Brasil. Em milhões de Dólares correntes, 1970 a 1995.

\begin{tabular}{llrr|rr|rr|rr|rr}
\hline & & \multicolumn{1}{c|}{1970} & \multicolumn{2}{|c|}{1980} & \multicolumn{2}{|c|}{1985} & \multicolumn{2}{|c|}{1990} & \multicolumn{2}{|c}{1995} \\
\hline & & valor & $\%$ & valor & $\%$ & valor & $\%$ & valor & $\%$ & valor & $\%$ \\
\hline Norte & Exp. & 87 & 3,1 & 596 & 3,4 & 539 & 2,3 & 1794 & 5,8 & 2433 & 5,3 \\
& Imp. & 114 & 3,8 & 908 & 3,6 & 594 & 4,1 & 1393 & 6,7 & & \\
NE & Exp. & 407 & 14,6 & 2297 & 13,3 & 2526 & 11,0 & 3030 & 9,7 & 4240 & 9,3 \\
& Imp. & 178 & 5,9 & 1590 & 6,4 & 834 & 5,8 & 1492 & 7,2 & & \\
CO & Exp. & 10 & 0,4 & 53 & 0,3 & 116 & 0,5 & 563 & 1,8 & 987 & 2,2 \\
& Imp. & 4 & 0,1 & 150 & 0,6 & 34 & 0,2 & 171 & 0,8 & & \\
& & & & & & & & & & & \\
SE & Exp. & 1587 & 57,0 & 10169 & 58,7 & 14284 & 62,2 & 18929 & 60,9 & 26635 & 58,3 \\
& Imp. & 2449 & 80,6 & 18438 & 73,9 & 11473 & 80,1 & 15396 & 74,6 & & \\
& & & & & & & & & & & \\
SU & Exp. & 692 & 24,9 & 4200 & 24,3 & 5496 & 23,9 & 6767 & 21,8 & 11401 & 25,0 \\
& Imp. & 292 & 9,6 & 3874 & 15,5 & 1396 & 9,7 & 2196 & 10,6 & & \\
Brasil & Exp. & 2783 & 100,0 & 17315 & 100,0 & 22961 & 100,0 & 31083 & 100,0 & 46506 & \\
& Imp. & 3037 & 100,0 & 24960 & 100,0 & 14331 & 100,0 & 20648 & 100,0 & 49858 & \\
& Dif. & -254 & & -7645 & & 8630 & & 10435 & & -3352 & \\
\hline
\end{tabular}

Fonte: CACEX/IBGE, citado por Guimarães Neto (1995); e Anuário Estatístico do Brasil 1997, para os dados de 1995. Obs.: Do total exportado de 1995, US\$ 811 milhões são não-declarados 
A região Sudeste é a mais integrada ao comércio internacional, com uma parcela de $57,0 \%$ e 58,3\% das exportações do país, para os anos de 1970 e 1995 , respectivamente. A parcela dessa região nas importações do país chegou a 80,0\% em 1970 e 1985. A região Sul manteve-se com 25,0\% das exportações do país.

Vale lembrar, ainda a afirmação de Guimarães Neto (1995) sobre a composição da pauta de exportações do Brasil: "A crescente inserção da economia brasileira na economia internacional vem ocorrendo através da ampliação das exportações de produtos manufaturados em detrimento dos produtos básicos, que em décadas passadas caracterizaram o perfil exportador do país".

A tabela 7.2 apresenta as participações das regiões nas exportações por grandes classes de produtos. Percebe-se que a região Norte e a Sudeste aumentaram suas participações nas exportações de produtos básicos entre 1975 e 1990, mesmo com esses produtos perdendo espaço nas exportações internas dessas regiões, seguindo a tendência ocorrida no país. Outra região que teve sua parcela aumentada foi o Centro-Oeste.

A região Norte aumentou sua parcela nos produtos básicos e semimanufaturados . A região Nordeste, foi a que apresentou maior diminuição em suas participações nas classes de produtos básicos e semi-manufaturados, seguindo a tendência de queda de sua parcela nas exportações brasileiras indicada na tabela 7.1.

Com relação aos produtos manufaturados, as participações apresentaram poucas alterações no período, com uma pequena queda da parcela da região Sudeste.

Tabela 7.2: Distribuição espacial das exportações por classes de produtos. Em percentagem. (base em US $\$ 1,00$ ).

\begin{tabular}{l|r|r|r|r|r|r|r|r|r|r|r|r|r|}
\hline & \multicolumn{4}{|c|}{ básicos } & \multicolumn{4}{|c|}{ Semimanufaturados } & \multicolumn{4}{|c}{ Manufaturados } \\
\hline & 1975 & 1980 & 1985 & 1990 & 1975 & 1980 & 1985 & 1990 & 1975 & 1980 & 1985 & 1990 \\
\hline Norte & 3,6 & 4,5 & 5,2 & 11,1 & 1,8 & 5,2 & 3,2 & 12,5 & 1,3 & 2,3 & 0,9 & 1,1 \\
\hline NE & 25,0 & 20,6 & 13,4 & 8,6 & 28,1 & 21,1 & 18,7 & 17,9 & 7,7 & 6,3 & 8,4 & 8,0 \\
\hline CO & 0,6 & 0,4 & 1,1 & 4,3 & 0,1 & 0,8 & 0,9 & 1,0 & 0,5 & 0,1 & 0,2 & 0,2 \\
\hline SE & 37,3 & 37,8 & 42,0 & 43,1 & 41,3 & 49,9 & 59,0 & 55,7 & 72,9 & 75,1 & 71,7 & 71,8 \\
\hline Sul & 33,4 & 36,7 & 38,3 & 33,0 & 28,7 & 22,9 & 18,2 & 12,9 & 17,6 & 16,1 & 18,7 & 18,9 \\
\hline Brasil & 100 & 100 & 100 & 100 & 100 & 100 & 100 & 100 & 100 & 100 & 100 & 100 \\
\hline
\end{tabular}

Fonte: CACEX, citado por Araújo (1995). Adaptado pelo autor. 
A tabela 7.3 apresenta a distribuição das exportações e das importações do agronegócio brasileiro entre as regiões do país. Os segmentos de produção agropecuária (agregado II) e de produção agroindustrial do agronegócio, e as respectivas exportações e importações regionais estão representadas nessa tabela. A soma de todas as participações representa o total para o Brasil. Por exemplo, a região Norte participa com 1,69\% das importações e 4,96\% das exportações do setor de produção agropecuária do Brasil para o ano de 1985; sendo que a sua participação no valor total da produção do setor é de 5,35\%.

Portanto, essa tabela permite que se tenha uma visão da importância de cada região nas relações de comércio exterior do agronegócio brasileiro, e as alterações que ocorreram entre 1985 e 1995. Com relação à posição relativa das regiões, o que se observa é que os resultados para 1985 e 1995 são semelhantes; sendo que as maiores alteraçōes aconteceram apenas em 1990. Por exemplo, a parcela da região Sudeste no total de exportações do agronegócio diminuiu de 39,8\% em 1985 para 35,4\% em 1990; porém, no ano de 1995 essa participação foi de 39,4\%. De um modo geral, os resultados obtidos para o comportamento das relações internacionais do agronegócio refletem àqueles obtidos para a economia como um todo, que foram apresentados na tabela 7.1; apenas a magnitude das parcelas de cada região são diferentes. Como exemplo, tem-se a parcela da região Sudeste nas exportações que é $58,3 \%$ para a economia como um todo e 39,4\% para os componentes do agronegócio, em 1995.

As importações de insumos pelo setor agropecuário indicaram um aumento da participação da região Centro-Oeste, cuja parcela de 10,7\% em 1985 foi para 16,2\% em 1995, refletindo o aumento da produtividade agrícola da região; a região Sudeste diminuiu sua participação nas importações desse setor, indicando um certo "fechamento" da economia dessa região.

As exportações totais indicam um crescimento da parcela da região Norte e da região Sul, entre 1985 e 1995, contra uma pequena diminuição das parcelas das demais regiões do Brasil. Esse comportamento reflete o dinamismo do agronegócio da região Sul e o crescimento da região Norte. 
Tabela 7.3: Participação das regiões nas exportações e importações para o exterior, (Brasil=100)

\begin{tabular}{|c|c|c|c|c|c|c|}
\hline & \multicolumn{3}{|c|}{ Região Norte (\%) } & \multicolumn{3}{|c|}{ BRASIL (valores) } \\
\hline & 1985 & 1990 & 1995 & 1985 & 1990 & 1995 \\
\hline A - Agregado II & 5,35 & 7,81 & 5,67 & 127971 & 2300430 & 52245662 \\
\hline Importações do exterior & 1,69 & 2,51 & 1,67 & 590 & 27820 & 1002873 \\
\hline exportações para o exterior & 4,96 & 16,41 & 7,97 & 5856 & 57199 & 958129 \\
\hline B - Produção Agroindustrial (PAI) & 3,22 & 4,93 & 4,47 & 105420 & 1957553 & 31337081 \\
\hline Importaçóes do exterior & 1,25 & 2,33 & 2,73 & 5726 & 162241 & 4487335 \\
\hline exportações para o exterior & 1,57 & 9,18 & 5,48 & 13768 & 170829 & 3542968 \\
\hline Total de exportacões $(A+B)$ & 2,58 & 10,99 & 6,01 & 19625 & 228028 & 4501098 \\
\hline & \multicolumn{3}{|c|}{ Região Nordeste (\%) } & & & \\
\hline & 1985 & 1990 & 1995 & & & \\
\hline A - Agregado II & 20,64 & 23,14 & 17,32 & & & \\
\hline Importações do exterior & 10,01 & 11,58 & 8,07 & & & \\
\hline exportações para o exterior & 19,50 & 27,82 & 25,36 & & & \\
\hline B - Produção Agroindustrial (PAI) & 12,82 & 11,57 & 11,14 & & & \\
\hline Importações do exterior & 17,01 & 12,29 & 9,87 & & & \\
\hline exportações para o exterior & 17,24 & 16,88 & 14,38 & & & \\
\hline Total de exportações $(A+B)$ & 17,92 & 19,63 & 16,72 & & & \\
\hline
\end{tabular}

Total de exportações $(A+B)$

A - Agregado II

Importações do exterior

exportações para o exterior

B - Produção Agroindustrial (PAI)

Importações do exterior

exportações para o exterior

Total de exportacões $(A+B)$

Região Centro-Oeste (\%)

$\begin{array}{lll}1985 & 1990 & 1995\end{array}$

$8,95 \quad 10,16 \quad 13,85$

$10,67 \quad 12,64 \quad 16,24$

$18,75 \quad 10,77 \quad 13,97$

$2,50 \quad 3,48 \quad 4,25$

$3,10 \quad 3,74 \quad 4,12$

$3,10 \quad 2,33 \quad 2,77$

$7,77 \quad 4,45 \quad 5,16$

\begin{tabular}{lccc}
\hline & \multicolumn{3}{c}{ Região Sudeste (\%) } \\
\cline { 2 - 4 } & \multicolumn{1}{c}{ 1985 } & 1990 & 1995 \\
\cline { 2 - 4 } A - Agregado II & 36,84 & 34,0 & 33,00 \\
Importações do exterior & 43,96 & 42,3 & 38,68 \\
exportações para o exterior & 30,42 & 20,2 & 24,29 \\
B - Produção Agroindustrial (PAI) & 52,63 & 49,3 & 46,42 \\
Importações do exterior & 48,06 & 50,0 & 50,22 \\
exportações para o exterior & 43,76 & 40,5 & 43,47 \\
Total de exportações (A + B ) & 39,77 & 35,4 & 39,39 \\
\hline
\end{tabular}

A - Agregado II

Importações do exterior exportaçōes para 0 exterior

B - Produção Agroindustrial (PAI)

Importações do exterior exportações para o exterior Total de exportacões $(A+B)$
Região Sul (\%)

\begin{tabular}{rrr}
\hline 1985 & 1990 & 1995 \\
\hline 28,22 & 24,86 & 30,16
\end{tabular}

$33,67 \quad 30,92 \quad 35,34$

$26,38 \quad 24,81 \quad 28,40$

$28,83 \quad 30,71 \quad 33,71$

$30,59 \quad 31,59 \quad 33,05$

$34,33 \quad 31,10 \quad 33,89$

$31,96 \quad 29,52 \quad 32,72$

Fonte: Resultados da pesquisa. Obs.: O total para o Brasil é indicado em valores correntes. 
A análise dos valores das transações do agronegócio do Brasil e das regiões com o exterior indica um balanço (exportações totais menos importações totais) positivo para todas as regiões e para o Brasil em 1985. O balanço de 1990 foi positivo para o Brasil e para a maioria das regiões, exceto a região Sudeste, que importou mais do que exportou. Em 1995 o balanço foi negativo para o Brasil e para as regiões Sudeste, Sul e Centro-Oeste; as outras regiões apresentaram balanço positivo para esse ano.

\subsection{As transações interregionais da região Norte}

As tabelas 7.1 e 7.2 demonstraram o dinamismo das exportações da região Norte do Brasil, influenciada, principalmente, pelos investimentos na minero-metalurgia do complexo Carajás. Entre 1970 e 1990, as exportações brasileiras apresentaram uma taxa de crescimento de $12,8 \%$ ao ano, enquanto a região Norte registrou um crescimento anual nas exportações de $16,0 \%$, perto de $30,0 \%$ superior à média nacional (Buarque et al, 1995). Assim, as exportações da região Norte elevaram sua participação no total exportado pelo Brasil, passando de 3,1\% em 1970 para 5,8\% em 1990, sendo que em 1995 houve uma queda para 5,3\% (tabela 7.1). Entretanto, ocorreu no período 1970/1985 uma redução do coeficiente de exportação da região, diminuindo de 10,6\% para 5,19\%. Nesse mesmo período, o coeficiente do Brasil aumentou de 6,12\% em 1970 para 9,35\% em 1985 (Buarque et al, 1995).

O agronegócio da região Norte apresentou, entre 1985 e 1995, uma relativa diminuição de suas importações e exportações totais. A tabela 7.4 apresenta as transações do agronegócio da região Norte com as outras regiões do país e com o exterior.

Observa-se que do total de insumos utilizados pelo setor de produção agropecuária da região, que constitui o montante do agronegócio, 29,0\% são importados do exterior e de outras regiões do país, para o ano de 1995. Com destaque para as 
importações originárias da região Sudeste que representam $73,6 \%$ desse total. A análise das importações desse segmento mostra uma diminuição da participação das importações no total do montante de 32,9\% em 1985 para 29,0\% em 1995. Entretanto, a participação dos insumos importados do exterior do país nesse total aumentou de $1,1 \%$ para 5,5\% no mesmo período.

Da produção agropecuária da região em 1985, 62,3\% foi exportada; sendo que esse valor diminuiu para 46,5\% em 1990 e teve um aumento para 48,5\% em 1995. Confirmando as informações de que essa região aumentou suas exportações de produtos básicos para o resto do Brasil e para o exterior, como demonstrado na tabela 7.2. As exportações são divididas entre exportações para a demanda intermediária (DI) e exportações para a demanda final (DF). As exportações para a demanda intermediária das outras regiões serão utilizadas como insumos no processo produtivo das regiões, e as exportações para a demanda final destinam-se ao consumo final das regiões. Para o setor de produção agropecuária da região Norte, as exportações DI são mais importantes, representando $62,8 \%$ do total de exportações do setor para o ano de 1995 , ou seja, a região Norte é fornecedora de insumos para a agroindústria das outras regiões do país.

A pequena agroindústria da região Norte exporta sua produção para o exterior e para a demanda intermediária e final das outras regiões do país. A participação dessas exportações no total produzido diminuiu de $35,5 \%$ em 1985 para $31,9 \%$ em 1995 . O destaque são as exportações para o exterior que aumentaram sua parcela no total de exportações de 18,0\% em 1985 para 43,5\% em 1995. Nesse ano, as exportações DI representaram $24,4 \%$ e as exportações DF participaram com $32,1 \%$ do total de exportações.

Seguindo a tendência de diminuição relativa das exportações, observa-se que a participação do total de exportações no total produzido pelo agronegócio da região cai de $31,2 \%$ em 1985 para 25,5\% em 1995, porém, essa participação é uma das maiores do país. . E o coeficiente de exportações do agronegócio no PIB regional também diminui de $9,4 \%$ em 1985 para $6,7 \%$ em 1995 , refletindo a queda do próprio agronegócio na constituição do PIB da região (última linha da tabela 7.4). 
Tabela 7.4: As transações comerciais do agronegócio da região Norte.

\begin{tabular}{|c|c|c|c|c|c|c|}
\hline Região Norte & 1985 & & 1990 & & 1995 & \\
\hline Agregados do agronegócios & Valores & $\%$ & Valores & $\%$ & Valores & $\%$ \\
\hline I-Montante & 2803,7 & & 89553,5 & & 1055555,4 & \\
\hline Total de importações & 923,2 & 100,0 & 31082,5 & 100,0 & 306370,7 & 100,0 \\
\hline Importados exterior & 10,0 & 1,1 & 699,0 & 2,2 & 16770,8 & 5,5 \\
\hline Importações do NE & 46,4 & 5,0 & 1698,0 & 5,5 & 14556,1 & 4,8 \\
\hline Importaçōes do $\mathrm{CO}$ & 14,5 & 1,6 & 840,2 & 2,7 & 4586,5 & 1,5 \\
\hline Importações do SE & 716,7 & 77,6 & 24425,6 & 78,6 & 225346,1 & 73,6 \\
\hline Importações do SU & 135,7 & 14,7 & 3419,8 & 11,0 & 45111,4 & 14,7 \\
\hline Importações / montante & & 32,9 & & 34,7 & & 29,0 \\
\hline II - Produção Agropecuária (PA) & 6842,8 & & 179638,9 & & 2961575,4 & \\
\hline Total de exportações - PA & 4259,9 & 100,0 & 83473,5 & 100,0 & 1436156,8 & 100,0 \\
\hline exportações para o Exterior & 290,4 & 6,8 & 9386,7 & 11,2 & 76379,7 & 5,3 \\
\hline Total de exportações DI & 2411,6 & 56,6 & 53745,6 & 64,4 & 901389,2 & 62,8 \\
\hline exportações DI para NE & 55,2 & 1,3 & 877,5 & 1,1 & 15157,6 & 1,1 \\
\hline exportações DI para CO & 151,2 & 3,6 & 2960,4 & 3,5 & 61536,8 & 4,3 \\
\hline exportações DI para SE & 1256,4 & 29,5 & 28801,8 & 34,5 & 447414,1 & 31,2 \\
\hline exportações DI para SUL & 948,8 & 22,3 & 21105,8 & 25,3 & 377280,7 & 26,3 \\
\hline Total de exportações DF & 1557,9 & 36,6 & 20341,2 & 24,4 & 458387,9 & 31,9 \\
\hline exportações DF para NE & 9,4 & 0,2 & 137,2 & 0,2 & 2867,7 & 0,2 \\
\hline exportaçōes DF para CO & 104,0 & 2,4 & 1471,8 & 1,8 & 37410,8 & 2,6 \\
\hline exportações DF para SE & 1111,9 & 26,1 & 14841,8 & 17,8 & 317973,7 & 22,1 \\
\hline exportações DF para SUL & 332,7 & 7,8 & 3890,3 & 4,7 & 100135,7 & 7,0 \\
\hline Exportaçōes / PA & & 62,3 & & 46,5 & & 48,5 \\
\hline III - Jusante & 7835,5 & & 226518,1 & & 3360990,0 & \\
\hline Produção Agroindustrial (PAI) & 3389,7 & & 96467,3 & & 1402198,2 & \\
\hline Total de exportações - PAI & 1203,0 & 100,0 & 33275,0 & 100,0 & 446870,8 & 100,0 \\
\hline exportações para o Exterior & 215,9 & 18,0 & 15684,4 & 47,1 & 194300,4 & 43,5 \\
\hline Total de exportações DI & 371,0 & 30,8 & 8118,7 & 24,4 & 108908,2 & 24,4 \\
\hline exportações DI para NE & 8,4 & 0,7 & 168,2 & 0,5 & 2467,5 & 0,6 \\
\hline exportaçōes DI para CO & 27,2 & 2,3 & 555,2 & 1,7 & 10487,0 & 2,3 \\
\hline exportações DI para SE & 232,7 & 19,3 & 5130,6 & 15,4 & 60578,0 & 13,6 \\
\hline exportações DI para SUL & 102,6 & 8,5 & 2264,8 & 6,8 & 35375,8 & 7,9 \\
\hline Total de exportações DF & 616,1 & 51,2 & 9471,8 & 28,5 & 143662,2 & 32,1 \\
\hline exportações DF para NE & 53,3 & 4,4 & 697,9 & 2,1 & 11296,7 & 2,5 \\
\hline exportações DF para CO & 37,8 & 3,1 & 617,4 & 1,9 & 10866,3 & 2,4 \\
\hline exportações DF para SE & 404,1 & 33,6 & 6506,7 & 19,6 & 92403,6 & 20,7 \\
\hline exportações DF para SUL & 120,9 & 10,1 & 1649,9 & 5,0 & 29095,6 & 6,5 \\
\hline Exportações / PAI & & 35,5 & & 34,5 & & 31,9 \\
\hline Total de exportações (PA + PAI) & 5462,9 & & 116748,5 & & 1883027,6 & \\
\hline AGRONEGÓCIO & 17482,1 & & 495710,4 & & 7378120,8 & \\
\hline Exportações Totais / Agronegócio & & 31,2 & & 23,6 & & 25,5 \\
\hline PIB regional & 58085,7 & & 1589858,5 & & 28185311,7 & \\
\hline Exportações Totais / PIB regional & & 9,4 & & 7,3 & & 6,7 \\
\hline Agronegócio / PIB regional & & 30,1 & & 31,2 & & 26,2 \\
\hline
\end{tabular}

Fonte: Resultados da pesquisa. Obs.: Os valores são indicados em moeda corrente. 


\subsection{As transações interregionais da região Nordeste}

A economia da região Nordeste apresentou entre 1985 e 1995 uma diminuição de sua parcela nas exportações brasileiras, como foi observado na tabela 7.1. Esta diminuição ocorreu principalmente com relação aos produtos básicos e semimanufaturados (tabela 7.2). Dentro da região, os Estados que aumentaram suas vendas para o mercado externo entre 1975 e 1990 foram o Maranhão, Piauí, Sergipe, Bahia e Ceará; enquanto os Estados de Alagoas e Pernambuco exportaram em 1990 um valor menor do que em 1975 (Araújo, 1995).

Com relação à pauta de exportações do Nordeste, Araújo (1995) apresenta informações que mostram um grande crescimento das relações com o exterior via vendas de manufaturados, sendo que, entre 1975 e 1990, o peso relativo dos manufaturados no total exportado pela região aumentou de $12,9 \%$ para $44,9 \%$. Embora na pauta nordestina os produtos semimanufaturados tenham tido, em 1990, maior peso relativo que o mesmo item na pauta brasileira, respectivamente, $30,1 \%$ e $16,5 \%$.

O mercado extra-regional prevalece como destino da produção de alguns segmentos da indústria de transformação, caso de bebidas (99\%), borracha (88\%), couros e peles $(87 \%)$, material elétrico $(76 \%)$ e química $(61 \%)$. Os equipamentos utilizados na montagem do novo parque industrial foram importados do Sudeste (49\%) e do exterior (33\%) (dados da SUDENE e BNB, 1992; citados por Araújo, 1995).

A autora também destaca as relações econômicas extra-regionais estabelecidas pelos novos pólos agrícolas do Nordeste, com destaque para a soja do oeste baiano, do sul do Maranhão e do Piauí. A produção agroindustrial associada à irrigação tanto no Vale do São Francisco (BA e PE) como no Vale do Açu (RN).

O comércio interregional do agronegócio nordestino sofreu o impacto da diminuição das exportações da região, pois a participação das exportações totais desse setor no PIB regional caíram de 3,5\% em 1985 para 2,4\% no ano de 1995, uma das 
menores participações entre todas as regiões do país. O setor exportou para o exterior e para as outras regiões do país 8,4\% de sua produção em 1995; o que representou uma queda comparando com 1985, cuja exportação representou 9,3\%, como pode se observado nas últimas linhas da tabela 7.5 .

As importações de insumos utilizados pela agropecuária da região situou-se em torno de $20,0 \%$ do total, para o período $1985 / 1995$, sendo que as importações do exterior aumentaram sua participação no total importado de 3,1\% em 1985, para 6,8\% em 1990; e 13,8\% em 1995. Internamente, a maior parcela das importações são originárias da região Sudeste $(64,8 \%$ em 1995$)$.

A região Nordeste exporta relativamente pouco de sua produção agropecuária, apenas $11,6 \%$ da produção foi exportada em 1995. Sendo que desse total $2,2 \%$ foi exportado para o exterior, $42,4 \%$ foram exportações DI para as regiões do Brasil, e $34,4 \%$ foram exportações DF, ou seja, a maior parte das exportações da agropecuária da região Nordeste vai servir como insumo nas agroindústrias das outras regiões do país. Internamente, as maiores exportações são para a região Sudeste do país; um total (DI+DF) de 44,4\%.

As exportações da agroindústria da região Nordeste corresponderam para os anos de 1985, 1990 e 1995, respectivamente, 30,5\%, 28,0\% e 27,9\% do total produzido por esse segmento do agronegócio da região. Ocorreu, portanto, uma diminuição relativa das exportações desse segmento. Um detalhe importante é que mais da metade dessas exportações tem como destino outros países, como ocorreu em 1995 quando 52,4\% das exportações foram para o exterior. Internamente, o maior comprador de produtos das agroindústrias do Nordeste é a região Sudeste do país. A maior parte das exportações por vias internas desse setor tem como destino a demanda intermediária das regiões. 
Tabela 7.5: As transações comerciais do agronegócio da região Nordeste.

\begin{tabular}{|c|c|c|c|c|c|c|}
\hline Região Nordeste & 1985 & & 1990 & & 1995 & \\
\hline Agregados do agronegócio & Valores & $\%$ & Valores & $\%$ & Valores & $\%$ \\
\hline I - Montante & 9179,7 & & 213372,0 & & 2922013,7 & \\
\hline Total de importações & 1894,1 & 100,0 & 47568,5 & 100,0 & 585716,8 & 100,0 \\
\hline Importados exterior & 59,1 & 3,1 & 3222,7 & 6,8 & 80970,3 & 13,8 \\
\hline Importações do $\mathrm{N}$ & 5,6 & 0,3 & 88,0 & 0,2 & 1712,4 & 0,3 \\
\hline Importações do $\mathrm{CO}$ & 34,5 & 1,8 & 1306,4 & 2,7 & 10359,4 & 1,8 \\
\hline Importações do SE & 1416,8 & 74,8 & 35452,3 & 74,5 & 379395,8 & 64,8 \\
\hline Importações do SU & 378,1 & 20,0 & 7499,1 & 15,8 & 113279,1 & 19,3 \\
\hline Importações / montante & & 20,6 & & 22,3 & & 20,0 \\
\hline II - Produção Agropecuária (PA) & 26418,7 & & 532213,6 & & 9047713,6 & \\
\hline Total de exportações - PA & 2675,0 & 100,0 & 58700,0 & 100,0 & 1048776,9 & 100,0 \\
\hline exportações para o Exterior & 1141,9 & 42,7 & 15914,7 & 27,1 & 242956,5 & 23,2 \\
\hline Total de exportações DI & 908,4 & 34,0 & 25832,6 & 44,0 & 444977,8 & 42,4 \\
\hline exportações DI para $\mathrm{N}$ & 1,4 & 0,1 & 46,9 & 0,1 & 922,2 & 0,1 \\
\hline exportações DI para CO & 66,5 & 2,5 & 1677,0 & 2,9 & 36291,0 & 3,5 \\
\hline exportações DI para SE & 495,6 & 18,5 & 14487,7 & 24,7 & 228532,1 & 21,8 \\
\hline exportações DI para SUL & 344,8 & 12,9 & 9621,0 & 16,4 & 179232,6 & 17,1 \\
\hline Total de exportações DF & 624,7 & 23,4 & 16952,7 & 28,9 & 360842,5 & 34,4 \\
\hline exportações DF para $\mathrm{N}$ & 34,5 & 1,3 & 1176,5 & 2,0 & 21895,8 & 2,1 \\
\hline exportações DF para CO & 39,6 & 1,5 & 1147,9 & 2,0 & 27843,9 & 2,7 \\
\hline exportações DF para SE & 423,8 & 15,8 & 11593,2 & 19,7 & 236590,1 & 22,6 \\
\hline exportações DF para SUL & 126,8 & 4,7 & 3035,2 & 5,2 & 74512,6 & 7,1 \\
\hline Exportações / PA & & 10,1 & & 11,0 & & 11,6 \\
\hline III - Jusante & 37598,5 & & 775257,1 & & 12132242,7 & \\
\hline Produção Agroindustrial (PAI) & 13513,8 & & 226578,6 & & 3491705,6 & \\
\hline Total de exportações - PAI & 4118,2 & 100,0 & 63391,9 & 100,0 & 972739,0 & 100,0 \\
\hline exportações para o Exterior & 2374,0 & 57,6 & 28843,4 & 45,5 & 509495,5 & 52,4 \\
\hline Total de exportações DI & 1134,4 & 27,5 & 22929,3 & 36,2 & 289456,2 & 29,8 \\
\hline exportações DI para $N$ & 20,9 & 0,5 & 593,0 & 0,9 & 10111,3 & 1,0 \\
\hline exportações DI para CO & 28,9 & 0,7 & 790,3 & 1,2 & 11957,1 & 1,2 \\
\hline exportações DI para SE & 793,3 & 19,3 & 15093,0 & 23,8 & 176751,1 & 18,2 \\
\hline exportações DI para SUL & 291,3 & 7,1 & 6453,1 & 10,2 & 90636,7 & 9,3 \\
\hline Total de exportações DF & 609,8 & 14,8 & 11619,2 & 18,3 & 173787,3 & 17,9 \\
\hline exportações DF para $\mathrm{N}$ & 196,6 & 4,8 & 5481,9 & 8,6 & 67521,3 & 6,9 \\
\hline exportações DF para CO & 27,7 & 0,7 & 469,5 & 0,7 & 8633,5 & 0,9 \\
\hline exportações DF para SE & 296,7 & 7,2 & 4445,2 & 7,0 & 74311,0 & 7,6 \\
\hline exportações DF para SUL & 88,8 & 2,2 & 1222,5 & 1,9 & 23321,4 & 2,4 \\
\hline Exportações / PAI & & 30,5 & & 28,0 & & 27,9 \\
\hline Total de exportações (PA + PAI) & 6793,2 & & 122091,9 & & 2021515,8 & \\
\hline AGRONEGÓCIO & 73197,0 & & 1520842,6 & & 24101970,0 & \\
\hline Exportações Totais / Agronegócio & & 9,3 & & 8,0 & & 8,4 \\
\hline PIB regional & 193262,3 & & 4909440,7 & & 85087465,1 & \\
\hline Exportações Totais / PIB regior & & 3,5 & & 2,5 & & 2,4 \\
\hline Agronegócio / PIB regional & & 37,9 & & 31,0 & & 28,3 \\
\hline
\end{tabular}

Fonte: Resultados da pesquisa. Obs.: Os valores são indicados em moeda corrente. 


\subsection{As transações interregionais da região Centro-Oeste}

Apesar da baixa participação da região Centro-Oeste no total exportado pelo Brasil, apenas 2,2\% em 1995 (tabela 7.1); a região vem apresentando elevadas taxas de crescimento de suas exportações. Analisando-se o desempenho dentro da região, o destaque é o Estado do Mato Grosso, que entre 1985 e 1990, apresentou uma taxa de crescimento de $42 \%$ ao ano, sendo a maior média do período entre todas as unidades federativas do Brasil (Galindo \& Santos, 1995).

O bom desempenho apresentado pelas exportações da região foi devido à expansão das exportações de produtos básicos, principalmente os grãos (soja, trigo, arroz, etc.). Galindo \& Santos (1995) analisam a pauta de exportações da região e verificam que a participação relativa dos produtos básicos aumenta de 62,4\% em $1975 \mathrm{e}$ $82,1 \%$ em 1990, "enquanto a participação em nível nacional caiu de 54,7\% para $28,4 \%$ ".

A caracterização da região Centro-Oeste como uma grande exportadora de produtos básicos para as outras regiões do Brasil fica evidente quando analisa-se os resultados apresentados na tabela 7.6. Entretanto, existe uma tendência que aponta para a diminuição desse papel no contexto das transações extra-regionais dessa região do país, um dos resultados indica que o total da produção agropecuária exportado diminuiu de $59,8 \%$ em 1985 para $50,3 \%$ em 1995.

As importações do setor agropecuário da região Centro-Oeste representaram $33,4 \%$ dos insumos utilizados pelo setor em 1985, sendo que houve uma diminuição dessa participação das importações para 1995, ficando em $29,9 \%$ do total de insumos utilizados pelo setor. Este resultado indica uma menor dependência da região com relação aos insumos produzidos nas outras regiões do país. As importações do exterior aumentaram de 2,2\% em 1985 para 10,5\% em 1995, reflexo da abertura comercial dos anos 90 . 
As exportações da produção agropecuária da região Centro-Oeste representaram mais da metade da produção do setor no período de análise. O mercado externo perdeu espaço, caindo as exportações para o exterior de 16,0\% em 1985 para $3,7 \%$ em 1995. As exportações por vias internas desse setor são quase que totalmente direcionadas para a demanda intermediária, representando $80,9 \%$ do total exportado em 1995; e o grande mercado consumidor desse setor são as agroindústrias da região Sudeste.

O setor de produção agroindustrial da região Centro-Oeste exportou nos anos de 1985,1990 e 1995 , respectivamente, $38,6 \%, 35,6 \%$ e $31,9 \%$ de sua produção. Sendo que o mercado externo diminuiu sua participação de $41,9 \%$ para $23,1 \%$ no total exportado entre 1985 e 1995. A maior parte das exportações desse segmento do agronegócio tem como destino a demanda final das regiões do Brasil (55,1\% em 1995), principalmente para a região Sudeste.

A parcela da produção do agronegócio da região Centro-Oeste que foi exportadas representava $24,2 \%$ em 1985 , diminuiu para $22,4 \%$ em 1990 e para $22,1 \%$ em 1995. Apesar dessa queda, pode-se concluir, comparando com os resultados obtidos para as outras regiões do país, que essa parcela é elevada. E indica a importância do agronegócio na integração da região na economia brasileira. A participação das exportações do agronegócio na composição do $\mathrm{PIB}$ da região também é relativamente elevada, apesar de apresentar uma queda de 11,7\% em 1985 para 8,4\% em 1995. 
Tabela 7.6: As transações comerciais do agronegócio da região Centro-Oeste.

\begin{tabular}{|c|c|c|c|c|c|c|}
\hline Região Centro-Oeste & 1985 & & 1990 & & 1995 & \\
\hline Agregados do agronegócios & Valores & $\%$ & Valores & $\%$ & Valores & $\%$ \\
\hline I - Montante & 8403,5 & & 174547,3 & & 5209601,4 & \\
\hline Total de importações & 2809,4 & 100,0 & 48105,4 & 100,0 & 1556051,1 & 100,0 \\
\hline Importados exterior & 63,0 & 2,2 & 3517,6 & 7,3 & 162831,7 & 10,5 \\
\hline Importações do $\mathrm{N}$ & 157,6 & 5,6 & 1446,7 & 3,0 & 93911,1 & 6,0 \\
\hline Importações do NE & 152,9 & 5,4 & 2883,5 & 6,0 & 82615,9 & 5,3 \\
\hline Importações do SE & 1898,7 & 67,6 & 32104,9 & 66,7 & 902907,3 & 58,0 \\
\hline Importações do SU & 537,2 & 19,1 & 8152,6 & 16,9 & 313785,0 & 20,2 \\
\hline Importações / montante & & 33,4 & & 27,6 & & 29,9 \\
\hline II - Produção Agropecuária (PA) & 11447,6 & & 233820,1 & & 7238459,8 & \\
\hline Total de exportações - PA & 6842,9 & 100,0 & 134042,5 & 100,0 & 3637859,5 & 100,0 \\
\hline exportações para o Exterior & 1098,0 & 16,0 & 6161,6 & 4,6 & 133891,8 & 3,7 \\
\hline Total de exportações DI & 4969,0 & 72,6 & 100635,8 & 75,1 & 2942698,4 & 80,9 \\
\hline exportaçōes DI para $\mathrm{N}$ & 0,9 & 0,0 & 19,1 & 0,0 & 694,0 & 0,0 \\
\hline exportações DI para NE & 93,6 & 1,4 & 1244,8 & 0,9 & 41985,0 & 1,2 \\
\hline exportaçōes DI para SE & 4855,9 & 71,0 & 99013,1 & 73,9 & 2890825,1 & 79,5 \\
\hline exportações DI para SUL & 18,8 & 0,3 & 358,8 & 0,3 & 9194,4 & 0,3 \\
\hline Total de exportações DF & 775,9 & 11,3 & 27245,2 & 20,3 & 561269,3 & 15,4 \\
\hline exportações DF para $\mathrm{N}$ & 7,0 & 0,1 & 304,9 & 0,2 & 5765,1 & 0,2 \\
\hline exportaçōes DF para NE & 31,3 & 0,5 & 1229,5 & 0,9 & 23895,1 & 0,7 \\
\hline exportações DF para SE & 736,8 & 10,8 & 25686,8 & 19,2 & 531049,2 & 14,6 \\
\hline exportações DF para & 0,8 & 0,0 & 24,0 & 0,0 & 559,9 & 0,0 \\
\hline Exportações / PA & & 59,8 & & 57,3 & & 50,3 \\
\hline III - Jusante & 12646,0 & & 299477,9 & & 5941769,7 & \\
\hline Produção Agroindustrial (PAI) & 2640,1 & & 68204,5 & & 1331741,2 & \\
\hline Total de exportações - PAI & 1018,5 & 100,0 & 24312,1 & 100,0 & 424699,3 & 100,0 \\
\hline exportações para o Exterior & 426,9 & 41,9 & 3977,1 & 16,4 & 98282,1 & 23,1 \\
\hline Total de exportações DI & 206,8 & 20,3 & 5636,5 & 23,2 & 92203,0 & 21,7 \\
\hline exportaçōes DI para $\mathrm{N}$ & 2,9 & 0,3 & 92,0 & 0,4 & 1616,3 & 0,4 \\
\hline exportações DI para NE & 22,2 & 2,2 & 572,6 & 2,4 & 9096,2 & 2,1 \\
\hline exportações DI para SE & 167,8 & 16,5 & 4365,5 & 18,0 & 74454,2 & 17,5 \\
\hline exportações DI para SUL & 14,0 & 1,4 & 606,4 & 2,5 & 7036,4 & 1,7 \\
\hline Total de exportações DF & 384,8 & 37,8 & 14698,5 & 60,5 & 234214,2 & 55,1 \\
\hline exportações DF para $N$ & 13,7 & 1,3 & 647,2 & 2,7 & 9097,4 & 2,1 \\
\hline exportações DF para NE & 66,9 & 6,6 & 2764,9 & 11,4 & 42618,3 & 10,0 \\
\hline exportações DF para SE & 299,8 & 29,4 & 11144,9 & 45,8 & 179980,7 & 42,4 \\
\hline exportaçōes DF para SUL & 4,3 & 0,4 & 141,4 & 0,6 & 2517,8 & 0,6 \\
\hline Exportações / PAI & & 38,6 & & 35,6 & & 31,9 \\
\hline Total de exportaçóes (PA + PAI) & 7861,4 & & 158354,6 & & 4062558,8 & \\
\hline AGRONEGÓCIO & 32497,2 & & 707845,3 & & 18389830,8 & \\
\hline Exportações Totais / Agronegócio & & 24,2 & & 22,4 & & 22,1 \\
\hline PIB regional & 66916,2 & & 1934111,6 & & 48218984,3 & \\
\hline Exportações Totais / PIB regional & & 11,7 & & 8,2 & & 8,4 \\
\hline Agronegócio / PIB regional & & 48,6 & & 36,6 & & 38,1 \\
\hline
\end{tabular}

Fonte: Resultados da pesquisa. Obs.: Os valores são indicados em moeda corrente. 


\subsection{As transações interregionais da região Sudeste}

As exportações da região Sudeste representaram, em 1995, 58,3\% do total brasileiro (tabela 7.1); sendo que essa parcela é ainda maior quando se analisa as exportações de produtos manufaturados, em que a participação do Sudeste, em 1990, correspondeu a 71,8\% do total vendido pelo Brasil (tabela 7.2). O Sudeste também lidera as exportações de produtos básicos e semimanufaturados.

Internamente, a pauta de exportações da região Sudeste apresentou alterações entre 1975 e 1990; os produtos básicos perderam uma parcela importante das exportações regionais no período, 40,8\% em 1975 e 19,9\% em 1990; a parcela dos semimanufaturados foi de $9,2 \%$ para $15,0 \%$; e a dos manufaturados foi de $47,8 \%$ para 64,3\% no mesmo período (CACEX, citado por Diniz \& Santos, 1995). Esses autores concluem que " $a$ expansão das exportações brasileiras foi acompanhada por um movimento de reafirmação da região Sudeste como centro econômico do país, especialmente no que se refere à produção manufatureira ..., notadamente nos estados de São Paulo e Minas Gerais".

A região Sudeste possui um grande mercado consumidor para os produtos do agronegócio, portanto, é a região que menos exporta produtos agropecuários e agroindustriais relativamente ao total da produção desses setores. Além disso, como visto nas análises referentes às outras regiōes, a região Sudeste é um importante mercado consumidor para a produção do agronegócio das demais regiões do Brasil. Nesse sentido, os resultados obtidos para a referida região indicam que em 1995 foram exportados apenas 5,3\% do total produzido pelo agronegócio da região; sendo que essas exportações tiveram uma parcela de $1,2 \%$ no PIB da região (tabela 7.7 ).

Ao contrário do percebido para as outras regiões do país, a participação dos insumos importados no total de insumos utilizado pelo setor agropecuário da região Sudeste apresentou um aumento no período analisado, pois essa relação que era de 
23,2\% em 1985, foi para 28,6\% em 1995. Os maiores fornecedores de insumos para o Sudeste em 1995 foram, pela ordem, a região Sul, com 57,4\% do total; a região CentroOeste, com 17,7\%; e o exterior, com $11,9 \%$.

As exportações do setor agropecuário da região Sudeste; que já eram relativamente baixas em 1985 , com uma participação de $8,1 \%$ no total produzido pelo setor; diminuíram para 5,7\% do total produzido em 1990; e para 5,5\% em 1995. A participação das exportações para o exterior no total exportado, que foi de quase 50,0\% em 1985, caiu para $24,4 \%$ em 1995 , como demonstra os resultados apresentados na tabela 7.7. Nesse ano, $53,5 \%$ das exportações do setor foram por vias internas para a demanda final das demais regiões do país, com destaque para as regiões Sul $(30,5 \%)$ e Nordeste $(16,0 \%)$.

A análise das exportações do setor de produção agroindustrial da região Sudeste revela um setor que direciona suas exportações para o exterior e para a demanda final das outras regiões do país; ou seja, exporta produtos prontos para o consumo final. Os resultados revelam que, em 1995, 51,5\% do total exportado pelas agroindústrias dessa região tiveram como destino países do exterior; $32,3 \%$ forma para a demanda final das demais regiões do país; e 16,2\% foram para a demanda intermediária das regiões brasileiras. Ao contrário do ocorrido para as outras regiões, a participação das exportações no total produzido pelo setor agroindustrial do Sudeste aumentou no período de análise, porém, essa participação é relativamente menor do que as apresentadas pelas demais regiões do país. O motivo, como já foi destacado, é a grandeza do mercado interno do Sudeste.

A parcela da produção do agronegócio da região Sudeste que foi exportada representava 6,3\% em 1985, diminuiu para 4,9\% em 1990, e subiu um pouco chegando a 5,3\% em 1995. A participação das exportações do agronegócio na composição do PIB da região também é relativamente baixa, fícando próximo de 1,0\% em 1990 e 1995. 
Tabela 7.7: As transações comerciais do agronegócio da região Sudeste.

\begin{tabular}{|c|c|c|c|c|c|c|}
\hline Região Sudeste & 1985 & & 1990 & & 1995 & \\
\hline Agregados do agronegócios & Valores & $\%$ & Valores & $\%$ & Valores & $\%$ \\
\hline I - Montante & 34378,1 & & 628826,6 & & 11343842,2 & \\
\hline Total de importações & 7979,2 & 100,0 & 156842,0 & 100,0 & 3248946,4 & 100,0 \\
\hline Importados exterior & 259,5 & 3,3 & 11778,4 & 7,5 & 387889,0 & 11,9 \\
\hline Importações do $\mathrm{N}$ & 649,0 & 8,1 & 6312,6 & 4,0 & 223710,0 & 6,9 \\
\hline Importações do NE & 629,7 & 7,9 & 12581,9 & 8,0 & 196803,2 & 6,1 \\
\hline Importações do $\mathrm{CO}$ & 1562,9 & 19,6 & 36441,5 & 23,2 & 575266,9 & 17,7 \\
\hline Importaçōes do SU & 4878,0 & 61,1 & 89727,5 & 57,2 & 1865277,4 & 57,4 \\
\hline Importações / montante & & 23,2 & & 24,9 & & 28,6 \\
\hline II - Produção Agropecuária (PA) & 47148,7 & & 782935,6 & & 17243066,5 & \\
\hline Total de exportações - PA & 3823,8 & 100,0 & 44808,7 & 100,0 & 951997,4 & 100,0 \\
\hline exportaçōes para o Exterior & 1781,2 & 46,6 & 11543,6 & 25,8 & 232745,4 & 24,4 \\
\hline Total de exportações DI & 1612,2 & 42,2 & 22809,6 & 50,9 & 509769,1 & 53,5 \\
\hline exportações DI para N & 9,1 & 0,2 & 144,9 & 0,3 & 3925,6 & 0,4 \\
\hline exportações DI para NE & 525,6 & 13,7 & 5893,6 & 13,2 & 152308,8 & 16,0 \\
\hline exportações DI para CO & 106,2 & 2,8 & 2408,3 & 5,4 & 63491,6 & 6,7 \\
\hline exportações DI para SUL & 971,3 & 25,4 & 14362,9 & 32,1 & 290043,1 & 30,5 \\
\hline Total de exportações DF & 430,4 & 11,3 & 10455,5 & 23,3 & 209482,8 & 22,0 \\
\hline exportações DF para $\mathrm{N}$ & 63,3 & 1,7 & 1706,7 & 3,8 & 32591,1 & 3,4 \\
\hline exportações DF para NE & 300,9 & 7,9 & 7296,5 & 16,3 & 143359,0 & 15,1 \\
\hline exportações DF para CO & 35,5 & 0,9 & 851,2 & 1,9 & 19405,9 & 2,0 \\
\hline exportações DF para SUL & 30,7 & 0,8 & 601,2 & 1,3 & 14127,0 & 1,5 \\
\hline Exportações / PA & & 8,1 & & 5,7 & & 5,5 \\
\hline III - Jusante & 145951,5 & & 2934307,6 & & 45349793,2 & \\
\hline Produção Agroindustrial (PAI) & 55482,9 & & 965160,4 & & 14546968,3 & \\
\hline Total de exportações - PAI & 10590,6 & 100,0 & 168203,2 & 100,0 & 2987749,8 & 100,0 \\
\hline exportações para o Exterior & 6024,4 & 56,9 & 69200,1 & 41,1 & 1540120,2 & 51,5 \\
\hline Total de exportações DI & 1703,6 & 16,1 & 33133,3 & 19,7 & 483975,7 & 16,2 \\
\hline exportações DI para N & 89,8 & 0,8 & 2116,1 & 1,3 & 35596,6 & 1,2 \\
\hline exportações DI para NE & 707,0 & 6,7 & 11844,6 & 7,0 & 160227,3 & 5,4 \\
\hline exportações DI para CO & 242,0 & 2,3 & 5610,0 & 3,3 & 95351,9 & 3,2 \\
\hline exportações DI para SUL & 664,9 & 6,3 & 13562,6 & 8,1 & 192799,9 & 6,5 \\
\hline Total de exportações DF & 2862,6 & 27,0 & 65869,7 & 39,2 & 963653,9 & 32,3 \\
\hline exportações DF para $\mathrm{N}$ & 549,3 & 5,2 & 13549,2 & 8,1 & 178046,7 & 6,0 \\
\hline exportações DF para NE & 1635,6 & 15,4 & 38009,4 & 22,6 & 547680,2 & 18,3 \\
\hline exportações DF para CO & 423,1 & 4,0 & 8701,6 & 5,2 & 129916,1 & 4,3 \\
\hline exportações DF para SUL & 254,6 & 2,4 & 5609,6 & 3,3 & 108010,9 & 3,6 \\
\hline Exportações / PAI & & 19,1 & & 17,4 & & 20,5 \\
\hline Total de exportaçóes $(\mathrm{PA}+\mathrm{PAI})$ & 14414,4 & & 213011,9 & & 3939747,2 & \\
\hline AGRONEGÓCIO & 227478,2 & & 4346069,7 & & 73936701,9 & \\
\hline Exportações Totais / Agronegócio & & 3 & & 4,9 & & 5,3 \\
\hline PIB regional & 747569,7 & & 18174845,6 & & 318762122,0 & \\
\hline Exportações Totais / PIB regional & & 1,9 & & 1,2 & & 1,2 \\
\hline Agronegócio / PIB regional & & 30,4 & & 23,9 & & 23,2 \\
\hline
\end{tabular}

Fonte: Resultados da pesquisa. Obs.: Os valores são indicados em moeda corrente. 


\subsection{As transações interregionais da região $\mathrm{Sul}$}

A participação da região Sul no total de exortações da economia brasileira apresentou um decréscimo de 3,0\% entre 1970 e 1990, porém houve uma recuperação entre o período de 1990 e 1995, voltando essa região a participar com 25,0\% das exportações do Brasil (tabela 7.1). Em 1990, a região Sul participava com 33,0\% do total das exportações brasileiras de produtos básicos; $12,9 \%$ das exportações de produtos semimanufaturados ; e 18,9\% das exportações de produtos manufaturados (tabela 7.2). Sendo que o principal aumento deu-se nessa última classe de produtos, mostrando o elevado dinamismo das exportações industriais da região.

Bandeira (1995) evidencia a "elevada diversificação das exportações do Sul no que diz respeito às empresas. Enquanto na grande maioria dos estados as cinco principais firmas exportadoras são responsáveis por uma parcela muito elevada das vendas para o exterior, nos estados sulinos sua participação é bastante reduzida. $\mathrm{Na}$ verdade, em 1991, apenas São Paulo apresentava uma diversificação por empresas maior do que o Paraná e o Rio Grande do Sul".

A importância do agronegócio para a região Sul já foi bastante destacado nessa pesquisa, porém, os resultados nesse capítulo obtidos demonstram novamente essa importância. A participação do total de exportações do agronegócio regional em relação ao PIB da região Sul é a maior entre todas as regiões do país, apesar da queda ocorrida entre o período de 1985 a 1995.

A região Sul apresenta pouca dependência com relação à utilização de insumos importados; a participação desses insumos no total utilizado pelo setor agropecuário da região foi de 19,8\% nos anos de 1985 e 1995 (tabela 7.8). A parcela de insumos importados do exterior no total utilizado aumentou no mesmo período; $3,7 \%$ em 1985 para $16,8 \%$ em 1995. Internamente, a maior parte dos insumos são importados da região Sudeste do país, 62,9\% em 1995. 
O setor de produção agropecuária da região Sul exportou, nos anos de 1985, 1990 e 1995 , respectivamente, $34,0 \%, 34,9 \%$ e $30,8 \%$ do total de sua produção, como indicam os resultados apresentados na tabela 7.8. Portanto, houve uma queda da participação das exportações. A maior parte dessas vendas se dá por vias internas e para a demanda intermediária das regiões, 67,1\% em 1985 e 67,9\% em 1995. O maior mercado consumidor é a região Sudeste que adquiriu, em 1995, 85,6\% do total das exportações do setor agropecuário da região Sul, sendo $67,1 \%$ para demanda intermediária e 23,9\% para demanda final. As exportações para o exterior são relativamente baixas, ficando em 5,6\% do total exportado em 1995 .

O setor de produção agroindustrial da região Sul é o que relativamente mais exporta a sua produção, comparando com as agroindústrias das demais regiões do país. As exportações da agroindústria da região Sul, representaram, nos anos de 1985, 1990 e 1995 , respectivamente, $54,8 \%, 47,1 \%$ e $46,5 \%$ do total produzido por este segmento do agronegócio da região (tabela 7.8). Essas exportações foram constituídas, em 1995, da seguinte forma: $24,4 \%$ foi para o exterior, $22,6 \%$ foi para a demanda intermediária das demais regiões do país, e $53,0 \%$ foi para a demanda final, principalmente para a região Sudeste. Ou seja, a maior parte das exportações da agroindústria da região Sul do Brasil constitui-se de produtos processados, prontos para o consumo final.

A relação entre o total de exportações e o total produzido pelo agronegócio da região Sul foi de 20,0\% para 1985, 17,4\% para 1990 e 18,4\% em 1995. A participação dessas exportações no PIB da região apresentou, para esses mesmos anos, os seguintes valores, $13,5 \%, 9,4 \%$ e 9,7\%. Ou seja, praticamente 10,0\% do PIB da região Sul é constituído por exportações originadas do setor de agronegócios da região. 
Tabela 7.8: As transações comerciais do agronegócio da região Sul.

\begin{tabular}{|c|c|c|c|c|c|c|}
\hline Região Sul & 1985 & & 1990 & & 1995 & \\
\hline Agregados do agronegócios & Valores & $\%$ & Valores & $\%$ & Valores & \\
\hline I - Montante & 26822,8 & & 442900,7 & & 10692226,6 & \\
\hline Total de importações & 5308,0 & 100,0 & 94582,6 & 100,0 & 2114268,7 & 100,0 \\
\hline Importados exterior & 198,8 & 3,7 & 8602,4 & 9,1 & 354410,9 & 16,8 \\
\hline Importações do $\mathrm{N}$ & 497,1 & 9,4 & 4767,3 & 5,0 & 204402,0 & 9,7 \\
\hline Importações do NE & 482,3 & 9,1 & 9501,9 & 10,0 & 179817,5 & 8 , \\
\hline Importações do $\mathrm{CO}$ & 147,5 & 2,8 & 3726,8 & 3,9 & 45382,4 & 2,1 \\
\hline Importações do SE & 3982,3 & 75,0 & 67984,1 & 71,9 & 1330256,0 & 62,9 \\
\hline Importações / montante & & 19,8 & & 21,4 & & 19,8 \\
\hline II - Produção Agropecuária (PA) & 36113,4 & & 571822,2 & & 15754846,3 & \\
\hline Total de exportaçōes - PA & 12295,9 & 100,0 & 199401,5 & 100,0 & 4848837,7 & 100 \\
\hline exportações para o Exterior & 1544,8 & 12,6 & 14192,1 & 7,1 & 272155,8 & 5 \\
\hline Total de exportações DI & 8255,5 & 67,1 & 122990,0 & 61,7 & 3293549,5 & 67,9 \\
\hline exportações DI para $\mathrm{N}$ & 12,0 & 0,1 & 170,2 & 0,1 & 6310,6 & 0 \\
\hline exportações DI para NE & 539,3 & 4,4 & 5524,2 & 2,8 & 162144,4 & 3 \\
\hline exportações DI para CO & 267,1 & 2,2 & 3557,1 & 1,8 & 134416,9 & 2 \\
\hline exportações DI para SE & 7437,0 & 60,5 & 113738,5 & 57,0 & 2990677,6 & 61,7 \\
\hline Total de exportações DF & 2495,5 & 20,3 & 62219,4 & 31,2 & 1283132,4 & 26 \\
\hline exportações DF para $N$ & 32,3 & 0,3 & 992,6 & 0,5 & 18828,6 & 0 \\
\hline exportações DF para NE & 178,6 & 1,5 & 4932,9 & 2,5 & 96228,9 & 2 \\
\hline exportaçōes DF para CO & 12,9 & 0,1 & 353,0 & 0,2 & 8009,0 & 0 \\
\hline exportações DF para SE & 2271,7 & 18,5 & 55940,9 & 28,1 & 1160066,0 & 23,9 \\
\hline Exportaçōes / PA & & 34,0 & & 34,9 & & 30 \\
\hline III - Jusante & 81396,1 & & 1757415,8 & & 26702872,7 & \\
\hline Produção Agroindustrial (PAI) & 30393,3 & & 601142,5 & & 10564467,7 & \\
\hline Total de exportações - PAI & 16642,0 & 100,0 & 283316,4 & 100,0 & 4916650,3 & 100 \\
\hline exportações para o Exterior & 4727,0 & 28,4 & 53124,2 & 18,8 & 1200770,0 & 24 \\
\hline Total de exportações DI & 3199,8 & 19,2 & 64864,0 & 22,9 & 1112299,7 & 22 \\
\hline exportaçōes DI para $\mathrm{N}$ & 54,4 & 0,3 & 1253,3 & 0,4 & 23485,7 & 0 \\
\hline exportações DI para NE & 380,8 & 2,3 & 6557,1 & 2,3 & 111779,0 & 2 \\
\hline exportaçōes DI para CO & 98,5 & 0,6 & 2149,8 & 0,8 & 43710,7 & 0 \\
\hline exportações DI para SE & 2665,9 & 16,0 & 54903,8 & 19,4 & 933324,3 & 19 \\
\hline Total de exportações DF & 8715,2 & 52,4 & 165328,3 & 58,4 & 2603580,6 & 53 \\
\hline exportações DF para $N$ & 379,7 & 2,3 & 9144,4 & 3,2 & 120116,0 & 2 \\
\hline exportações DF para NE & 1430,2 & 8,6 & 29573,7 & 10,4 & 450429,0 & 9 \\
\hline exportações DF para $\mathrm{CO}$ & 236,5 & 1,4 & 5195,6 & 1,8 & 76771,6 & 1 \\
\hline exportações DF para SE & 6668,8 & 40,1 & 121414,6 & 42,9 & 1956263,9 & 39 \\
\hline Exportações / PAI & & 54,8 & & 47,1 & & 46 \\
\hline Total de exportações (PA + PAI) & 28937,9 & & 482718,0 & & 9765488,0 & \\
\hline AGRONEGÓCIO & 144332,2 & & 2772138,6 & & 53149945,6 & \\
\hline Exportações Totais / Agronegócio & & 20,0 & & 17,4 & & 18 \\
\hline PIB regional & 214875,3 & & 5161624,9 & & 101174580,6 & \\
\hline Exportações Totais / PIB & & 13,5 & & 9,4 & & 9 \\
\hline Agronegócio / PIB regional & & 67,2 & & 53,7 & & 5 \\
\hline
\end{tabular}

Fonte: Resultados da pesquisa. Obs.: Os valores são indicados em moeda corrente. 


\subsection{Considerações finais}

Uma característica do comércio exterior brasileiro, desde 1970, tem sido o crescimento absoluto das exportações de todas as regiões. Apesar disso, as regiões Sudeste e Sul continuaram detendo mais de $80,0 \%$ das exportações (tabela 7.1). Paralelamente, o grande avanço da infra-estrutura na década de 70, a expansão da economia, a existência de incentivos fiscais e a diversificação da produção serviram para ampliar os fluxos comerciais inter-regionais. Nesse contexto é que situa-se a análise referente aos fluxos inter-regionais e internacionais do agronegócio brasileiro desenvolvida neste capítulo.

Analisando-se os fluxos interregionais do agronegócio do Brasil pode-se determinar as suas principais características:

a) As exportações do agronegócio são menos concentradas quando comparadas com o padrão de distribuição espacial das exportações totais da economia brasileira;

b) Dentro das regiões, as exportações do agronegócio são mais importantes para as regiões periféricas do Brasil.

A composição das exportações brasileiras para o ano de 1995, segundo os principais produtos, pode ser observada na tabela 7.9. Considerando apenas os setores componentes do agronegócio, pode-se chegar a uma participação de $28,2 \%$ no total exportado pelo Brasil em 1995. Lembrando que a produção de celulose e papel não é considerada como um segmento do agronegócio nessa pesquisa.

Pela tabela 7.9 percebe-se, também, que os produtos que constituem o agronegócio são encontrados entre os produtos básicos (soja, café, fumo, carnes, etc.); semimanufaturados (couros e peles, óleo de soja, etc.); e manufaturados (suco de laranja, café solúvel, etc.); demonstrando, uma vez mais, o poder de encadeamento do setor de agronegócio dentro da economia do país. 
Tabela 7.9: Brasil - Exportação - Principais produtos - 1995.

\begin{tabular}{|c|c|c|}
\hline & $\begin{array}{c}\text { Valor } \\
\text { (US\$ milhões) }\end{array}$ & Percentagem \\
\hline TOTAL & 45680 & \\
\hline BÁSICOS & 10969 & 100,00 \\
\hline Minérios de ferro & 2548 & 23,23 \\
\hline Farelo de soja & 1997 & 18,21 \\
\hline Café em grão & 1970 & 17,96 \\
\hline fumo em folhas & 769 & 7,01 \\
\hline soja em grão & 770 & 7,02 \\
\hline Carne de frango & 637 & 5,81 \\
\hline Açúcar demerara & 408 & 3,72 \\
\hline Farelo de polpa cítrica & 107 & 0,98 \\
\hline Carne de suíno & 84 & 0,77 \\
\hline SEMIMANUFATURADOS & 9146 & 100,00 \\
\hline Celulose & 1447 & 15,82 \\
\hline Semimanufaturados de ferro/aço & 1369 & 14,97 \\
\hline Alumínio, em bruto & 1215 & 13,28 \\
\hline Açúcar cristal & 1042 & 11,39 \\
\hline Óleo de soja, em bruto & 1031 & 11,27 \\
\hline Couros e peles & 566 & 6,19 \\
\hline Ferros ligas & 411 & 4,49 \\
\hline Ouro para uso não monetário & 358 & 3,91 \\
\hline Manteiga, gordura e óleo de cacau & 65 & 0,71 \\
\hline MANUFATURADOS & 25565 & 100,00 \\
\hline Calçados & 1499 & 5,86 \\
\hline Autopeças & 1209 & 4,73 \\
\hline Suco de laranja & 1105 & 4,32 \\
\hline Motores de pistão & 923 & 3,61 \\
\hline Café solúvel & 456 & 1,78 \\
\hline Papel de imprensa & 428 & 1,67 \\
\hline Automóveis de passageiros & 427 & 1,67 \\
\hline Cigarros & 402 & 1,57 \\
\hline Papel para imprimir & 342 & 1,34 \\
\hline Fio-máquina & 279 & 1,09 \\
\hline Aviões & 182 & 0,71 \\
\hline Computadores & 177 & 0.69 \\
\hline
\end{tabular}

Fonte: Siscomex, 1999.

A evidência de que as exportações do agronegócio são menos concentradas que as exportações do conjunto da economia brasileira é facilmente verificada analisando-se as figuras 7.1 e 7.2. A primeira apresenta a divisão espacial do valor de todas as exportações realizadas pela economia do país, enquanto a figura 7.2 apresenta a participação das regiões no valor total exportado pelo agronegócio do Brasil. 
Comparando as figuras percebe-se que as regiões Sudeste e Sul dominam as exportações tanto no geral como apenas no agronegócio; porém a magnitude da concentração é maior quando observa-se a economia como um todo. A diferença varia de $11,0 \%$ a $18,0 \%$ no período analisada; pois as duas regiões em conjunto concentram 86,1\% do total exportado pelo Brasil em 1985, 82,7\% em 1990 e 83,3\% em 1995; enquanto que as mesmas participações nas exportações do agronegócio são, respectivamente, $71,7 \%, 64,9 \%$ e $71,1 \%$.

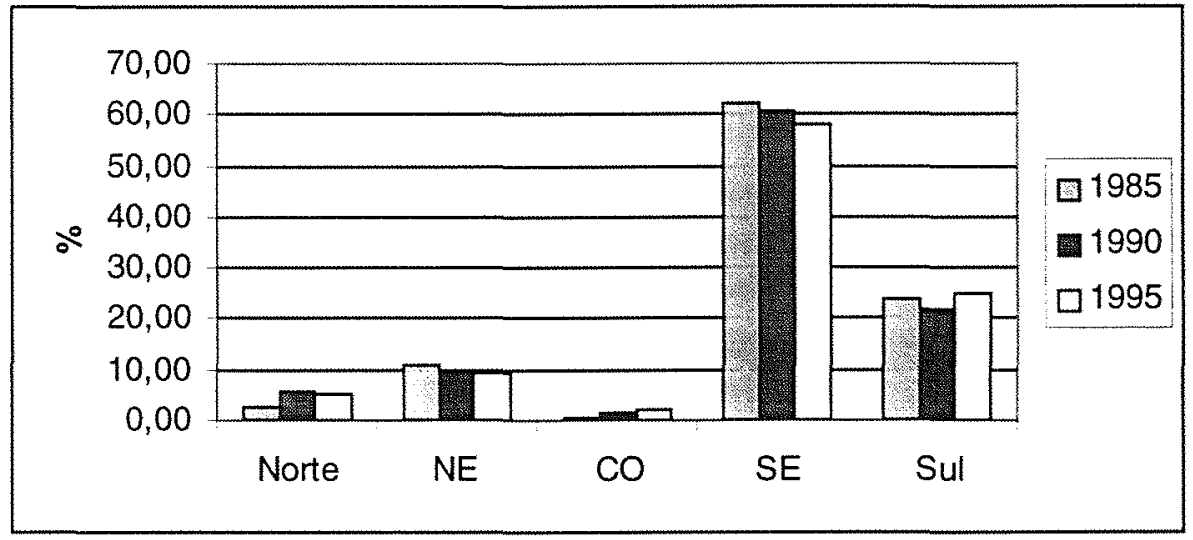

Fonte: Resultados da pesquisa.

Figura 7.1: Participação das regiões no valor total exportado pela economia brasileira, 1985, 1990 e 1995, em percentagem

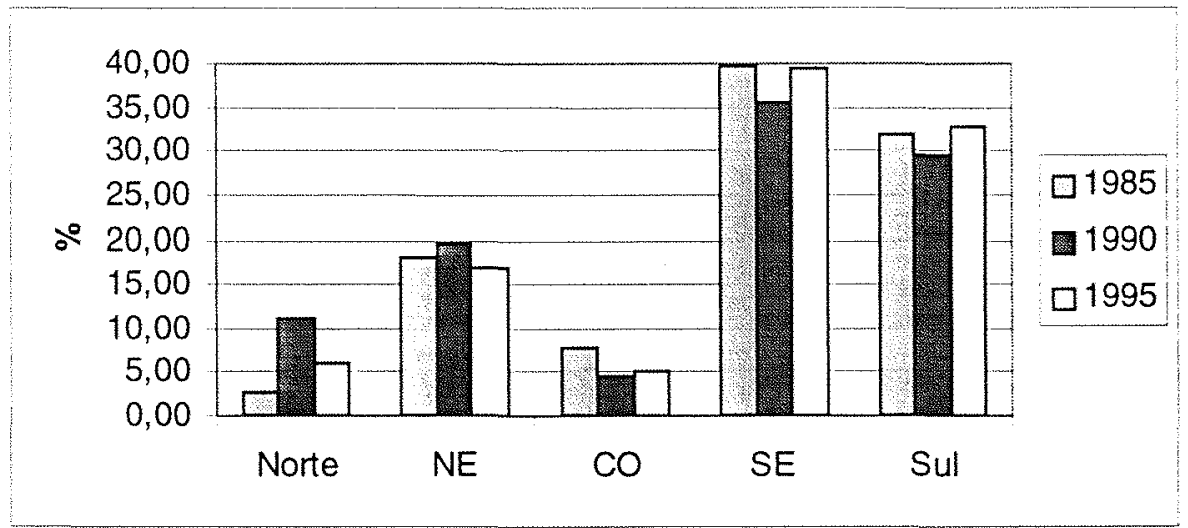

Fonte: Resultados da pesquisa.

Figura 7.2: Participação das regiões no valor total exportado pelo agronegócio brasileiro, 1985, 1990 e 1995, em percentagem 
Este resultado deve-se ao fato de que o agronegócio é constituído, em sua maioria, por produtos das classes básica e semimanufaturada (tabela 7.9), as quais apresentam uma menor concentração em suas exportações, como vê-se pela figura 7.2.

A figura 7.3 confirma a segunda característica das exportações do agronegócio brasileiro, ou seja, o fato da participação das exportações no valor total do agronegócio ser de grande importância para as regiões Norte e Centro-Oeste. Este fato é confirmado pela tabela 7.2 que demonstra o aumento da participação dessas regiões nas exportações de produtos básicos e semimanufaturados. $O$ fato das outras regiões apresentarem uma relação baixa entre o valor exportado e o produzido, deve-se, provavelmente, ao forte mercado consumidor existente nessas regiões do país.

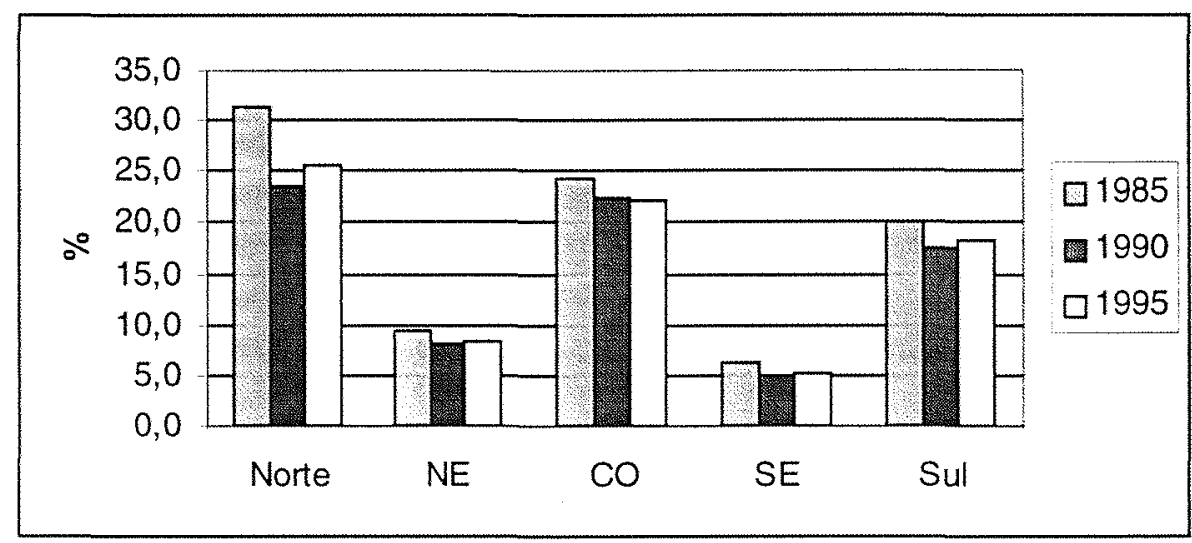

Fonte: Resultados da pesquisa.

Figura 7.3: Parcela do valor total da produção do agronegócio que é exportado (para as demais regiões e para o exterior), 1985, 1990 e 1995, em percentagem. 


\section{CONCLUSÕES}

A preocupação básica desta pesquisa foi relacionar as diferenças preexistentes entre as regiões brasileiras e as que surgiram na consolidação e estruturação do agronegócio nessas regiões. Os resultados foram satisfatórios, visto que não apenas as hipóteses se confirmaram, mas, também, todos os questionamentos feitos na introdução da pesquisa foram respondidos com grande nível de detalhamento a partir dos resultados obtidos.

Foram apresentados, nesta tese, três capítulos de resultados, a saber, os capítulos 5, 6 e 7; e, em todos, foi elaborado um tópico conclusivo denominado "Considerações finais", em que foram exploradas detalhadamente as principais conclusões que surgiram dos resultados apresentados. Falta, entretanto, realizar uma análise conjunta desses três capítulos de resultados, o que possibilitará uma detalhada caracterização do agronegócio das regiões do Brasil. Serão abordados, também, os problemas enfrentados no desenvolvimento da pesquisa e algumas propostas para pesquisas futuras.

A partir das informações sobre a participação das macrorregiões na constituição do agronegócio brasileiro e da composição do agronegócio dentro das regiões, chegouse às seguintes conclusões:

a) houve uma desconcentração do agronegócio total e de seus segmentos (agregados I, II e III) entre 1985 e 1995;

b) houve diminuição generalizada da relação agronegócio/PIB, tanto para o Brasil quanto em suas macrorregiões, entre 1985 e 1995; 
c) observam-se grandes diferenças na composição do agronegócio entre as regiões do Brasil.

A região Sudeste, que detinha $46 \%$ do agronegócio em 1985, passou a concentrar 44,2\% em 1990 e 41,2\% em 1995; já na região Sul, essas mesmas participações eram, respectivamente, $29,2 \%, 28,2 \%$ e 30,0\%; no Nordeste, $14,8 \%$, 15,4\% e 13,6\%; no Centro-Oeste, $6,6 \%, 7,2 \%$ e 10,4\%; e, na região Norte, $3,5 \%, 5 \%$ e $4,2 \%$. Percebe-se uma contínua diminuição da parcela da região Sudeste no valor total do agronegócio do país a favor de um aumento das participações das regiões Norte, Sul e Centro-Oeste, principalmente desta última.

A produção agroindustrial brasileira também apresentou alteração na distribuição do valor de sua produção entre as regiões brasileiras. A tendência indica diminuição da parcela do Sudeste em favor das regiões Norte, Centro-Oeste e Sul, sendo que a participação do Nordeste pouco se alterou no período analisado. Percebe-se, portanto, uma desconcentração da produção agroindustrial brasileira. O segmento, porém, continua situado nas regiões Sudeste e Sul, sendo que, em 1995, 80\% do valor da produção agroindustrial ainda estavam nessas duas regiões do Brasil.

Quanto à participação do agronegócio na composição do Produto Interno Bruto das regiões brasileiras e também do Brasil, no período 1985/1990, verifica-se que houve diminuição da importância do valor da atividade na constituição do valor total de bens e serviços produzidos no território brasileiro e nas regiões do país.

A maior diminuição aconteceu na região Sul, que apresentava uma relação agronegócio/PIB de 67,2\% em 1985, essa relação diminuiu para 53,7\% em 1990 e para 52,5\% em 1995; enquanto na região Centro-Oeste, essas mesmas relações foram, respectivamente, $48,6 \%, 36,6 \%$ e $38,1 \%$; no Nordeste, $37,9 \%, 31,0 \%$ e $28,3 \%$; na região Norte, $30,1 \%, 31,2 \%$ e $26,2 \%$; e na região Sudeste, $30,4 \%, 23,9 \%$ e $23,2 \%$. O total para o Brasil também seguiu a mesma tendência de diminuição da relação agronegócio/PIB, apresentando participação de 38,6\% em 1985, 31,0\% em 1990 e 30,4\% em 1995. 
Foi realizada uma análise sobre a constituição do agronegócio das regiões brasileiras, procurando identificar o nível de importância de cada segmento no processo de agregação de valor realizado pelo complexo agroindustrial ou agronegócio nas regiões, chegando-se às seguintes observações:

a) percebe-se uma grande heterogeneidade estrutural no agronegócio brasileiro, variando de região para região;

b) convivem níveis diferentes de desenvolvimento inter e intrarregional no agronegócio do país, principalmente quando se comparam os segmentos de processamento, armazenamento e distribuição final de produtos agropecuários (jusante do agronegócio).

Utilizando dos parâmetros de Malassis (1969), o agronegócio das regiões Sudeste e Sul apresentam configuração com características de uma economia alimentar industrializada; já para a região Centro-Oeste e Norte, a classificação seria de uma economia pré-industrial; e a região Nordeste teria uma economia alimentar em vias de industrialização.

Analisando os fluxos inter-regionais do agronegócio do Brasil, pode-se determinar suas principais características:

a) as exportações do agronegócio são menos concentradas quando comparadas com o padrão de distribuição espacial das exportações totais da economia brasileira;

b) dentro das regiões, as exportações do agronegócio são mais importantes para as regiões periféricas do Brasil.

As regiões Sudeste e Sul dominam as exportações, tanto no geral como apenas no agronegócio, mas a magnitude da concentração é maior quando se observa a economia como um todo. A diferença varia de $11 \%$ a $18 \%$ no período analisado, pois as duas regiões, em conjunto, concentravam $86,1 \%$ do total exportado pelo Brasil em 1985, $82,7 \%$ em 1990 e $83,3 \%$ em 1995, enquanto que as mesmas participações nas exportações do agronegócio eram, respectivamente, $71,7 \%, 64,9 \%$ e $71,1 \%$. 
O agronegócio da região Norte é relativamente o que apresenta a menor participação na composição do total desse setor para o Brasil. Este, porém, é importante na produção de bens e serviços da região, apesar de apresentar tendência de diminuição de importância na economia regional. Sua principal característica é agregar pouco valor ao produto agropecuário, pois seu agregado III é pouco representativo, apesar de sua agroindústria ter boa participação. O fator limitante estaria, então, no segmento de distribuição final do complexo agroindustrial da região. As exportações do agronegócio da região são importantes, já que representavam $1 / 4$ do valor total produzido pelo setor e quase $7 \%$ do PIB regional em 1995, sendo que a maior parte de suas vendas tem como destino a região Sudeste do país.

A região Nordeste apresenta um setor de agronegócio em fase de transição. Este é importante para a região, participando, em média, no período analisado, com mais de $1 / 3$ do valor total de bens e serviços produzidos na região. A principal característica do agronegócio da região Nordeste é apresentar uma agroindústria pouco representativa, o que dificulta o processo de agregação de valor. As exportações do setor são mais importantes, relativamente ao total exportado pelo Brasil, do que o total de exportações da região, ou seja, enquanto estas exportações representam menos de $10 \%$ do total exportado pelo país, as exportações do agronegócio dessa região representam quase $17 \%$ do total exportado pelo agronegócio brasileiro. Do total produzido pelo agronegócio da região Nordeste, $8,4 \%$ foram exportados em 1995 , tendo como principal comprador os países do Exterior.

A região Centro-Oeste é tradicional fornecedora de matéria-prima de origem agrícola para as outras regiões do Brasil. Isto levou seu setor de agronegócio a ser pouco desenvolvido no sentido de agregar valor aos produtos agropecuários. Entretanto, percebe-se que existe tendência de aumento da participação dessa região na composição do agronegócio do país em todos os seus segmentos. A importância do agronegócio para a região é muito grande, com uma participação média na composição do PIB regional de $41 \%$ no período analisado. A principal característica desse setor, na região Centro-Oeste, são a grande participação do segmento de produção agropecuária em sua composição e a 
pequena participação do agregado III (a menor do país). As exportações representam 1/5 do valor total produzido pelo setor e $8 \%$ do PIB da região é composto pelas exportações do agronegócio.

Da mesma forma com que concentra a maior parte do PIB total do Brasil, a região Sudeste também detém a maior parcela do agronegócio do país, $44 \%$ em média. Mas essa parcela diminuiu durante o período de análise da pesquisa, refletindo-se em todos os segmentos do setor. A participação do agronegócio na composição do PIB da região Sudeste foi a menor, entre todas as regiões do país, em 1995. A principal característica do agronegócio da região é a grande participação do agregado III na composição do setor, mais de $60 \%$, devido, principalmente, ao segmento de distribuição final (transporte e comércio). Em 1995, o valor das exportações representou pouco mais de 5\% do valor total produzido pelo setor, demostrando a importância do mercado interno da região. Isso também é confirmado pelas exportações do agronegócio em relação ao PIB da região, que totalizaram apenas $1 \%$.

A participação da região Sul na composição do agronegócio brasileiro aumentou no período analisado, demostrando a importância dessa região na produção agropecuária e agroindustrial do país. Praticamente 1/3 do valor total do agronegócio do Brasil é gerado nessa região. Essa importância reflete-se na parcela do PIB regional que cabe ao agronegócio, pouco mais de 50\%. Esta é a principal característica do agronegócio da região Sul, ou seja, sua importância para a economia regional, a maior do país. As exportações do setor representaram mais de $18 \%$ do valor total da produção em 1995, sendo que em relação ao PIB da região, essas exportações contribuíram com quase $10 \%$ do total de bens e serviços.

O processo de desconcentração inter-regional que está acontecendo no agronegócio brasileiro terá implicações importantes no processo de desenvolvimento das regiões, principalmente a partir do momento que as regiões Norte, Nordeste e CentroOeste desenvolverem o setor de processamento agroindustrial e passarem a agregar mais valor a seus produtos agropecuários. 
O principal problema enfrentado na execução dessa pesquisa foi, sem dúvida, a dificuldade de obtenção de informações confiáveis sobre algumas estatísticas econômicas das regiões do Brasil. Esse problema também foi enfrentado por Cano (1998), que reclamou da seguinte forma: “... o sistema estatistico nacional, a partir de 1990, sofreu profunda deterioração institucional, política, financeira e de seus recursos humanos,..., não realizando nenhum Censo Econômico após 1985. Isto, obviamente, repercute diretamente sobre as Contas Nacionais, tornando mais precários os dados regionalizados...". Além da falta de estatísticas, também são poucos os estudos que caracterizam a economia e os segmentos do agronegócio das regiões, principalmente de Centro-Oeste, Norte e Nordeste. Este fato impossibilitou que os resultados desta pesquisa fossem complementados com outros estudos, o que facilitaria a interpretação de alguns resultados.

Obviamente, o presente estudo apresenta limitações. Portanto, pode-se delinear algumas propostas de trabalhos futuros que venham complementar esta pesquisa e trazer mais informações importantes sobre o agronegócio das regiões do Brasil. Neste sentido, do ponto de vista teórico, seria interessante realizar uma crítica às idéias de Malassis (1969), na intenção de avançar nessa teoria que relaciona a constituição do agronegócio com o nível de evolução de uma economia, considerando, por exemplo, as diferenças de importância de cada região na composição do agronegócio de uma nação, e as diferenças na importância do agronegócio para a economia da região. Outra linha de pesquisa que pode surgir é o aprofundamento do conhecimento do agronegócio das regiões, realizando-se um estudo em nível de unidades de federação, pois a desagregação possibilitará analisar os resultados com mais detalhamento e, consequentemente, mais qualidade. 


\section{BIBLIOGRAFIA}

ARAÚJO, N.B.; et al. Complexo agroindustrial: o "agribusiness"brasileiro. São Paulo: Agroceres, 1990. 238p.

ARAÚJO, T.B. de Nordeste, Nordestes: que Nordeste? In: AFFONSO, R.B.A.; SILVA, P.L.B. (org.) Desigualdades regionais e desenvolvimento - (Série Federalismo no Brasil). São Paulo: FUNDAP: Editora da UNESP, 1995. p.125-156.

BACHA, C.J.C.; ROCHA, M.T. Desempenho da agropecuária brasileira no período de 1987 a 1998. In: Congresso Brasileiro de Economia e Sociologia Rural, 37., Foz do Iguaçu, 1999. Anais. Brasília:SOBER, 1999 [CD-ROM].

BACHARACH, M. Biproportional matrices and input-output change. Cambridge: Cambridge University Press, 1970.

BAER, W. A economia brasileira. São Paulo: Nobel, 1986. 416p.

BANDEIRA, P.S. A economia da região Sul. In: AFFONSO, R.B.A.; SILVA, P.L.B. (org.) Desigualdades regionais e desenvolvimento - (Série Federalismo no Brasil). São Paulo: FUNDAP: Editora da UNESP, 1995. p.225-251.

BARRY, P.J. et al. Vertical coordination, financial structure and the changing theory of the firm. American Journal of Agricultural Economics, v.74, n. 5, p. 1219-25, 1992.

BÊRNI, D. Descrição e previsão da mudança estrutural no Brasil entre 1959 e o ano 2000: insumo-produto, método Delphi e método RAS. In: MONTOYA, M.A. (org) Relações intersetoriais do Mercosul e da economia brasileira: uma abordagem de equilíbrio geral do tipo insumo-produto. Passo fundo: Ediupf, 1998. Cap. 8.

BERTERO, C.O. Considerações finais. Revista de Administração de Empresas, v.18, n.3, p.101-105, jul/set 1978.

BRASI, Congresso Nacional, Comissão Especial Mista. Desequilíbrio econômico inter-regional brasileiro. Relatório Final. Brasília, 1993. v.1, 110p. 
BUARQUE, S.C.; LOPES, A.D.; ROSA, T.C. Integração fragmentada e crescimento da fronteira Norte. In: AFFONSO, R.B.A.; SILVA, P.L.B. (org.) Desigualdades regionais e desenvolvimento - (Série Federalismo no Brasil). São Paulo: FUNDAP: Editora da UNESP, 1995. p.93-123.

CANO, W. Desequilíbrios regionais e concentração industrial no Brasil-1930/1995. 2 ed. rev. ampl. Campinas:UNICAMP.IE, 1998. 421 p. (coleção 30 anos de economia - Unicamp, 2).

CANO, W. Desequilíbrios regionais e concentração industrial no Brasil-1930/1970, Campinas, DEPE/IFCH/UNICAMP, 1981, 4v., 447p. (Tese de Livre-Docência).

CEBRAP Concentração e centralização de capitais na indústria de alimentos brasileira. São Paulo: Centro Brasileiro de Análise e Planejamento, 1997. 105p. (Relatório Final de Pesquisa).

CONSIDERA, C.M.; MEDINA, M.H. PIB por unidade da federação: valores correntes e constantes. Texto para discussão n.610. Rio de Janeiro:IPEA, 1998. 32p. (acompanha disquete de dados).

CROCOMO, F.C. Análise das relações inter-regionais e intersetoriais na economia brasileira em 1985: uma aplicação de insumo-produto. Piracicaba, 1998, 179p. Tese (doutorado) - Escola Superior de Agricultura "Luiz de Queiroz", Universidade de São Paulo.

CROCOMO, F.C.; GUILHOTO, J.J.M. As relações inter-regionais e intersetoriais das macrorregiões da economia brasileira em 1985. In: MONTOYA, M.A. (org) Relações intersetoriais do Mercosul e da economia brasileira: uma abordagem de equilíbrio geral do tipo insumo-produto. Passo fundo: Ediupf, 1998. Cap. 7.

DAVIS, J.H.; GOLDBERG, R.A. A concept of agribusiness. Boston: Harvard Graduate School of Business Administration, 1957. 152p.

DELGADO, G. Capital financeiro e agricultura no Brasil. São Paulo: Ícone, 1985. $240 \mathrm{p}$.

DINIZ, C.C.; SANTOS, F.B.T. Sudeste: heterogeneidade estrutural e perspectivas. In: AFFONSO, R.B.A.; SILVA, P.L.B. (org.) Desigualdades regionais e desenvolvimento - (Série Federalismo no Brasil). São Paulo: FUNDAP: Editora da UNESP, 1995. p.195-223. 
DORFMAN, $R$. The nature and significance of input-output. The review of economics and statistics. v.36, 1954, p.212-133.

FARINA, E.M.M.Q. O sistema agroindustrial de alimentos. In: ENCONTRO NACIONAL DE ECONOMIA, 16., Belo Horizonte, 1988. Anais. Rio de Janeiro: ANPEC, 1988. V.3, p.292-315.

FERREIRA $\mathrm{F}^{0}$, J.B.S. Megabrás- um modelo de equilíbrio geral computável aplicado à análise da agricultura brasileira, 1995. 159p. Tese (Doutorado) - Faculdade de Economia, Administração e Contabilidade, Universidade de São Paulo.

FUNDAÇÃO SEADE - Sistema Estadual de Análise de Dados. Agroindústria paulista. São Paulo:SEADE, 1990. 59p. (Coleção Economia Paulista, v.3).

FURTUOSO, M.C.O. O produto interno bruto do complexo agroindustrial brasileiro. Piracicaba, 1998, 277p. Tese (doutorado) - Escola Superior de Agricultura "Luiz de Queiroz", Universidade de São Paulo.

FURTUOSO, M.C.O.; BARROS, G.S.A.C.; GUILHOTO, J.J.M. O produto interno bruto do complexo agroindustrial brasileiro. Revista de Economia e Sociologia Rural, v. 36, n. 3, p. 9-31, Jul/Set 1998.

GALINDO, O.; SANTOS, V.M. Centro-Oeste: evolução recente da economia regional. In: AFFONSO, R.B.A.; SILVA, P.L.B. (org.) Desigualdades regionais e desenvolvimento - (Série Federalismo no Brasil). São Paulo: FUNDAP: Editora da UNESP, 1995. p.157-194.

GALVÃO, A.C.F.; VASCONCELOS, R.R. Política regional à escala sub-regional: uma tipologia territorial como base para um fundo de apoio ao desenvolvimento regional. Texto para discussão n.665 Brasília:IPEA, 1999. 29p.

GUILHOTO, J.J.M. et al Nível de atividade do agronegócio no Brasil. Relatório de Pesquisa. CNA/CEPEA, 1999. Mimeo.

GUIMARÃES NETO, L. Desigualdades regionais e federalismo. In: AFFONSO, R.B.A.; SILVA, P.L.B. (org.) Desigualdades regionais e desenvolvimento - (Série Federalismo no Brasil). São Paulo: FUNDAP: Editora da UNESP, 1995. p.13-59.

GUIMARÃES NETO, L. O grande capital vai à periferia (regiões, conglomerados, grandes empresas e o estado). In: ENCONTRO NACIONAL DE ECONOMIA, 21., Belo Horizonte, 1993. Anais. Rio de Janeiro: ANPEC, 1993. 
HAGUENAUER, 1. et al Estimativas do valor da produção industrial e elaboração de coeficientes de exportações e importação da indústria brasileira (1985/96). Texto para discussão n.563 Brasília:IPEA, 1998. 78p.

HOFFMANN, R. et al Inovações tecnológicas e transformações recentes na agricultura brasileira. Relatório de Pesquisa, Piracicaba: FEALQ, 1985, 4v., 780p.

IBGE Anuário estatístico do Brasil 1997. [CR-ROM]. Rio de Janeiro: IBGE, v.57, 1998

IBGE Matriz de insumo-produto: Brasil - 1995. Rio de Janeiro: IBGE, 1997. 217p.

IBGE Matriz de insumo-produto: Brasil - 1990. Rio de Janeiro: IBGE, 1996.

IBGE Matriz de relações intersetoriais: Brasil-1985. Rio de Janeiro: IBGE, 1995.

IBGE Censo agropecuário: Brasil - 1985. Rio de Janeiro: IBGE, n.1, 1991. 399p.

IBGE Censo agropecuário: Brasil - 1995-1996. Rio de Janeiro: IBGE, n.1, 1998a. $366 \mathrm{p}$.

IBGE Censos econômicos: Brasil-1985. Rio de Janeiro: IBGE, 1991.

IPEA O Brasil na virada do milênio: trajetória do crescimento e desafios do desenvolvimento. Brasília:IPEA, 1997, v.2, 202p.

ISARD, W. Interregional and regional input-ouput analysis: a model of a space economy. Review of Economics and Statistics, v.33, n.4, p.318-328, 1951.

ISARD, W.; KUENNE, R.E. The impact of steel upon the Greater New YorkPhiladelphia region. Review of Economics and Statistics, v.35, n.4, p.289-301, 1953.

KAGEYAMA, A.; GRAZIANO DA SILVA, J. Do complexo rural aos complexos agroindustriais. In: GRAZIANO DA SILVA, J. A nova dinâmica da agricultura brasileira. Campinas: UNICAMP.IE, 1996. Cap.1, p.1-40.

KAGEYAMA, A. et al. O novo padrão agrícola brasileiro: do complexo rural aos complexos agroindustriais. In: DELGADO, G. et al. (org.) Agricultura e políticas públicas. Brasília: IPEA, 1990. (relatório, n.127).

LAUSCHNER, R. Agribusiness, cooperativa e produtor rural. São Leopoldo: UNISINOS, 1995. 296p. $2^{\circ}$ ed. 
LEONTIEF, W. Quantitative input-output relations in the economic system of the United States. Review of economic and statistics. v.18, p.105-125, 1936.

LEONTIEF, W. The structure of american economy, 1919-1929. Harvard University Press, 1941.

LEONTIEF, W. A economia do insumo-produto. São Paulo: Ed. Fundo de Cultura, $1983,227 \mathrm{p}$.

MALASSIS, L. La structure et l'évolution du complexe agri-industriel d'aprés la comptabilité nationale française. Économies et Sociétés. Paris, v.3, n.9, p1667-1687, set. 1969.

MARTINE, G.A evolução espacial da população brasileira. In: AFFONSO, R.B.A.; SILVA, P.L.B. (org.) Desigualdades regionais e desenvolvimento - (Série Federalismo no Brasil). São Paulo: FUNDAP: Editora da UNESP, 1995. p.61-91.

MARTINE, G.; DINIZ, C.C. Concentração econômica e demográfica no Brasil: recente inversão do padrão histórico. In: Revista de Economia Política. v. 11, n.3, p. 121134. jul/set 1991.

MILLER, R.E. Regional and interregional input-output analysis. In: ISARD, W. et al. Methods of interregional and regional analysis. Vermont:Asghate, 1998. Cap.3, p.41-133.

MILER, R.E. The impact of the aluminium industry on the Pacific Northwets: a regional inpu-output analysis. Review of economic and statistics. v.39, n.2, p.200$209,1957$.

MILLER, R.E.; BLAIR, P.D. Input-output analysis: foundations and extensions. Englewood Cliffs: Prentice-Hall, 1985. 464p.

MÜLLER, G. Complexo agroindustrial e modernização agrária. São Paulo: Hucitec, 1989. $148 \mathrm{p}$.

MONTOYA, M.A.; GUILHOTO, J.J.M. Mudança estrutural no agronegócio brasileiro e suas implicações na agricultura familiar. In: TEDESCO, J.C. (org) Agricultura familiar: realidades e perspectivas. Passo Fundo: Ediupf, 1999. (no prelo).

MONTOYA, M.A. A matriz insumo-produto internacional do Mercosul em 1990: a desigualdade regional e o impacto intersetorial co comércio inter-regional. Piracicaba, 1998, 217p. Tese (doutorado) - Escola Superior de Agricultura "Luiz de Queiroz", Universidade de São Paulo. 
NAÇÕES UNIDAS. Problemas que plantean los quadros y el analisis insumoproduto. N.14, serie F, New York, 1966.

PARRÉ, J.L. Proposta da utilização de um modelo de dois setores para análise da geração de excedentes na agroindústria brasileira. Texto para discussão n.10/1998. FEA/CEA/Universidade de Passo Fundo, 1998. 24p.

PARRÉ, J.L.; ARAÚJO, P.F.C. Estudo das relações de troca da agricultura paulista. In: Congresso Brasileiro de Economia e Sociologia Rural, 35., Natal, 1997. Anais. Brasília:SOBER, 1997. [CD-ROM].

RATTNER, H. Aspectos econômicos e tecnológicos da indústria de alimentos brasileira. Revista de Administração de Empresas, v.18, n.3, p.17-36, jul/set 1978.

SILVA, A.B.O; CONSIDERA, C.M.; MAGALHÃES, K.M.M.; RAMOS, O.R.L. Matriz de insumo-produto do Nordeste - 1980 e 1985..Fortaleza:BNB, 1992.

SILVA, A.B.O; CONSIDERA, C.M.; MAGALHÃES, K.M.M.; BITTENCOURT, S.M. Matriz de insumo-produto do Norte - 1980 e 1985..Belém:SUDAM, 1994. 384p.

SILVEIRA, A.H.P. Uma variante do método biproporcional para a projeção de matrizes de relações intersetoriais na ausência de dados sobre produção intermediária. In: ENCONTRO NACIONAL DE ECONOMIA, 21., Belo Horizonte, 1993. Anais. Rio de Janeiro: ANPEC, 1993. p.199-214.

STREETER, D.H. et al. Information technology, coordination and competitiveness in the food and agribusiness sector. American Journal of Agricultural Economics, v. 73, n. 5, p. 1465-71, 1991.

SUZIGAN, W. Indústria brasileira: origem e desenvolvimento. São Paulo: Brasiliense, 1986. 403p.

TEIXEIRA, J.R.; SILVA, D.C.M. Modernização da matriz de input-output utilizando modelos matemáticos. Revista Brasileira de Economia, v.32, n.1, p. 141-160, jan/mar 1978 .

VICECONTI, P.E.V. O processo de industrialização brasileira. Revista de Administração de Empresas, v.17, n.6, p.33-43, nov/dez 1977.

WILKINSON, J. Competitividade da agroindústria brasileira. Agricultura em São Paulo, v.42, n.1, p.27-56, 1995. 


\section{ANEXO A}

Tabela A. 1: Versão completa da matriz de insumo-produto inter-regional para o Brasil, 1985. Em bilhões de cruzeiros de 1985.

Fonte: dados da pesquisa. 
Mocánica

Matenial de Transporie

Madiera a Mobiliario

Ind. da Borracha

Qulmica

Písticos

ind. Tóxlll
Vestuário Cacados

Pyod. Allmentares

Industrias DNarsa
SIUP Com..

Construçăo $\mathrm{CW}$

Transportes

Servicos

Agropecuáata

Minerais ná Motaticos

Metalurgia

Macanica

Material de Transporte

Madora o Mobilianio

Colutose, Papol o Grat.

Ind. da Borracha

Qulmica

Fafmacdutica

Ind. Táxtil

Prod. Alimertar

SUP Com.

Combructa

Transporio:

Servicos

Agropacuar

Mineràis não Motákicos

Metalurgia

Material Endtrico

Matertal de Transporte

Colutiose, Papel Grat

ind. da Borracha

Quimica

Plasticos

ind. Taxtli

indústrias Diverses

SIUP COM.

Construç äo $\mathrm{CNa}$

Comercbo

Servicos

Agropecuátria

Minstraçáo

Metalurgia

Mecánica

Material Elétrico

Madeira o Mobiliánio

Coluiose. Papol Grá.

Ind. da Borracha

Fulmica

Plásticos

Ynd. Táxtil

Prod. Alimertares

Induistrias Dwersas

SIUP Com.

Construçáo

Transportas

Servicos

Agropecuár

Minerais náo Matabcos

Motalurgia

Material Elétrico

Material de Transoonte

Madeira e Mobitiano

Colubse. Papet

Quimica

Farmacôutica

Plásticos

Vestuatio o Calcadas

industrias Diver

SIUP Com..

Construc ào $\mathrm{C}$

Comercio

Transportas

Serviços

Impostos

Remuneraçdes

V.A. Custo de Falor impostos s/ Atwidad Subsidios a/ Atividado V.A. Proço 8 ásico

Soma Linhas 1 an 22

Soma Linhas 45 a 68

Soma Linhas 67 ? 88

Soma Linhas 67 a 88
Soma Linhas 89 a 110

L $118+L 124$ (Ta 6 or
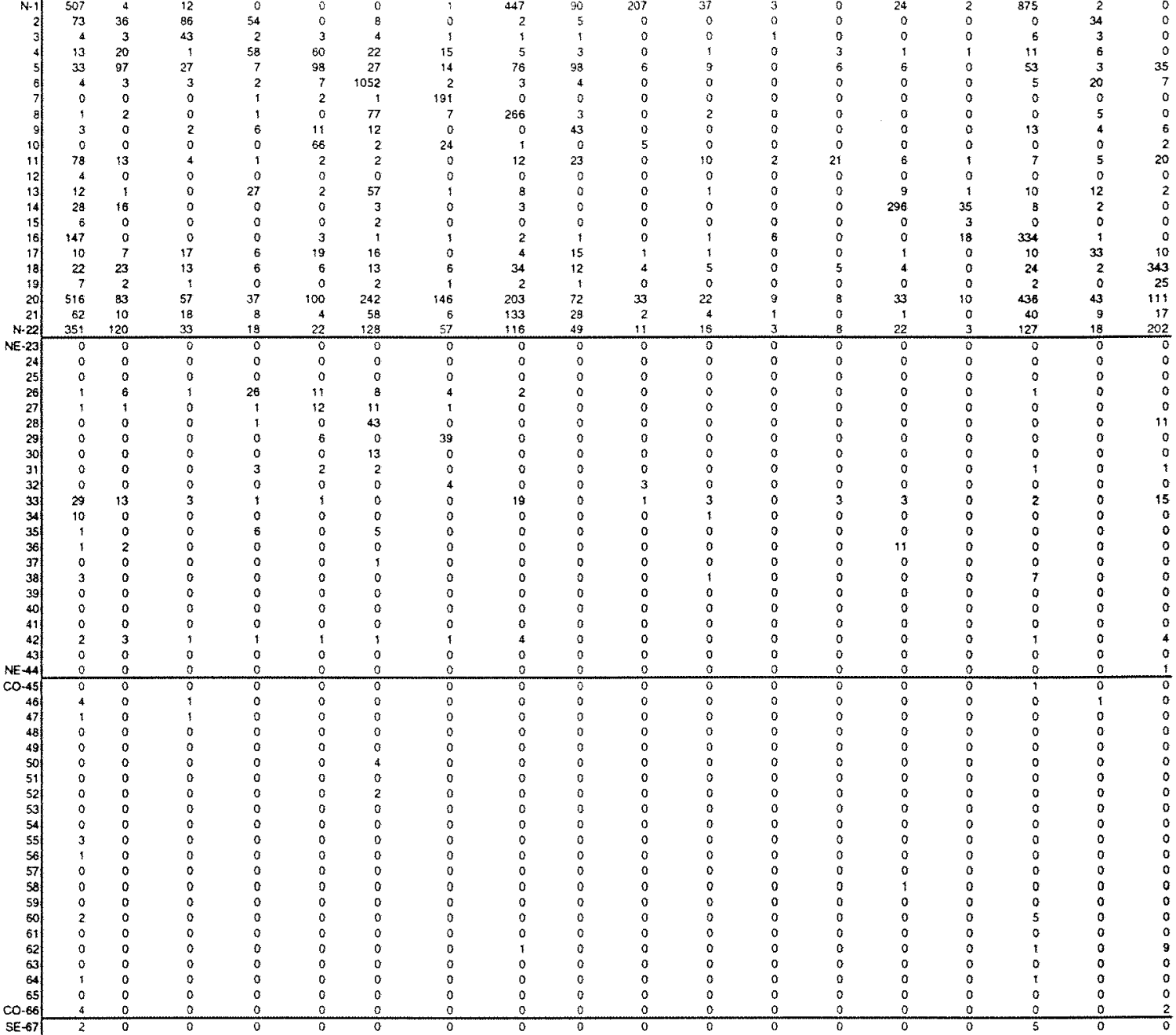

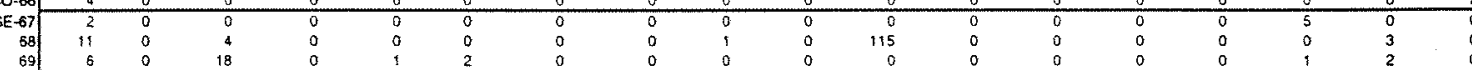
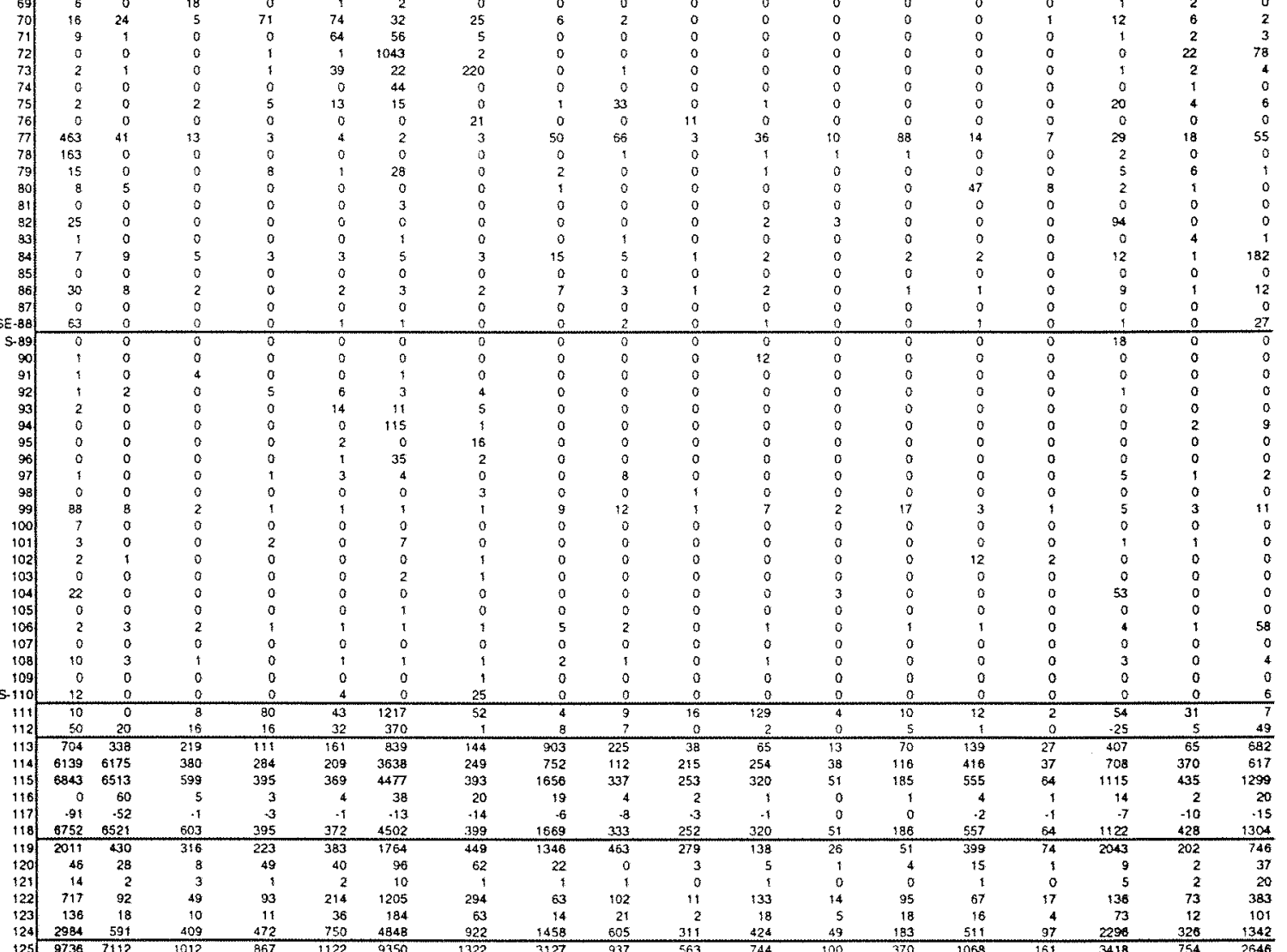
Agropecuáriz

Minera sỏ nóo Metálicos Motaturgia

Macabnica

Menar Transporte Madoira e Mothilianto

Colutiose. Paogl o Grat.

Ind da Borracha

Quirnica

Piasticos

Vestuario Calçados

Prod. Alimentares

Inctistras Oversas

Consinxyso CN

Combreo

Servicos

Agrocecuári

Minera naso Metalicos Motakurgia

Mecánica

Material de Transponto

Madeira e Mobiliário

Colviose, Papel G Gat.

Ind da Borrach

Plasticos

Vestuaño Cakçados

Prod. Almentares

Intustras Dver
SIUP - Com.

Constructo CNA

Comercio

Servicos

Agropecúánita

Mineraçáo

Motakurgta

Mecánica

Malerial de Transporte

Colubses, Papelo Grat.

Ind. da Borracha

Oulmica

Plásticos

Vostuario - Calçado

Prod. Alimentares

Indusarcias DNarsa

Construça Cinl

Comircio

Servicos

Agropecuána

Mineracis náo Matáticos Motalutgia

Mecànica

Matenal Eletrico

Madeir a e Mobiliário

Ind da Borrach

Farmacoutica

Piásticos

Vestuatio Calçados

Piod. Alimentares

Industrias ONorsa

SIUP a Com..

Consiruçás
Comprio

Tiansportes

Agropocuaria

Agropecuaria

Mirerais năo Motálicos

Motalurgia

Mactnica

Material de Transports

Madeira e Mobiltáro

ind da Borracha.

Farmacética

Plastico

Ind Toxtil

Prod. Alimentares

Silue Com.

Constructo $\mathrm{Civ}$

Commerco

Transporias

Importaçoos

imporstos

Remuneracóas:

Excodonto Bruto impostos a / Atividade Subsidios a A Alividado V.A. Proco BAsico

Som Linhas 1 a 22 Sorna Lthhas 23 * 44 Soma Linhas 45 a 66 Soms Linhas $67 * 88$ Soma Limhas 89 a 110 L. $118+1$ i 124 (Tot Gorat
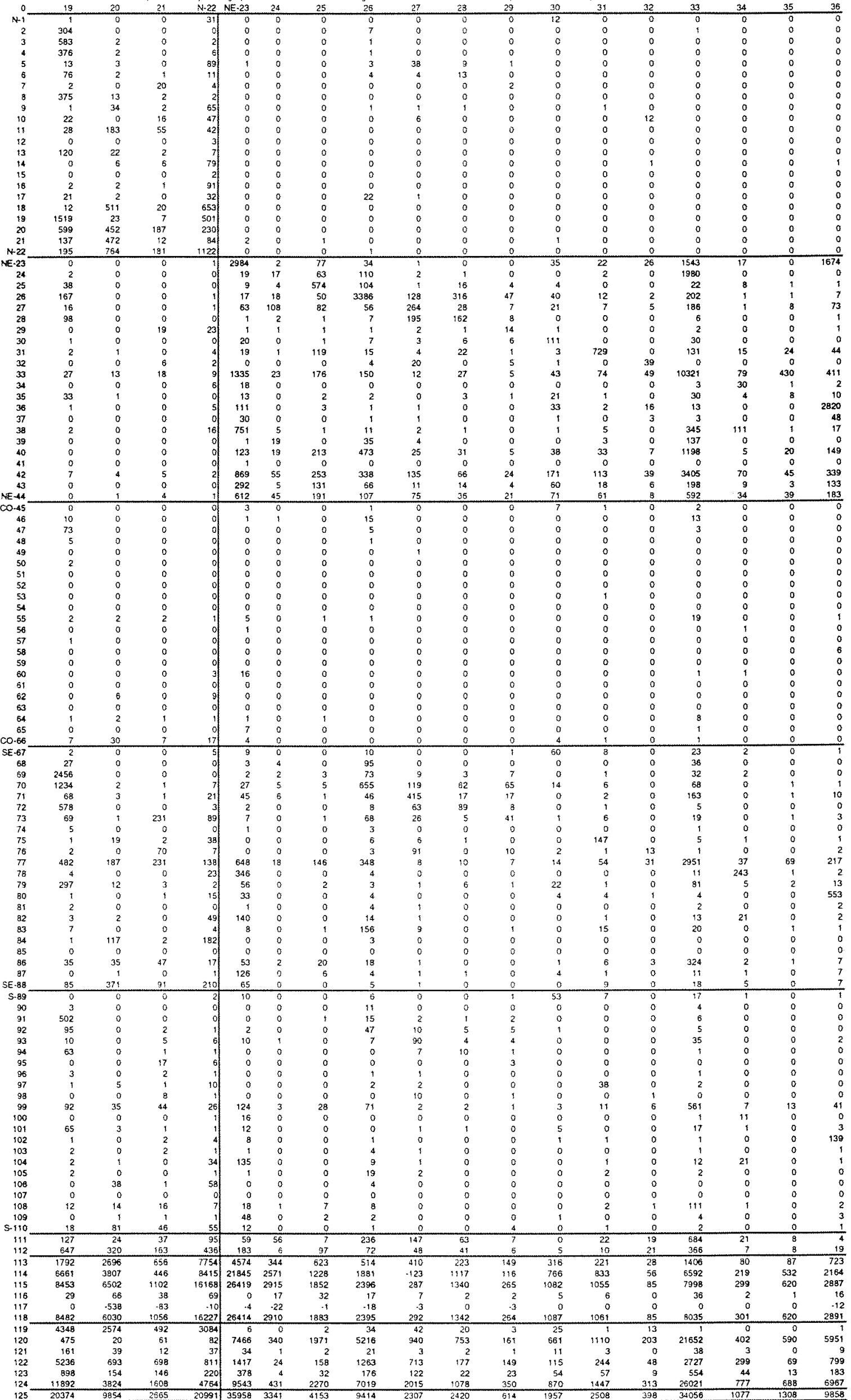
Minerais náo Motálicos

Matalutgia

Macanica

Material de Transpone

Colutose, Papel a Grád.

ind, da Borracha

Qulmica

Pisticticos

Yostuário Calcados

Prod. Alimentares
incoistrias DNefsas

Siup Com.

Construcăo $\mathrm{CN}$

Ir ansportes

Servicos

Agropecuaria
Mineractio

Mineraçắo

Metaturgia

Material Elátrico

Material de Transporte

Madeira o Mobiliário

Ind da Borracha

Gumica

Pilasticos

Vestuatio o Cakacados

Prod. Alimentares

Inchistrias Dingrs
SIUP. Comt.

Construça Civi

Comorcto

It ansportes
Senviços

Agropecuatia

Minerąááa năo Matalicos

Motalurgia

Macancerial Elaticico

Matarial de Transponte

Madelra a Mobillário

Ind da Borracha

Quimica

Plásticos

Ind Toxil

Vostuárb - Cakcados

Prod. Allmentares

SIUP - Com.

Comercio

Transportes

Servicos

Agropecuária

Minerais não Metálicos

Motaurgla

Mecánica

Malerial de Transporte

Madara a Mobiliario

Ind, da Borrache

Quimica

Farmacêu

Ind Taxxtil

Caicados

Prod. Alimentares

industrias Drvart
Siup Com..

Construcão $\mathrm{CWI}$

Transportes

Fransportes

Agropocuária

Mineraçáo

Metalurgia

Mecanica

Matorist Elótrico

Mararat de Transpone

Céluloso. Papei o Grat.

Ind. da Borracha

Quimica

P|ásticos

Ind. Toxtil

Vestuario a Caçachos indúztrias Diversas

industrias Diva
SUUP Com..

Consirugáa Cin.

comercio

TTansporto

Serviços

mpon $3 c_{0} 0$

Aemuneraçoss

Excedonlo Ento

V.A Custo da Falores Substos s/ Allvidads V.A. Preço Básico

Soma Linhas 1 a 22

Soma Linhas 23 a 44

Som Linhas 67 a 8

Soma Linhas $B 8$ a 110

Soma Linhas 1 a 112
L $118+L 124$ (Tot Geral
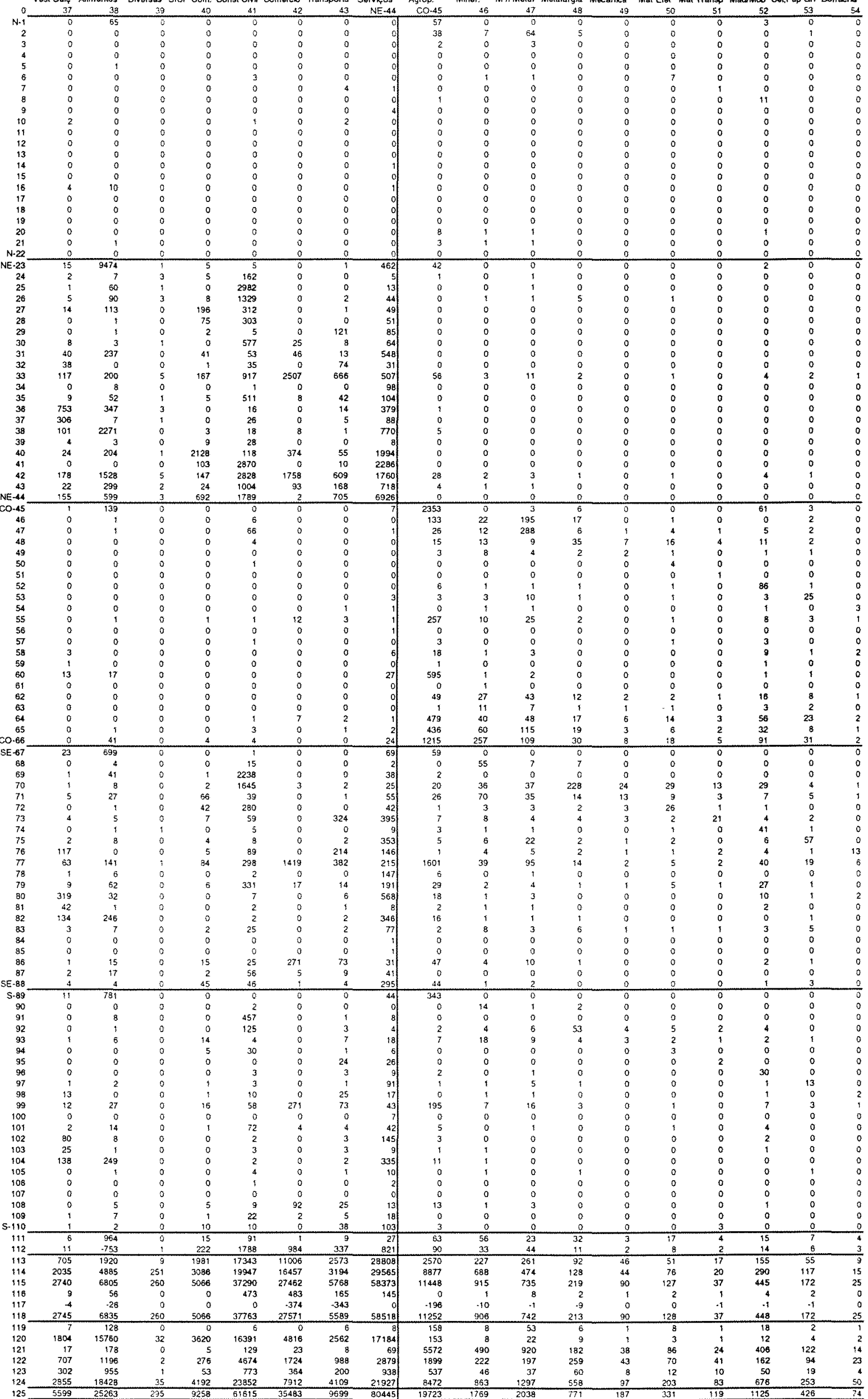
Matri 1985 - 5 Regios

Material Elattrico

Material te Transporne

Mactera a Mobiliátio

ind da Eorracha

Quimica

Plasticos

Ind Textil

ostutrío - Calçados Prod. Almontares

Slup Com.

Comstructo

Transpontes

Serviços

Agropecuaria

Minerats náo Motalicos

Motaurgia

Macanica

Matorial Elátrico

Madeina o Mobiliario

Colubese, Papel a Grál.

Ind da Borrach

Farmacoutic

Ind. TAxti

Vestuanio a Calçados

Prod. Alimentares

SIUP: Com..

Construcáa $\mathrm{Cl}$

Fr ansportes

Servicos

Agropecuária

Mineracáo Metalurgia

Material Esistrico

Material de Transporte

Madera a Mobiliário

Catusose, Papal a

Ind. ta Borracha
Quimica

Famacética

Plasticos

Vestuario a Calçacos

Ptod, Alimentares

SIUP Com..

Construçáa Civ

Comarcios

Tr ansport
Servecos

Agropecuária

Mirnorats náo Metalicos

Motaurgia

Matenal Elétrico

Material de Transpone

Madeira e Mobilltrio

ind da Borracha

Quimica

Tht

Vestuáno a Calçados

Prod. Alimentares

Siup o Com.

Conserucáa $\mathrm{CN}$

Combrcio

Transportes

inportacies

impostos

Remuneraçós

V.A. Custo do Fatoro

Impostos a/ Ativid ado V.A Procio Básico

Soma Linhas 1 a 22

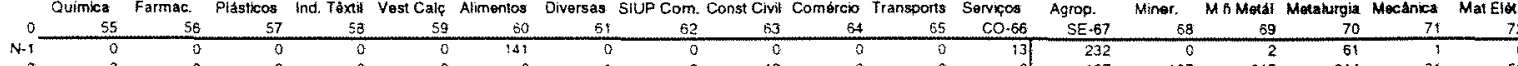
Soma Linhas 23 a Soma Linnas 67 a 8 Soma Unhas ag a 110 Soma Linnas 1 a 11 ?

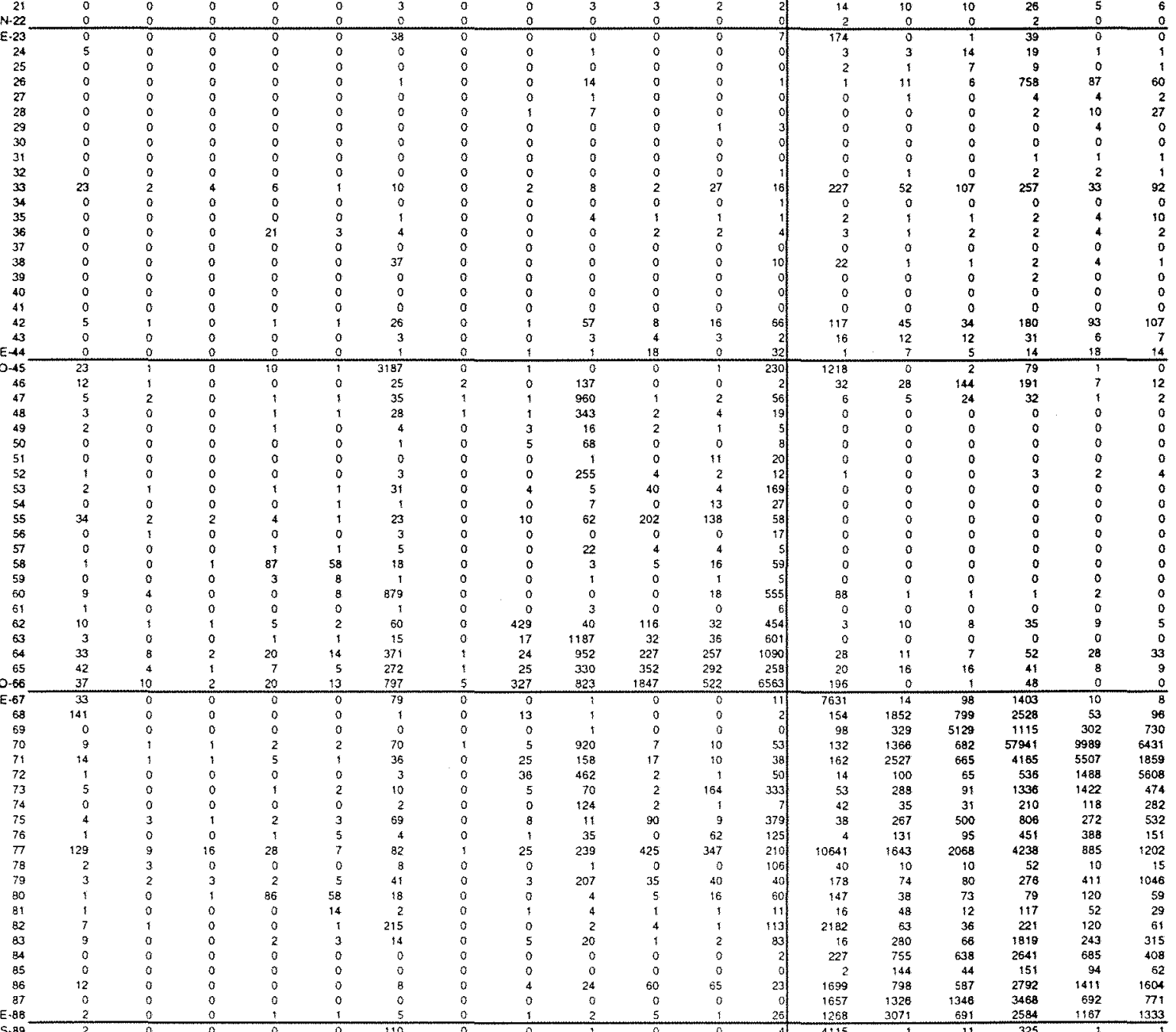

$-11 B+124$ (To $\mathrm{C}$

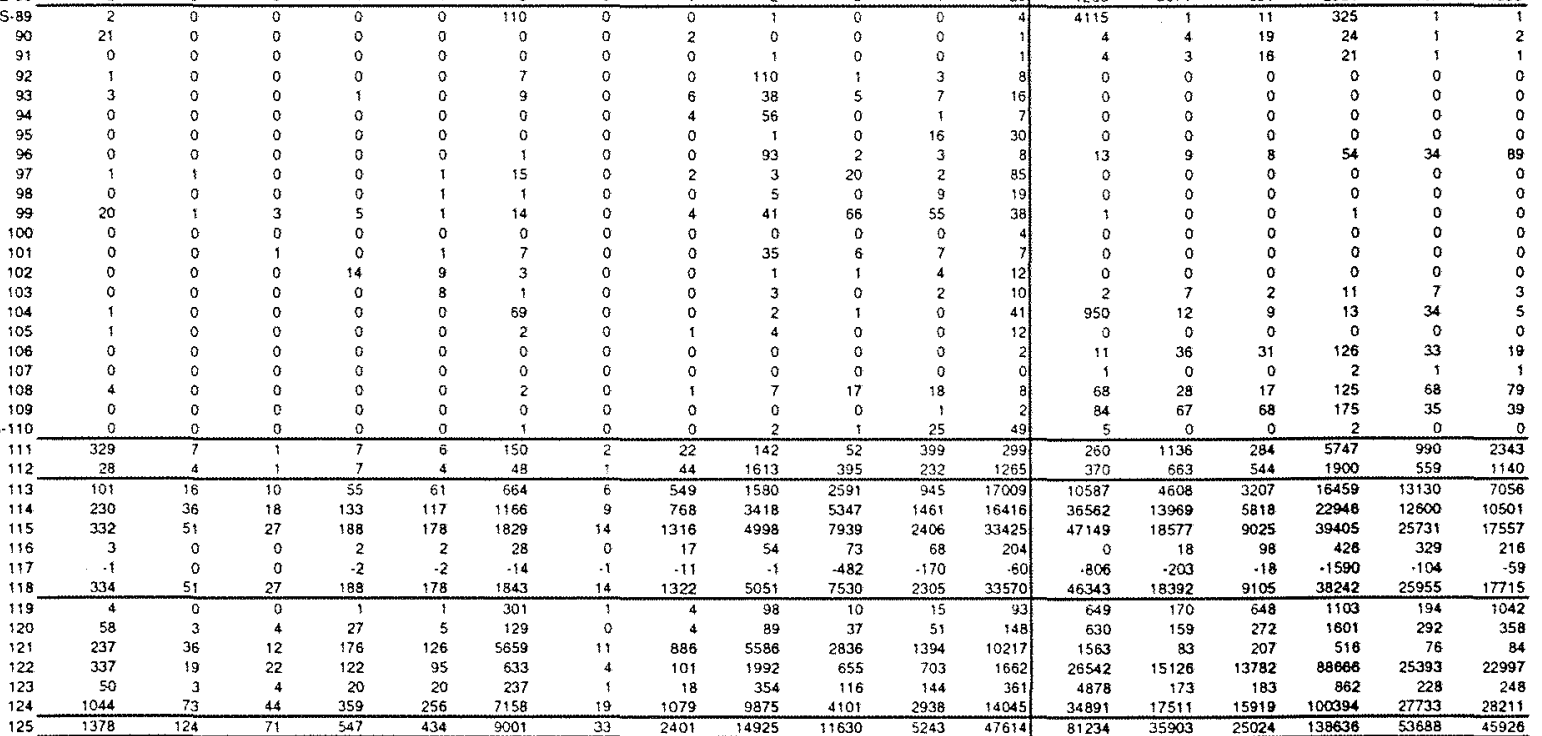


Mineraçàs năo Metálicos Motalurgia
Mecanica

Matarial Elatrico

Matorial de Transporto

Celutose, Papel Gra

ind da exracha

Quimica

P1́sticos

Ind. Thxti

Prod. Alimentares

SIUP - Com.

Construç âto $\mathrm{C}$

Comercio

Transporn

Agropocuánia

Minoraçäs năo Melálicos

Metalurgia
Mecánica

Matorial Elátrico

Material do Transporto

Madeira o Mobiliajo

Celulose, Papel o Grát

Ind. da Borracha

Famacoutica

Plásticos

Vestudino Calçados

Prod. Alimantares

SIUP - Comi..

Construça åo $\mathrm{C}$
Comercio

Transporte

Serviços

Agropecuá

Mineraçáo

Metalurgia

Macânica

Material de Transporto

Madeira - Mabilianio

Collusase. Papel o Gét.

Ind. da Borrach

Farmacbutica

P1asticos

Vestuátio o Calçados

Prod. Allmentares

SIUP C Con.-

construçáo CN

Combrcio
Transportes

Servicos

Agropecuárta

Mineraçăo

Minerais náa Metálleos Metalurgia

Macterial Élótrico-

Material de Transporto

Madeira a Mobiliario

Colutose, Papal o $\mathrm{C}$

Ind. da Bort
Ouimica

Farmacèutica

Ind. Tâx

Vestuário \& Calçados

Prod. Alimentares

Slup e Com.
Cons

Construcáa Clvif

Comércio

Traniportos

Agropecuana

Minerais náo Mátálico

Metaturgia

Macánica

Material de Transporte

Madeira a Mobiliario

Colutose. Papel o Grá.

Ind. da Borracha

Fauminaca

Plásticos

Ind. Textil

Prod Alimemasas

inctistrias Diversas

SIuP Com.

Constructo
Comercio

Transportes

Sorviços

Imponaçóa

A

Excedorto Eruto

V.A. Custo de Fatoras Subsidios s/ Ativivida V.A. Proco Basko

Soma Linhas 1 a 22 Soma Linhas 23 a d4

Some Linhas 89 a 110

Li18 L L 124 (Tol

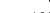

$2 \mathrm{~B}$

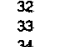

3

37
38
39
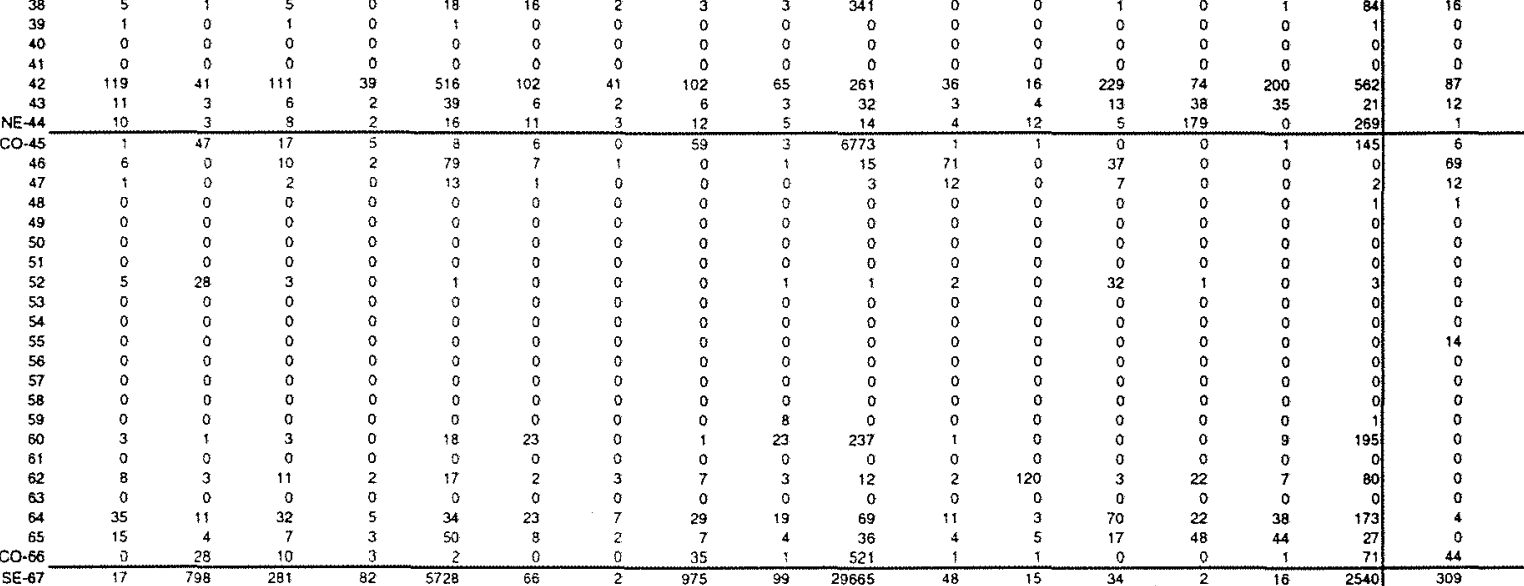

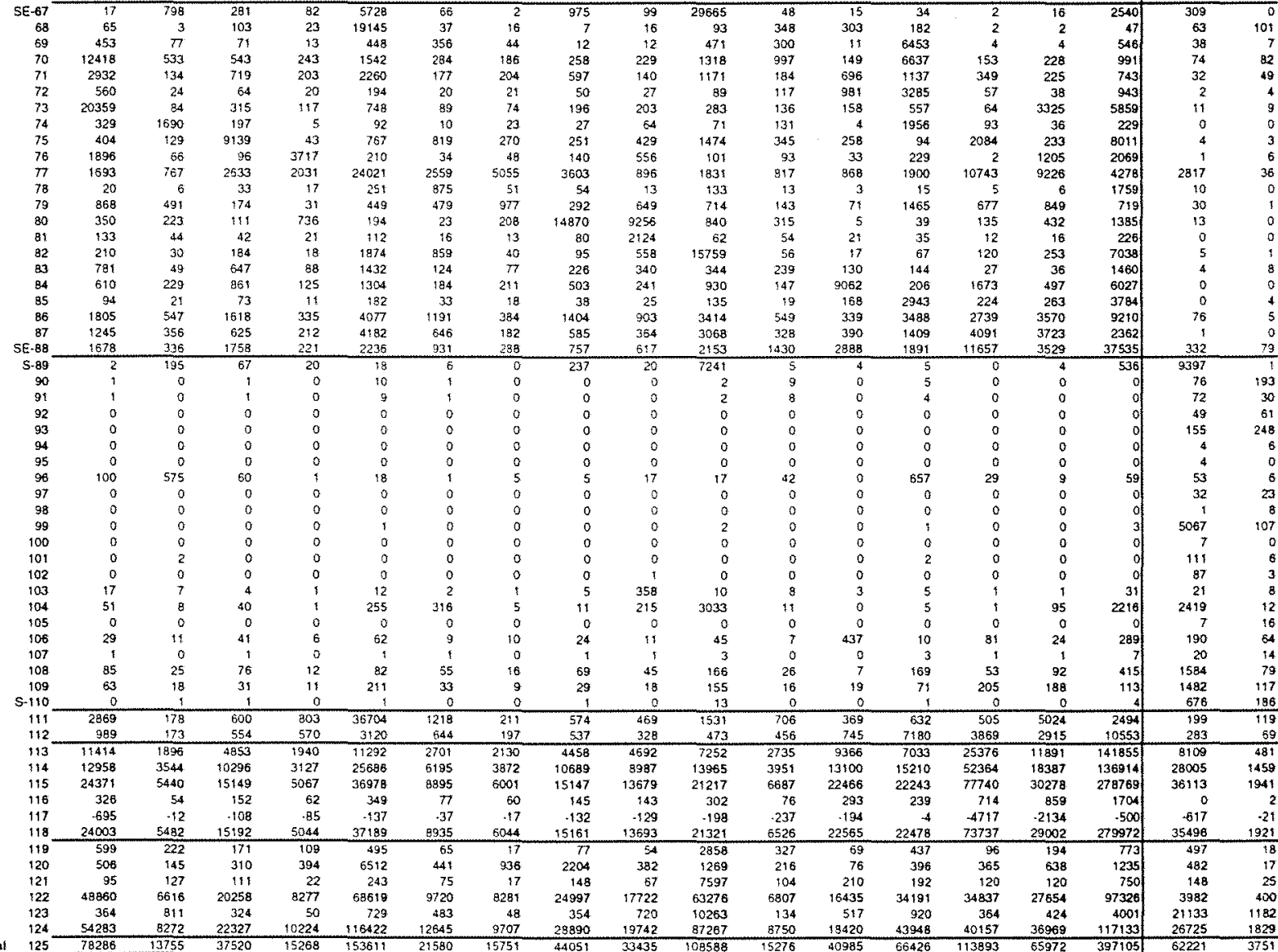


Material Elétrico

Materiai de I ransporte

Maderta a Mobilianio

Ind. da Borracha

Furmacou

Piásticos

Ind. Taxt

Vestuáric \& Calcados

Prod. Alimentares

Industrias Divers

Construça civ

Transporta

Servicos

Agropecuari

Mintraçáo

Metakurgia

Materinal Eláticico

Material de Transpone

Madoira o Mobilíánio

Ind. da Borracha

Ouimica

Plasticos

Ind. Taxall

industrias DNersas

Construciato Civil

Comércio

Transpor

Agropecuári

Mineraçás nāo Metálicos

Metalusgia

Materalal Elatirico

Material do Transport

Madeira e Mobilianco

Celuksa, Papel e

Quimica
Farmaciluica

Plasticos

ind. Taxtil

Prod. Allmemares

indusitrias Oversas

SIUP a Com..

Comstructo

Transportas

Agropecuat

Mineração

Mintrais nào Matálicos Motalurgia

Maternical Ejétrico

Material de Transporte

Colluloss. Papel a Grat

ind. da Borracha

Farmacoutica

Plásticos

Vestuário Calçacios

Prod. Alimentares

indestrias Diversas

Construçáa $\mathrm{C}$ ivi

Comércio

Servicioa

Agropecuária
Mineraçá

Minerais náo Metálicos Molalutgia

Material Elótrico

Matorial de Transponte Madeira Mobititrio

Celutose, Papel o Grá

Ind. da Borracha

Ouimica

Farmacéutica

Ind. Tíntion

Vestuário - Catçados

Prod. Alimentares

Industras ONat:

Constuucąo Cis

Comercio

Transportes

Importaçós

mpostio

Ramunoraçicos.

Excedenta Bruto

Imposios \&/ Alwitads

.

istersonse

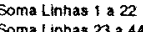

simesa

Soma Linhas 67 a 88

Soma Linhas 89 a 110

L $118+$ L 124 (Tot Ger
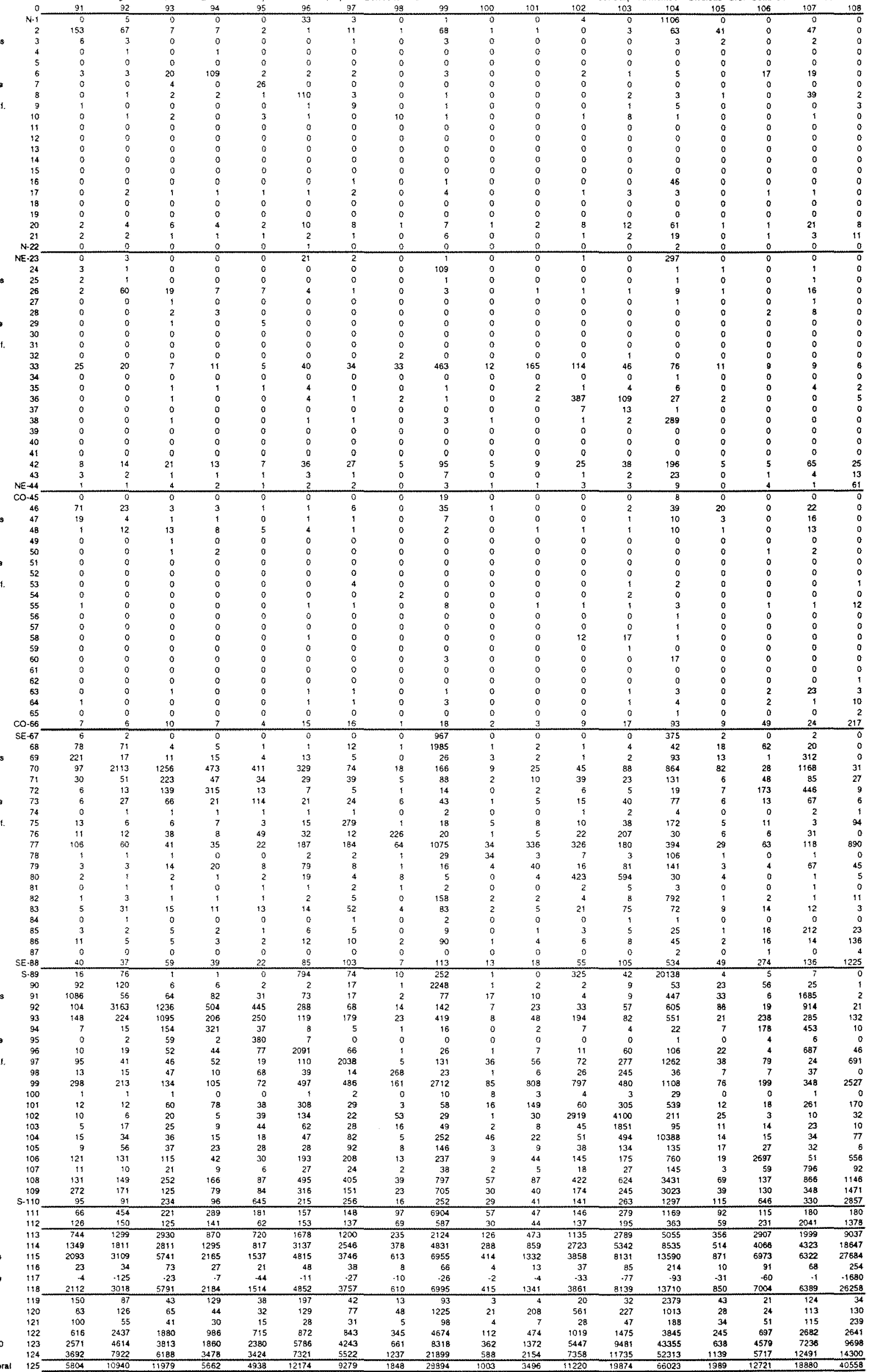
Material Eletrico

Material de Transporto

Madoira e Mobilíáno

ind. da Borracha

Ouimica

Plasticos

Vestuatrio a Caicados

Prod. Alimentat as

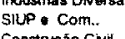

Construçáo Con

Transporios

Servicess

Agropecúánia

Sirrerais náo Matalicos Motalurgia

Material Elétrico

Matastial de Transporto

Madetra a Mobilation

Celutose. Papas a Graf

Ind da Borracha

Quimica

Plásticos Tuxtil

Vestuario Calçados

Prod. Alinentares

Silp Com.

Constructo to
Comercio

Transoortes

Servicos

Agropecuatio

Minerais náo Metálicos

Motasurgia

Mocánica
Matarial Elétrico

Materiat de Transporte

Mactira o Mobilario

Ind. da Eorracha

Farmacèutica

Plasticos

Vosuatio Galcados

Prod. Alimentas as

SIUP : Com..

Construcáo $\mathrm{CN}$

Transportas

Servicos

Agropecuaria

Mineraçáo

Metaturgia

Mecánica

Material Esétrico

Madeiza a Mobiliário

Colulose, Papol a

Quimica

Plásticos

vestuátio e Calcados

Prod. Almantlaras

Industrias Diversa

Constructo $C_{\text {CNI }}$

Comercio

Transpor

Agropocutatia
Minofaçáa

Minerais náa Motalicos Metalturgia

Mecánica

Matestal de Transport

Madoira o Mobillário

ind. da Borfacha

Quimica

Plasticos

Im. Taxtil

estuátio Calçado

indistrias Drersas

SIUP - Com..

Comório

Servicos

importaçós

Impostios

Remuneraćós

Excadionte Bruto

V.A. Custo de Fatores Subsidios s/ Alvidad V.A. Preço Básico

Soma Linhas 1 a 22

Soma Linhas 23 a 44

Soma Linhas 45 a

Suma Linhas 89 a 110

Soma Unhas 1 a 112
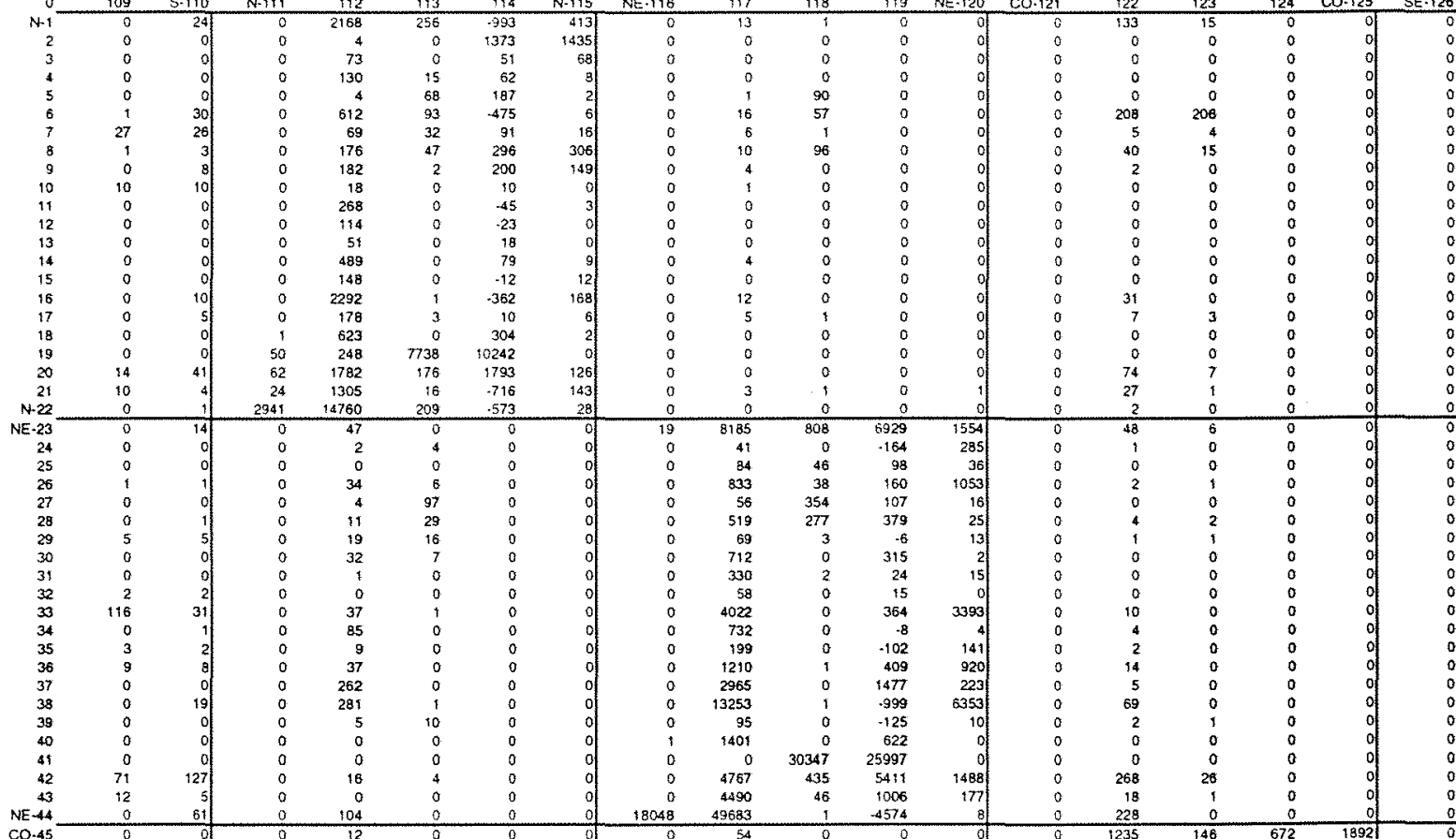

0.45
46

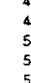

50
51
52

52
53
54

54
55
56
57

56
57
58
59
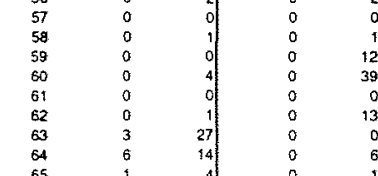

65
$C D .66$
$S E-67$

SE- 67
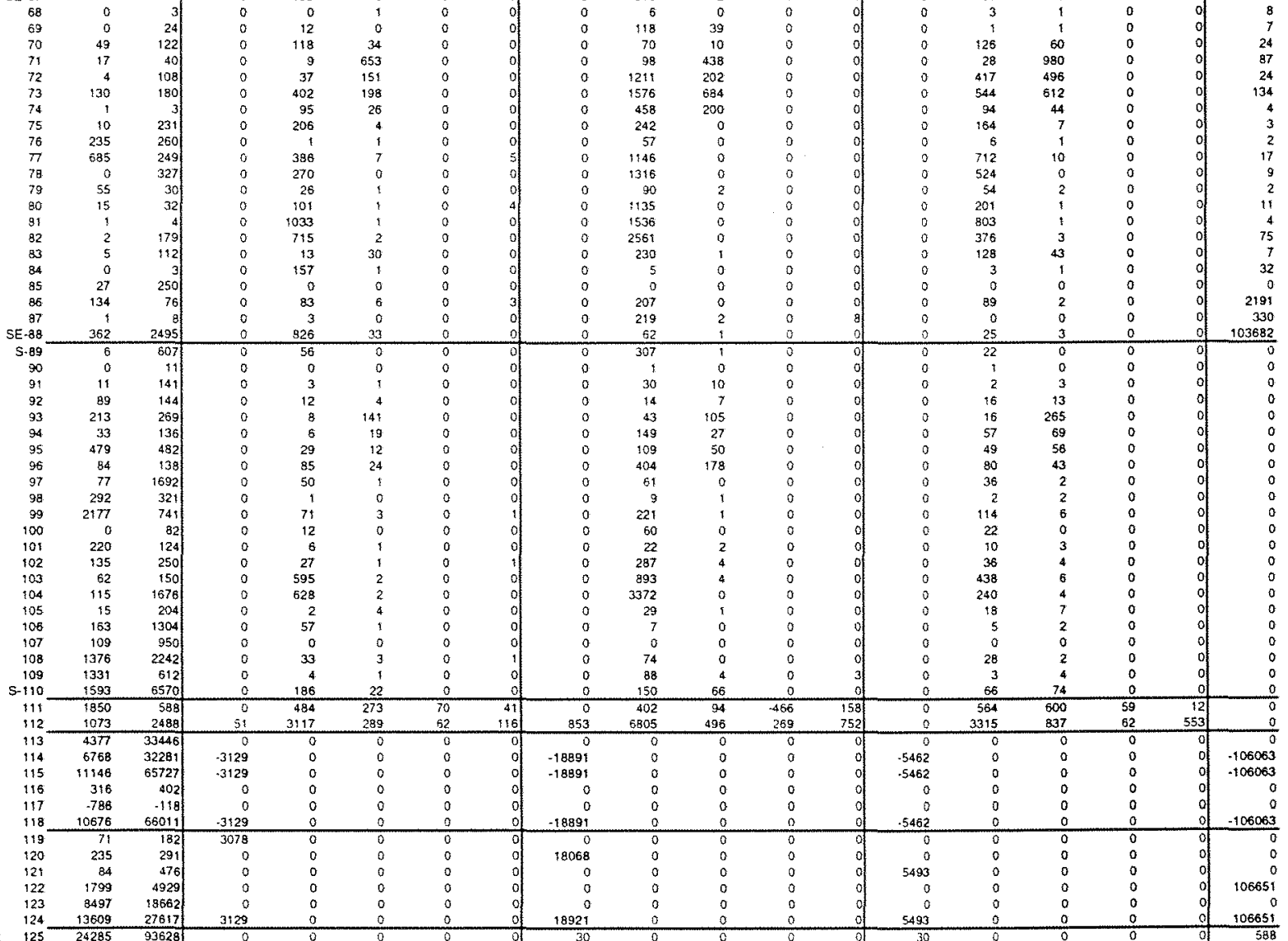


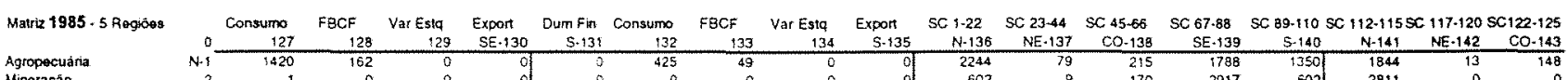

Motalurgia

Material Elótrico

Material de Transeone

Celulose, Papoi * Grat.

Ind. da Borracha
Ouimica

Farmacéutica

Ind. Toxiti

Vastuario a Calçacos

Prod. Allmentars

SHUP COM...

Comercio

Transportes

Agropecuária

Mineraça

Minnerais náo Matalicos

Metalurgia

Matorial Elétrico

Matsral de Transpon

Cesulosa, Papel Grát.

Ind da Borrache
Quimica

Famacoutica

Plástcos
Ind. Textll

Vestuárto e Calcados

Prod. Allmertares
Irduistrias Diversas

SUUP o Com.r.

combrcio

Transportes

Agropecuária

Agropecuàr

Mefahrgia

Matarial Esitrioo

Material de Transporte

Madoka
Colulose, Papol o Grat

Ind. da Berracha

Fulmica

Ptásticos

Vestuátio Calçados

Prod. Alsmertares

SIUP - Com.

Consiructo

Tranapor

Servicos

Agropecuánia

Minerais náo Metálicos Metalurgia

Mecánica
Material Ejético

Material de Tfansconte

Celulose, Papel e Grál.

ind. da Bortacha

Ouimica

Farmacéutica

ind. Textil

Vestuario Calçacos

Prod. Alimentaros

SIUP o Com.

Construçáo

Transportes

Aervicos

Mineraçáo Matajurgia

Mecánica
Material Elétrico

Material de Transporte

Celulose. Papel a Grát

ind da Borracha.

Quinnica

Plásticos

Vestuatrio Cakçados

Prod. Alimentar

SIUP COM.

Construxta $\mathrm{C}$
Comercto

Transportes

Importacios

Impostacios

Remunesacóes

Excedento Bruo
V.A. Custo de Fatores

Impostos \&/Atvidado

V.A. Preco Básico

Soma Linhas i a 22

Soma Linhas 45 a 66

Soma Linhas 67 a 88

Soma Linnas I a 112

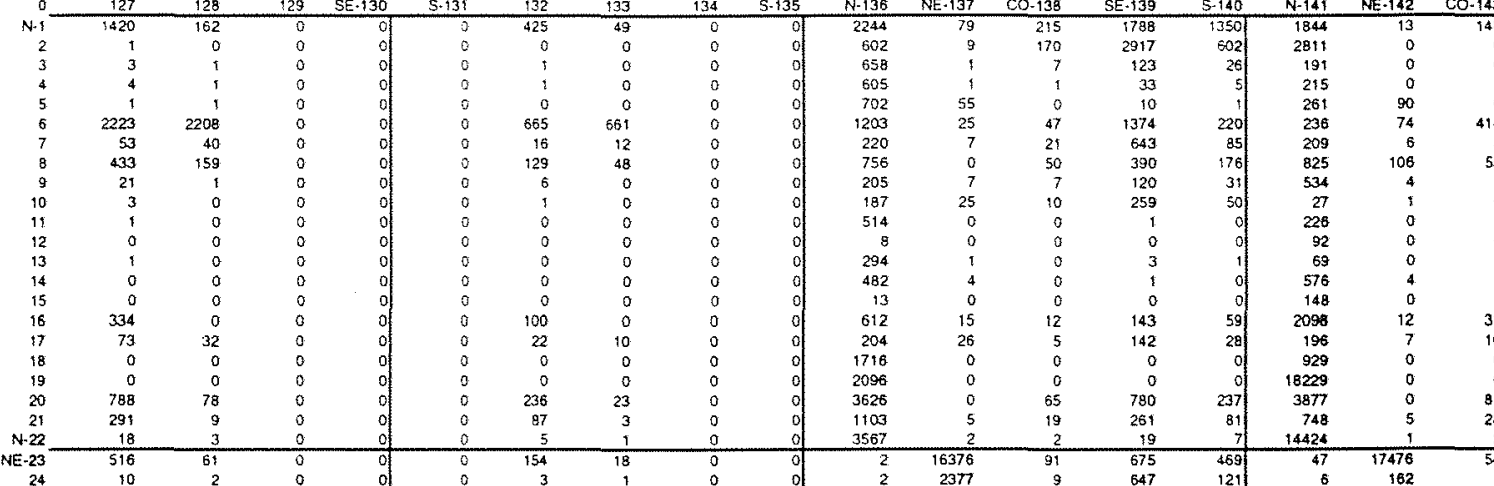

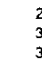

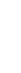
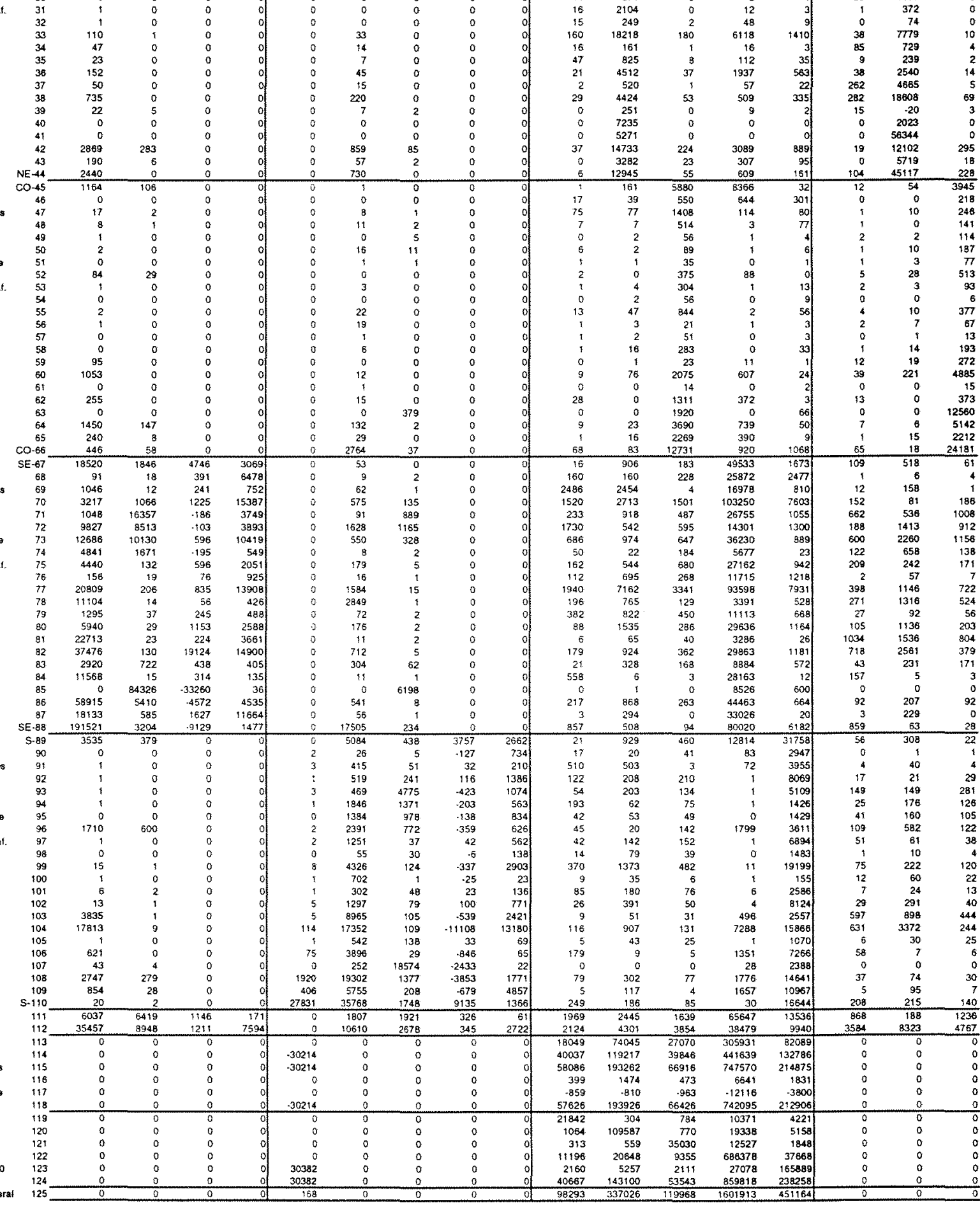
Matrix 1985 - 5 Regioes

Agropecuaria

Mineraça

Minerais náo Metálicos

Metahurgia

Material Elstrico

Materlal de Ttansporte

Madera Mosida

Callibs. Papalo

ind. da Borracha

Quinica

Plísticos

ind. Textll

Vestuário a Caccados

Prod. Alimentases.

Industrias DNars

Construçáo Civat

Combrcio

Transportes

Servicos

Agropecuara

Mineraçắo

Moctno

Material Elétrico

Material de Transpone

Celulose, Papel Grát

ind da Borracha

Ourmica

Farmacturtic

ind Toxtil

Vastuatio Caicacos

Prod. Alimertares

industrlas Dwers

Construçáo Cin

comercio

Iransportes

Agropecuatia

Wheracto

Minerais năo Motábico

Metakurgia

Mecánica
Matarial Eletrico

Matsrial de Yransponto

Madaira a Mobitário

Colulose, Papel Gral

Quimica

Farmacevica

ind. Taxti

Vestuáric - Cakfados

Prod. Allmentares

SIUP Com.

Construxąo Civa

Comercio

Iransportes

Serviços

Agropecuári
Mineraçáo

Mineraça

Mintaiturgia

Mecanica

Malerial Éatrico

Materfial de Transponte

Madisa a Modikano

Colulose, Papoi Grál

Ind. da Borracha

Farmacéutic

Piásticos

ind Taxil

Vestuario Cakçacosos

industrlas DNatso

Consiruç一兀 $\mathrm{CN}$

comercio

Ttansporte

Serviços

Agropecuán

Minerats náo Motalicas

Metalurgia

Mecanica

Material Eletrico

Material de Transtone

Madelra o Mobitiáno

Gellusose, Papel Grat

Ind. da Borracha

Qulmica

Farmactula

Plasicos

Vestuario * Caçados

Prod. Alimentares

industrias Diversos

SIUP Com..

Construçato

Comercio

Servicos

imponaço

imposios

Remuneracos

V.A. Custo do Fatores

Impostos 8 / Alvidado

Subsidjos \& Alnda

V.A. Preço Bassico

Some Linnas 1 a 22

Soma Linas 23 a 4

Soma Linhas 67 a 80

Soma Linhas 67 a 88

Soma Lininas i a 112

$L 118+L 124$ (Tot Gera

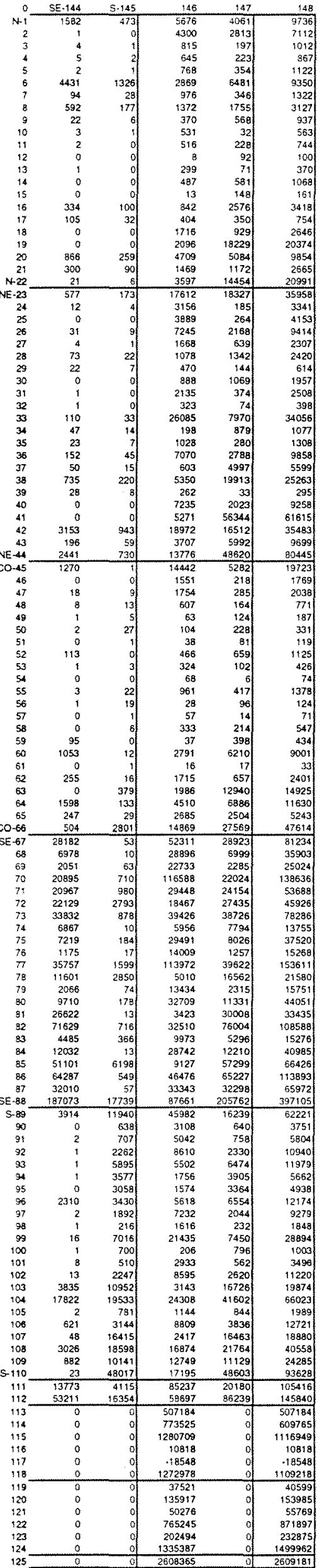


ANEXO B

Tabela B.1: Versão completa da matriz de insumo-produto inter-regional para o Brasil, 1990. Em milhões de cruzeiros de 1990.

Fonte: dados da pesquisa. 


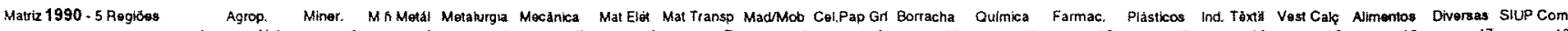
Agropecuária
Mineraçăo Minerais nảo Méálicos Matalurgl Material Eletrico Material de Transpon Madelta a Mobilianto Celiviose, Papelo Ouimica Plasticos Prod. Almentar as indistrias DNara
SIUP Com.. Construcayo CNA Transport Transport Agropecuária: Minorais năo Maralleos Meqalurģia Material de Transporto Madeira - Mobilitio ind. da Eorractia

Farmacâtutica Plásticos

Vestuário Cakcados Prod. Alimentares SIUP e Com.. Construçáo Transpones Servicos Agropecuária Mineraçáo Mecãnka Material Ejétrico Material de Transpon Colubosa, Papat a Grát. Ind. da Borrachs Farmacỏutica Plísticos

Vostuatio o Calcados Prod. Alimentares SIUP * Com... Construc a co $\mathrm{Ci}$ Comberio Servicos Agropecuária Mineraçáa Metalurgia

Matănica

Material de Transporta Madeitra a Mobiliátio Celulose. Papel o Grát. not. da Borracha Earmacò

Parmaciutca

Ind Taxti

Vestuário Calçacdos Prod. Alimentares Indusitias DNeras.
SiuPe Com. Construção Ca Comertcio Transpontes Servicos Agropecuaria Mineraçáo Metalurgi Macănica Materiat Eletrico Madera e Mobiliário Celuliosa. Papel Gral. Ind. da Borrach
Quimica Farmacautica Plàsticos

Vestuario a Calçacos Prod. Alimerasias indústrias Divorsa Construção Cha Transportes Servicas importaçódes Remunaraçios Excedente Bruto A Custo de Fatores Subsidios s A Alvidad V.A Proģo Basico Somal Linhas 1 a 22 Soma Linhas 23 a 44 Soma Linhas 45 a 66 Soma Lunis 89 a 1 Soma Linhas 1 a 112
$L 118+L 124$ (Tot Gor
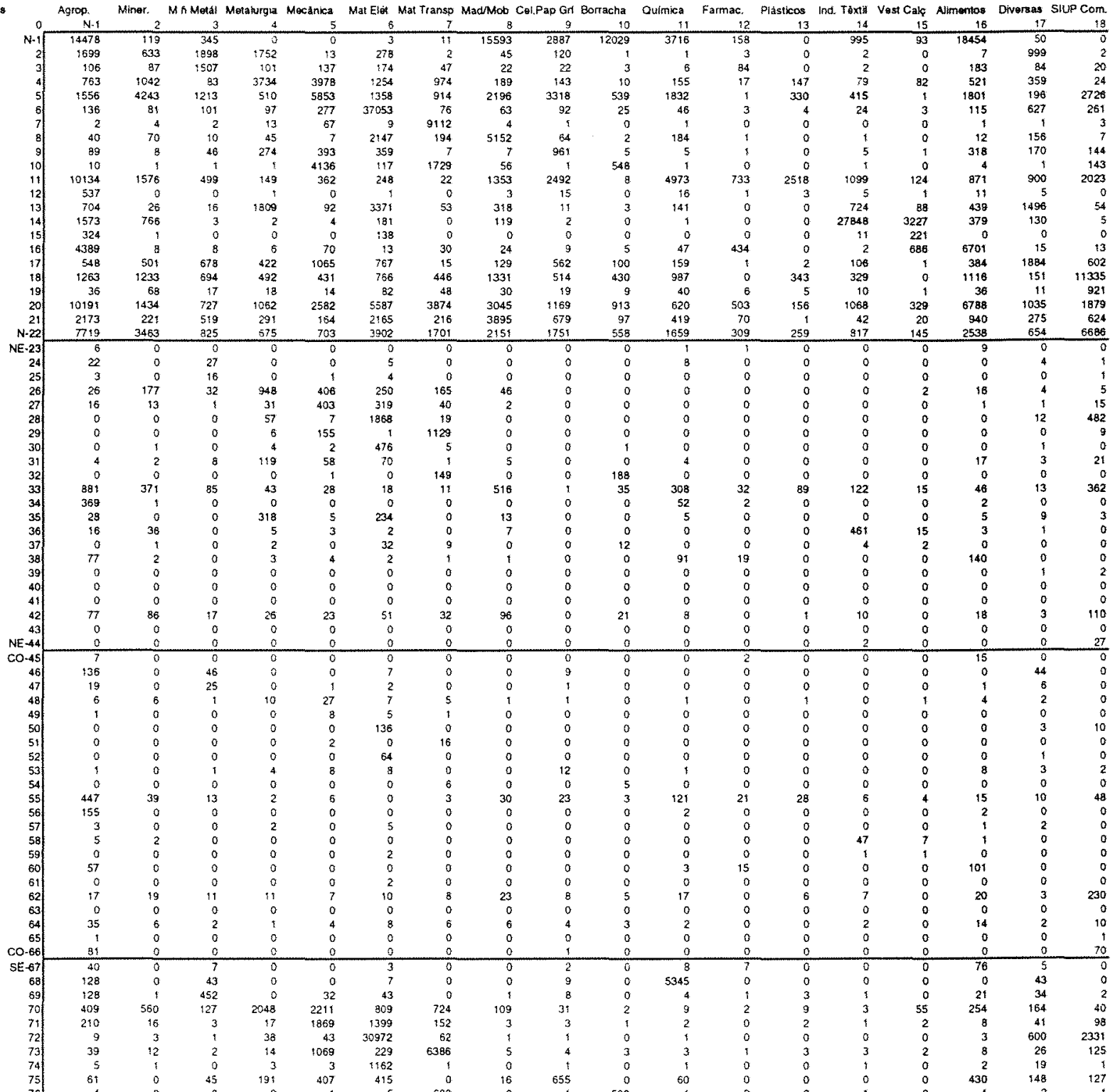
Minotąąa náo Mớálicos Mecalurgica

Material Elatrico Matenai de Transporta

Colubse. Papel o Grál.

Quimica

Famacoura

ind Taxt

Vestudio Cakcacos Prod. Alumentares

SIUP Com..

Comercio

Transportes
Servcos

Agropecuan

Minarais náo Metáticos Metahurgia
Mecanica

Matorial Eletrico

Material de Transporto

Colubse, $\mathrm{P}$ apel Grát.

ind. da Borrach

Farmacéut

Písticos

Vestuatio Calçados

incustrias DNersas

Stup Com..

comercio

Transportes
Serviços

Agropocuária

Mineracáo

Metahurgia

Mocatrica
Material Eletulico

Matoriai de Transporte

Colutase Papel Grat

Ind. da Borracha

Oulmica

Plásticos

Ind. Toxti

Prod. Akinentares

Industnas DNers

Construxás CN

Comercio

Serviços

Agropectúi

Minerais nảo Metálico

Motalurgia

Mecánca
Material Elítrico

Material dransporte

Geluibse Papel Grá

Ind. da Borrach

Famacoutic

ind. Toxt

Vestuano o Calçados Prod. Alimentaras

SUUP Com.

Construçà $\mathrm{Civ}$

Transportes

Serviços

Agropecua na

Mineracăo

Metaurgia

Mocáncas
Material Elotrico

Material transconto

Madeira a Mobiliarto

ind. da Borracha

Fuimica

Plasticos

Ind. Toxt

Pestuano \& Calcados

Industrias DNafsa

SIUP \& Com.

Camarcio

Transporte

Servicos

Importacios

Remunatacóns

A. Custo do Fato

impostos s/ Alvidade

Subsidios s/ Atividad

Soma Linhas 1 a

Soma Linhas 23 a 44

Soma Linhas 45 a 66
Soma Linhas 67 a 88

Soma Lnnas 89 a 110

Soma Linhas 1 112

\begin{tabular}{|c|c|c|c|c|c|c|c|c|c|c|c|c|c|c|c|c|c|c|}
\hline 0 & 19 & 20 & 21 & $N \leqslant 22$ & $\mathrm{NE}-23$ & 24 & 25 & 26 & 27 & 28 & 29 & 30 & $3 !$ & 32 & 33 & 34 & 35 & 36 \\
\hline$N-1$ & 14 & 0 & 0 & 919 & 5 & 0 & 0 & 0 & 0 & 0 & 0 & 434 & 7 & o & 6 & 0 & 0 & $\overline{0}$ \\
\hline 2 & 4716 & a & 0 & 25 & 2 & 5 & 0 & 109 & 0 & 12 & 0 & 0 & 0 & 0 & 31 & 0 & 0 & 0 \\
\hline 3 & 18362 & 38 & 1 & \$1 & 0 & 0 & 0 & 24 & 1 & 1 & 0 & 0 & 0 & 0 & 1 & 0 & 0 & 0 \\
\hline 4. & 13223 & 55 & 9 & 234 & 0 & 0 & 0 & 21 & $t$ & 0 & $i$ & 0 & 0 & 0 & 3 & 0 & 0 & 0 \\
\hline 5 & 430 & 95 & 9 & 4045 & 46 & 12 & 13 & 116 & 1323 & 412 & 33 & 0 & 0 & 0 & 11 & 0 & 0 & 5 \\
\hline 6 & 1873 & 42 & 11 & 296 & z & 0 & : & 85 & 97 & 423 & 7 & 0 & 0 & 0 & 0 & 0 & 0 & 0 \\
\hline 7 & 37 & 0 & 819 & 104 & 0 & 0 & 0 & 0 & 1 & 0 & 49 & 0 & $a$ & 0 & 0 & 0 & 0 & 0 \\
\hline 8 & 7696 & 182 & 19 & 39 & 0 & 0 & 0 & 5 & 0 & 0 & 0 & 0 & 0 & 0 & 0 & 0 & 0 & 0 \\
\hline 9 & 24 & 559 & 45 & 1276 & 0 & 0 & 0 & 19 & 11 & 22 & 0 & 0 & 13 & 0 & $i$ & 0 & 0 & 0 \\
\hline 10 & 854 & 2 & 746 & 2049 & 0 & 0 & 0 & 0 & 229 & 0 & 17 & 17 & 0 & 570 & 0 & 0 & 0 & $f$ \\
\hline 11 & 2768 & 17010 & 4876 & 2894 & 0 & 0 & 0 & 6 & 0 & 0 & 0 & 0 & 0 & 0 & 0 & 0 & 0 & 0 \\
\hline 12 & & 0 & 0 & 225 & 0 & 0 & 0 & 0 & 0 & 0 & 0 & 0 & 0 & 0 & 0 & 0 & 0 & 0 \\
\hline 13 & 4693 & 580 & 86 & 240 & 0 & 0 & 0 & 16 & \{ & 0 & 0 & 0 & 0 & 2 & 0 & 0 & 0 & 1 \\
\hline 14 & 2 & 200 & 257 & $3651 \mid$ & 0 & 0 & 0 & 5 & 0 & 0 & 0 & 0 & 0 & 69 & 0 & 0 & 0 & 41 \\
\hline 15 & 0 & 0 & 0 & 68 & 0 & 0 & 0 & 0 & 0 & 0 & 0 & 0 & 0 & 0 & 0 & 0 & 0 & 0 \\
\hline 16 & 21 & 21 & 15 & 1933 & 3 & $a$ & 0 & 5 & 4 & 0 & 0 & 0 & 0 & 4 & 0 & 0 & 0 & 0 \\
\hline 17 & 736 & 38 & 6 & 1247 & $\$ 1 x$ & 0 & 7 & 833 & 38 & 7 & 2 & 0 & 3 & 0 & 0 & 0 & 0 & 0 \\
\hline 18 & 446 & 14425 & 850 & 25367 & 0 & $a$ & 0 & 0 & 0 & 0 & 0 & 0 & 0 & 0 & 0 & 0 & 0 & 0 \\
\hline 19 & 27883 & 360 & 157 & 12442 & 0 & 0 & 0 & 0 & 0 & 0 & 0 & 0 & 0 & 0 & 0 & 0 & 0 & 0 \\
\hline 20 & 9158 & 2782 & 1928 & 4798 & 0 & 0 & 0 & $t$ & 0 & 0 & 0 & 0 & 0 & 0 & 0 & 0 & 0 & 0 \\
\hline 21 & 3330 & 9168 & 283 & 2974 & 45 & 0 & 20 & 2 & $\$$ & 6 & 0 & 16 & 0 & 0 & 0 & 0 & 0 & \\
\hline+22 & 3250 & 12528 & 3477 & 28382 & 0 & 0 & 0 & 14 & 1 & 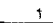 & 0 & 4 & 1 & 1 & 0 & 0 & 0 & \\
\hline$E \cdot 23$ & 0 & 0 & 0 & 50 & 73186 & 195 & 1891 & 1130 & 17 & T & 0 & 1518 & 308 & $\overline{B 25}$ & 27535 & 235 & 7 & 32461 \\
\hline 24 & 95 & 0 & 0 & 29 & 1210 & 3171 & 3928 & 7276 & 193 & $\$ 10$ & 0 & 0 & 165 & 51 & 102583 & 14 & 18 & \\
\hline 25 & 1097 & 0 & 0 & 0 & 168 & 292 & 12969 & 2042 & 26 & 533 & 105 & 114 & 2 & 5 & 370 & 195 & 14 & 8 \\
\hline 26 & 3344 & 2 & 7 & 17) & 376 & 1412 & 1318 & 62600 & 2813 & 9560 & 1009 & 857 & 279 & $4 \theta$ & 4272 & 21 & 26 & 123 \\
\hline 27 & 298 & 4 & $z$ & 30 & 1179 & 7222 & 1508 & 1232 & 5300 & 772 & 144 & 350 & 119 & 104 & 3056 & 34 & 166 & 1142 \\
\hline 28 & 2999 & 0 & $\mathfrak{f}$ & 5 & 20 & 207 & 27 & 214 & $545 i$ & 6567 & 230 & 8 & 4 & 2 & 150 & 0 & 3 & 22 \\
\hline 29 & 4 & 0 & 364 & 373 & 7 & 23 & 5 & 4 & 34 & 12 & 235 & 7 & 0 & 0 & 10 & 0 & 0 & 3 \\
\hline 30 & 19 & 0 & 1 & 2 & 593 & 5 & 34 & 197 & 58 & 245 & 130 & 2865 & 0 & 7 & 664 & $i$ & 3 & 2 \\
\hline 31 & 51 & 22 & 3 & 77 & 431 & 44 & 2363 & 333 & 93 & 660 & 22 & 68 & 15366 & 3 & 2363 & 342 & 590 & 607 \\
\hline 32 & 6 & 0 & 147 & 41) & 3 & 5 & 1 & 89 & 383 & 4 & 120 & 26 & 0 & 1013 & 7 & 0 & 1 & \\
\hline 33 & 518 & 293 & 377 & 148 & 28220 & 1740 & 3886 & 3575 & 304 & 916 & 121 & 1151 & 1729 & 1294 & 182520 & 1799 & 9155 & 6902 \\
\hline 34 & 2 & 0 & 0 & 103 & 464 & 5 & 3 & 4 & 2 & $\mathfrak{f}$ & 0 & 2 & 2 & 1 & 36 & 240 & ? & 13 \\
\hline 35 & $9 a 2$ & 17 & 4 & 5) & 381 & 8 & 48 & 60 & 6 & 127 & 12 & 589 & 9 & 0 & $5 B 4$ & so & 217 & 210 \\
\hline 36 & 20 & 0 & 2 & 98 & 1904 & 20 & 43 & 43 & 16 & 9 & 2 & 605 & 40 & 329 & 211 & 8 & 7 & 42742 \\
\hline 37 & 3 & 0 & 4 & 3) & 603 & 18 & ? & 17 & 25 & i & 8 & 17 & 2 & 71 & 70 & 7 & 1 & 379 \\
\hline 38 & 16 & 0 & 0 & 345 & 159006 & 306 & 16 & 163 & 36 & 11 & 3 & 8 & 73 & 2 & 4342 & 2032 & 7 & 170 \\
\hline 39 & 1 & 0 & 0 & 6 & 19 & $23 \$ 7$ & 5 & 809 & 83 & 0 & 0 & 0 & 67 & 2 & 2896 & 0 & 4 & 1 \\
\hline 40 & 0 & 0 & 0 & of & 4378 & 2350 & 7194 & 17765 & 924 & 1540 & 169 & 1335 & 1214 & 283 & 31024 & 192 & 850 & 4474 \\
\hline 41 & 0 & 0 & 0 & of & 5 & 0 & 0 & 0 & 0 & 0 & 0 & 0 & 0 & 0 & & 0 & 0 & \\
\hline 42 & 179 & 34 & 75 & $\pi$ & 18885 & 3976 & 3649 & 7716 & 3237 & 2265 & 58.3 & 4076 & 2734 & 752 & 22082 & 1595 & 1008 & 6533 \\
\hline 43 & 0 & 0 & 0 & of & 7529 & 323 & 2839 & 1315 & 256 & 527 & 98 & 1856 & 450 & 356 & 3624 & 207 & 77 & 2182 \\
\hline 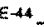 & 2 & 10 & 81 & 25 & 10336 & 3805 & 3757 & 2223 & 1574 & 1138 & 400 & 1457 & 2251 & 197 & 9698 & 1013 & 1082 & 2840 \\
\hline 0 & 0 & 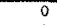 & 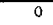 & 101 & 50 & 0 & 0 & 17 & 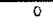 & $\overline{0}$ & 1 & 216 & 23 & & 30 & & & \\
\hline
\end{tabular}

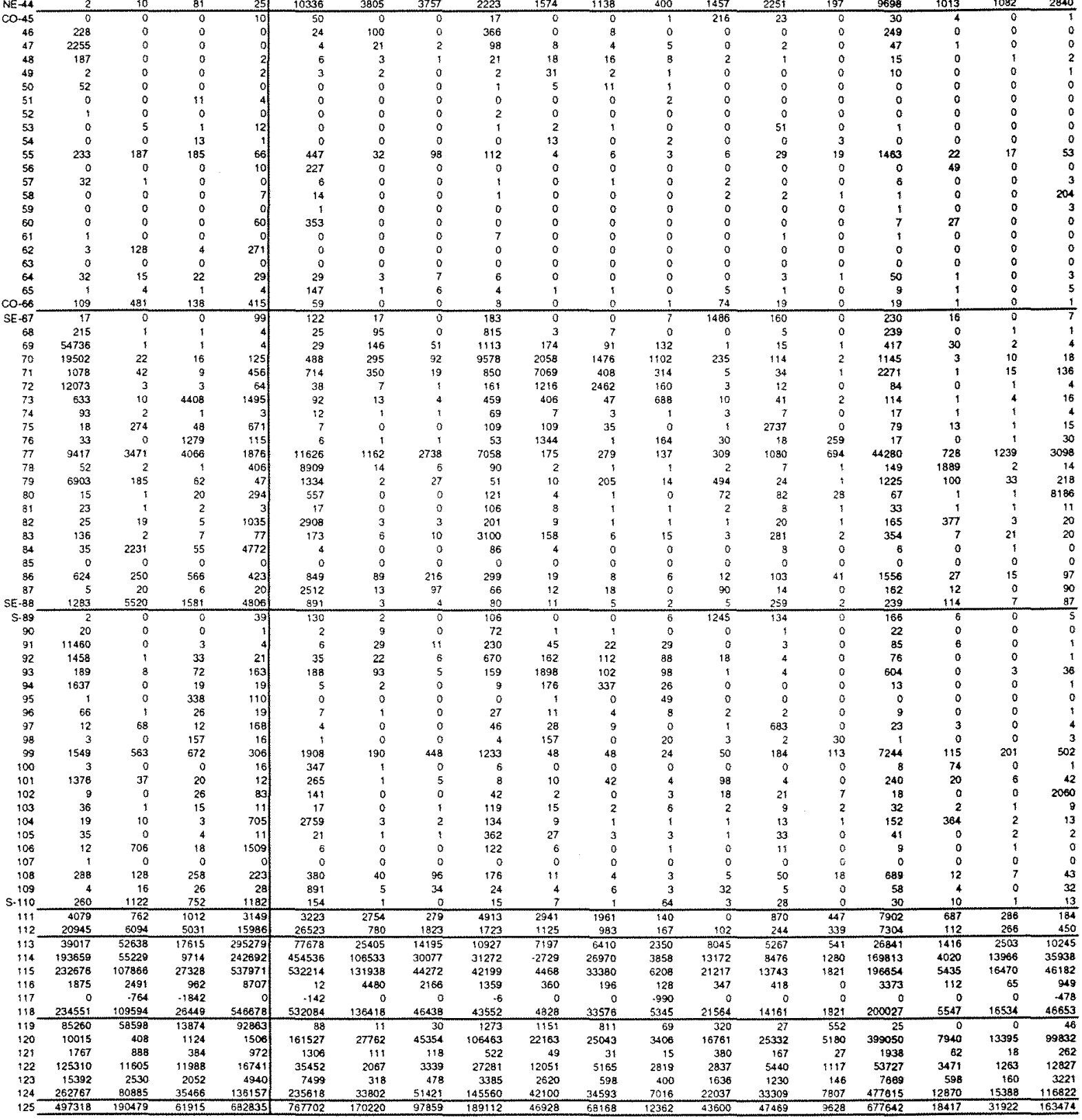


Agropecuária

Agropecuana

Minerals náo Metálicos

Metalurgia

Macánica

Matalial de Transporte Celubose, Papel e Grat Ind. da Borracha

Fasmacelutic

Plásticos

Yastuatio a Calcados Prod. Alimentares

Industrias DVirsa
SlUP O Com..

Construça $\mathrm{C}$

Transportes

Serviços

Minerais nảo Metálicos

Metalurgia
Mecanica

Naterial Elésrico

Material de Transporte

Celuriose Papel Grat.

Ind. da Borracha

Quimica

Plásticos

ind. Toxxll
Vestuario calçados

Prod. Allmentares

Indüstrias Diversas

Construcăo Civit

Combrcio

Transportes

Agropecos

Mineraçăo

Minerats náo Metdicos Motalurga

Macalerial Elétrico

Material de Transporie Madoira a Mobsisiario

Celulase, Papel $\theta$ Grat.

Ind. da Borracha

Quimica

plásticos.

ind. Textil

Vestuário Calcados

Induistrias Dhersas

Sonstruçáco C

Comercio

Transportes

Agropecuári

Mintaraça à

Menalungia

Mocanica

Matorial Elétrico

Material de Transporte

Culuras Pabola

ind. da Borracha

Qulmica

Plástico

ind. Taxt

Vestuano Caicados

SIUP - Com.

Construcaso CN

Transportes

Senvicos

Importaçcos

impostos

Aemunaraçoss

Excodento Bruto

impostos a A Atividade Substidios s/Atividacio V.A. Preço Básicos

Soma Linhas 1 a 22

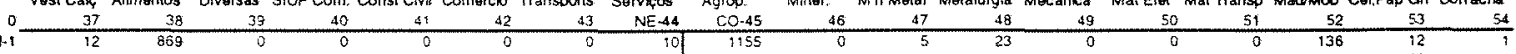
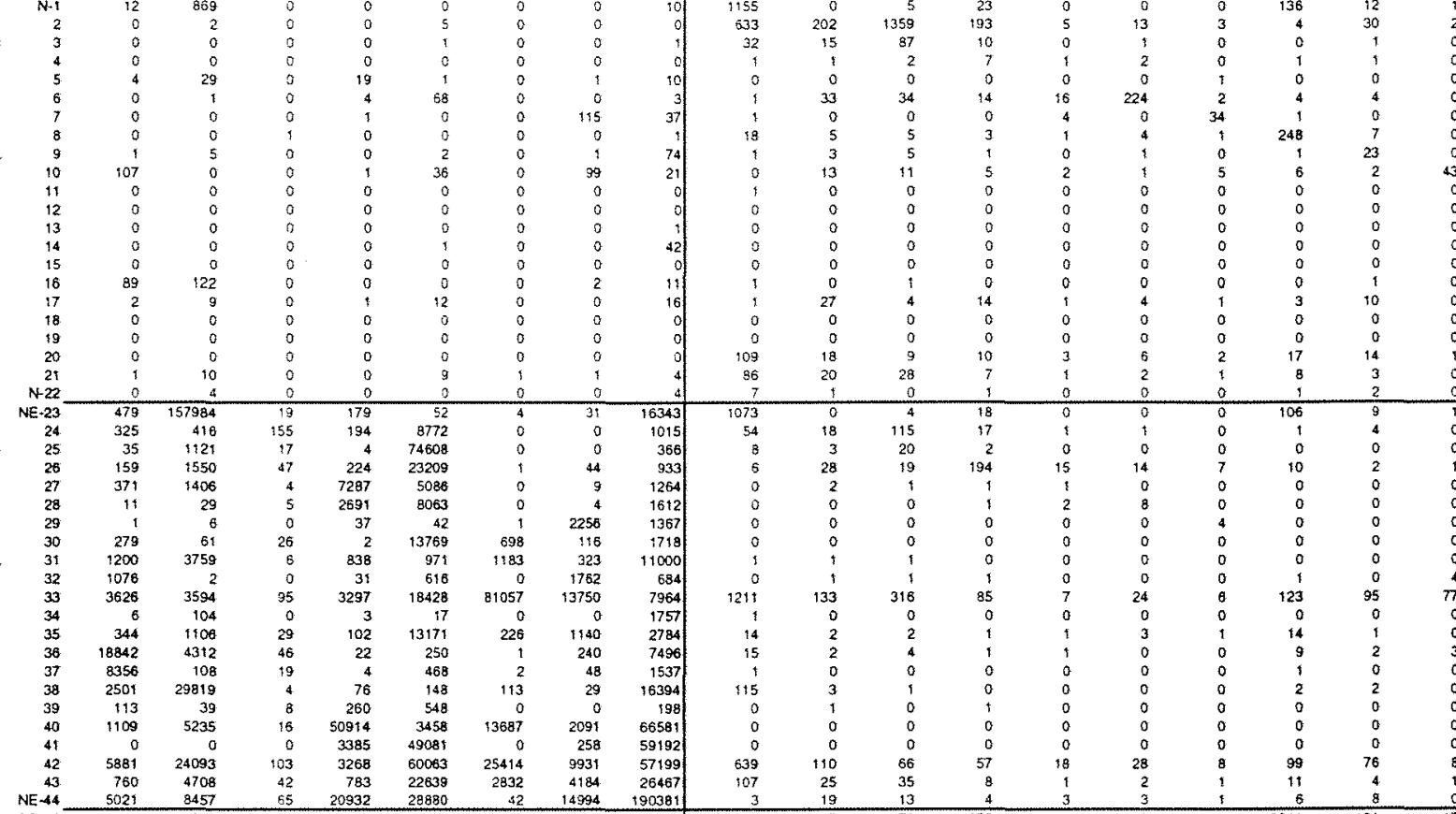

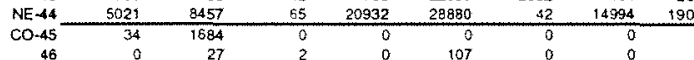

\section{Soma Linhas 45 a 66} Soma Linhas 89 a 110 Soma Unhas 1 a 112
$L 118+L$ L 124 (Tot Gorat

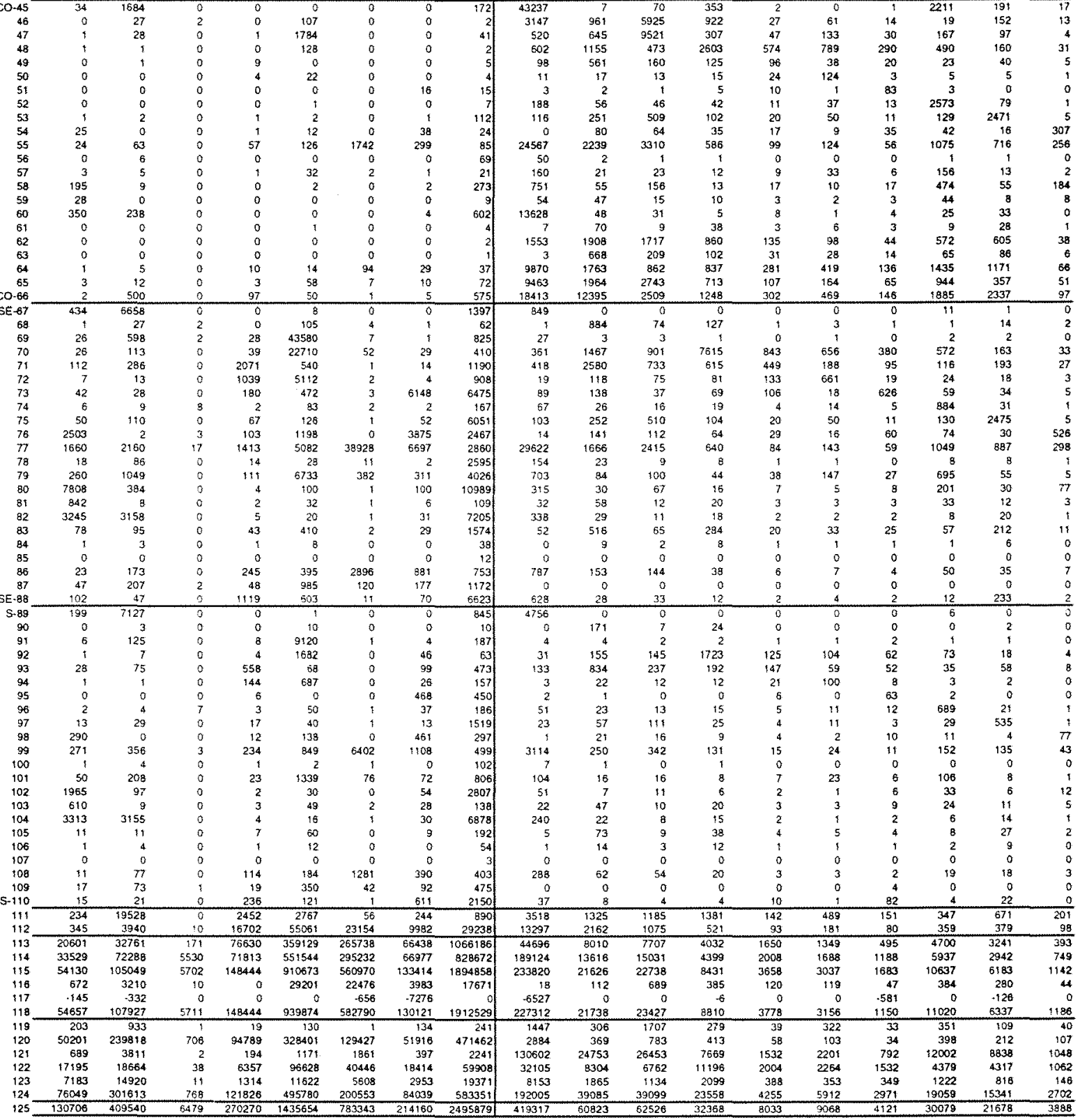


176

Matriz $1990 \cdot 5$ Regiós

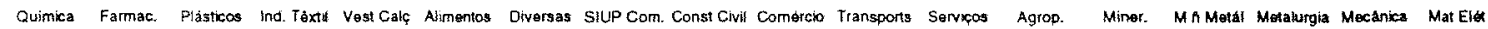
Agropecuátia

Minerais náo Motalicos Metalurgia

Matorial Elatirico

Matartal de Transporte

Madolita Mobiliario

Ind. da Borracha

Qu!mica

p.astsoos

Vastuario Calçados

industrias Diversas

SUP . Com..

Comprio

Transportas

Aervicos

Mineracáo

Minerales náa Metálicos

Motalusgiz
Mec anica

Material Elátrico.

Madelsa e Mobiliario

ind. da Borracha

Quinica

Plasticos

Ind, Toxti

Vestuário \& Catçados

indústrias ONer $3 a$

SHuP \& Com.

Comercio

Transport

Servicos

Minoração

Minerabis náo Metálicos

Motalurgia
Mecanica

Material Elátrico

Malorial de Transporte
Madoira o Mobitlario

Colulose, Papel o Grát.

Ind. da Borrach
Quimica

Famaciotic

Plásticos

Vestuário 9 Calçados Prod. Alimentafes

slup o Com.

Comercio

Fransportes

Sermess

Agropocuaria
Mineração

Minarałs náo Motállicos Metalurgia

Material Elátrico

Material de Transporte

Celutose. Papel $\bullet$ Grát.

ind da Borracha

Quimica

Plasticos

Vestuario o Calçados

Prod. Alimentares

SIUP a Com..

Construçăo
Comercio

Transporte

Servicos

Agropecuad

Minerais nảo Metálicos

Metalurgis

Mocanica
Material Elátrion

Material de Transporte

Celutuse. Papel a Grat.

ind. da Borracha

Quimica

Plásticos

Ind. Toxth

Prod. Allmentares

SIUP a Com..

Constructo

Transportes

Servicos

Impontaço

Impostos

Excedente Bruto

V.A. Custo de Falores

Impostos a/ Atividads Subsidios s/ Alividad

V.A. Preço Bdsico

Soma Linhas 23 a 44

som

Soma Linhas 67 a 88
Soma Linhas 89 a 110

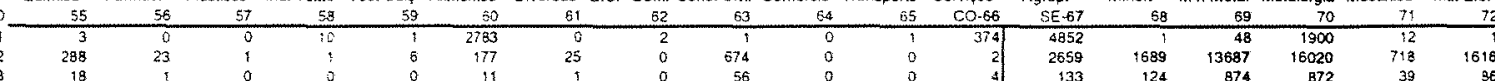

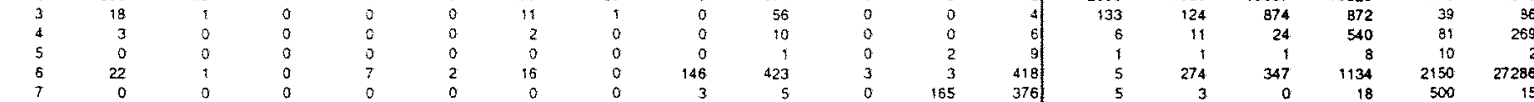

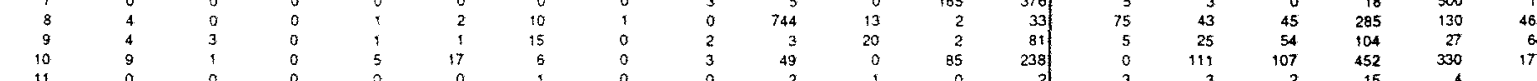
$L 118+L 124$ (Tol Gera)

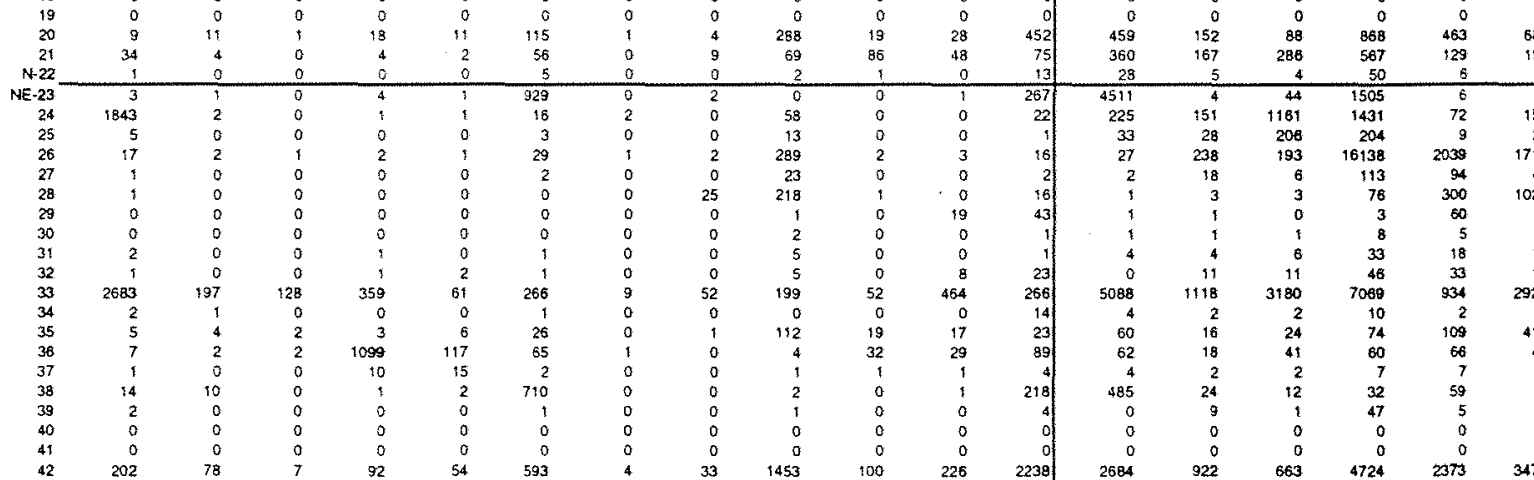

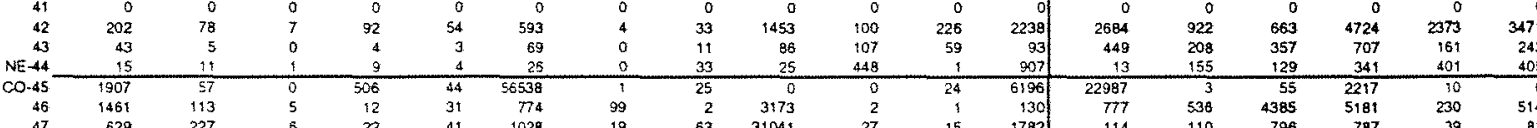

\begin{tabular}{|c|c|c|c|c|c|c|c|c|c|c|c|c|c|c|c|c|c|c|}
\hline & & & & & & & & & & & & & & & & & & \\
\hline 47 & 629 & 227 & 6 & 22 & 41 & 1028 & 19 & 63 & 31041 & 27 & 15 & 1782 & 114 & 110 & 796 & 787 & 39 & 81 \\
\hline 48 & 800 & 122 & 31 & 113 & $\varepsilon 4$ & 1233 & 41 & 85 & 12683 & 97 & 123 & 744 & 5 & 2 & 1 & 8 & 5 & 5 \\
\hline 49 & 263 & 15 & 4 & 45 & 8 & 121 & 1 & 221 & 488 & 79 & 27 & 189 & 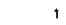 & 0 & 0 & 2 & 1 & 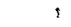 \\
\hline 50 & 25 & $z$ & 0 & 4 & 3 & 17 & 1 & 209 & 1895 & 13 & 5 & 241 & 1 & 0 & 0 & 1 & 1 & 9 \\
\hline 51 & 1 & 0 & 0 & 0 & 0 & $i$ & 0 & 6 & 25 & 0 & 359 & 690 & 0 & 0 & 0 & 0 & 0 & 0 \\
\hline 52 & 72 & 4 & 2 & 11 & 26 & 35 & 6 & 5 & 7292 & 105 & 19 & 335 & 21 & 12 & 13 & 86 & 40 & 142 \\
\hline 53 & 390 & 270 & 25 & 88 & 132 & 1365 & 13 & 178 & 231 & 1790 & 170 & 6821 & 1 & 0 & 0 & 2 & 1 & 2 \\
\hline 54 & 63 & 7 & 2 & 29 & 107 & 35 & 2 & 18 & 319 & 0 & 553 & 1287 & 0 & 0 & 0 & 0 & 0 & 0 \\
\hline 55 & $168 B B$ & 1044 & 325 & 904 & 236 & 2859 & 23 & 1062 & $653 t$ & 26068 & 10542 & 4160 & 6 & 2 & 2 & 13 & 7 & $\therefore$ \\
\hline 56 & 38 & 140 & 0 & 3 & 1 & 313 & 0 & 0 & $i$ & 0 & 0 & 1874 & G & 0 & 0 & 0 & ; & 0 \\
\hline 57 & 64 & 42. & 24 & 115 & 114 & 236 & 4 & 14 & 1108 & 161 & 168 & 234 & 0 & 0 & 0 & 1 & 0 & 1 \\
\hline 58 & 190 & 13 & 39 & 10719 & 6125 & 760 & 20 & 3 & 133 & 239 & $\$ 44$ & 2824 & 0 & 0 & 0 & 0 & 0 & 0 \\
\hline 59 & 46 & 4 & 2 & 178 & 688 & 57 & 2 & 10 & 45 & 15 & 11 & 175 & 2 & 9 & 2 & 17 & $\theta$ & 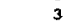 \\
\hline 60 & 792 & 413 & 1 & 10 & 398 & 17710 & 1 & 0 & 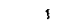 & 0 & 328 & 12970 & 2080 & 18 & 13 & 15 & 40 & 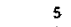 \\
\hline 61 & 139 & 7 & 1 & 11 & 18 & 38 & 1 & 25 & 90 & 5 & 4 & 244 & 0 & 0 & 0 & 0 & 0 & 0 \\
\hline 62 & 1466 & 170 & 53 & 442 & 877 & 1973 & 12 & 11336 & 1209 & 3352 & 894 & 13748 & 99 & 302 & 335 & 1299 & 312 & 217 \\
\hline 63 & 450 & 60 & 7 & $4 a$ & 24 & 257 & 3 & 779 & 26095 & $8+5$ & 803 & 17536 & 0 & 0 & 0 & 0 & 0 & 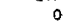 \\
\hline 64 & 1277 & 941 & 75 & 1242 & 764 & 7873 & 50 & 628 & 22200 & 2743 & 3241 & 34101 & 597 & 215 & 128 & 1252 & 683 & 973 \\
\hline 65 & 4052 & 422 & 33 & 335 & 244 & 5130 & 19 & 854 & 7266 & 7949 & 4983 & 8125 & 439 & 220 & 382 & 765 & 173 & 258 \\
\hline $10-68$ & 3431 & $\$ 412$ & 98 & 925 & 639 & 14327 & 194 & 10948 & 13791 & 39298 & 9112 & 164281 & 3044 & 2 & 32 & 999 & 4 & \\
\hline $5 E-67$ & $2 \$ 87$ & 2 & 0 & 0 & $\frac{2}{2}$ & 1096 & 0 & 0 & 9 & 0 & 1 & 224 & 193173 & 198 & 1873 & 30985 & 322 & 49 \\
\hline 68 & 6178 & 1 & 1 & 4 & 3 & 11 & 0 & 88 & 4 & 2 & $t$ & 71 & 1959 & 12780 & 8817 & 24978 & 835 & 1442 \\
\hline 69 & 12 & 2 & $:$ & 2 & : & 3 & 0 & 1 & 20 & 2 & 1 & 9 & 1445 & 5435 & 122169 & 19637 & 5970 & 18150 \\
\hline 70 & 998 & 110 & 18 & 96 & 85 & 1390 & 32 & 146. & 15175 & 124 & 141 & 922 & 2496 & 24021 & 16430 & 974975 & $\$ 8444 ?$ & 144971 \\
\hline 71 & 1256 & 68 & 20 & 207 & 43 & 556 & 6 & 992 & 2608 & 345 & 107 & 851 & 2728 & 40133 & 14070 & 89448 & 99860 & 40917 \\
\hline 72 & 125 & 5 & 2 & 19 & 10 & 53 & 4 & $11+7$ & 10058 & 55 & 17 & 1334 & 254 & 1943 & 1642 & 12331 & 30430 & 146663 \\
\hline 73 & 173 & 9 & 2 & 21 & 27 & 88 & 2 & 155 & 662 & 21 & 2619 & 5705 & 732 & 2260 & 903 & 10434 & 24016 & 4255 \\
\hline 74 & 36 & 3 & 2 & s & 12 & $\$ 1$ & 2 & 4 & 2531 & 41 & 8 & 131 & 974 & 729 & 722 & 4893 & 2016 & 6588 \\
\hline 75 & 398 & 270 & 25 & 88 & 134 & 1358 & 13 & 179 & 213 & 1791 & 167 & $6 a+7$ & 780 & 4719 & 11538 & 17991 & 5242 & 12951 \\
\hline 76 & 122 & 13 & 5 & 54 & 187 & 54 & 3 & 32 & 558 & 1 & 950 & 2227 & 106 & 2076 & 2011 & 8803 & 6106 & 3054 \\
\hline 77 & 12526 & 356 & 495 & 1369 & 345 & 1839 & 35 & 545 & 4859 & 10603 & $\$ 110$ & 2928 & 202207 & 29869 & 52365 & 98945 & 21145 & 32513 \\
\hline 78 & 134 & 149 & 1 & $: 0$ & 5 & 165 & 0 & 9 & 21 & 4 & 2 & 1954 & 1078 & 391 & 189 & 1252 & 182 & 231 \\
\hline 79 & 261 & 197 & 108 & $: 23$ & 278 & 1015 & 13 & 59 & 5014 & 723 & 737 & 377 & 4508 & 1345 & 1952 & 6503 & 8731 & 32505 \\
\hline $\mathrm{BO}$ & 103 & 3 & 17 & 4467 & 2559 & 326 & 9 & t1 & 74 & 102 & 229 & 1224 & 2607 & 597 & 4656 & 2568 & 2169 & $\$ 405$ \\
\hline 91 & $; 0$ & 7 & 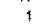 & 10 & 500 & 38 & 2 & 14 & 67 & 9 & 4 & i42 & 251 & 1091 & 278 & 3255 & 338 & 685 \\
\hline 82 & 553 & 74 & , & 13 & 28 & 4033 & 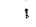 & 14 & 18 & 45 & to & 2460 & 47854 & 1057 & 681 & 3728 & 1860 & 892 \\
\hline 83 & 1044 & 49 & $\gamma$ & 56 & 135 & 258 & 9 & 159 & 386 & 23 & 23 & 1782 & 352 & 8085 & 1362 & 41514 & 4603 & 7196 \\
\hline 84 & 22 & 1 & 0 & 2 & 3 & 7 & 0 & 2 & a & 0 & 0 & 42 & 6698 & 20383 & 22455 & 88025 & 20996 & 14744 \\
\hline 85 & 0 & 0 & 0 & 0 & 0 & 0 & 0 & 0 & 0 & 0 & 0 & ol & 5 & 3030 & 1142 & 4321 & 2021 & 1745 \\
\hline 86 & 376 & 33 & 5 & 21 & 12 & 129 & 1 & 89 & 446 & 581 & 656 & 584 & 28938 & 12019 & 8479 & 54271 & 26694 & 38397 \\
\hline 87 & $i$ & 0 & 0 & 0 & 0 & 0 & 0 & 0 & 0 & 0 & 0 & 3) & 35015 & 17699 & 30485 & 61131 & 13876 & 20688 \\
\hline$S E \cdot 8 a_{-}$ & 134 & 33 & 4 & 52 & 4 & 81 & 1 & 18 & 26 & 103 & 45 & 608 & 18504 & 59826 & 14985 & 50639 & 21285 & 32353 \\
\hline$\$ .89$ & 97 & 0 & 5 & 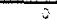 & & 1474 & 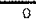 & 9 & - & 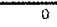 & 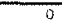 & & 58530 & 10 & 199 & 6884 & & \\
\hline 9 & $6 \mathrm{~S}$ & 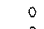 & Q & & & & 0 & 8 & & & 0 & 12 & & 18 & 151 & . & & 18 \\
\hline
\end{tabular}

\begin{tabular}{|c|c|c|c|c|c|c|c|c|c|c|c|c|c|c|c|c|c|c|}
\hline 90 & 590 & 0 & 0 & $y$ & t & $f$ & 0 & 8 & . & 0 & 0 & 12 & & 18 & 151 & 178 & g & \\
\hline 91 & 4 & 0 & 0 & i & 0 & 2 & 0 & 2 & 27 & 1 & 2 & 18 & 54 & 53 & 397 & 379 & 16 & 36 \\
\hline 92 & 111 & 12 & 2 & 9 & $y$ & 139 & 5 & 12 & 1750 & 10 & 39 & 136 & 0 & 0 & 0 & 0 & 0 & 1 \\
\hline 93 & 389 & 21 & $\delta$ & So & 11 & 172 & 2 & 318 & 777 & 112 & 90 & 450 & 0 & 0 & 0 & 1 & 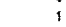 & $i$ \\
\hline 94 & 17 & 3 & 0 & 3 & : & 8 & 1 & 169 & 1516 & 8 & 17 & 211 & 0 & 0 & 0 & 1 & 0 & $i$ \\
\hline 95 & 0 & 0 & 0 & 0 & 0 & 0 & 0 & 4 & 9 & 0 & 269 & 527 & 0 & 0 & 0 & 0 & 0 & 0 \\
\hline 96 & 22 & I & 1 & 3 & 8 & 30 & 2 & 3 & 1997 & 30 & 26 & 171 & 314 & 189 & 205 & $\$ 314$ & 611 & 2195 \\
\hline 97 & 93 & 59 & 6 & 20 & 30 & 295 & 3 & 40 & 53 & 387 & 37 & 1481 & 0 & 0 & 0 & 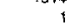 & 0 & 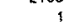 \\
\hline 98 & 17 & 2 & $i$ & 3 & 27 & 9 & 0 & 5 & 83 & 0 & 146 & 340 & 0 & 0 & 0 & 0 & 0 & 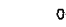 \\
\hline 99 & 1656 & 136 & 71 & 199 & 54 & 267 & 5 & 79 & 722 & 1409 & 698 & 456 & 10 & 2 & 6 & 15 & 6 & 8 \\
\hline 100 & 6 & 5 & 0 & 0 & a & 6 & 0 & 1 & i & 0 & 0 & 70 & 3 & 0 & 0 & 1 & 0 & 0 \\
\hline tor & 40 & 28 & 16 & 19 & 41 & 154 & 2 & 10 & 772 & 109 & 117 & 145 & i & 1 & 1 & 4 & 2 & 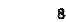 \\
\hline 102 & 22 & 2 & 3 & 709 & 407 & 54 & 1 & 5 & 20 & 17 & 5.3 & 248 & i & 1 & 0 & 4 & t & 2 \\
\hline 103 & 64 & 6 & t. & 6 & 327 & 31 & 1 & 11 & 65 & 8 & 15 & 159 & 46 & 182 & 43 & 362 & 138 & 72 \\
\hline 104 & 108 & 44 & 1 & 7 & 18 & 1290 & 1 & 10 & 15 & 18 & 4 & 890 & 20562 & 204 & 185 & 221 & 519 & 79 \\
\hline 105 & 135 & \% & $t$ & $: 1$ & 17 & 35 & $i$ & 22 & 75 & 3 & 6 & 238 & 1 & 0 & , & 2 & 0 & 10 \\
\hline 106 & 34 & $z$ & 0 & 4 & 5 & 11 & 0 & 3 & 13 & 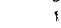 & $i$ & 55 & 314 & 962 & 1066 & 4133 & 992 & 691 \\
\hline 107 & 0 & 0 & 0 & 0 & 0 & 0 & 0 & 0 & 0 & 0 & 0 & 0 & 4 & 10 & 7 & 59 & 24 & 36 \\
\hline 108 & 144 & 13 & 2 & 9 & 7 & 52 & 1 & 35 & 170 & $2 \div 2$ & 240 & 262 & $\$ 501$ & 543 & 321 & 3148 & 1662 & 2437 \\
\hline 109 & i & 0 & 0 & 0 & 0 & 0 & 0 & 0 & 1 & 0 & 17 & 59 & 631 & 820 & 1420 & 2845 & 644 & 960 \\
\hline S. 110 & 13 & 3 & 0 & 5 & 4 & $\mathrm{~B}$ & 0 & a & 25 & 10 & 345 & 1069 & 64 & 3 & 3 & 30 & 5 & 8 \\
\hline 111 & 20589 & 1458 & 66 & 1286 & 5.16 & 3686 & 21 & 4058 & 5316 & 2202 & 10310 & 9674 & 11778 & 9936 & 11362 & 107767 & 18099 & 56786 \\
\hline 112 & 3020 & 392 & 52 & $\begin{array}{r}556 \\
\end{array}$ & $3+2$ & 6442 & 29 & 3674 & 60907 & 1004 & 6684 & 45019 & 44525 & 96214 & 10309 & 40659 & 11868 & 20975 \\
\hline$\$ 13$ & 10464 & 1791 & 505 & 3243 & 4156 & 14487 & 237 & 23764 & 40111 & 67545 & 23746 & 628917 & 149662 & 60068 & 73896 & 314652 & 211004 & 156775 \\
\hline 114 & 32117 & $\$ 237$ & 338 & $9 \div 15$ & 4489 & 22077 & 400 & 19996 & $\$ 15833$ & $\begin{array}{r}03555 \\
+035\end{array}$ & 29815 & 459722 & 633274 & 102099 & 144125 & 343311 & 256822 & 196100 \\
\hline 115 & 42581 & 5027 & 1342 & 12358 & 8645 & 36565 & 637 & 43758 & 155944 & 178099 & 53561 & 1088639 & 782936 & 162167 & $2+8021$ & 657983 & 467820 & 352875 \\
\hline 116 & 1572 & 188 & 42 & 447 & $34 t$ & 2044 & 19 & 1647 & 4067 & 3663 & 1605 & 24892 & 30 & 238 & 6611 & 30042 & 15373 & 13860 \\
\hline 117 & & 0 & 0 & -279 & .155 & .226 & 0 & .162 & & .912 & .3503 & & -21854 & 0 & 0 & -459 & & \\
\hline 118 & 44152 & 6215 & 1385 & 12526 & 8831 & 38383 & 650 & 45245 & 160010 & 173850 & 51664 & 1513530 & 761111 & 163005 & 224832 & 687547 & 483199 & 366735 \\
\hline 118 & 386 & 47 & 3 & 53 & 50 & 2151 & 28 & 183 & 2580 & $: 15$ & 220 & 1929 & 6313 & 2539 & 12843 & 20403 & 447 & 33389 \\
\hline 120 & 4790 & 352 & 160 & 1754 & 299 & 2193 & 21 & 164 & 3136 & 737 & 905 & $4 \leqslant 29$ & 12582 & 3065 & 5893 & 30264 & 6717 & 10697 \\
\hline 321 & 34109 & 5373 & 712 & 14997 & 9362 & 115828 & 498 & 26756 & $\$ 23683$ & 84012 & 30913 & 280735 & 3642 & 1122 & 4133 & 10916 & 1245 & 1668 \\
\hline 122 & 27334 & 2082 & 736 & 7087 & 4756 & 11286 & 148 & 3406 & 53150 & 13891 & 11134 & 2977 & 462415 & 249806 & 321127 & 1897108 & 483893 & 561382 \\
\hline 123 & 3533 & 313 & 94 & $\lcm{247}$ & 1907 & 3742 & 25 & 684 & $B 779$ & 1821 & 1833 & 6461 & 89727 & 3150 & 3978 & 20809 & 48.15 & 6227 \\
\hline 124 & 93760 & 10017 & 1823 & 27080 & 16433 & 145527 & 770 & 38925 & 257549 & 112820 & 62001 & 377719 & 663782 & 285833 & 369645 & 1847927 & 530897 & 691123 \\
\hline $125^{\circ}$ & 37912 & 76232 & 3207 & 33606 & 25264 & 183910 & 1426 & 84169 & 417560 & 286670 & 113664 & 1491249 & 1424893 & 449838 & 59427 & 2535474 & 1014096 & 105785 \\
\hline
\end{tabular}


Material Elático

Material de Transoonto

Colulose, Papela a Grál.

Ind.da Borractia

Farmacautica

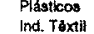

Vastuario Cakcados Prod. Almentares
Indistrias DNersas

StuP \& Com.

Construçáo
Comarcio

Transpontos

Servicas

Mineracáa

Minerals náo Metallicos Metalurgia
Mecanica

Matorial Elátrico

Matortal de Transports

Celubse, Papel o Grát.

ind, da Bortacha

Farmacautica

\section{Plasticos}

Vestudito 8 Calcados

Industrias DNersas

Sonstruçato Civa

Comercio

Transport
Servicos

Agropocuária

Mineraçăo Meaturgia Mecanica
Matertal Elétrico

Matertial de Transporto

Madrira o Mobiliano
Cotubse. Papel a Grat.

hod. da Borracha

Quinica

Farmacà

Ind. Téxti

Vestuário o Calcácos Prod. Alimentares

Indústrias Diver
SIUP $*$ Com..

Construçáa

Transictortas

Servicos

Agropecuária

Mineraçào Matatugra

Mecătica
Material Elátrico

Material de Transporte Madeira a Mobiliáno Colulosa, Papel a Gral. Ind da Borracha Quimica Piásticos
Ind. Táxti

Cakados Prod. Alimentares Induistnas DNorsas Construçá CN Comercio Transportis
Serviços Impontaçoos Impostos Remuneraçós Excedente Bruto Impostos a Atividad Subsidios s/ Alvidaco V.A. Pteço Basico

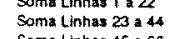
soma Linhas 45 5. 66

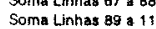
Soma Limhas I a 112
$L 118+L$
124

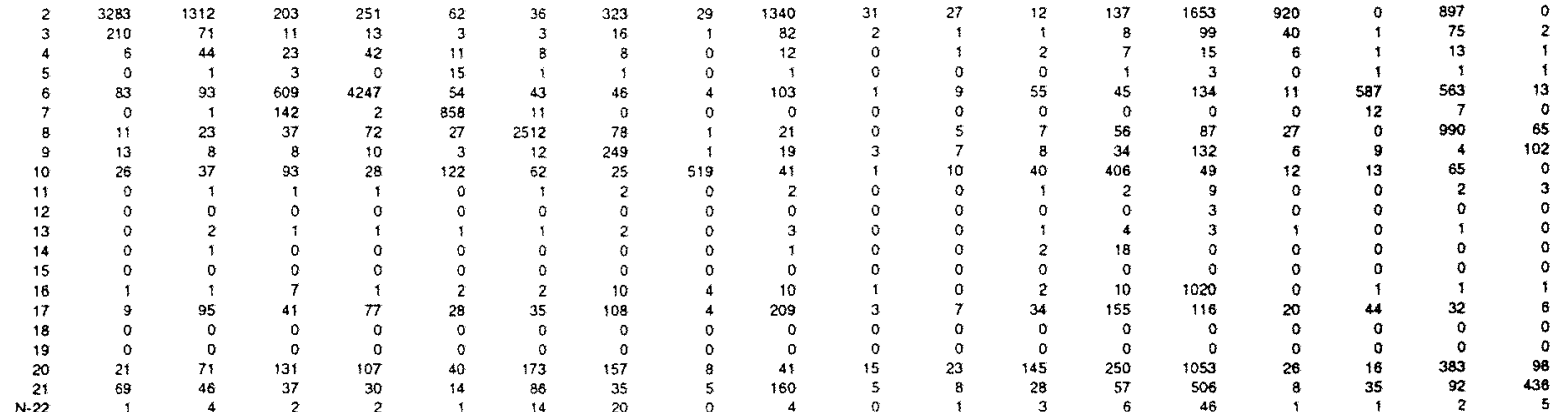

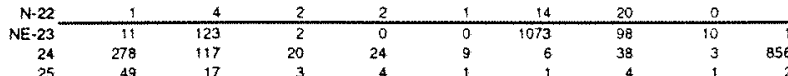

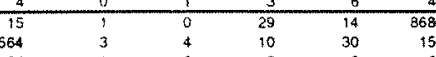
156

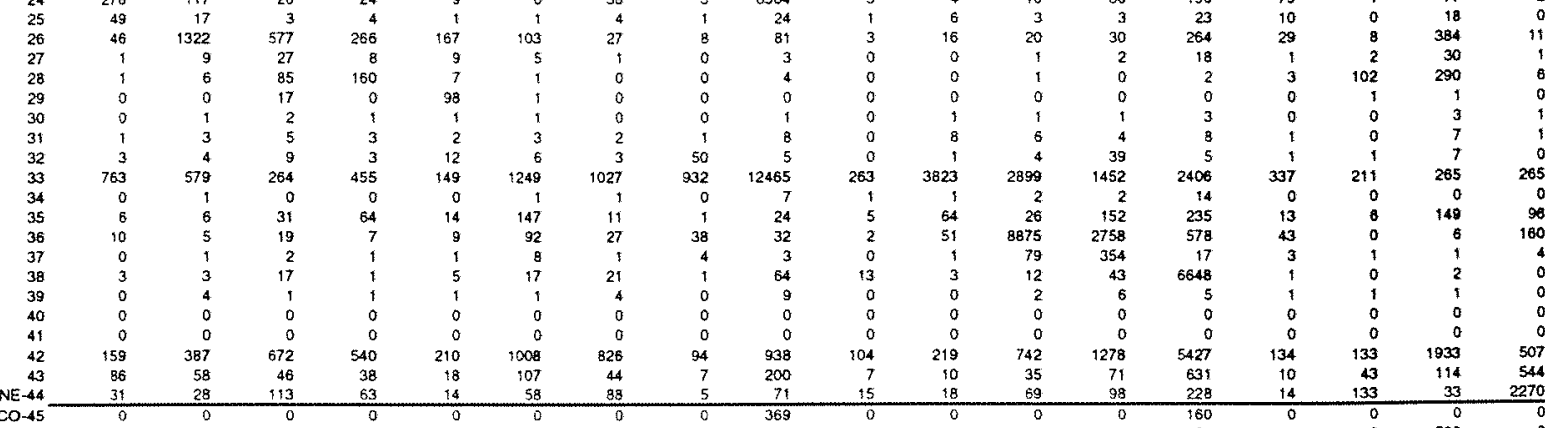

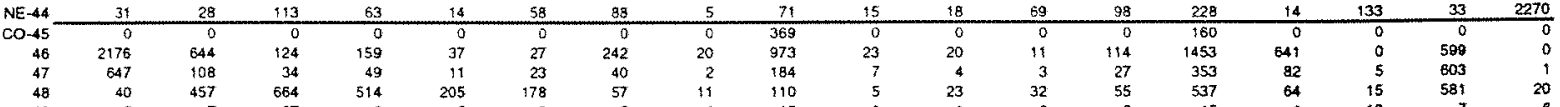

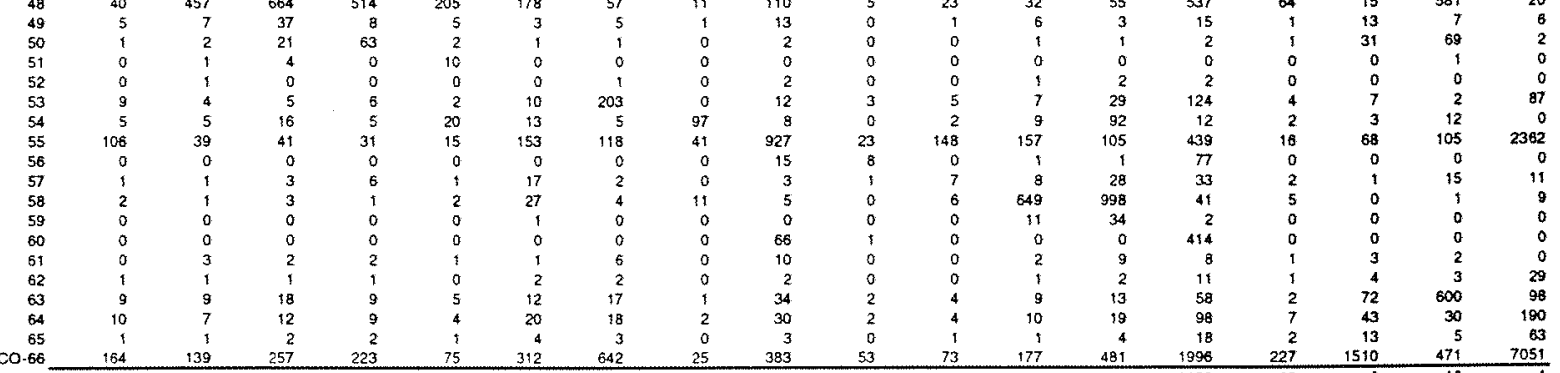

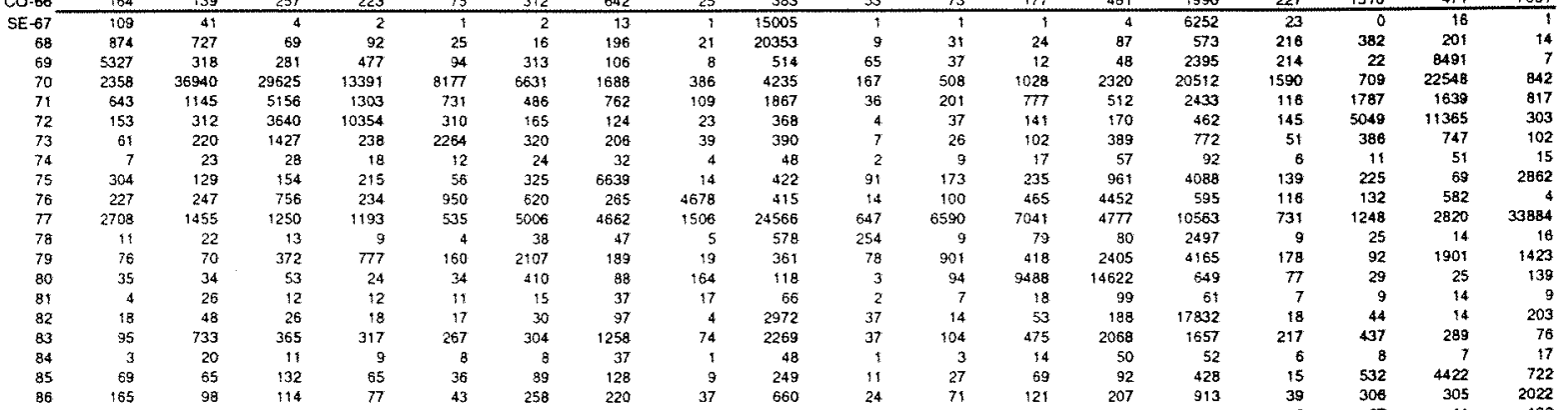

\begin{tabular}{|c|c|c|c|c|c|c|c|c|c|c|c|c|c|c|c|c|c|c|}
\hline & & & & & & & & & & & & & & & & & & \\
\hline$E-88$ & 887 & 756 & $13 \pi 7$ & 1996 & 408 & 1680 & 3996 & 341 & 2304 & 302 & 434 & 1057 & 2788 & 10789 & 1212 & 7981 & 2495 & 37303 \\
\hline S-89 & 298 & 1669 & 15 & 4 & 5 & 22187 & 1928 & 182 & 3750 & 9 & 2 & 5225 & 756 & 322217 & 59 & 124 & 59 & $\sqrt{3}$ \\
\hline 90 & 755 & 906 & 67 & 84 & 30 & 23 & 197 & 17 & 16974 & 8 & 26 & 51 & 139 & 535 & 196 & 257 & 182 & 28 \\
\hline 91 & 26886 & 1054 & 1650 & 2622 & 688 & 1775 & 378 & 26 & 1574 & 336 & 167 & 54 & 190 & 11752 & 569 & 179 & 47018 & 48 \\
\hline 92 & 2462 & 53799 & 28365 & 13874 & 8606 & 5639 & $\$ 499$ & 300 & 3529 & 130 & 448 & 722 & 1475 & $\$ 3978$ & 1614 & 463 & 17162 & $55:$ \\
\hline 93 & 3934 & 6172 & 31349 & 7045 & 6597 & 2455 & 4367 & 593 & 10993 & 194 & 1201 & 4781 & 2212 & 12622 & 537 & 10945 & 6776 & 4996 \\
\hline 94 & 228 & 432 & 4980 & 13068 & 1052 & 242 & 161 & 32 & 510 & 6 & 52 & 215 & 153 & 650 & 180 & 8410 & $\$ 4313$ & 417 \\
\hline 95 & 1 & 14 & 1332 & 18 & 7845 & 115 & $\uparrow$ & $i$ & 4 & 0 & 0 & 2 & 3 & 8 & 2 & 135 & 72 & 1 \\
\hline 96 & 241 & 494 & 1183 & 1362 & 1579 & 48067 & 1635 & 41 & 664 & 16 & 167 & 272 & 1517 & 2874 & 504 & 115 & $\$ 7299$ & 1357 \\
\hline 97 & 2161 & 926 & 1109 & 1546 & 404 & 2349 & 47234 & 100 & 3002 & 649 & 1236 & 1681 & 6877 & 29139 & 991 & 1599 & 520 & 20375 \\
\hline 9 & 279 & 304 & 972 & 293 & $136 t$ & 765 & 324 & 5725 & 501 & 17 & 118 & 566 & 5443 & 733 & 141 & 167 & 722 & 8 \\
\hline 99 & 6582 & 4442 & 3510 & 3075 & 1595 & 11448 & 10637 & 3298 & 53373 & 1381 & 13648 & 14827 & $\{0979$ & 25538 & 1658 & 3405 & 7144 & 82827 \\
\hline 100 & 8 & 18 & 11 & 7 & 4 & 29 & 37 & 3 & 175 & 54 & 6 & 34 & 62 & 581 & $\theta$ & 30 & 13 & 20 \\
\hline 101 & 272 & 279 & 1480 & 2775 & 729 & 7469 & 626 & 59 & 1211 & 268 & 3082 & 1410 & 8292 & 14491 & 617 & 342 & 6744 & 4946 \\
\hline 902 & 235 & 207 & 468 & 160 & 749 & 2868 & 533 & 1132 & 713 & 18 & 642 & 65504 & 100997 & $\$ 491$ & 520 & 172 & 208 & 955 \\
\hline 103 & 145 & 588 & 611 & 307 & 1059 & 1265 & 795 & 400 & 1584 & so & 177 & 478 & 44592 & 2433 & 303 & 320 & 503 & 316 \\
\hline 104 & 272 & 583 & 595 & 270 & 297 & 834 & 1482 & 52 & 4671 & $79:$ & 179 & 754 & 11905 & 230893 & 248 & 429 & 375 & 1446 \\
\hline 105 & 174 & 1277 & 854 & 618. & 579 & 581 & 2110 & 144 & 3819 & 61 & 168 & a11 & 3511 & 2949 & 366 & 781 & 710 & 154 \\
\hline 106 & 4263 & 4478 & 4438 & 1877 & 993 & $\$ 991$ & 7397 & 429 & 7085 & 252 & 1523 & 5025 & 6086 & 26005 & 634 & 57964 & i571 & 21448 \\
\hline 107 & 290 & 304 & 602 & 335 & 172 & 452 & 629 & 47 & 1068 & 62 & 127 & 397 & 526 & 2504 & 80 & 2047 & 17105 & 2928 \\
\hline 108 & 2483 & 3895 & 7884 & 6490 & 2408 & 13404 & 12027 & 760 & 7554 & 1124 & 2059 & 11840 & $\$ 9898$ & 90986 & 1916 & 3453 & 24682 & 22058 \\
\hline 109 & 5769 & 2898 & 2957 & 2448 & 1544 & 8277 & 3369 & 469 & 14036 & 500 & 788 & 3099 & 6047 & 59589 & 707 & 3568 & 7832 & 44307 \\
\hline $5-110$ & 1960 & 1729 & 5096 & 2725 & 11040 & 3964 & 9253 & 316 & 4788 & 642 & 939 & 2524 & 6521 & 24462 & 2658 & 17805 & 5665 & 81299 \\
\hline 111 & 2634 & 8744 & 5058 & 9150 & 3663 & 3113 & 6436 & 1945 & 70929 & 1629 & 1584 & 8037 & 9987 & $30: 22$ & 653 & 18654 & 6608 & 8642 \\
\hline 112 & 2390 & 3299 & 3317 & 3380 & 1947 & 3223 & 3633 & 944 & 10402 & 438 & 1249 & 4097 & 5712 & 16027 & 905 & 16888 & 75716 & 39404 \\
\hline 113 & 17130 & 25529 & 58969 & 25262 & 12053 & 42192 & 31107 & 3798 & 36047 & 2001 & 12134 & 20269 & 76076 & 109618 & 7380 & 109237 & 49864 & 265060 \\
\hline$\$ 14$ & 33410 & 27854 & 71774 & 31599 & 28961 & 53299 & 23240 & 7236 & 110642 & 4734 & $20 \div 33$ & 56970 & 82180 & 160538 & 12479 & 91915 & 143996 & 408372 \\
\hline 115 & 50539 & 53384 & 130743 & 56861 & 41020 & 95491 & 59347 & 19034 & 146689 & 6735 & 32267 & 77239 & 158258 & 270156 & 19851 & 201153 & 193858 & 671432 \\
\hline 116 & $\{532$ & 2437 & 4296 & 2233 & 1145 & 3443 & 2686 & 427 & 5414 & 210 & 1015 & 2793 & 6248 & 15509 & 598 & 7571 & 5055 & 14370 \\
\hline 117 & 0 & -37 & 0 & 0 & $-14+53$ & 0 & .1209 & 0 & 0 & 0 & 0 & .1744 & -2838 & -1491 & 0 & .744 & 0 & .3581 \\
\hline 118 & 52072 & 55784 & $\begin{array}{r}+35039 \\
\end{array}$ & 59095 & 28014 & 98934 & 60824 & +1460 & 152103 & 6945 & 33282 & 78288 & 161667 & 284976 & 20448 & 207980 & 198915 & 682227 \\
\hline 119 & 3593 & 1850 & 1320 & 5697 & 793 & 3377 & 1259 & 495 & 1823 & 64 & 103 & 376 & 1052 & 21917 & 1004 & 700 & 2994 & 659 \\
\hline 120 & 1648 & 2744 & 1984 & 1825 & 800 & 3833 & 2440 & 1328 & 22643 & 486 & 5118 & 12462 & 6246 & 22267 & 755 & 627 & 3639 & 4212 \\
\hline 121 & 2427 & 1008 & 8.33 & $77 \theta$ & 272 & 724 & 1432 & 202 & 2955 & 123 & 317 & 947 & 1739 & 5095 & 878 & 1803 & 2450 & 11886 \\
\hline 122 & 16828 & 48688 & 47333 & 32609 & 15487 & 19718 & 21508 & 7859 & 81971 & 1957 & 10254 & 20447 & 35037 & 87353 & 5587 & 17357 & 63567 & 88286 \\
\hline 123. & 57705 & $8: 702$ & 97536 & 57732 & 48415 & 140467 & 105574 & 13463 & 137838 & 6415 & $2496 B$ & $+220+8$ & 240053 & 892787 & 14231 & 112832 & 171580 & 282889 \\
\hline 124 & 87225 & 148013 & .157380 & 111170 & 71398 & 174454 & 142282 & 26237 & 328461 & 11108 & 43593 & 188385 & 299828 & 1075568 & 24010 & 168BGe2 & 328554 & 433978 \\
\hline 1 & 139297 & 203797 & 292419 & 170264 & 99410 & 273389 & 203906 & 37697 & 480564 & 99053 & 76875 & 246674 & 461493 & 1359742 & 44458 & 376842 & 525.468 & 1116205 \\
\hline
\end{tabular}


Transports Servicos Dumfin Consumo FBCF Var Estq Export Dum Fin Consumo FBCF Var Esta Export Durm Fin Consumo FBCF Var Esta Export Dum Fin Agropecuatia Minerąia náa Motálicos Motalurgia

Matarial Elatrico Materlat do Transports Caluluse. Papel a Grat. Ind. da Borracha
Quimica Farmacoutica Plásticos Vestuário o Calcados Prod. Altmemares Siup o Com.
Construçáa Cill Comércio Iransportes
Servicos Agropecuaria Mineraçăó Metaiurgia Material Eigtrico Materlal de Transporte
Madeika o Mootlario Colutose, Papel a Grát. Ind. da Borrache Qumacouric Plasstcos
Ind. Téxtii Vestuátlo o Calçados Industrias DNarsa SIUP * Com..
Construçán Civit Comprcio Transporte Agropecuat Minerals nao Motáticos Metalurgia Mocantica
Material Elatrico Material de Transponte Colulose, Papol o Grát Ind. da Borracha Fuimica Plasticos Vestuario a Calçados Prod. Alimentares
Industrias Diversas SIUP a Com.. Construçá
Comercio Transporte Sorviços Agropocuár Minnerails náo Motálicos Motaiurgia

Macinica Material de Transporte Cotuluse. Papel Gio Ind, da Borracha

Farmacéutica

Píasticos

Vostuário a Calçados Prod. Alimentar sos Indistrias Diversa SIUP a Com..

Comercio Transportes Agropocuátia Mtrowaçáa Minerais năo Motálicos Metalurgia Matederial Éatrico Material de Transporte Celulose. Paptian Grát. ind. da Borrach

Farmacóutica

Plásticos

ind Toxtil Prod. Alimentar Siup a Com. Comstruçáo Transpont Serviços Import açöes Remuneracoes Excodente Bruto V.A. Custo de Falor
Impostos al Atvidado Impostos a/ Atvivd ado V.A Proç Básico Soma Linhas 1 a 2 Soma Linhas 23 a 44 Sorna Limhas 67 a 88 Som Linhas 89 a 110
Soma Linhas 1 a 112

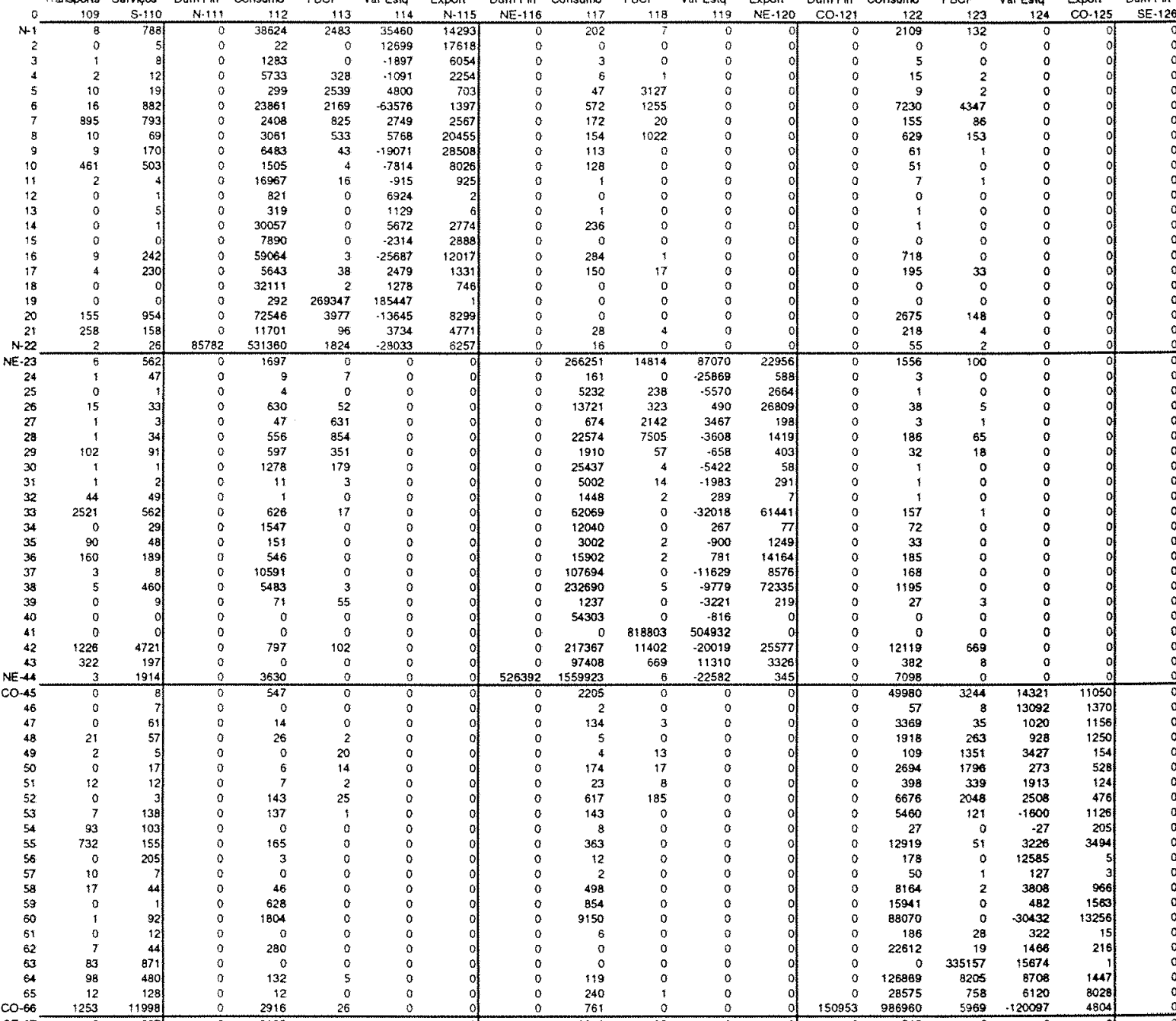
L $118+L 124$ (Tot Gora

\begin{tabular}{|c|c|c|c|c|c|c|c|c|c|c|c|c|c|c|c|c|c|c|}
\hline$C 0-66$ & 1253 & 11998 & 0 & 2916 & 26 & 0 & of & 0 & 761 & 0 & 0 & 0 & 150953 & 986960 & 5969 & .12000 & 4804 & \\
\hline$S E-67^{\circ}$ & $\overline{2}$ & 227 & 0 & 3102 & 4 & 0 & 0 & 0 & 13248 & 32 & 0 & 0 & $\overline{0}$ & 1543 & 6 & & 0 & \\
\hline 58 & 4 & 112 & 0 & 27 & 21 & 0 & of & 0 & 361 & 0 & 0 & o & 0 & 200 & 27 & & 0 & \\
\hline 69 & 2 & 595 & 0 & 353 & i & 0 & of & 0 & 3113 & 87 & 0 & 0 & 0 & 18 & ; & & o & 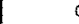 \\
\hline 70 & 869 & 2327 & 0 & 2785 & $40 \div$ & 0 & of & 0 & 1487 & 114 & 0 & 0 & 0 & 2652 & 531 & & 0 & \\
\hline 31 & 232 & 979 & 0 & 249 & 9122 & 0 & of & 0 & 2515 & 5703 & 0 & 0 & 0 & 715 & 12302 & & 0 & \\
\hline 72 & 70 & 2689 & 0 & 1023 & 2493 & 0 & of & 0 & 30022 & 3110 & 0 & 0 & 0 & 10234 & 7367 & & 0 & \\
\hline 73 & 2608 & 3365 & 0 & 12756 & 4595. & o & of & 0 & 45020 & 14806 & 0 & 0 & 0 & 15383 & 12784 & & 0 & \\
\hline 74 & a & 64 & 0 & 2462 & 443 & 0 & o] & 0 & 10636 & 3167 & 0 & 0 & 0 & 2163 & $\infty 67$ & & 0 & \\
\hline 75 & 232 & 4527 & 0 & $593 t$ & 53 & 0 & of & 0 & 6288 & 1 & 0 & 0 & 0 & 4227 & 89 & & 0 & \\
\hline 76 & $\triangle 4 B 8$ & 5022 & 0 & 15 & 3 & 0 & o & 0 & 625 & i & 0 & 0 & 0 & 61 & 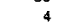 & & 0 & c \\
\hline$\pi$ & 12667 & 3785 & 0 & 4844 & 89 & 0 & o & 0 & 12930 & 4 & 0 & o & 0 & 7966 & 115 & & 0 & \\
\hline 79 & 5 & 6572 & 0 & 8178 & 5 & 0 & of & 0 & 35830 & 0 & 0 & 0 & 0 & 14132 & 6 & & 0 & \\
\hline 79 & 1256 & 732 & 0 & 791 & 9 & 0 & of & 0 & 2489 & 15 & 0 & 0 & 0 & 1480 & 14 & & 0 & \\
\hline BO & 260 & 707 & 0 & 2206 & 4 & 0 & o] & 0 & 22425 & 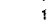 & $a$ & 0 & 0 & $394 \%$ & 5 & & 0 & \\
\hline 35 & 9 & 62 & 0 & 22449 & 3 & 0 & d) & 0 & 30036 & 0 & 0 & 0 & 0 & $\$ 5559$ & 4 & & 0 & \\
\hline B2 & 45 & 4253 & 0 & 26725 & 20 & 0 & of & 0 & 86096 & 1 & 0 & o & a & 12538 & 25 & & 0 & \\
\hline 83 & 75 & 2633 & 0 & 354 & 309 & 0 & 0 & 0 & 5524 & 8 & 0 & 0 & 0 & $305 \%$ & 397 & & 0 & \\
\hline 84 & 5 & 85 & 0 & 5828 & 8 & 0 & of & 0 & 153 & 0 & 0 & 0 & 0 & 85 & 10 & & 0 & \\
\hline 25 & 614 & 6422 & 0 & 0 & 0 & 0 & of & 0 & 0 & 0 & 0 & 0 & 0 & 0 & 0 & & 0 & \\
\hline 86 & 1708 & 2094 & 0 & 2548 & 99 & 0 & of & 0 & 5723 & 0 & 0 & 0 & 0 & 2453 & 35 & & 0 & \\
\hline 87 & 24 & 271 & 0 & 37 & 3 & 0 & of & 0 & 6628 & 40 & 0 & 0 & 0 & 4 & 1 & & 0 & \\
\hline SE. 88 & 5623 & 63746 & 0 & 34445 & 329 & 0 & of & 0 & 2335 & 10 & 0 & 0 & 0 & 945 & 23 & & & 3023 \\
\hline 5.89 & 139 & 13405 & 0 & 1789 & $\overline{2}$ & 0 & का & 0 & 8887 & 77 & 0 & 0 & 0 & 634 & 3 & & & \\
\hline
\end{tabular}

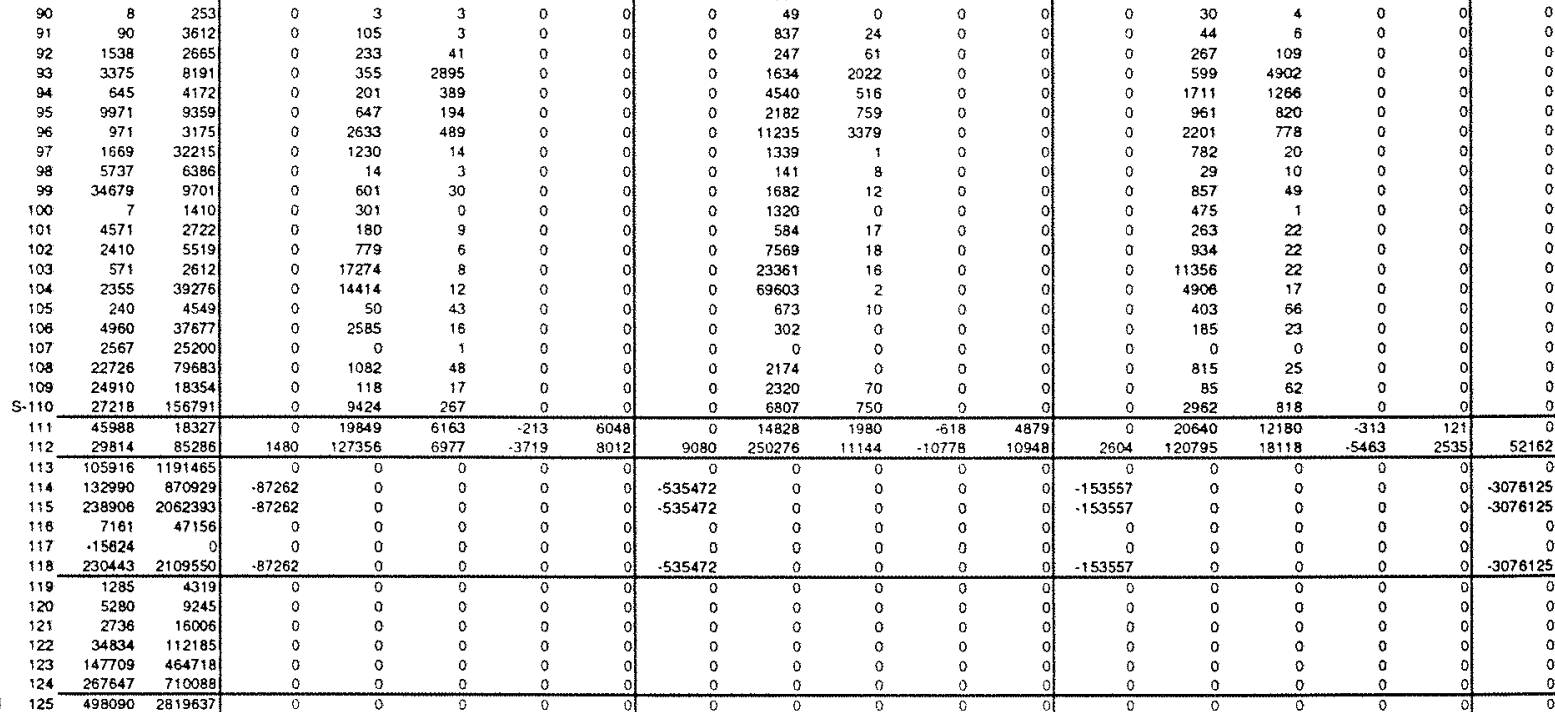




\begin{tabular}{|c|c|c|c|c|c|c|c|c|c|c|c|c|c|c|c|c|c|c|}
\hline $0-5$ Re & & & & & & & & & & & & & & 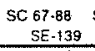 & & & & \\
\hline 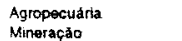 & 2 & & & & of & 0 & 5491 & & $\overline{0}$ & 可 & $\begin{array}{l}69883 \\
12197 \\
\end{array}$ & $\begin{array}{l}1.336 \\
1.69 \\
140\end{array}$ & $\begin{array}{l}\frac{4508}{4508} \\
3640\end{array}$ & $\begin{array}{l}\frac{133956}{59842} \\
5\end{array}$ & $\begin{array}{l}322389 \\
23560\end{array}$ & $\begin{array}{l}50850 \\
30339 \\
03\end{array}$ & 209 & 2221 \\
\hline 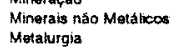 & 3 & 年 & & & & 0 & $\begin{array}{l}12 \\
40\end{array}$ & 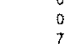 & $\begin{array}{c}0 \\
0 \\
0\end{array}$ & a & $\begin{array}{l}21035 \\
27075 \\
27074\end{array}$ & $\begin{array}{l}146 \\
29 \\
28\end{array}$ & $\begin{array}{l}2019 \\
239 \\
239\end{array}$ & 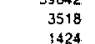 & $\begin{array}{r}752 \\
721\end{array}$ & $\begin{array}{l}54040 \\
7224\end{array}$ & $\frac{3}{7}$ & $\begin{array}{r}5 \\
17\end{array}$ \\
\hline 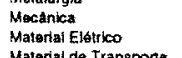 & 5 & $\begin{array}{r}89 \\
68936 \\
684367\end{array}$ & $\begin{array}{l}34 \\
86802 \\
81020\end{array}$ & $\vdots$ & of & $\vdots$ & $\begin{array}{r}24 \\
18823 \\
1882\end{array}$ & $\begin{array}{l}14250 \\
14203 \\
\end{array}$ & 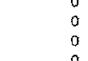 & : & $\begin{array}{l}27358 \\
33582 \\
41004\end{array}$ & $\begin{aligned} 2038 \\
692 \\
692\end{aligned}$ & $\begin{array}{l}38 \\
114 \\
1374 \\
139\end{array}$ & $\begin{array}{r}324 \\
405 \\
41500 \\
41580\end{array}$ & \begin{tabular}{r|r}
5.8 \\
7824 \\
7027
\end{tabular} & 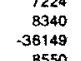 & $\begin{array}{c}3174 \\
1827\end{array}$ & $\begin{array}{c}110 \\
11571\end{array}$ \\
\hline 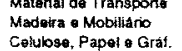 & & $\begin{array}{l}1467 \\
5952 \\
577\end{array}$ & 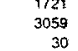 & $:$ & & $\begin{array}{l}0 \\
0 \\
0\end{array}$ & $\begin{array}{r}404 \\
1637 \\
159\end{array}$ & $\begin{array}{l}283 \\
502 \\
5\end{array}$ & $:$ & : & $\begin{array}{r}9985 \\
16029 \\
46957\end{array}$ & $\begin{array}{c}204 \\
150 \\
150\end{array}$ & $\begin{array}{l}590 \\
1101 \\
167\end{array}$ & $\begin{array}{l}20084 \\
9224 \\
29245\end{array}$ & $\begin{array}{l}2727 \\
4155 \\
852\end{array}$ & $\begin{array}{l}8550 \\
29897 \\
15962\end{array}$ & $\begin{array}{c}192 \\
1178 \\
113\end{array}$ & $\begin{array}{l}241 \\
782 \\
62\end{array}$ \\
\hline $\begin{array}{l}\text { ind da Borracha } \\
\text { Ouimica }\end{array}$ & $\begin{array}{l}9 \\
10 \\
11\end{array}$ & $\begin{array}{l}571 \\
479 \\
68\end{array}$ & & $\begin{array}{l}0 \\
0 \\
0\end{array}$ & 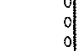 & 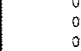 & $\begin{array}{c}159 \\
132 \\
19\end{array}$ & & $\begin{array}{l}0 \\
0 \\
0\end{array}$ & 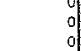 & $\begin{array}{l}10451 \\
10460 \\
5730\end{array}$ & $\begin{array}{r}109 \\
8097 \\
7\end{array}$ & $\begin{array}{l}678 \\
504 \\
8\end{array}$ & $\begin{array}{l}\begin{array}{r}29646 \\
12364 \\
128\end{array} \\
128\end{array}$ & $\begin{array}{l}852 \\
2523 \\
37\end{array}$ & $\begin{array}{r}15692 \\
1722 \\
16993\end{array}$ & $\begin{array}{c}173 \\
128 \\
1\end{array}$ & $\begin{array}{l}\begin{array}{l}62 \\
51 \\
8\end{array} \\
8\end{array}$ \\
\hline 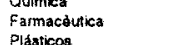 & 12 & & & & & & ${ }_{0}^{19}$ & $0_{0}^{3}$ & 0 & 0 & 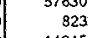 & 0 & 8 & $\frac{126}{7}$ & 4 & $\begin{array}{r}76993 \\
748\end{array}$ & 0 & $g$ \\
\hline $\begin{array}{l}\text { Siticos } \\
\text { itaxul }\end{array}$ & $\begin{array}{l}13 \\
14\end{array}$ & ${ }^{6}$ & & $:$ & 0 & $:$ & ${ }_{3}^{2}$ & $: 0$ & $:$ & : & 38350 & $\begin{array}{c}22 \\
158 \\
158\end{array}$ & $\begin{array}{l}5 \\
2 \\
2\end{array}$ & $\begin{array}{l}123 \\
61\end{array}$ & $\begin{array}{l}27 \\
26\end{array}$ & $\begin{array}{r}1455 \\
38503 \\
3803\end{array}$ & 238 & ; \\
\hline 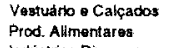 & $\begin{array}{l}15 \\
18\end{array}$ & $\begin{array}{r}0 \\
6793 \\
\end{array}$ & & $:$ & & $\begin{array}{l}0 \\
0\end{array}$ & 1869 & : & $: 0$ & : & $\begin{array}{l}7454 \\
14450\end{array}$ & 242 & $\begin{array}{r}0 \\
246\end{array}$ & $\begin{array}{r}0 \\
3169\end{array}$ & 1326 & $\begin{aligned} 84544 \\
45397\end{aligned}$ & ${ }_{285}^{0}$ & $788^{\circ}$ \\
\hline 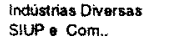 & 78 & 1842 & 659 & $: 0$ & & $\begin{array}{l}0 \\
0\end{array}$ & ${ }^{507} 0$ & $\begin{aligned} 108 \\
0\end{aligned}$ & $:$ & : & $\begin{array}{c}9951 \\
62950\end{array}$ & $\begin{array}{c}940 \\
0\end{array}$ & $\begin{array}{r}284 \\
0\end{array}$ & $\begin{aligned} 6333 \\
0\end{aligned}$ & 1275 & $\begin{array}{l}9499 \\
3437\end{array}$ & $\begin{array}{l}167 \\
0\end{array}$ & $\begin{aligned} 228 \\
0\end{aligned}$ \\
\hline structa CN & 19 & $\begin{array}{r}0 \\
25319\end{array}$ & $\begin{array}{r}0 \\
2955\end{array}$ & $\begin{array}{l}0 \\
0\end{array}$ & of & $\begin{array}{l}0 \\
0 \\
0\end{array}$ & $\begin{array}{r}0 \\
6964\end{array}$ & $\begin{array}{r}0 \\
485\end{array}$ & $\begin{array}{l}0 \\
0\end{array}$ & of & $\begin{array}{l}42232 \\
61629\end{array}$ & 0 & $\begin{array}{r}0 \\
1147\end{array}$ & $\begin{array}{r}0 \\
13769\end{array}$ & $\begin{array}{r}\text { 4210 } \\
40\end{array}$ & $\begin{array}{l}4550868 \\
71177\end{array}$ & 0 & 323 \\
\hline vicoses & $\begin{array}{l}21 \\
N-22\end{array}$ & $\begin{array}{c}2059 \\
520 \\
\end{array}$ & $\begin{array}{l}90 \\
40 \\
\end{array}$ & 0 & a & $\therefore$ & $\begin{array}{l}566 \\
1.43 \\
\end{array}$ & 15 & $\therefore$ & a & $\begin{array}{l}28556 \\
8453\end{array}$ & $\begin{array}{c}115 \\
30 \\
30\end{array}$ & $\begin{array}{r}543 \\
35 \\
\end{array}$ & $\begin{array}{r}706 t \\
4822 \\
\end{array}$ & $\begin{array}{l}2345 \\
162 \\
162 \\
\end{array}$ & $\begin{array}{r}203022 \\
511408 \\
\end{array}$ & $\begin{array}{l}32 \\
16 \\
\end{array}$ & $\begin{array}{r}222 \\
57 \\
\end{array}$ \\
\hline poscundia & $\begin{array}{lll}\text { NE. } 23 & \\
24 & \end{array}$ & ${ }_{33}^{1726}$ & $\begin{array}{l}19997 \\
7\end{array}$ & 0 & & 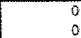 & $\begin{array}{l}4050 \\
9\end{array}$ & 328 & 0 & 8 & $\begin{array}{r}68 \\
190\end{array}$ & $\begin{array}{l}314894 \\
312596 \\
2596\end{array}$ & $\begin{array}{l}2419 \\
2118\end{array}$ & 200989 & | 1378 & $\begin{array}{r}1697 \\
17\end{array}$ & $\begin{array}{l}35922 \\
12520\end{array}$ & \\
\hline $\begin{array}{l}\text { orais năo Motalicon } \\
\text { aturgia }\end{array}$ & ${ }_{28}^{58}$ & 362 & 96 & 0 & & $:$ & $\begin{array}{r}3^{2} \\
100^{2}-1\end{array}$ & 16 & $:$ & d & 5.46 & $\begin{array}{l}179596 \\
92995 \\
110879\end{array}$ & $\begin{array}{l}58 \\
562\end{array}$ & $\begin{array}{l}3008 \\
2009 \\
2003\end{array}$ & 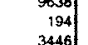 & $\begin{array}{r}11 \\
683 \\
63\end{array}$ & $\begin{array}{l}2504 \\
25434\end{array}$ & 43 \\
\hline 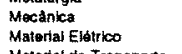 & 0 & $\begin{array}{r}31 \\
1757 \\
157\end{array}$ & N & $:$ & 0 & $:$ & $\begin{array}{c}9 \\
483 \\
483\end{array}$ & 213 & $: 0$ & : & $\begin{array}{l}1176 \\
5450\end{array}$ & $\begin{array}{l}73754 \\
25321\end{array}$ & $\begin{array}{l}35 \\
275 \\
275\end{array}$ & 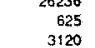 & $\begin{array}{l}125 \\
7004\end{array}$ & $\begin{array}{l}6657 \\
6710 \\
1410\end{array}$ & ton & 150 \\
\hline 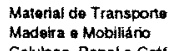 & 30 & 007 & ${ }_{358}$ & 0 & & $\begin{array}{c}0 \\
0\end{array}$ & 0 & & $: 0$ & of & $\begin{array}{l}2037 \\
512\end{array}$ & $\begin{array}{l}4050 \\
20541\end{array}$ & ${ }_{68}^{68}$ & $\begin{array}{r}2375 \\
7\end{array}$ & $\begin{array}{r}344 \\
18\end{array}$ & $\begin{array}{l}9197 \\
145\end{array}$ & $\begin{array}{l}2.1712 \\
17207\end{array}$ & 50 \\
\hline 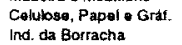 & 31 & 8 & & : & & 0 & & & : & 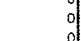 & $\begin{array}{l}466 \\
453\end{array}$ & $\begin{array}{l}27267 \\
4828\end{array}$ & 14 & $\begin{array}{r}302 \\
120\end{array}$ & $\begin{array}{r}69 \\
528\end{array}$ & ${ }_{14}^{14}$ & $\begin{array}{l}3224 \\
3768\end{array}$ & \\
\hline $\begin{array}{l}\text { mikika } \\
\text { macosuluca }\end{array}$ & $\begin{array}{l}23 \\
34 \\
34\end{array}$ & $\begin{array}{l}1945 \\
681 \\
681\end{array}$ & 16 & $\begin{array}{c}0 \\
0 \\
0\end{array}$ & of & $\vdots$ & $\begin{array}{l}408 \\
187 \\
187 \\
\text {. }\end{array}$ & 3 & $\begin{array}{c}0 \\
0 \\
0\end{array}$ & : & $\begin{array}{l}4412 \\
4532\end{array}$ & $\begin{aligned} 375126 \\
2661\end{aligned}$ & $\begin{array}{l}8014 \\
20\end{array}$ & $\begin{array}{l}100463 \\
208\end{array}$ & $\begin{array}{l}36624 \\
64]\end{array}$ & $\begin{array}{l}643 \\
1547\end{array}$ & $\begin{array}{l}91492 \\
12384\end{array}$ & $\begin{array}{r}158 \\
72\end{array}$ \\
\hline $\begin{array}{l}\text { sicos } \\
\text { Troxil }\end{array}$ & $\begin{array}{l}35 \\
36\end{array}$ & $\begin{array}{l}308 \\
3748 \\
7748\end{array}$ & & $:$ & & 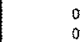 & $\begin{array}{r}85 \\
481 \\
481\end{array}$ & 0 & $:$ & : & $\begin{array}{l}1628 \\
670\end{array}$ & $\begin{array}{l}21252 \\
71787\end{array}$ & $\begin{array}{r}258 \\
1484\end{array}$ & $\begin{array}{l}3623 \\
36219 \\
3\end{array}$ & $\begin{aligned} 12222 \\
13104\end{aligned}$ & $\begin{array}{l}151 \\
548\end{array}$ & $\begin{array}{l}3352 \\
33894 \\
3094\end{array}$ & $\begin{array}{l}39 \\
85\end{array}$ \\
\hline 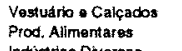 & $\begin{array}{l}37 \\
38\end{array}$ & $\begin{array}{r}1590 \\
11310\end{array}$ & & $:$ & of & $:$ & $\begin{array}{r}437 \\
3111\end{array}$ & 0 & $:$ & : & $\begin{array}{c}73 \\
701\end{array}$ & $\begin{array}{l}17768 \\
17258\end{array}$ & $\begin{array}{r}36 \\
1083\end{array}$ & $\begin{array}{l}909 \\
1957\end{array}$ & $\begin{array}{c}494 \\
7607\end{array}$ & $\begin{array}{l}10592 \\
5488 \\
5489\end{array}$ & $\begin{array}{l}104644 \\
205594\end{array}$ & $\begin{array}{r}168 \\
1195\end{array}$ \\
\hline 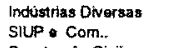 & $\begin{array}{r}39 \\
40\end{array}$ & 252 & & $:$ & : & $:$ & $\stackrel{69}{9}$ & ${ }_{0}^{8}$ & $:$ & of & $\begin{array}{l}10 \\
0\end{array}$ & $\begin{aligned} 73998 \\
216778\end{aligned}$ & 11 & ${ }_{1}^{244}$ & & $\begin{array}{r}125 \\
0\end{array}$ & $\begin{array}{l}-1785 \\
53487\end{array}$ & \\
\hline 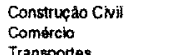 & $\begin{array}{l}41 \\
42\end{array}$ & $\begin{array}{r}0 \\
114715\end{array}$ & 13358 & $:$ & $:$ & $\begin{array}{l}0 \\
0\end{array}$ & $\begin{array}{l}0 \quad 31552 \\
0\end{array}$ & $\begin{array}{r}0 \\
2193\end{array}$ & $:$ & : & $\begin{array}{r}0^{\circ} \\
944^{\circ}\end{array}$ & $\begin{array}{l}111920 \\
265040\end{array}$ & 6189 & 78083 & 23256] & $\begin{array}{r}0 \\
899\end{array}$ & $\begin{array}{l}\begin{array}{r}1323734 \\
23427 \\
23427\end{array} \\
.\end{array}$ & 12788 \\
\hline 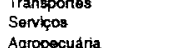 & $=43$ & $\begin{array}{l}3617 \\
67784 \\
6\end{array}$ & & & a & 0 & 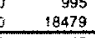 & & $\stackrel{0}{a}$ & 9 & 1.97 & $\begin{array}{r}\begin{array}{r}386553 \\
310544 \\
\end{array} \\
\end{array}$ & $\begin{array}{r}677 \\
1.540 \\
\end{array}$ & 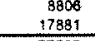 & $\begin{array}{l}29225 \\
{ }_{52285}\end{array}$ & $3630^{\circ}$ & $\begin{array}{l}112714 \\
1557692 \\
\end{array}$ & $\begin{array}{l}3090 \\
7098 \\
\end{array}$ \\
\hline pactána & $\begin{array}{c}0.45 \\
46\end{array}$ & 41676 & 4389 & & of & 0 & 43 & 0 & 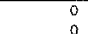 & d & $\begin{array}{l}34 \\
469 \\
469\end{array}$ & & 1389 & 777563 & 182 & 547 & $\begin{array}{ll}2205 \\
2\end{array}$ & (1597\% \\
\hline 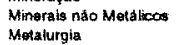 & $\begin{array}{l}{ }_{48}^{47} \\
48\end{array}$ & $\begin{array}{l}252 \\
127 \\
127\end{array}$ & 4 & & & $:$ & $\begin{array}{l}118 \\
170 \\
170\end{array}$ & & $:$ & 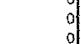 & $\begin{array}{l}2310 \\
2310\end{array}$ & $\begin{array}{c}2008 \\
208 \\
228\end{array}$ & $\begin{array}{l}45372 \\
24301 \\
2530\end{array}$ & $\begin{array}{l}10907 \\
3197 \\
131\end{array}$ & $\begin{array}{l}2302 \\
2472 \\
372\end{array}$ & $\begin{array}{l}14 \\
27\end{array}$ & & 79 \\
\hline $\begin{array}{l}\text { cantica } \\
\text { carial Elatitico }\end{array}$ & 49 & $\begin{array}{l}17 \\
35\end{array}$ & & & & $\begin{array}{l}0 \\
0\end{array}$ & ${ }_{263}^{1}$ & $\begin{array}{l}44 \\
142\end{array}$ & $:$ & & $\begin{array}{r}19 \\
202\end{array}$ & $\begin{array}{l}67 \\
48\end{array}$ & $\begin{array}{l}2627 \\
2632\end{array}$ & $\begin{array}{l}26 \\
26\end{array}$ & $\begin{array}{l}150 \\
218\end{array}$ & $\begin{array}{l}20 \\
19\end{array}$ & $\begin{array}{r}18 \\
191\end{array}$ & 42 \\
\hline 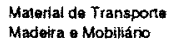 & $\begin{array}{l}51 \\
52\end{array}$ & 153 & 1147 & $:$ & & $\vdots$ & $\frac{9}{7}$ & $\stackrel{6}{i}$ & $:$ & 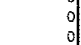 & $\begin{array}{r}24 \\
34 \\
66\end{array}$ & $\frac{33}{11}$ & 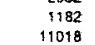 & $\begin{array}{r}0 \\
2783\end{array}$ & $\begin{array}{l}42 \\
15\end{array}$ & $\begin{array}{r}9 \\
168\end{array}$ & $\begin{array}{c}31 \\
802\end{array}$ & $\begin{array}{l}2774 \\
11778\end{array}$ \\
\hline 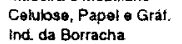 & $\begin{array}{l}53 \\
54\end{array}$ & 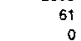 & & $:$ & & $\begin{array}{c}0 \\
0 \\
0\end{array}$ & ${ }_{3}^{139}$ & ${ }_{0}^{2}$ & $\begin{array}{c}0 \\
0\end{array}$ & of & $\begin{array}{l}66 \\
25\end{array}$ & $\begin{array}{l}176 \\
118 \\
118\end{array}$ & $\begin{array}{c}15138 \\
3028 \\
3028\end{array}$ & $\begin{array}{l}32 \\
0\end{array}$ & $\begin{array}{l}667 \\
551\end{array}$ & 138 & 143 & 5107 \\
\hline 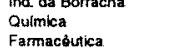 & $\begin{array}{l}54 \\
55 \\
55\end{array}$ & 79 & 8 & : & 0 & 0 & $661^{3}$ & 0 & 等 & 9 & $\begin{array}{l}128 \\
1489 \\
170\end{array}$ & $\begin{array}{l}4708 \\
4708 \\
-105\end{array}$ & $\begin{array}{l}3028 \\
103696 \\
10369\end{array}$ & $173^{3}$ & $\begin{array}{c}\text { 701 } \\
7089 \\
\end{array}$ & $\begin{array}{c}165 \\
165\end{array}$ & 363 & $\begin{array}{l}12605 \\
10600 \\
1.978\end{array}$ \\
\hline $\begin{array}{l}\text { Tacos } \\
\text { Toxxili }\end{array}$ & $\begin{array}{l}56 \\
57 \\
58\end{array}$ & 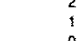 & & $: 0$ & 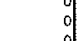 & : & 2 & $\therefore$ & 0 & a. & 年 & $\begin{array}{l}351 \\
84 \\
708\end{array}$ & $\begin{array}{l}2476 \\
2720\end{array}$ & 1116 & $\begin{array}{l}308 \\
189\end{array}$ & 0 & $\begin{array}{l}12 \\
2\end{array}$ & $\begin{array}{l}12788 \\
1818 \\
181\end{array}$ \\
\hline 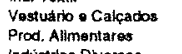 & $\begin{array}{l}59 \\
60\end{array}$ & $\begin{array}{r}3839 \\
38234\end{array}$ & & : & 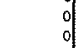 & $\begin{array}{l}0 \\
0\end{array}$ & $\begin{aligned} 104 \\
8 \\
398\end{aligned}$ & : & $:$ & 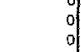 & $\begin{array}{r}4 \\
235\end{array}$ & $\begin{array}{r}48 \\
4582 \\
152\end{array}$ & $\begin{array}{r}1350 \\
1425 \\
46406\end{array}$ & $\begin{array}{r}439 \\
14633 \\
1463\end{array}$ & $\begin{array}{c}5 \\
573 \\
573\end{array}$ & 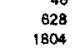 & 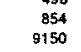 & $\begin{array}{l}17986 \\
70994\end{array}$ \\
\hline 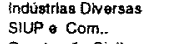 & $\begin{array}{l}61 \\
62\end{array}$ & $\begin{array}{r}3 \\
4189 \\
\end{array}$ & 0 & $: 0$ & : & $:$ & $\begin{array}{c}12 \\
233\end{array}$ & $\stackrel{2}{1}$ & $:$ & of & $805^{4}$ & $\begin{array}{c}16 \\
3\end{array}$ & $\begin{array}{r}759 \\
42361\end{array}$ & $\begin{array}{r}6 \\
11865\end{array}$ & $\begin{array}{r}67 \\
118\end{array}$ & 280 & $\begin{array}{l}6 \\
0\end{array}$ & 5313 \\
\hline 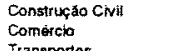 & ${ }_{64}^{63}$ & 23833 & 2829 & & of & 0 & 1972 & $\begin{array}{l}16705 \\
18 \\
18\end{array}$ & $: 0$ & & 202 & ${ }_{293}^{\prime}$ & $\begin{array}{l}48007 \\
91973\end{array}$ & $\begin{array}{r}19085 \\
0\end{array}$ & 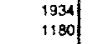 & $\begin{array}{l}0 \\
137\end{array}$ & $\begin{array}{c}0 \\
0\end{array}$ & $\begin{array}{l}350832 \\
555230\end{array}$ \\
\hline masporas & 65 & $\begin{array}{c}3666 \\
16431 \\
1631\end{array}$ & $\begin{array}{r}164 \\
1098 \\
\end{array}$ & : & o & $\begin{array}{c}0 \\
0 \\
0\end{array}$ & $\begin{array}{l}404 \\
93587\end{array}$ & 392 & 0 & 0 & $\begin{array}{r}13 \\
1296\end{array}$ & $\begin{array}{l}346 \\
3412 \\
412\end{array}$ & $\begin{array}{l}559982 \\
297257\end{array}$ & $\begin{array}{c}9131 \\
99093 \\
19093\end{array}$ & $\begin{aligned} 2744 \\
28040\end{aligned}$ & $\begin{array}{c}12 \\
2342\end{array}$ & $\begin{array}{l}241 \\
769\end{array}$ & 43481 \\
\hline 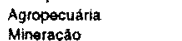 & SE-67" & & 48034 & 年 & 21009 & & 1094 & & & & 264 & & & & & & $\frac{3279}{327}$ & \\
\hline 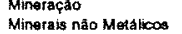 & ${ }^{68}$ & 5 & & & 129581 & 0 & 454 & 39 & 0 & d & 5797 & 1393 & 7473 & 270557 & 25099] & 47 & 361 & 27 \\
\hline sola & 70 & $\begin{array}{l}24790 \\
59790\end{array}$ & 20939 & $\begin{array}{l}.12492 \\
.12497\end{array}$ & $\begin{array}{c}13775 \\
296218\end{array}$ & 0 & $\begin{array}{l}1370 \\
9828\end{array}$ & ${ }_{1452}^{2}$ & 0 & & $\begin{array}{l}572283 \\
27283\end{array}$ & $\begin{array}{l}4.7274 \\
39995\end{array}$ & $\begin{array}{l}323 \\
3228 \\
\end{array}$ & $\begin{array}{l}486633 \\
1892938\end{array}$ & $\begin{array}{l}196946 \\
159225\end{array}$ & $\begin{array}{l}334 \\
3186\end{array}$ & $\begin{array}{l}3200 \\
1800\end{array}$ & 193 \\
\hline & $\begin{array}{l}71 \\
72\end{array}$ & $\begin{aligned} 235533 \\
213539\end{aligned}$ & $\begin{array}{l}3239197 \\
236194\end{array}$ & $\begin{array}{l}.99043 \\
.40135\end{array}$ & $\begin{array}{l}578289 \\
74458\end{array}$ & $\begin{array}{l}0 \\
0 \\
0\end{array}$ & $\begin{array}{r}1880 \\
32510\end{array}$ & 17740 & 要 & & $\begin{array}{r}54 \\
462\end{array}$ & 35 & $\begin{array}{l}12874 \\
1.2750\end{array}$ & 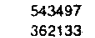 & 35976] & $\begin{array}{l}9372 \\
{ }_{3515}\end{array}$ & 30132 & 01 \\
\hline ide trans on onts & 73 & $\begin{array}{l}237566 \\
31766\end{array}$ & 394789 & - 181753 & 188609 & & $\begin{array}{l}12665 \\
1265 \\
\end{array}$ & $70 \div 0$ & & & $\begin{array}{l}8010 \\
14479\end{array}$ & 10508 & 10665 & 6.5356: & 19 & 17351 & 年 & $\begin{array}{l}780787 \\
28187\end{array}$ \\
\hline 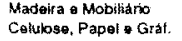 & $\begin{array}{l}74 \\
75\end{array}$ & $\begin{array}{r}98574 \\
100980\end{array}$ & 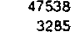 & -4.394 & $\begin{array}{r}6775 \\
39227\end{array}$ & $\begin{array}{l}0 \\
0\end{array}$ & $\begin{array}{r}151 \\
3739\end{array}$ & ${ }_{71}^{27}$ & $\begin{array}{l}0 \\
0\end{array}$ & & $\begin{array}{l}1300 \\
3567\end{array}$ & $\begin{array}{l}406 \\
9565\end{array}$ & $\begin{array}{l}3883 \\
.1512 \\
15112\end{array}$ & $\begin{array}{l}122321 \\
599668\end{array}$ & $\begin{array}{r}548 \\
\text { 21987 }\end{array}$ & $\begin{array}{l}2005 \\
5994\end{array}$ & $\begin{array}{l}13803 \\
62299 \\
629\end{array}$ & 229 \\
\hline $\begin{array}{l}\text { da Borracha } \\
\text { inca }\end{array}$ & 76 & $\begin{array}{r}1512 \\
20591 \\
\end{array}$ & $\begin{array}{r}143 \\
3076\end{array}$ & 5705 & 12187 & 0 & 138 & 150 & 0 & of & 45153 & $\begin{array}{l}12076 \\
123421 \\
.3421\end{array}$ & $\begin{array}{l}5282 \\
77473 \\
7\end{array}$ & $\begin{array}{l}224879 \\
220856\end{array}$ & 244667] & 18 & (1020 & (1) \\
\hline ética & 78 & & 4376 & $\begin{array}{l}\text {. } 27807 \\
.2819\end{array}$ & $\begin{array}{l}1082979 \\
7996\end{array}$ & $\begin{array}{l}0 \\
0\end{array}$ & $\begin{array}{l}141415 \\
62506\end{array}$ & & : & & 45123 & 133. & 667 & $\begin{array}{l}2098865 \\
58912 \\
5812\end{array}$ & $179904]$ & $\begin{array}{l}4933 \\
8182\end{array}$ & 12334 & $\begin{array}{l}9881 \\
14138 \\
\end{array}$ \\
\hline & 79 & & 568 & .8735 & 4 & 0 & 1597 & 16 & 0 & & & 166 & $1: 1300$ & 2823 & & 8 & 2496 & (194. \\
\hline cad & 80 & & 200 & $\begin{aligned} 8051 \\
.32856 \\
\end{aligned}$ & $\begin{array}{l}354 \\
44\end{array}$ & $:$ & $\begin{aligned} 2808 \\
109\end{aligned}$ & $\begin{array}{l}7 \\
5 \\
\end{array}$ & $:$ & & ${ }_{7}^{3}$ & & & 555 & & & & 46 \\
\hline 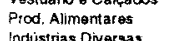 & 82 & & 1839 & & 190880 & 0 & 19282 & 38 & : & & 4162 & & $\begin{array}{l}7049 \\
7089 \\
\end{array}$ & 3449 & 43 & 26745 & 306 & 6.63 \\
\hline Diversas & $\begin{array}{l}83 \\
84\end{array}$ & $\begin{array}{r}61380 \\
339400\end{array}$ & $\begin{array}{l}12506 \\
350\end{array}$ & $\begin{array}{l}.13008 \\
25958\end{array}$ & $\begin{array}{l}9598 \\
3762\end{array}$ & $: 0$ & $\begin{array}{r}5877 \\
310\end{array}$ & $\begin{array}{l}586 \\
16\end{array}$ & $\begin{array}{c}0 \\
0\end{array}$ & & 14996 & 638 & $\begin{array}{l}5237 \\
118\end{array}$ & 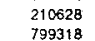 & of & $\begin{array}{l}663 \\
5836\end{array}$ & 5532 & . \\
\hline $\begin{array}{l}\text { strucajo } \mathrm{CN} \text {. } \\
\text { nercio }\end{array}$ & 85 & 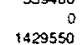 & $\begin{array}{l}1643042 \\
15497 \\
1547\end{array}$ & $\begin{aligned}-1153919 \\
-15376\end{aligned}$ & 278355 & 0 & 100 & $\begin{array}{l}66258 \\
629\end{array}$ & 0 & o & 3728 & $\begin{array}{r}12 \\
12 \\
8705\end{array}$ & $\begin{array}{r}10 \\
365\end{array}$ & $\begin{array}{l}207432 \\
207323\end{array}$ & $\begin{array}{l}14257 \\
107997\end{array}$ & $\begin{array}{ll}0 \\
0 \\
268\end{array}$ & 5723 & 50 \\
\hline$\omega_{0}$ & $\begin{array}{l}80 \\
87 \\
8-8\end{array}$ & 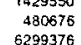 & 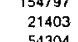 & 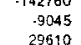 & 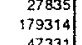 & 0 & 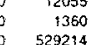 & $\begin{aligned} 129 \\
16 \\
2715\end{aligned}$ & 0 & & 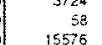 & $\begin{array}{l}5843 \\
582832 \\
10282\end{array}$ & 年 465 & 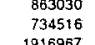 & 年 586 & $\begin{array}{l}2688 \\
900 \\
290\end{array}$ & 年6699 & $\begin{array}{l}2489 \\
57\end{array}$ \\
\hline & ${ }_{5-89}$ & $g$ & 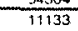 & 610 & & & 19762 & 7057 & 1666 & & & & & & & & & 67 \\
\hline so Meaticos & $\infty$ & 4 & & 0 & & 0 & 869 & 86 & 56 & & ${ }_{445}$ & 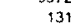 & $\begin{aligned} 5419 \\
919\end{aligned}$ & 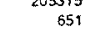 & & 17) & & 34 \\
\hline o Matheos & ${ }_{92}^{91}$ & & & & & $\begin{array}{l}0 \\
0\end{array}$ & $\begin{array}{l}9328 \\
7131\end{array}$ & $\begin{array}{r}117 \\
2088\end{array}$ & $\begin{array}{l}.1534 \\
-.3426 \\
-3426\end{array}$ & & 1166 & & & $\begin{array}{l}1485 \\
13\end{array}$ & & $\begin{array}{c}107 \\
274\end{array}$ & & \\
\hline anica & 93 & 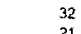 & & 0 & & 0 & $\begin{array}{l}14310 \\
45520\end{array}$ & $\begin{array}{l}90501 \\
25692\end{array}$ & 年. 1674 & 3041 & ist & 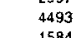 & $\begin{array}{l}4168 \\
4168\end{array}$ & 23 & 136 & $\begin{array}{l}3250 \\
591\end{array}$ & $\begin{array}{l}3657 \\
5056\end{array}$ & \\
\hline 然 & 95 & & 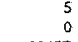 & : & & 0 & $\begin{array}{l}45220 \\
22255\end{array}$ & $\begin{array}{l}25642 \\
14607\end{array}$ & 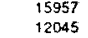 & 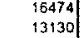 & 1012 & 974 & $\begin{aligned} 21334 \\
884\end{aligned}$ & & 288938 & $\begin{array}{l}591 \\
844\end{array}$ & & 77 \\
\hline 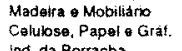 & 96 & $\begin{array}{r}41715 \\
28\end{array}$ & 20457 & & & & $\begin{array}{l}{ }_{232635} 2162 \\
202\end{array}$ & $\begin{array}{l}14436 \\
427\end{array}$ & $\begin{array}{l}-21447 \\
2404 \\
2404\end{array}$ & $\begin{array}{l}11448 \\
11331 \\
11331\end{array}$ & $\begin{array}{l}1203 \\
901\end{array}$ & $\begin{array}{l}364 \\
2435 \\
243\end{array}$ & $\begin{array}{l}3134 \\
3301 \\
330\end{array}$ & $\begin{array}{l}42883 \\
21\end{array}$ & 200709 & $\begin{array}{l}3122 \\
1244\end{array}$ & $\begin{array}{l}14613 \\
1393 \\
1393\end{array}$ & $\begin{array}{l}799 \\
03\end{array}$ \\
\hline Buratha & 98 & & & 0 & & & 689 & 177 & 199 & 3214 & 321 & 1420 & 795 & 5 & 30673 & 17 & 149 & (39 \\
\hline & 100 & 25 & 15 & $:$ & & & $\begin{array}{l}26574 \\
12820\end{array}$ & $\begin{array}{c}974 \\
17\end{array}$ & $\begin{array}{l}5910 \\
.549 \\
.549\end{array}$ & $\begin{array}{r}18995 \\
4255 \\
4\end{array}$ & 74.8 & 220 & 997 & $\begin{array}{l}217 \\
115 \\
15\end{array}$ & $\begin{array}{l}38512 \\
285\end{array}$ & $\begin{array}{c}530 \\
302 \\
302\end{array}$ & $\begin{array}{l}1694 \\
1320\end{array}$ & 907 \\
\hline 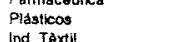 & 109 & 144 & 29 & 0 & & 0 & $\begin{array}{l}82897 \\
67990\end{array}$ & 398 & $\begin{array}{l}-5962 \\
-4962 \\
-496\end{array}$ & 年557 & 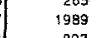 & $\begin{array}{l}546 \\
3318 \\
3318\end{array}$ & 174 & $\begin{array}{r}152 \\
152 \\
2\end{array}$ & (5)92939 & 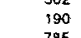 & 年 & 8 \\
\hline 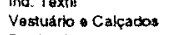 & 102 & $\begin{array}{l}87947 \\
87917\end{array}$ & $\begin{array}{l}5 \\
4 \\
4\end{array}$ & $: 0$ & & & $\begin{array}{ll}0 \\
0 \\
0 & 1899504 \\
18950\end{array}$ & $\begin{array}{l}393 \\
397 \\
397\end{array}$ & $\begin{array}{l}-8207 \\
12108 \\
12108\end{array}$ & $\begin{array}{l}77348, \\
490001\end{array}$ & 803 & $\begin{array}{l}72700 \\
1054\end{array}$ & $\begin{array}{r}1675 \\
848 \\
848\end{array}$ & $\begin{array}{r}76 \\
9364\end{array}$ & $\begin{array}{c}19000000 \\
59601\end{array}$ & $\begin{array}{r}875 \\
17282\end{array}$ & $\begin{array}{l}75877 \\
23377\end{array}$ & $\begin{array}{l}5858 \\
578\end{array}$ \\
\hline 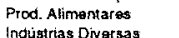 & 104 & 322412 & 76 & 0 & & & 288878 & $\begin{array}{r}520 \\
.1263\end{array}$ & $\begin{array}{r}.2309 \\
3303\end{array}$ & 129048 & $\begin{array}{r}2675 \\
270\end{array}$ & 16850 & $\begin{array}{l}2716 \\
2716\end{array}$ & $\begin{array}{r}163516 \\
51516\end{array}$ & $\begin{array}{l}3486066 \\
3\end{array}$ & 14426 & $\begin{array}{l}69605 \\
69605\end{array}$ & 4923 \\
\hline $\begin{array}{l}\text { tas Dorrat } \\
\text { Comm. }\end{array}$ & $\begin{array}{l}105 \\
106\end{array}$ & $\begin{array}{r}29 \\
22249\end{array}$ & 0 & 年 & & & $\begin{array}{ll}0 & 10082 \\
0 & 12831\end{array}$ & $\begin{array}{r}1263 \\
454\end{array}$ & $\begin{array}{r}-23033 \\
-23615\end{array}$ & $\left.\begin{array}{l}9951 \\
2760\end{array}\right]$ & $\begin{array}{r}1098 \\
4487\end{array}$ & $\begin{array}{l}789 \\
229 \\
229\end{array}$ & $\begin{array}{l}778 \\
184\end{array}$ & 37751 & $\begin{array}{c}2099289 \\
206651\end{array}$ & $\begin{array}{r}93 \\
2601\end{array}$ & $\begin{array}{l}683 \\
302\end{array}$ & $\begin{array}{l}469 \\
208\end{array}$ \\
\hline cato c crif & 108 & $\begin{array}{r}40693 \\
70691\end{array}$ & $\begin{array}{r}278 \\
8454\end{array}$ & 0 & & & $\begin{array}{l}0231 \\
0\end{array}$ & $\begin{array}{l}6427272 \\
222925\end{array}$ & $\begin{array}{l}-1775274 \\
1115200\end{array}$ & $\begin{array}{r}14351 \\
1435\end{array}$ & $\begin{array}{r}5 \\
1745\end{array}$ & 3993 & $\begin{array}{r}0 \\
1619\end{array}$ & $\begin{array}{r}679 \\
47873\end{array}$ & 372386 & 1130 & 2174 & 840 \\
\hline 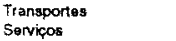 & $\begin{array}{l}109 \\
\text { s. } 110 .\end{array}$ & $\begin{array}{l}700 \\
817\end{array}$ & 191 & 0 & & $811700^{\circ}$ & $\begin{array}{r}122082 \\
1314441\end{array}$ & $\begin{array}{r}3658 \\
196707\end{array}$ & $\begin{array}{r}-8624 \\
-98924 \\
99925\end{array}$ & 80221 & 115 & $\begin{array}{l}2167 \\
2167\end{array}$ & 84 & $\begin{array}{r}3343 \\
3368\end{array}$ & $\begin{array}{l}2405022 \\
37768\end{array}$ & $\begin{array}{r}134 \\
9699\end{array}$ & $\begin{array}{l}2350 \\
7555\end{array}$ & 80 \\
\hline 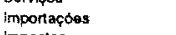 & 111 & & 243197 & & & & & 39925 & $\frac{1758}{.776}$ & 1383 & $\frac{1032}{68662}$ & & 68820 & 11796024 & & & 1000 & $\frac{5128}{228}$ \\
\hline tos & 112 & 11423391 & 361761 & . 436466 & 54943 & 10001 & $\begin{array}{l}31.4490 \\
\end{array}$ & 59389 & -13548 & 29974 & 75984 & 173 & 155472 & 1900869 & 1 & 1.138268 & 281588 & 135986 \\
\hline & 114 & & $:$ & & & 825701 & 0 & 0 & & & $\begin{array}{l}5659590 \\
10238888\end{array}$ & 2822765 & 1038875 & $\begin{array}{l}864555449 \\
86296997\end{array}$ & 28465966 & & & \\
\hline & 1115 & & & & & & & & & & $\begin{array}{r}1589859 \\
324069\end{array}$ & $\begin{array}{l}4909441 \\
81181\end{array}$ & 2 & & 131 & & & \\
\hline 1000 & 117 & & 0 & & & & & 0 & & & $\begin{array}{l}3.24606 \\
15227\end{array}$ & $\begin{array}{l}.90025 \\
-10025\end{array}$ & $\begin{array}{l}.12725 \\
12476\end{array}$ & $\begin{array}{l}.3832303 \\
.312714\end{array}$ & .573 & & & \\
\hline & 11 & & & & & & & & & & & & & & & & & \\
\hline Soma thr & 120 & & 0 & 0 & & & & $a$ & & & 28682 & $\begin{array}{r}2325926 \\
\end{array}$ & $\begin{array}{r}24003 \\
200367\end{array}$ & $\begin{array}{r}425018 \\
43205\end{array}$ & 18 & & & \\
\hline 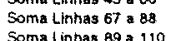 & 12 & & & & & & & & & & $\begin{array}{r}20452 \\
20552 \\
40582\end{array}$ & $\begin{array}{l}12501 \\
42506\end{array}$ & 2387006 & 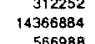 & thent & & & \\
\hline (T) & 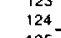 & & & & & & & & & & | & $\begin{array}{r}209993936 \\
0.09936\end{array}$ & 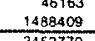 & 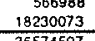 & 2,774 & & & \\
\hline
\end{tabular}


lad da Borracha

Oufrmica

Farmacílutica

Plásticos

Vestuario Calçacos

Prod. Alimertaras

indürtias Dversas

Construçáo CiN

Comircto

Transportes

Serviças

Agropecuária

Mineraçás

Minerais

Mertalurgia

Material Elétrico

Material de Iransporte

Celulase, Papeita Gra

Ind. da Borracha

Ouirnica

Farmaceutica

Prasicos

ind. Toxtil

Vestuatio 9 Calçacos

Prod. Alimentares

StuP Com.

Construça Civil

Comercio

Transportes

Senviço

Agropecuárí

Mineraçăo

Minerais naturgia

Mecánica

Material Elétrico

Material de Iransports

Calubse. Papel $\mathrm{G}$

ind. da Bortacha

Oulmica

Farmacâuica

Plásticos

Ind. Táxtil

Prod. Alimemar es

Indústrias Diversas
SUP * Com..

StUP Com.

Combricio

Transportes

Serviços

Agropecuánia
Minaraçáa

Minerąis náo Metálicos

Metalurgia

Mecanica

Materias Elétrico

Malerial de Iransporte

Madira o Mobiliaric

Collutose, Papal o Gra

Ind. da Borracha

Quimica

Plásticos

ind Téxil

Vestuario - Calçacos

rod. Alimentaras

Indústrias DNers
SIUP B Com.

SIUP Com..

Comercicio

Comirex

Sarviços

Agropecuaria

Mineraçào

Minerals năo Meralicos

Motalurgia

Mecánica

Material Elétrico

Material de Transponte

Madeira o Mobiliário

Ind. da Borrachs

Quimica

Farmacelutic

Iasteos

Vestuatio Caicados

Prod. Alimentares

Indüstrias Divorsas

SluP a Com..

Construc aै०

Comercio

Servicos

mpontaços

!mpostos

Rerrineraçdes

V.A. Gusto do Fatores

impostos s/Ainidads

$\checkmark$ A. Preco Basico

Soma Linhas 1 a

Soma Linhas 1 a 22
Soma Linhas 23 : 44

Soma Linhas 45 a 56

Soma Linhas 67 a 88

Soma Linhas 89 a 110

Soms Linhas 1 a 112

\begin{tabular}{rrr|rrr|}
0 & SE-144 & S.145 & 146 & 147 & 148 \\
\hline 22600 & 5924 & 151702 & 121834 & 273536
\end{tabular}

\begin{tabular}{|c|c|c|c|c|c|}
\hline 2 & 3 & & 88386 & 30344 & 118729 \\
\hline 3 & 44 & 12 & 25573 & 5505 & 31078 \\
\hline 4 & 186 & 47 & 28782 & $\gamma_{482}$ & 36264 \\
\hline 5 & 123 & 30 & 36095 & 11678 & 47774 \\
\hline 6 & 155239 & 33073 & 92565 & 155568 & 258133 \\
\hline 7 & 3189 & 636 & 34185 & 12859 & 47044 \\
\hline 8 & 9014 & 2139 & 30537 & 42926 & 73463 \\
\hline 9 & 607 & 164 & B772 & 15908 & $256 \mathrm{B0}$ \\
\hline 10 & 482 & 1.32 & 26888 & 2515 & 29402 \\
\hline 14 & 85 & 21 & 57807 & $i 7108$ & 74915 \\
\hline 12 & 1 & 0 & 835 & 7749 & 8584 \\
\hline 13 & 7 & 2 & $\$ 5122$ & 1465 & 16588 \\
\hline 14 & 11 & 3 & 38597 & 38754 & 77351 \\
\hline 15 & 0 & 0 & 764 & 8464 & 9228 \\
\hline 16 & 6798 & 1869 & 19434 & 55067 & 74501 \\
\hline 17 & 2501 & 815 & 18783 & 13002 & 31785 \\
\hline 18 & 0 & & 62950 & 34137 & 97087 \\
\hline 19 & 0 & & 42232 & d55086 & 497318 \\
\hline 20 & 28274 & 7449 & 80755 & 109723 & 190479 \\
\hline 21 & 2149 & 581 & 38629 & 23285 & ô1915 \\
\hline 1.22 & 561 & & Q & 512192 & 6828 \\
\hline
\end{tabular}

\begin{tabular}{|c|c|c|c|}
\hline 561 & $\neq 50$ & 84861 & $\begin{array}{r}512192 \\
\end{array}$ \\
\hline 16723 & 4378 & 352157 & d15545 \\
\hline 40 & 10 & 195270 & .25050 \\
\hline
\end{tabular}

\begin{tabular}{rrr|rr|r}
24 & 40 & 10 & 195270 & .25050 & 170220 \\
25 & 8 & 2 & 95279 & 2580 & 97959 \\
26 & 458 & 115 & 146469 & 42642 & 189112 \\
\hline & 45 & 10 & 3494 & 3298 & 6920
\end{tabular}

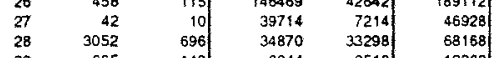

\begin{tabular}{rrr|rr|r|}
29 & 655 & 143 & 8844 & 3518 & 68168 \\
30 & 10 & 2 & 22053 & 21548 & 4362 \\
\hline & 10 & 3 & 4418 & 3951 & 47698
\end{tabular}

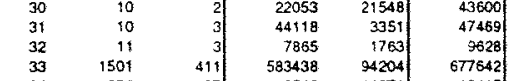

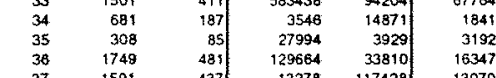

\begin{tabular}{|rrr|rr|r|}
\hline 37 & 1591 & 437 & 129684 & 33810 & 163474 \\
38 & 11312 & 3111 & 93278 & 117428 & 130706 \\
\hline 305 & 316355 & 409540 \\
\hline & 304 & 78 & 7788 & &
\end{tabular}

\begin{tabular}{rrr|rr|r}
40 & 304 & 78 & 7708 & -1229 & 6479 \\
41 & 0 & 0 & 216779 & 53490 & 270270 \\
111920 & 1323734 & 1435654
\end{tabular}

\begin{tabular}{|rrr|r|r|r|}
\hline 43 & 3775 & 33745 & 373511 & 409832 & 783343 \\
\hline & 96261 & 117900 & 214100 \\
\hline
\end{tabular}

\begin{tabular}{rrr|rr|r} 
NE-44 & 67189 & 18480 & 335399 & 1634088 & 249587 \\
\hline$C 0.45$ & 46065 & 43 & 291862 & 127455 & 41931 \\
46 & 0 & 4 & 46289 & 14534 & 6082 \\
47 & 256 & 119 & 56421 & 6106 & 6252
\end{tabular}

\begin{tabular}{rrr|rr|r|}
47 & 256 & 119 & 56421 & 6106 & 62526 \\
48 & 140 & 192 & 27644 & 4724 & 32368
\end{tabular}

\begin{tabular}{rrr|rr|r}
50 & 19 & 46 & 2890 & 5143 & 8033 \\
51 & 39 & 405 & 3121 & 5947 & 9068 \\
52 & 3500 & 15 & 1292 & 2829 & 4121 \\
52 & 6 & 13893 & 16986 & 30079
\end{tabular}

\begin{tabular}{rrr|rr|r|r|}
52 & 3500 & 8 & 13893 & 16986 & 30079 \\
53 & 68 & 142 & 16080 & 5598 & 21578 \\
54 & 0 & 3 & 3672 & 216 & 3888 \\
55 & 96 & 661 & 116937 & 20975 & 137912 \\
\hline & & & 3921 & & \\
\hline
\end{tabular}

\begin{tabular}{rrr|rr|r|}
55 & 96 & 661 & 116937 & 20975 & 137912 \\
56 & 2 & 26 & 3421 & 1281 & 16232 \\
57 & 1 & 2 & 3021 & 187 & 3207 \\
5 & 0 & 164 & 25959 & 13548 & 3950 \\
\hline & 3939 & & & 33309 & 2529 \\
\hline
\end{tabular}

\begin{tabular}{rrr|rr|r}
58 & 9 & 164 & 25958 & 13648 & 39606 \\
59 & 3833 & 8 & 1955 & 23309 & 25264 \\
60 & 38234 & 398 & 63429 & 120481 & 183910 \\
61 & 3 & 14 & 352 & 575 & 1425 \\
& 4189 & 234 & 55152 & 29017 & 845
\end{tabular}




\section{ANEXO C}

Tabela C.1: Versão completa da matriz de insumo produto inter-regional para o Brasil, 1995. Em mil reais.

Fonte: dados da pesquisa. 
183

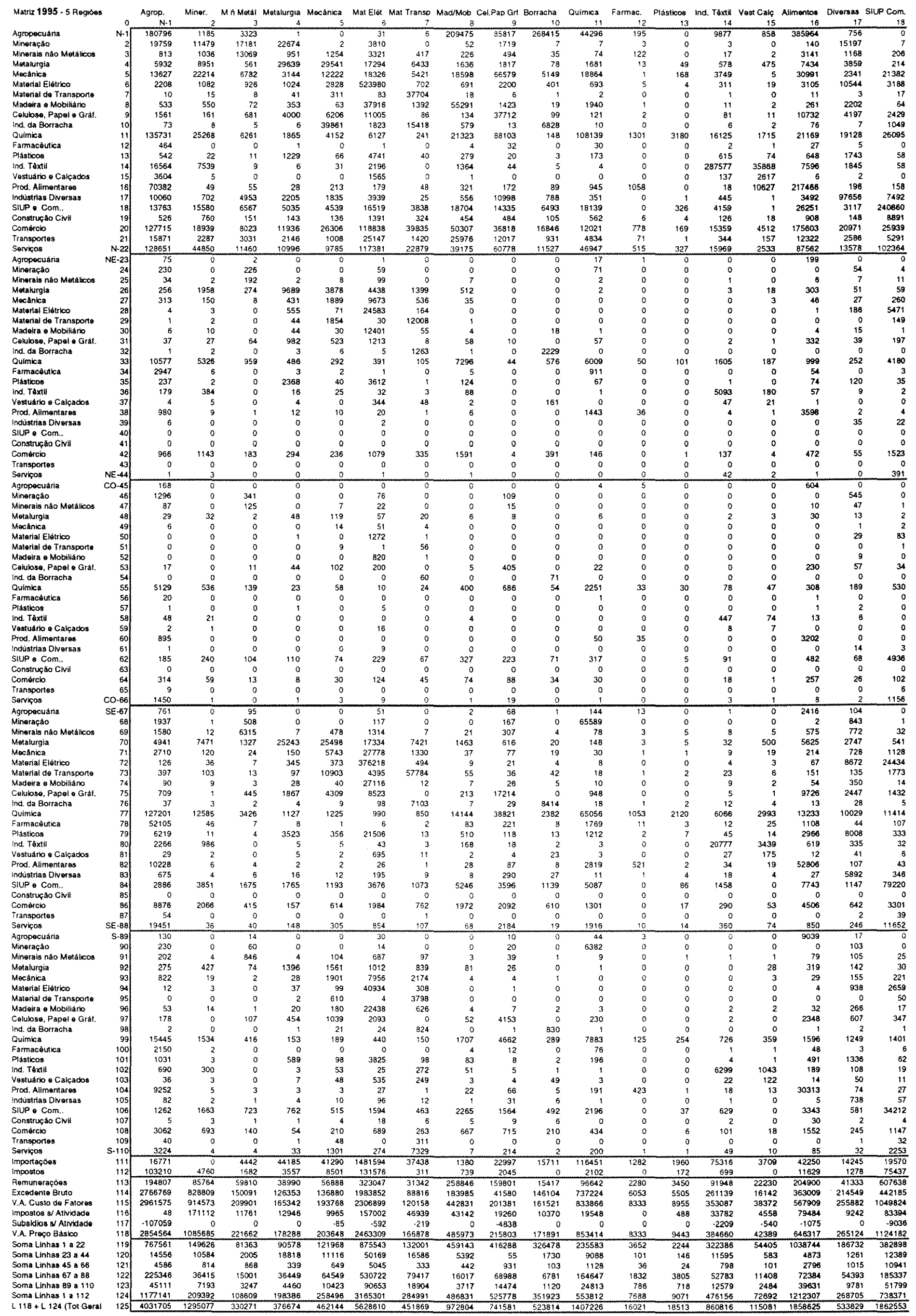




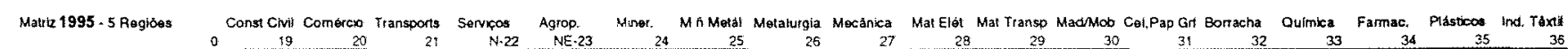

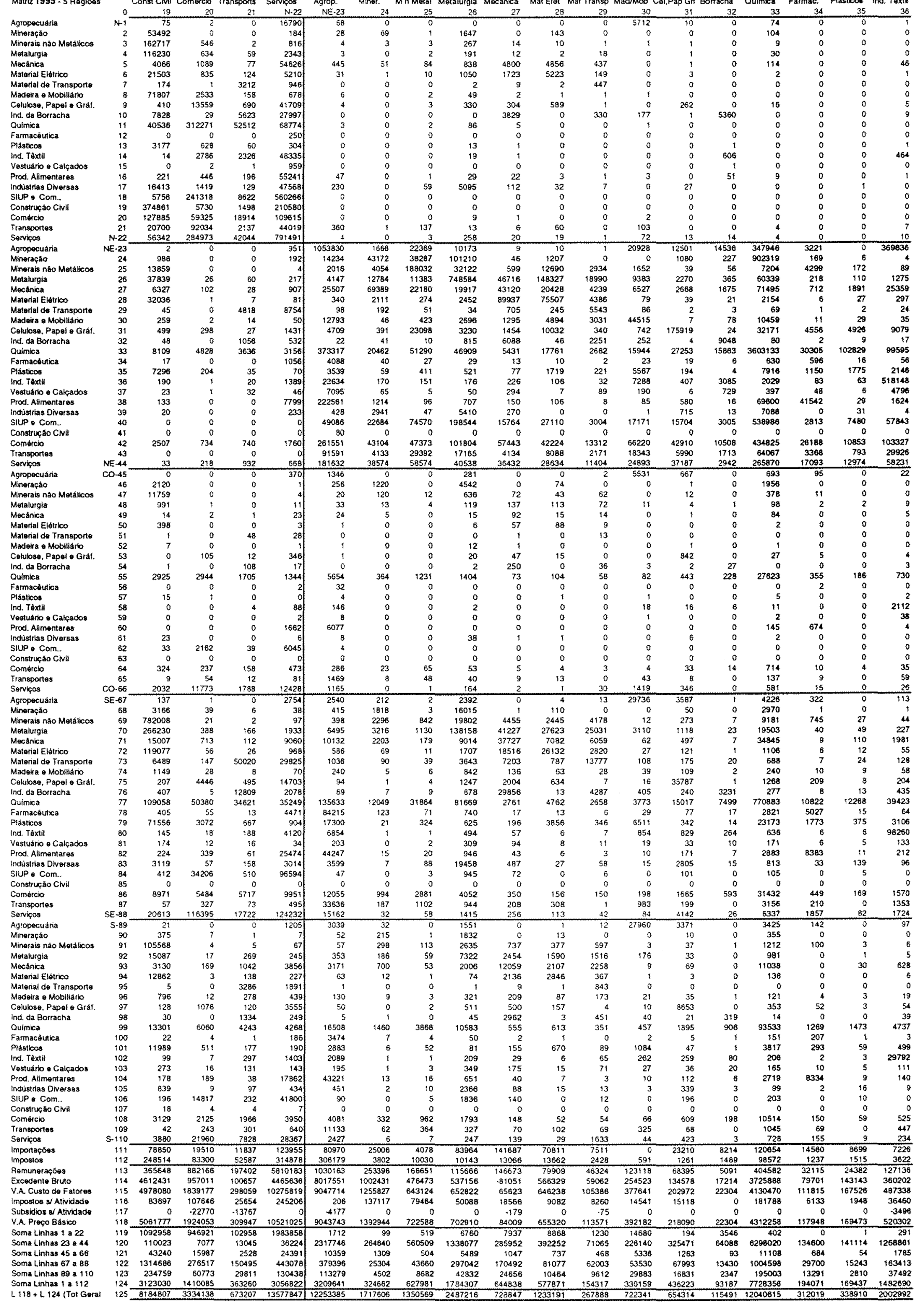




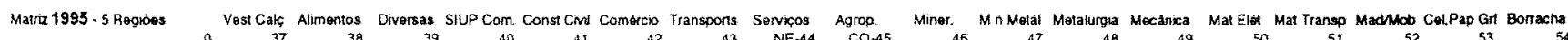

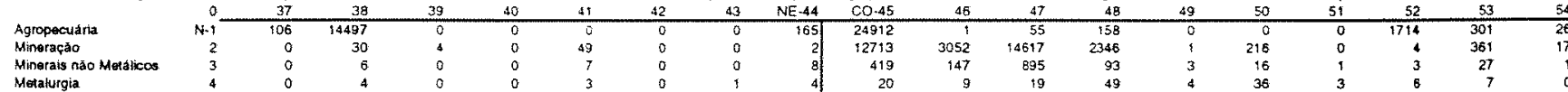
Mecanica

Materfal Elatrico

Madoira e Mobitianto

Colubse, Papel o Gr

Quimica

Plasticos
Ind. Taxtil

Vostuario Cakcados Prod. Alsmentates

SIUP Com.

Compreto

Transport

Agropeculán

Mineraçăo
Minerais nà Miqualicos Metakuigla

Macanica

Material de Transpont Cetulose, Papal 0 Grát. Ind. da Borracha

Farmacaluica

Pfásticos

Vestuario Calçacos

Indústrias DNarsas

Construça $\mathrm{CN}$

combrcio

Transportos

Agropecuaria

Minerais nào Metálico

Motalurgia

Matarial Elatitioo

Material de Transporte

Cetulose, Papai is Grát.

Ind. da Borracha

Farmacática

Plástitos

Vestuarto Cakados

Prod. Alimentar

SIUP C Com.-

Comérclo

Transportes
Servicos

Agropecuária

Mineraçào

Metaturgira

Material Elétsico

Malerial de Transports

Cetulase, Papal a Grá

Quimica

Farmacén

ind. Tóxtil

Yestuário Calçados industrias Diversas

SIUP * Com..

Construcia
Comárcio

Transportias

Servicas

Agropecuana

Minerais náo Metallicos

Metalurgia

Mactanica

Matertal do Transporte

Calulose, Papel e Grá.

Indi. da Berfachia

Fuimica

Plásticos

Vestuario Calcacios

Prod. Altmentares

SIUP a COM.

Constructo CA

Transportes

Senviço

Imposios

Remuneraćías

Excedente Bruto

Impostos a Atwidade

V.A. Proço Basico

Soma Linhas is 22

Soma linhas 45 a 66

Soma Limhas 67 a 88

Soma Linhas i a 112

L $118+L 124$ (Tot Gora)

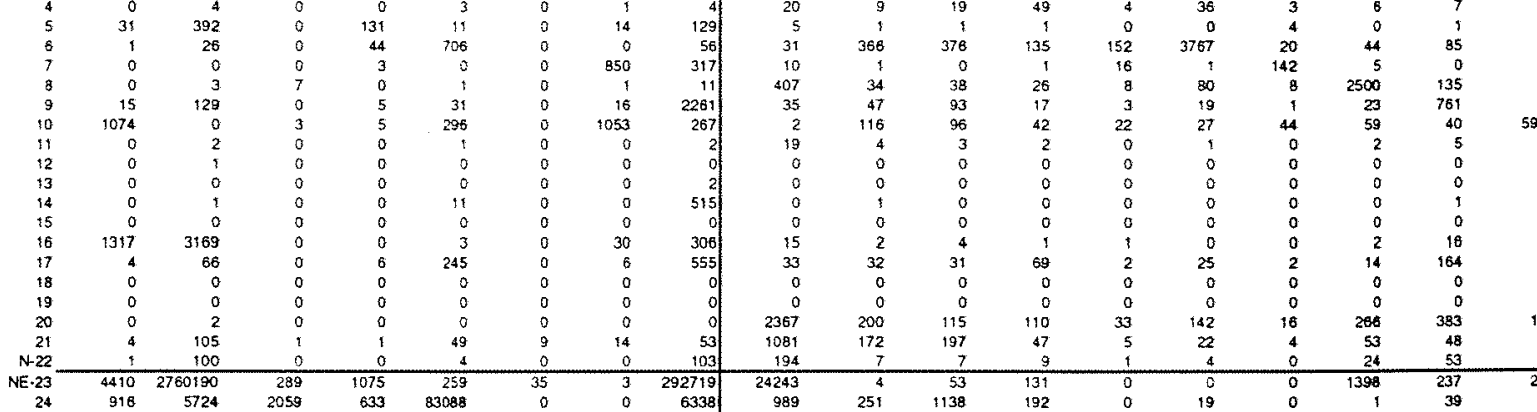

\begin{tabular}{|c|c|c|c|c|c|c|c|c|c|c|c|c|c|c|c|c|c|c|}
\hline $\mathrm{NE} \cdot 23$ & 4410 & 2760190 & 289 & 1075 & 259 & 35 & 3 & 292719 & 24243 & 4 & 53 & 131 & 0 & 0 & o & 1398 & 237 & 21 \\
\hline 24 & 918 & 5724 & 2059 & 633 & 83088 & 0 & 0 & 6338 & 989 & 251 & $\$ 138$ & 192 & 0 & 19 & 0 & 1 & 39 & \\
\hline 25 & 366 & 21874 & 315 & 57 & 856711 & 0 & 0. & 7898 & 147 & 48 & 301 & 31 & 9 & 6 & 0 & 2 & 11 & \\
\hline 26 & 1137 & 22724 & 616 & 2214 & 238922 & 24 & 558 & 11238 & 110 & 262 & 198 & 1880 & 135 & 297 & 57 & 108 & 34 & \\
\hline 27 & 6253 & 43330 & 111 & 112741 & 98137 & 0 & 247 & 35842 & 15 & 21 & 9 & 18 & 3 & 15 & 5 & 9 & 2 & $\uparrow$ \\
\hline 28 & 65 & 574 & 81 & 26868 & 78325 & 0 & 63 & 24730 & 4 & 4 & 3 & $a$ & 20 & 132 & 2 & $i$ & $i$ & 0 \\
\hline 29 & 5 & 104 & 0 & 543 & 455 & 18 & 42667 & 30018 & 3 & 1 & 0 & 0 & 5 & 0 & 42 & 1 & 0 & \\
\hline 30 & 3729 & 1613 & 509 & 17 & 172512 & $\$ 3987$ & 1991 & 41445 & 6 & 2 & $i$ & 1 & 0 & 1 & 0 & 2 & 1 & 1 \\
\hline 31 & $\$ 1950$ & 57484 & 74 & 7072 & 8600 & $158 \mathrm{a} 2$ & 4000 & 191236 & 16 & 5 & 6 & 3 & 1 & 3 & 0 & 3 & 3 & 1 \\
\hline 32 & 10292 & 32 & 0 & 192 & 4879 & 0 & 17910 & 2319 & $t$ & 11 & 9 & 4 & 2 & 3 & 4 & 6 & 4 & 55 \\
\hline 33 & 43057 & 62483 & 1720 & 33521 & 220051 & 1300561 & $18 \mathrm{~B} 233$ & 158a74 & 25119 & 1601 & 4223 & 997 & 66 & 633 & 58 & 1636 & 2529 & 1397 \\
\hline
\end{tabular}

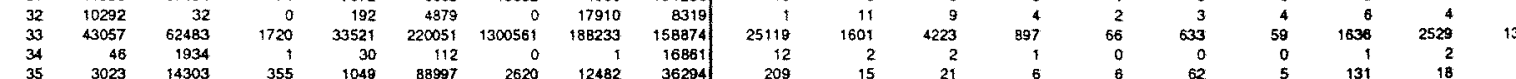

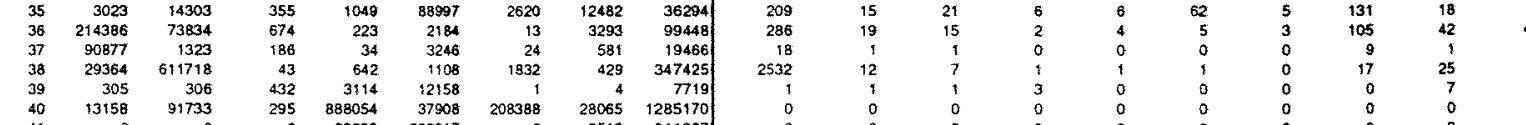

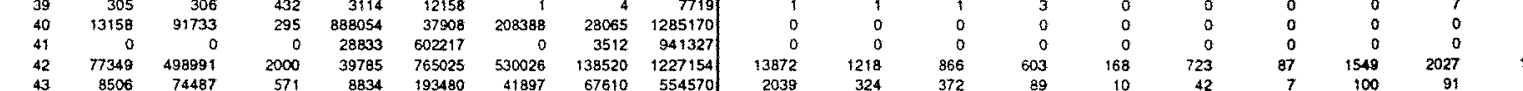

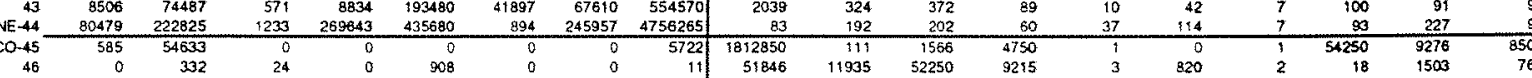

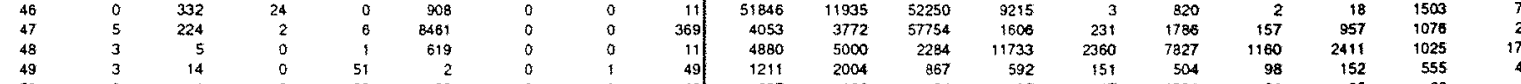

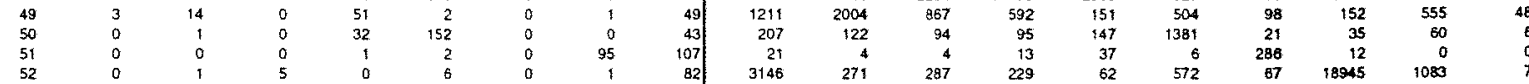

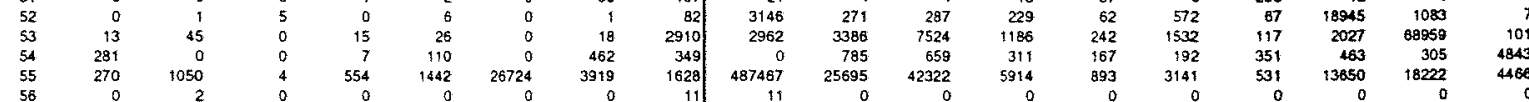

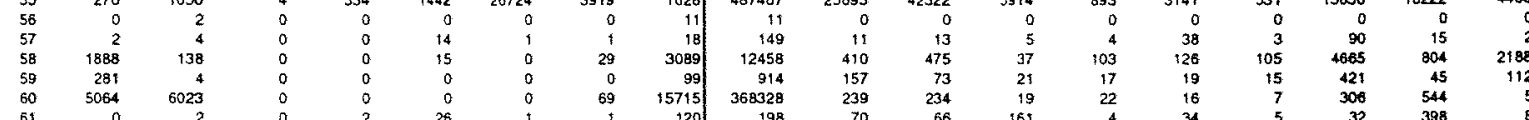

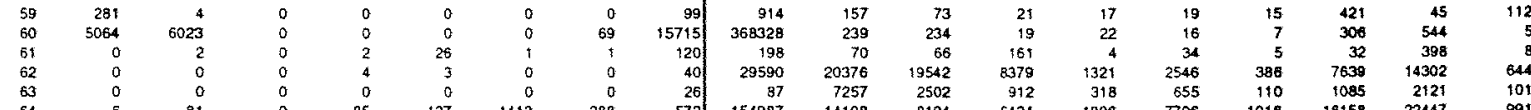

\begin{tabular}{|c|c|c|c|c|c|c|c|c|c|c|c|c|c|c|c|c|c|}
\hline 63 & 0 & 0 & 0 & 0 & 0 & 0 & 26 & 87 & 7257 & 2502 & 912 & 318 & 655 & $1 \neq 0$ & 1085 & 2121 & to \\
\hline 64 & $8 t$ & 0 & $B 5$ & $\$ 27$ & 1412 & 288 & 572 & 154987 & 14108 & 8194 & 6424 & 1900 & $\pi \infty$ & 1018 & $16+58$ & 22447 & $\infty$ \\
\hline 25 & 157 & 2 & 32 & 406 & 35 & +37 & 1244 & 14a968 & 21067 & 23628 & 6147 & 747 & 2510 & 530 & 7341 & 6574 & \\
\hline 35 & 14808 & 0 & 1407 & 848 & 3 & 94 & $\{6143$ & 570018 & 144503 & 44522 & 20557 & 4157 & 18089 & 2114 & 34673 & 73168 & 243 \\
\hline 5806 & 168823 & 6 & 0 & 59 & 0 & 0 & 36302 & 27822 & 4 & 7 & 2 & 0 & 7 & 0 & 217 & 30 & \\
\hline
\end{tabular}

\begin{tabular}{|c|c|c|c|c|c|c|c|c|c|c|c|c|c|c|c|c|c|c|}
\hline SE.67 & 5806 & 168823 & 6 & 0 & 59 & 0 & 0 & 36302 & 27822 & 4 & 7 & 2 & 0 & 7 & 0 & 217 & 30 & 7 \\
\hline 68 & & 526 & 36 & ; & 1406 & 103 & 13 & 548 & 22 & 17366 & 1039 & 2016 & 0 & $\infty$ & 0 & 2 & 216 & 16 \\
\hline 69 & 306 & 13199 & 33 & 390 & 566135 & 149 & 5 & 20127 & 570 & 48 & 47 & 21 & 6 & 28 & 3 & 34 & 49 & 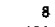 \\
\hline 70 & 221 & 1996 & 2 & 469 & 281902 & 912 & 436 & 5957 & 7535 & 16354 & 11210 & 88379 & 8934 & 16750 & 3912 & 7237 & 2696 & 464 \\
\hline 71 & 1243 & 5787 & $i$ & 21016 & 6930 & 10 & 250 & 22136 & 9312 & 16602 & 7162 & 5248 & 1267 & 4452 & 832 & 1357 & 4776 & 420 \\
\hline 72 & 37 & 240 & a & 9572 & 45843 & 40 & 58 & 12858 & 450 & 1137 & 703 & 689 & 1070 & 9564 & 154 & 211 & 310 & 43 \\
\hline 73 & 121 & 430 & a & 2234 & 4402 & 38 & 98920 & $\{20942\}$ & 1565 & $9 \mathrm{BO}$ & 352 & 442 & 998 & 423 & 5679 & 595 & 250 & $\pi 7$ \\
\hline 74 & 67 & 211 & 148 & 24 & 332 & 38 & 38 & 3608 & 2041 & 225 & 85 & 183 & 48 & 390 & 45 & $1+780$ & 758 & 11 \\
\hline 75 & 589 & 1992 & 0 & 662 & 1316 & 17 & $76 !$ & 124055 & 2080 & 2694 & 5953 & 955 & 190 & 1215 & 94 & 1608 & 54613 & 80 \\
\hline 76 & 33434 & 47 & 45 & 380 & 13257 & 6 & 55012 & 41902 & 238 & 1638 & 1352 & 661 & 342 & 403 & 712 & 957 & 681 & 9775 \\
\hline$\pi$ & 17385 & 33115 & 276 & $\begin{array}{r}12672 \\
\end{array}$ & 53517 & 550811 & 80846 & 50316 & 541990 & 17638 & 28478 & 5960 & 704 & 3324 & 518 & $\$ 2285$ & 20012 & 4790 \\
\hline 78 & 147 & 1702 & ; & 170 & 96 & 289 & 28 & 26726 & 2277 & 211 & 108 & 54 & 3 & 13 & 1 & 92 & 153 & 17 \\
\hline 79 & 3182 & +8919 & 4 & 1500 & 63460 & $6 \$ 74$ & 4752 & 73222 & 14310 & 919 & 1216 & 427 & 388 & 3763 & 314 & 8794 & 1318 & 86 \\
\hline 80 & 87966 & 6512 & 0 & 36 & 365 & $\$ 1$ & 1359 & 144353 & 6081 & $26 \%$ & 238 & $\$ 2$ & 54 & 78 & 55 & 2295 & 506 & 1063 \\
\hline 91 & 9062 & 92 & 0 & 14 & 221 & 18 & 69 & 1363 & 577 & 209 & 62 & 47 & 19 & 35 & 77 & 345 & 79 & 47 \\
\hline 82 & 41438 & 70430 & 1 & 47 & 160 & 20 & 505 & 166004 & 8063 & 128 & 72 & 69 & 5 & 28 & 3 & 87 & 296 & t3 \\
\hline 83 & 198 & 708 & 5 & 479 & 8540 & 66 & 380 & 57718 & 1696 & 619 & 583 & 1437 & 33 & 207 & 45 & 237 & 3570 & 102 \\
\hline 84 & 11 & 43 & 0 & 13 & 91 & 0 & 4 & 724 & 7 & 87 & 20 & 69 & 5 & 22 & 6 & 16 & 127 & \\
\hline 35 & 1. & 0 & 0 & 0 & 0 & 0 & 0 & 191 & 0 & 0 & 0 & 0 & 0 & 0 & 0 & 0 & 0 & 0 \\
\hline
\end{tabular}

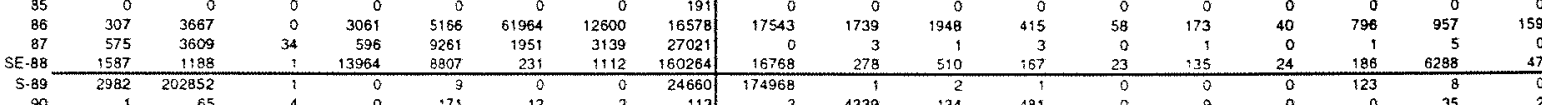

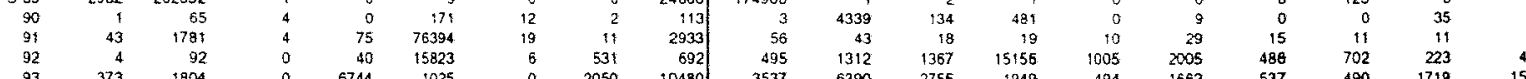

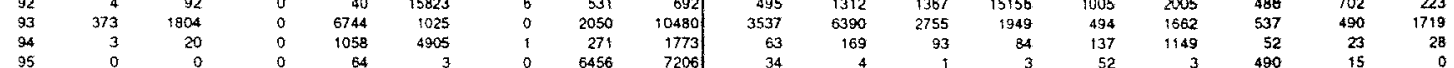

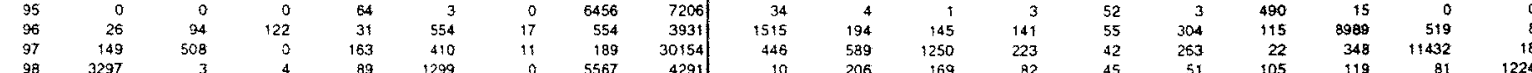

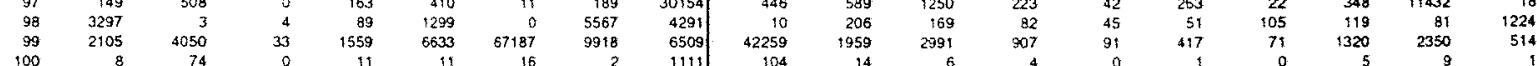

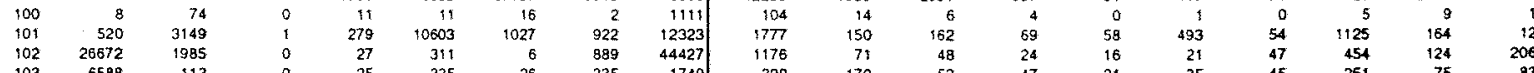

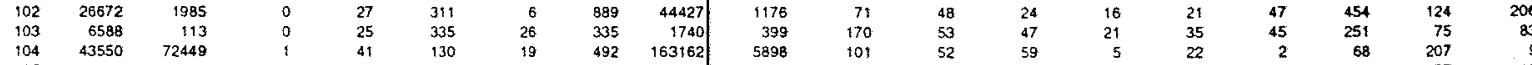

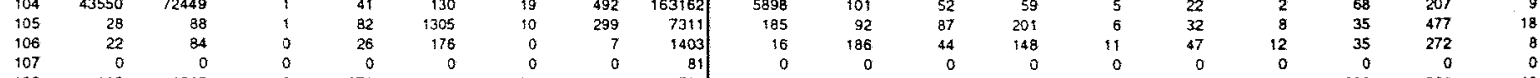

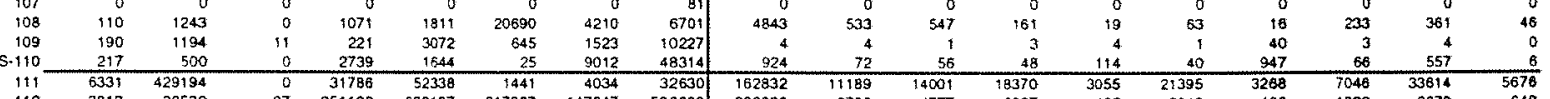

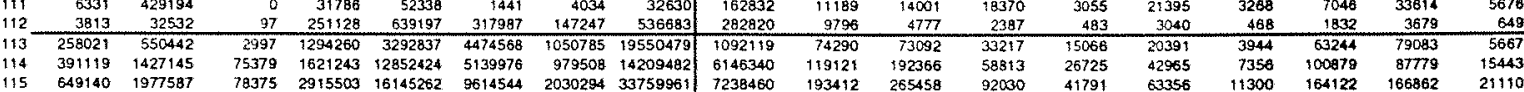

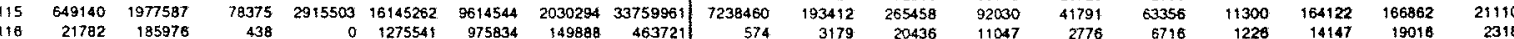

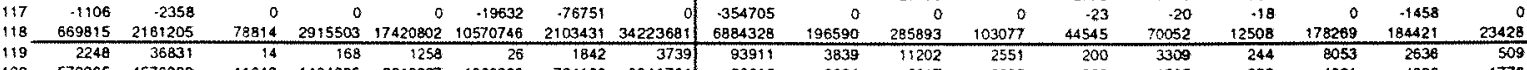

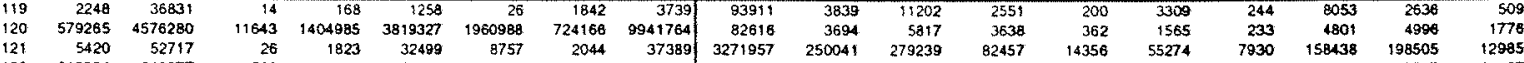

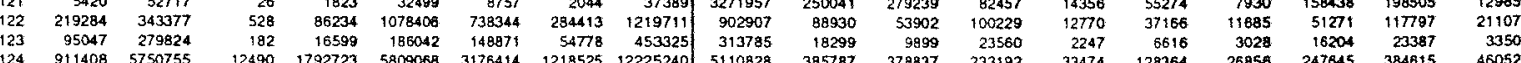

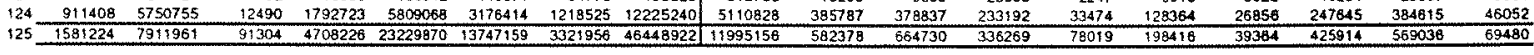




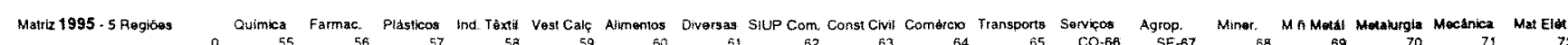

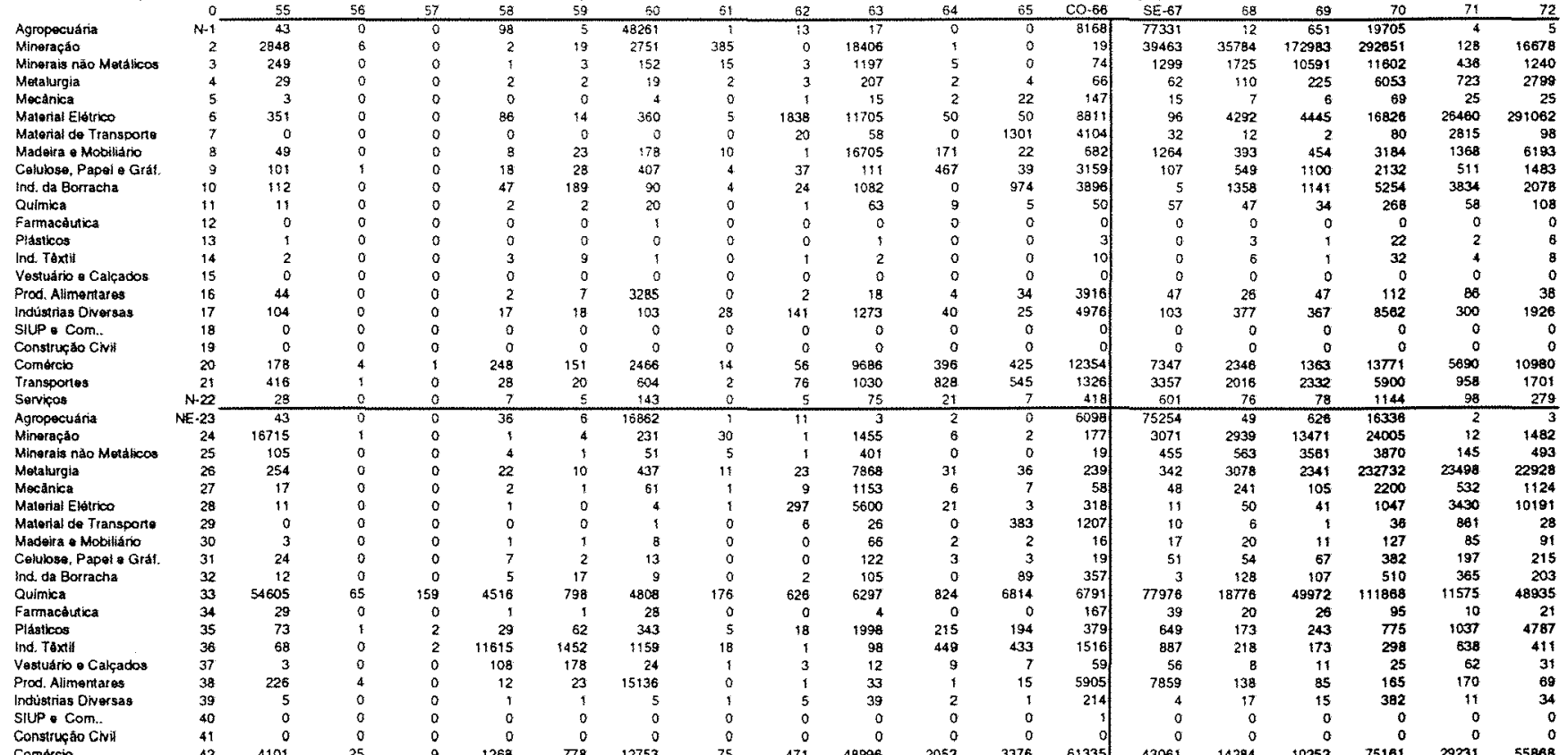
Transportios Servicos Agropecuátia Minerais náo Matálicos Motalutgia

Material Elátrico. Maternal de Tzansporte
Madeira o Mobilitio Colubse, Papai i Grat.
ind. da Borracha Química Farmacêutic

ind. Toxtll

Vestuario o Calcados inckistrias Divergas

Stup o Com.

Comśricio

Transportes

Agropecuária

Minorais nắo Mot́́lico Metalurgia

Material Elétrico Material de Transports

Colubse. Papal a Gtal

Farmacóurica

Písticos

Vestuário o Cakcados Indtustrias Diversas

Gonstruçāa Givi

Comarcio

Servicos

Agropocuana

Mineracąo

Minerais nao Metálicos Mocanica

Materiat Elético
Material de Transpon

Madvira o Mobilatio

Celubose, Papel e
Ind. da Borrach

Quimica

Plasticos

Yind. Toxtil

Prod. Aliment ares

Industnas ONersas
SIUP o Com.

Construça do CN

Transportes

Servicios

Importaço
Impostos

Remunoraçós

Excodente Brufo

Impostos s/ Atvidade

V.A. Proço Básico

Soma Linhas 1 \& 22

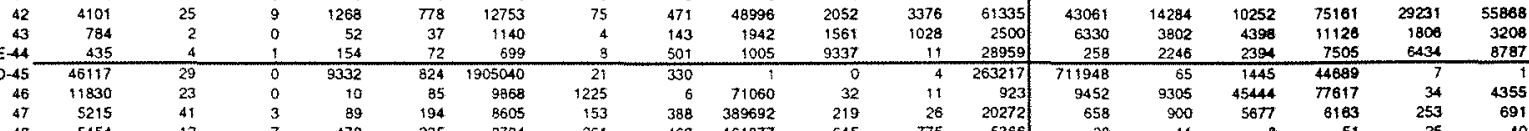

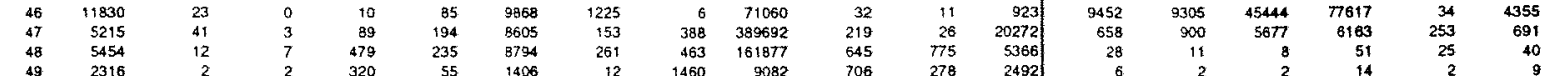

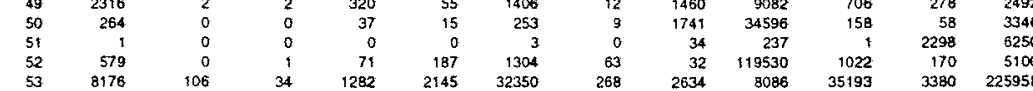

$\begin{array}{rrrrrrrrrrrrr}53 & 8176 & 106 & 34 & 1282 & 2145 & 32350 & 268 & 2634 & 3086 & 35193 & 3380 & 2259 \\ 54 & 897 & 2 & 2 & 314 & 1332 & 500 & 26 & 157 & 7950 & 0 & 7163 & 2373 \\ 55 & 328682 & 332 & 386 & 10876 & 2925 & 45922 & 425 & 12123 & 197448 & 392803 & 148055 & 101391\end{array}$

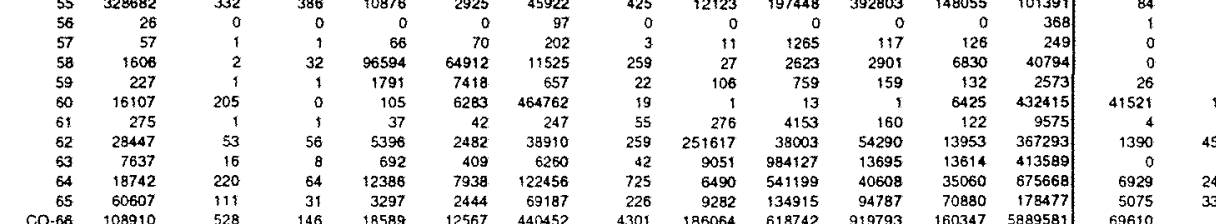

Soma Linhas 23 a 44
Soma Linhas 45 a 66

Soma Linhas 67 a 88

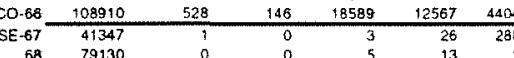

$\begin{array}{rrrrrrr}69 & 266 & 1 & 1 & 20 & 11 & 74 \\ 70 & 17524 & 28 & 10 & 1046 & 798 & 2550\end{array}$

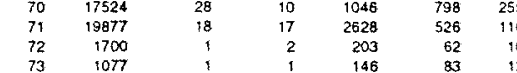

$\begin{array}{rrrrrrr}73 & 1077 & 1 & 1 & 146 & 83 & 1320 \\ 74 & 527 & 1 & 2 & 78 & 159 & 7005 \\ 75 & 6586 & 84 & 27 & 1015 & 1714 & 25450 \\ 76 & 2037 & 4 & 5 & 573 & 394 & 1927\end{array}$

$\begin{array}{rrrrrrr}76 & 2586 & 84 & 27 & 1015 & 1714 & 25 \\ 77 & 224796 & 280 & 54 & 673 & 2724 & 1291 \\ 78 & 2511 & 8 & 1 & 15189 & 3941 & 29278\end{array}$

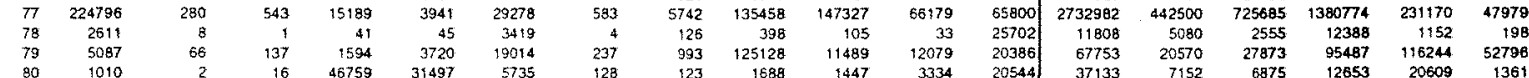

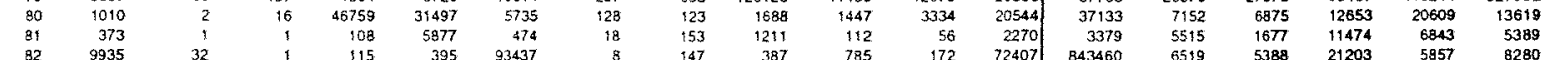

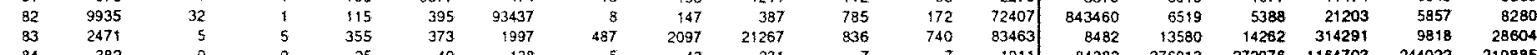

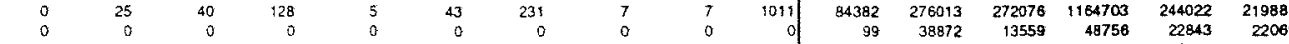

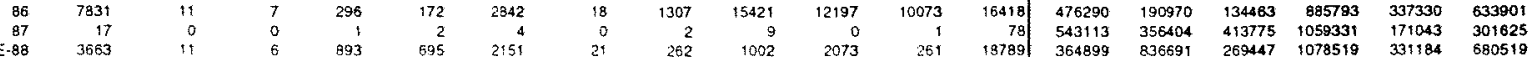

Soma Linhas i a 112

\begin{tabular}{|c|c|c|c|c|c|c|c|c|c|c|c|c|c|c|c|c|c|c|}
\hline & & & & & & & & & & & & & & & & & & \\
\hline S-89 & 2050 & 0 & 0 & 1 & 10 & 43582 & 0 & 0 & 90 & 7 & 9 & 3098 & 1590755 & 192 & $45 \pi$ & 121758 & 7 & 64 \\
\hline 90 & 11410 & 0 & 0 & $i$ & 3 & 35 & $i$ & 56 & 33 & 9 & 3 & 181 & 663 & 653 & 3186 & 5443 & 2 & 300 \\
\hline 91 & 52 & 0 & 0 & 4 & 2 & 33 & 0 & 24 & 609 & $\mathfrak{i n}$ & 7 & 358 & 545 & 761 & 4879 & 5243 & 185 & 530 \\
\hline 92 & 1473 & 2 & i & 71 & 47 & 1934 & 61 & 125 & 43859 & 136 & 475 & 1917 & 2 & 1 & ; & 6 & 3 & \\
\hline 93 & 7323 & 7 & 6 & 991 & 162 & 4296 & 38 & 4513 & 31001 & 2144 & 1979 & 12742 & 7 & $x$ & 4 & 19 & 2 & 19 \\
\hline 94 & 179 & 0 & 0 & 24 & 3 & 117 & 6 & 1457 & 28668 & 111 & 192 & 3035 & 5 & 2 & 1 & 9 & 4 & 7 \\
\hline 95 & i & 0 & 0 & 0 & 0 & 8 & 0 & 51 & 132 & 0 & 3979 & 10799 & 0 & 0 & 0 & 0 & 0 & \\
\hline 96 & 311 & 0 & 1 & 40 & 96 & 717 & 31 & 37 & 58010 & $51 \%$ & 415 & 4615 & 6877 & 2246 & 2658 & 18997 & 8328 & 37815 \\
\hline 97 & 1494 & 18 & 6 & 220 & 372 & 5360 & 46 & 448 & 1407 & 5819 & 558 & 37574 & 7 & 2 & 2 & 13 & E & 16 \\
\hline 98 & 241 & 0 & $i$ & 81 & 338 & 158 & 7 & 4 & 2059 & 2 & 1836 & 6281 & ; & $i$ & 0 & 3 & 1 & \\
\hline 99 & 22042 & 30 & 58 & 1542 & 459 & 3150 & 68 & 620 & 14926 & 14519 & 6702 & 7595 & 100 & $2 \theta$ & 50 & 158 & 50 & a3 \\
\hline 100 & 115 & 0 & 0 & 2 & 3 & 134 & 0 & 11 & 22 & 6 & 2 & 979 & 34 & 4 & 1 & 7 & 2 & $x$ \\
\hline 104 & 656 & a & 17 & 197 & 467 & 2417 & $3 \mathfrak{1}$ & 138 & 16195 & 1450 & 1600 & 2926 & 16 & $f$ & 8 & $5 t$ & 28 & 118 \\
\hline 102 & 263 & 0 & 3 & 8946 & 6036 & 1146 & 26 & 64 & $55 t$ & 284 & 935 & 5012 & 24 & 9 & 2 & 25 & 16 & 28 \\
\hline 103 & 343 & I & 1 & 70 & 3855 & 399 & 14 & 125 & 1186 & 92 & 197 & 2552 & 618 & 923 & 264 & 1289 & 1129 & s87 \\
\hline 104 & 2000 & 20 & 0 & 63 & 264 & $30 \pi 7$ & 6 & 107 & 342 & 328 & 62 & 26972 & 373140 & 1296 & 1347 & 1293 & 1684 & 757 \\
\hline 105 & 333 & : & ? & 46 & 50 & 292 & 66 & 301 & 4322 & 122 & $20 \gamma$ & 11605 & 13 & , & 10 & 17 & 1 & 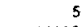 \\
\hline 106 & 815 & I & 0 & 53 & 85 & 274 & 10 & $9 f$ & 494 & 15 & 15 & 2160 & 5487 & 17931 & 17688 & 74855 & $\$ 5788$ & 14110 \\
\hline 107 & 0 & 0 & 0 & 0 & 0 & 0 & 0 & 0 & 0 & 0 & a & of & 124 & 212 & 148 & $115 t$ & 472 & 790 \\
\hline 108 & 2262 & 3 & 2 & 100 & 78 & 872 & g & 387 & 4437 & 3367 & $27 \mathrm{st}$ & 5563 & 18656 & 6508 & 3847 & 38795 & 15858 & 30375 \\
\hline 109 & 14 & 0 & 0 & i & I & 4 & 0 & 5 & 32 & 0 & 299 & 1615 & 23620 & 15408 & 17909 & 46023 & 7410 & 13005 \\
\hline $5-110$ & 320 & 1 & $i$ & 85 & 87 & 209 & 3 & 114 & 897 & 180 & 5462 & 30683 & $\$ 167$ & 34 & 43 & 591 & 76 & $15 t$ \\
\hline 111 & 331869 & 577 & 203 & 43933 & 14763 & 119310 & 779 & 64158 & 214944 & 55646 & 176057 & 485104 & 387889 & 118552 & 211115 & 2442927 & 583111 & 1850891 \\
\hline 112 & 43022 & gi & 30 & 4580 & 3449 & 74313 & 289 & 67368 & 1511615 & 135473 & 102009 & 1129776 & 673718 & 103800 & 72035 & 317486 & 92992 & 263003 \\
\hline 113 & 166508 & 759 & 499 & 34958 & 52049 & 340014 & 4123 & 499446 & 786261 & 1177299 & 388566 & 15767168 & 2601588 & 787160 & 1102098 & 9417335 & 2900082 & 1764051 \\
\hline 114 & 743941 & 15 & B & & 52366 & 608840 & 5432 & 550485 & 5770559 & 1771129 & 451135 & $107 m 713$ & 14641479 & 1262178 & 2900540 & 7821152 & 5144512 & 3718990 \\
\hline 115 & 910449 & 2329 & 1370 & 114350 & 104415 & 948854 & 9555 & 1039930 & 6556820 & 2888428 & 239701 & 26544882 & 17243067 & 2049338 & 4002635 & 12238487 & Bo4459 & 5431041 \\
\hline 196 & 89408 & 192 & 129 & 14920 & 19056 & 165428 & 871 & 72289 & 379757 & 156251 & 62507 & 893091 & 660 & 33679 & 308136 & 1489069 & 534450 & 581010 \\
\hline 117 & & & 0 & .1772 & -1 & -2240 & & .7056 & 4118 & .26843 & $.3822 \theta$ & & .844960 & & 0 & & -4364 & 1894 \\
\hline 138 & 999857 & 2521 & 1499 & 127498 & 114292 & 1112042 & 10426 & 1705164 & 6932459 & 3017835 & 963979 & 27437973 & $1639 \mathrm{~B} 766$ & 2083017 & 4310771 & 13707544 & 8574680 & 6060357 \\
\hline 119 & 5438 & 13 & 3 & 747 & 462 & 152898 & 402 & 1780 & 52926 & 4178 & 4956 & 67566 & & 40579 & 168907 & 339187 & 38507 & 286234 \\
\hline 120 & 9171 & . & 177 & 0169 & 3660 & & 3 & 1590 & 52312 & $\$ 2215$ & 12640 & $11: 520$ & 196803 & 39138 & 87704 & & 69722 & 135378 \\
\hline 121 & 483813 & 1581 & 583 & 140000 & 97705 & 2967584 & 8071 & 487181 & 3497963 & 1443355 & 419975 & 8469601 & 575267 & 22751 & 64150 & 177384 & 18493 & 33248 \\
\hline 122 & 553545 & 628 & 918 & 88681 & 66047 & 320961 & 2800 & 39679 & 1106466 & 299891 & 196286 & 903951 & 8450283 & 3589383 & 5103834 & 26494787 & 5354490 & B159123 \\
\hline 123 & 82227 & 128 & 154 & $\$ 4396$ & 13996 & 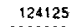 & 529 & 7341 & 205670 & 51249 & 39352 & 222549 & 1865277 & 44845 & 62245 & 300008 & 51037 & 100405 \\
\hline 124 & 1591085 & 3107 & 2067 & & 981 & & 3202 & 669081 & 6641897 & 2008008 & 951275 & 11390068 & 12372947 & 3959659 & 5769990 & 0555498 & B213357 & 10828278 \\
\hline 125 & 2590942 & 5628 & 3567 & 440009 & 314272 & 4938075 & 23628 & 1774226 & 13574356 & 5025843 & 1815255 & 38828041 & 28771714 & 6042676 & 10080765 & 44263033 & 14788037 & 16889638 \\
\hline
\end{tabular}




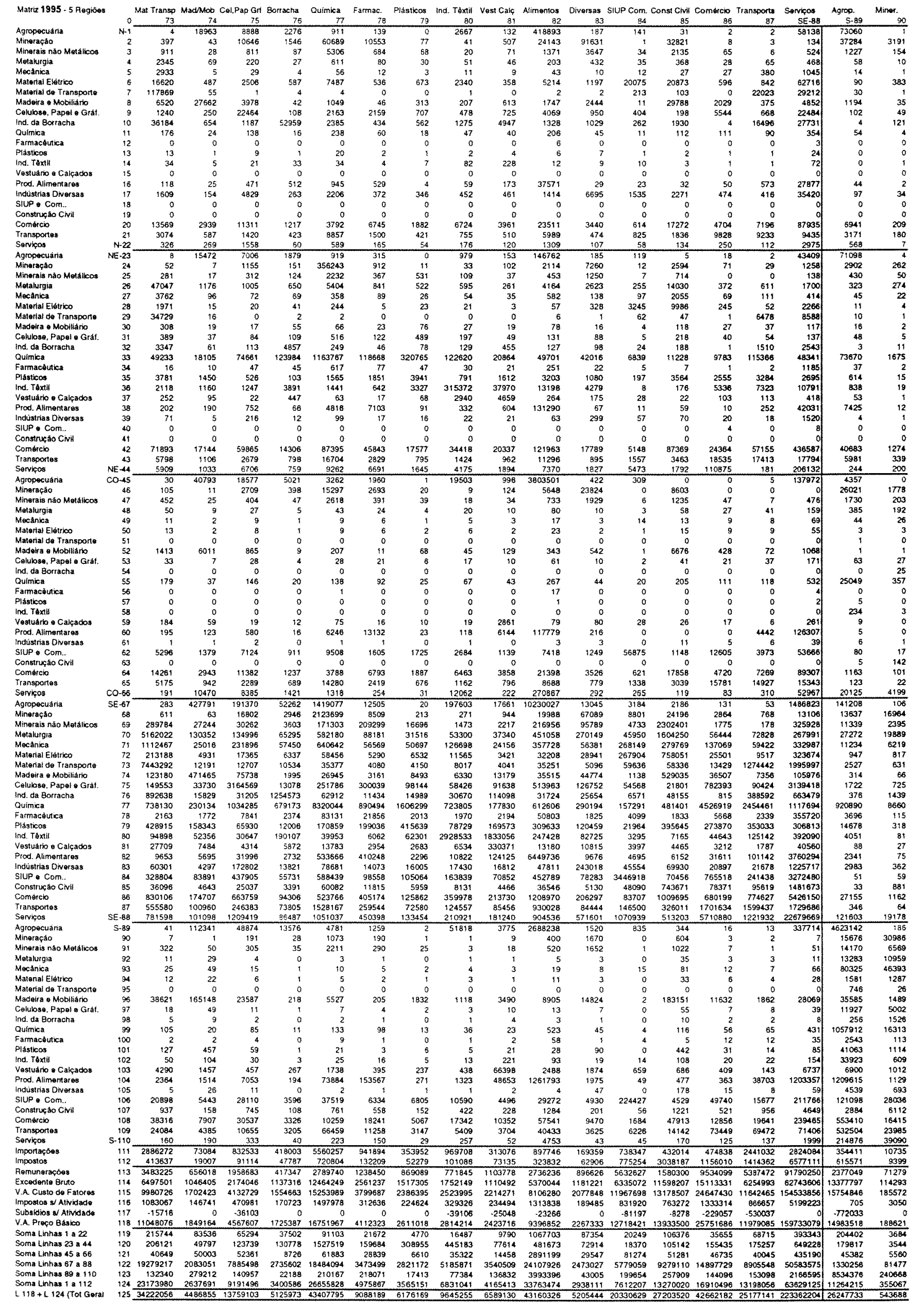




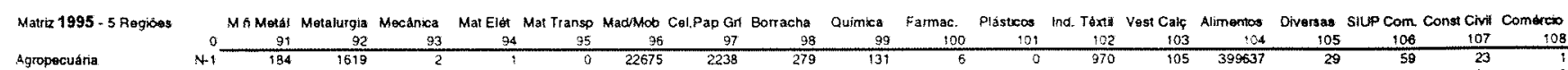

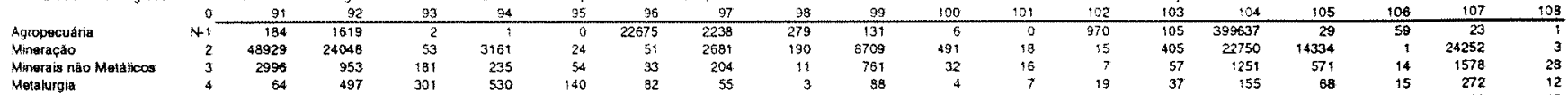

Material Es Estrico Material de Transporte
Madeita o Mobilianio Colubse, Papel o Grat Gúmica Farmacóutica Pfasticos Text! Vestuano o Catçados Incustrias Diversa SiUP o Conn.. Combrcio Servicos Agropecuatria
Mizeraçăo Minerais năo Matálícos Moctalurgia Material Elattrico Maderial o Mo Transporliario ind da Borracha

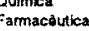

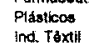
Vostudio e Calçados Prod. Alimentar Construça áo Cvil Transportes Servicos Agropecuári Minerais náo Metalicos Mrtalusgia
Mreanka

Material Elátrico Matenal de Transporte
Madeira o Mobilianc Colubse. Papel o Grá. ind. da Borrach
Quimica Famamea ducter

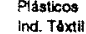
Vestuáno Calçádos industrias DNersas SIUP a Com.. Comarcio Transportes
Senvicos Agropecuaria Mingrais náo Meráicos Motalurgia

Material Elático Material de Transporte Colulaso. Papel o Gra Ind. da Borracha

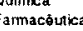

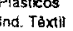

ostudrio o Caląados Prod. Almentayos SIUP o Com.

Comercto

Transport

Sarvess

Mineraçăo Metaburgia

Matânica Material de Transporte Colulase. Papel o Grat, Ind. de Borracha

Famainica Pláathos

Vestuario Calçados Prod. Allmantares. SIUP : Com. Comercio

Sarveos

Imporaticoes
Imposios Remunaracóos Excodente Bruto
V.A. Custo do F atoros V.A. Custo do Fatores Subsidios a/ Atividact Soma Lithia 1 a

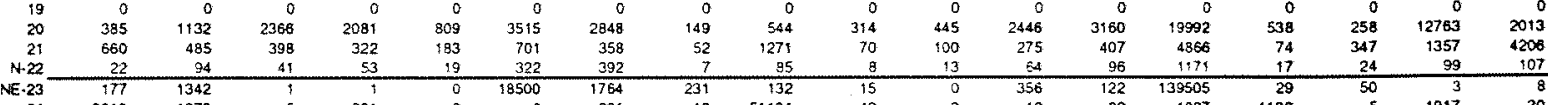

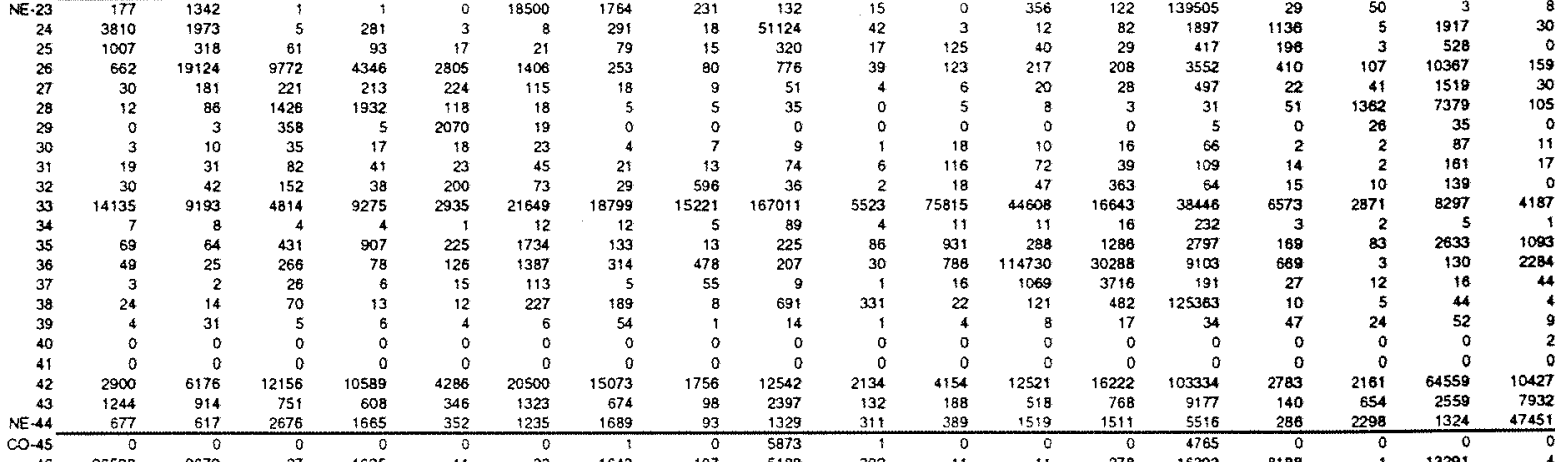

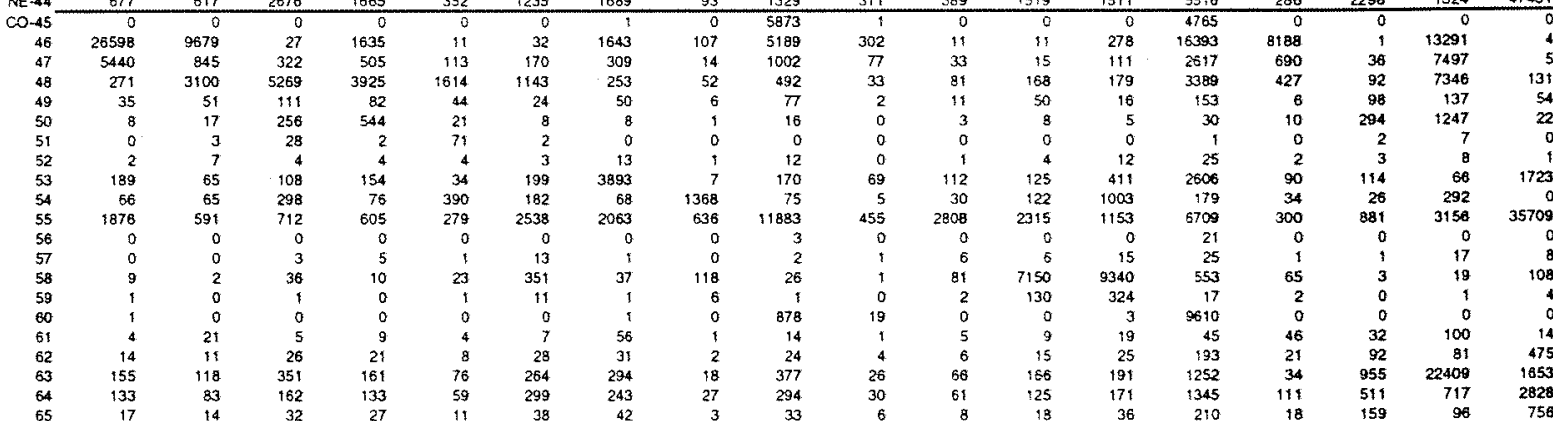

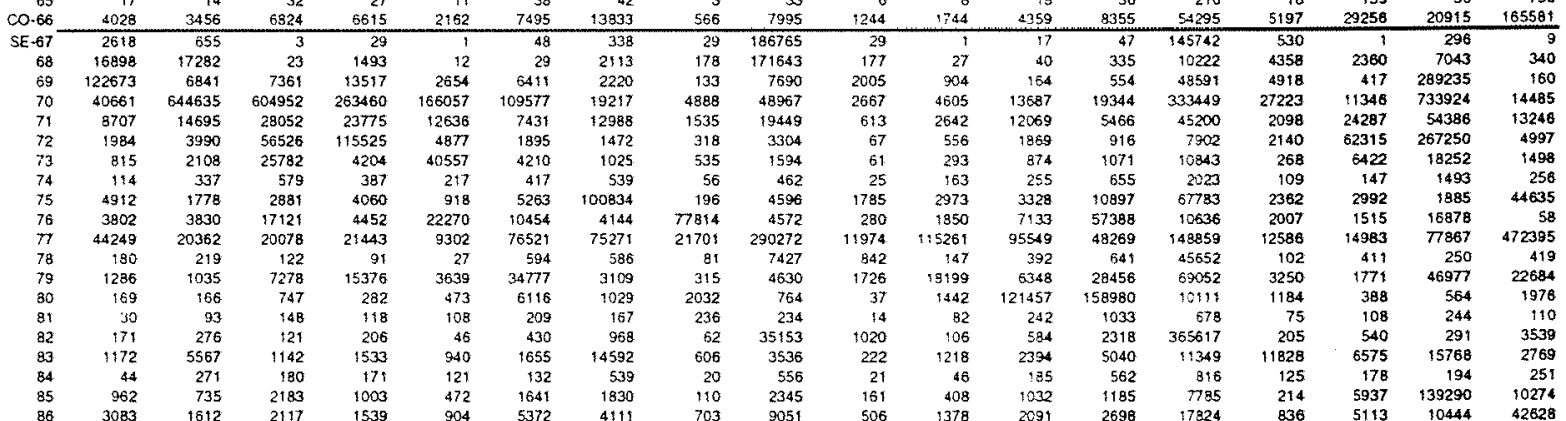

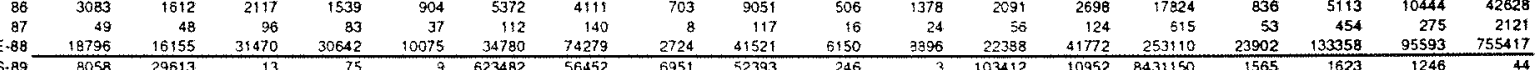

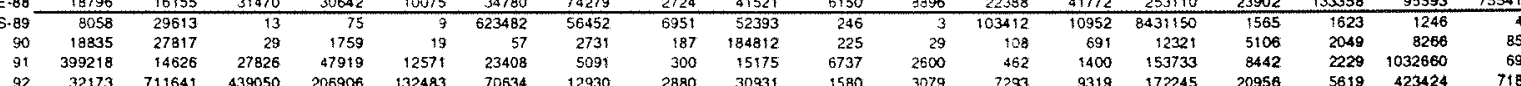

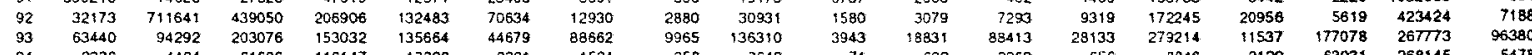

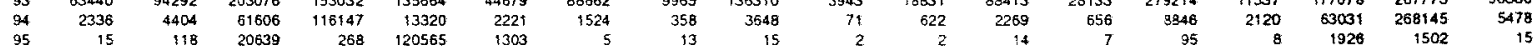


Mocànica

Material de Transponte

Colujose, Papol or Grall

ind. da Borracha

Fammacétece

Indict Ténil

Vertuanio Calcados

Prod. Alimentares

Industnas Diversas
Slup . Com..

Construx ja Ch

Comircio

Transportas

Agropecuária

Minoraçáo

Motaturgan

Mocanica
Matarial Elotrico

Material de Transporte

Celubose, Papal a Grá

Ind da Borrach
Qulmica

Farmacolixic

Ind Texti

Vestuário - Calçados Prod. Alimentares Indup. Com...

Construcso Civil

Comdrcio

Servicas

Agropecuári

Minarais náo Matálicos Metalury

Matanica

Material de Transpone

Caluibse. Papel o Gr

ind da Borracha

Quimica

Plasticos
Ind. Toxdi

Vostuério Calçados

Prod. Allmortatas

SiUP Com.

Comercio

Transporios

Agropecuán

Mineracis nao Metálicas

Metakurge

Macantica

Material de Transporte

Maderra o Mobiliario

Ind. da Borracha

Farmacturea

Piásticos
Ind. Texti

Vastuano Calçactos

Prod. Alimamares

SIUP COm.

Construcato C
Combrco

riansportes

Sarvicos

Mineráas náo Metalicos

Metalurgla

Matenai Elotitroo

Material de I tansporte

Colubse. Papal Gíá.

Ind da Borracha

Famaceutica

Plásticos

Pod. Alknemares

SIUP Com..

Comerios

Transportes

importacios
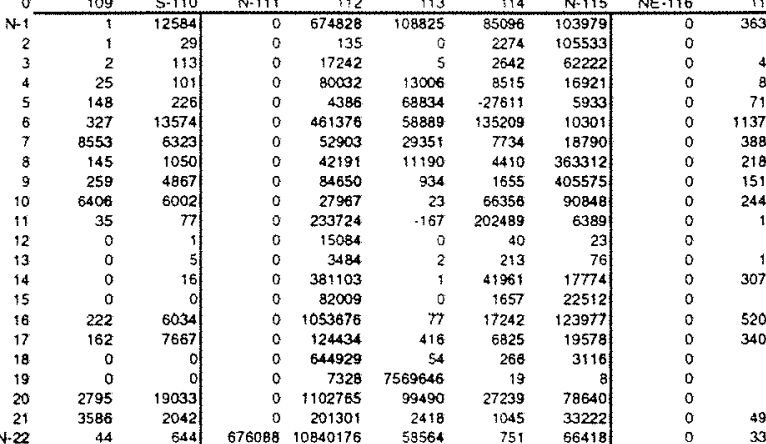


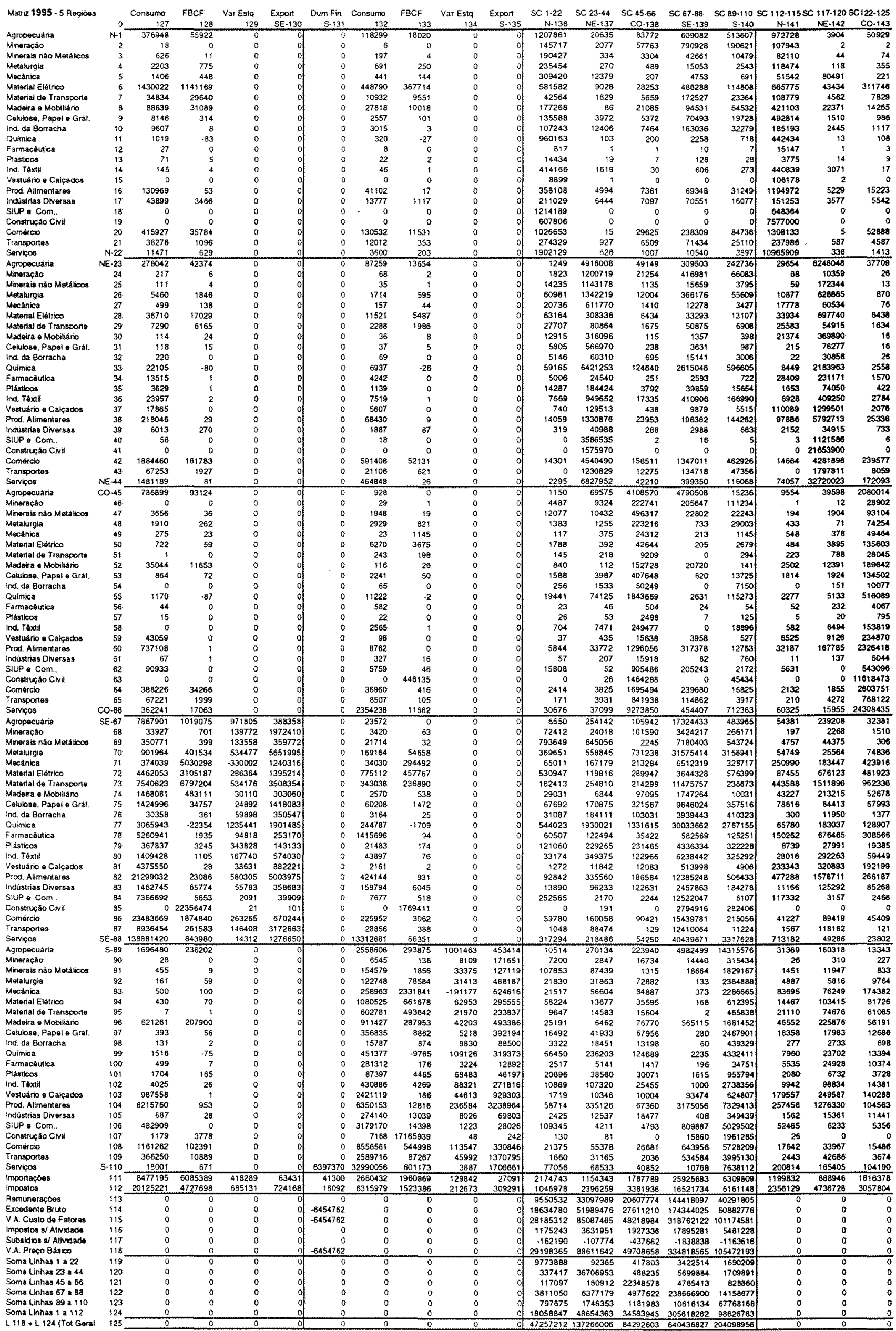


Matriz 1995 - 5 Regices SC 127-130SC 132-135 SC 136-140 SC 141-145 Yotal Geral Agropecuatia Mineraçás nào Motalicos Motalurgia

Mocánica

Matertal Elótrico

Maiznal de Transporto

Calubses, Papel Grát

ind. da Borrachs

Quimica

Farmacoututica
Plásticos

ind. Téxtis

Vestuatio a Calçados

Prod. Alimentares

Indigtrias Over:

Constructo Clvi

Comércio.

Transportes

Servicos

Agropecuária

Miroraç̆to
Minerais năo Motalico

Metalurgia

Mataftal Efétrico

Mataria de Transoon

Calutosa, Papel o Grat.

Ind. da Borracha

Química

Farmacoutica

Plástcos

Vestuáric - Calçados

Prod. Alimentares

Indusitrias Dhersa

Construç की Civi

Combrcio

Transportes

Senvicos

Agropecuán

Mineraias náo Metáticos

Meralurie

Mecanica

Matorial Eletrico

Material do Transpono

Colutose, Papei o Grá

Ind. da Borracha

Quimica

Farmacautica

Plásticos

ind. Toxtil

Vestuánio Całçacos

Prod. Alimantaras

SIUP Com.

Construḉ CNH

Comercio

Transporte

Agropecuátia

Mtrarais náo Meíalicos

Metalurgia

Mecanica

Matorial Elátrico

Material de Transporte

Madeira o Mobiliádio

Cotulose, Papel Grál.

Ind. da Borracha

Farmacautica

Plásticos

Vestuáric o Całçados

Prod. Alimentares

Indüstrias Diversas

SUP Com..

Construcão Civil

Comercio

Transportes

Servicos

Minerą̧ắo

Minerais não Metálicas

Metalurgia

Mecantica

Malerial Elattrico

Material de Transport

Celulose. Papel o Grát.

Ind da Borrach

Oulmica

Plamacistica

Ind Toxil

Vestuário Calçados

Prod. Alimentaras

Industrias Divers

SIUP a Com.

Constructio

Comercio

Servicos

imporaçoos

impostos

Remuneracóas

V.A. Custo de fatores

impostos s/ Aividado

Subsidiog a/ Ativid ado

V.A. Preço Básico

Soma Linhas 1 a 22

Soma Linhas 23 a 44

Soma Linhas 67 a

Some Linhas 89 a 110

Soma Linnas 1 a 112

$L 118+L 324$ (Tot Gera

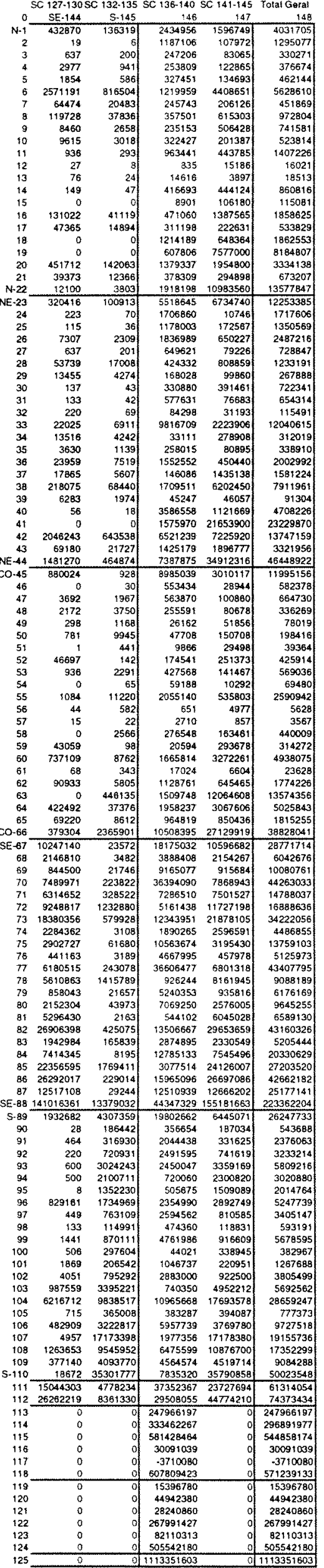

